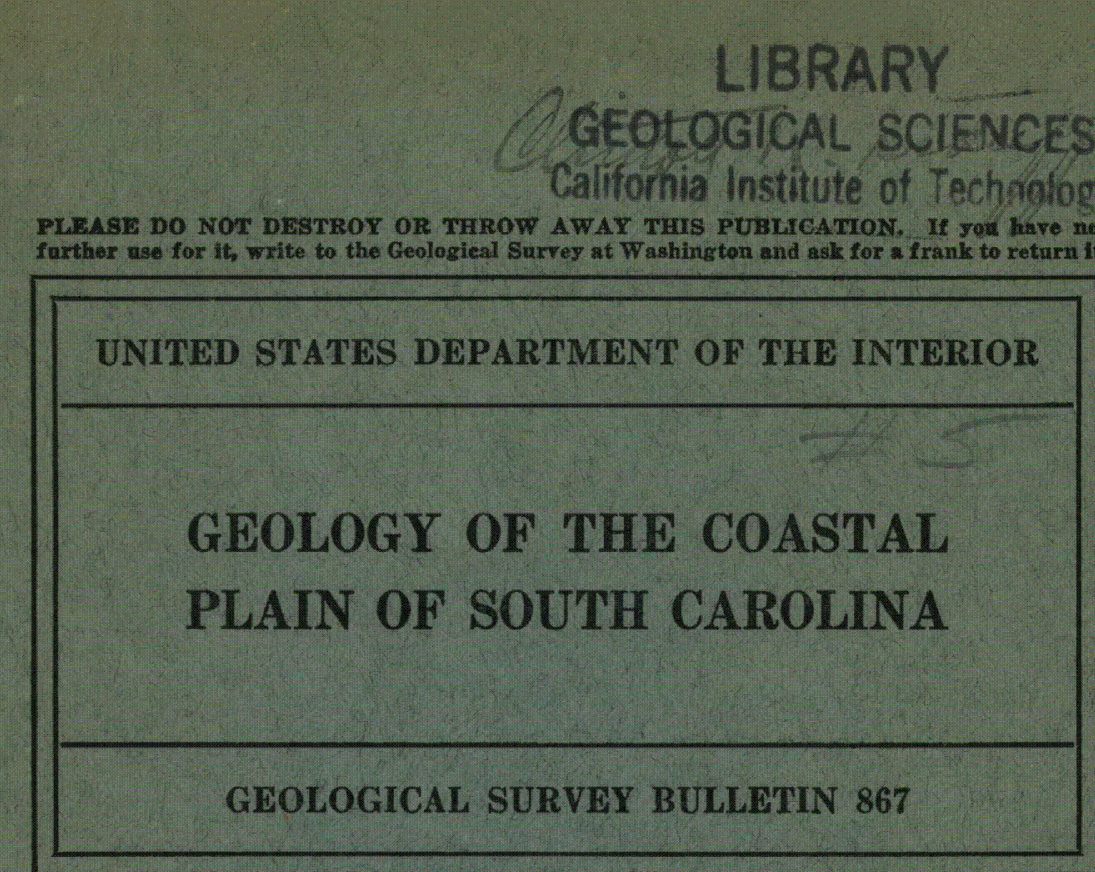


Please do not destroy or throw away this publication. If you have no further use for it, write to the Geological Survey at Washington and ask for a frank to return it

\section{UNITED STATES DEPARTMENT OF THE INTERIOR \\ Harold L. Ickes, Secretary \\ GEOLOGICAL SURVEY \\ W. C. Mendenhall, Director}

\section{Bulletin 867}

\section{GEOLOGY OF THE \\ COASTAL PLAIN OF SOUTH CAROLINA}

BY

C. WYTHE COOKE

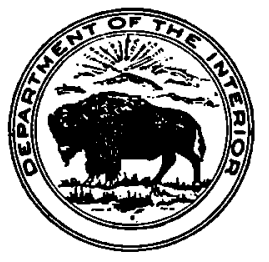

UNITED STATES

GOVERNMENT PRINTING OFFICE

WASHINGTON : 1936

For sale by the Superintendent of Documents, Washington, D. C. - - - - - Price 60 cents 



\section{CONTENTS}

Abstract
Geographic provinces
Geographic divisions of the Coastal Plain of South Carolina.
Coastal terraces
Pamlico terrace
Penhot terrace
Wicomico terrace.
Sunderland terrace.
Coharie terrace
Brandywine terrace
Aiken Plateau
Richland red hills.
High Hills of Santee.
Congaree sand hills.

Drainage

Principal streams... . . . .

Development of the drainage... 13

Stratigraphy

Formations included......... 14

Upper Cretaceous series

General features

Tuscaloosa formation............. 17

Black Creek formation......

Peedee formation

Eocene series

Correlation.......... 39

Black Mingo formation. 41

McBean formation .

Deposits of Jackson age

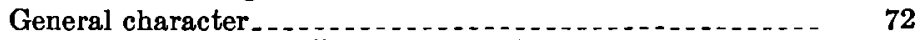

History of the names "Santee" and "Cooper"

Santee limestone............... 75

Cooper marl

Barnwell sand . . . . . . .

Oligocene series_...

Flint River formation

Miocene series..... 99

General features .

Hawthorn formation

Raysor marl

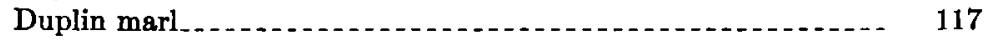

Pliocene series

General features.

Waccamaw formation 
Stratigraphy-Continued. Page

Pleistocene series........... 130

Fluctuations of sea level _ . . .

Marine formations . . . . . . .

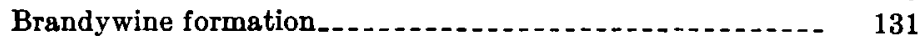

Coharie formation

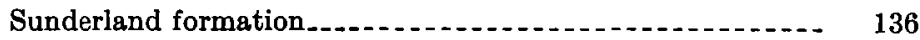

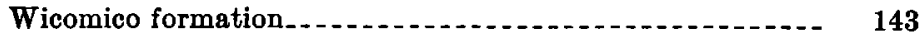

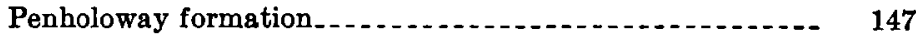

Talbot formation......... 148

Pamlico formation. . .

Geologic history

Structure._.

Mineral resources

Metals_...

Nonmetals....... 159

Phosphate rock .

Limestone and calcareous marl ............... 159

Clay

Sand and gravel

Mineral fuels_............. 161

Ground water.

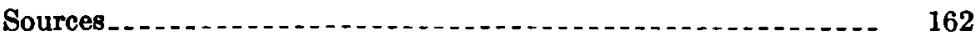

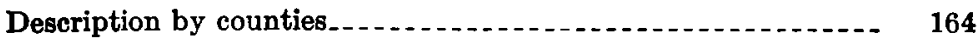

Aiken County . .

Allendale County

Bamberg County

Barnwell County

Beaufort County

Berkeley County

Calhoun County.............. 169

Charleston County

Chesterfield County

Clarendon County $\ldots \ldots \ldots$

Colleton County

Darlington County

Dillon County

Dorchester County.......... 176

Florence County .................. 177

Georgetown County......... 179

Hampton County

Horry County

Jasper County

Kershaw County

Lee County . .

Lexington County

Marion County

Marlboro County

Orangeburg County .......... 185

Richland County

Sumter County

Williamsburg County

Index 


\section{ILLUSTRATIONS}

Plate 1. Map showing the distribution of the Pleistocene terraces and the original extent of the Pleistocene formations in South Carolina ... . . . . . In pocket

2. Geologic map of the Coastal Plain of South Carolina....... In pocket

3. $A, \mathrm{~A}$ sand dune on Folly Island; $B$, Stumps on the beach at Folly Island; $C$, Encroachment of the sea on Folly Island..--

4. Land and sea in Pamlico time 10

5. Land and sea in Talbot time. 10

6. Land and sea in Penholoway time... 10

7. Land and sea in Wicomico time.......................... 10

8. Land and sea in Sunderland time..... 10

9. Land and sea in Coharie time..... 10

10. Land and sea in Brandywine time

11. $A$, Erosion in the Aiken Plateau exposing the Upper Cretaceous Tuscaloosa formation on upper Aiken-Graniteville road 4 miles west of Aiken; $B$, Tuscaloosa formation 2 miles northeast of Middendorf

12. A, Tuscaloosa formation 1 mile north of Langley; $B$, Mars Bluff, Pee Dee River.............

13. $A$, Tuscaloosa-Black Creek (?) contact 1 mile west of Wedgefield; $B$, Dewitts Bluff, Pee Dee River...............

14. A, Contact between the Black Mingo formation and the McBean formation near Bates Mill, Calhoun County; $B$, Marl pit at Lambs..........

15. $A$, Barnwell sand in railroad cut at Aiken; $B$, Sandstone of Barnwell age on the Dibble farm $5 \frac{1}{2}$ miles southeast of Aiken . . . . . .

16. A, Barnwell sand near Bethel Church, Lexington County; $B$, Unconformity between the Hawthorn formation ( $\uparrow$ Marks Head marl) and the Duplin marl above Enochs wood landing, Savannah River, 67\% miles above Savannah..-

17. Mosaic of aerial photographs of part of Horry County between

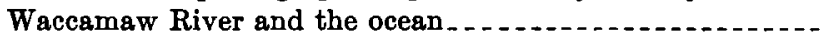

18. Map showing the approximate original distribution of phosphate deposits in South Carolina...

Fradre 1. Geographic divisions of the Coastal Plain of South Carolina.- 4

2. Ideal profile across the coastal terraces... 6 



\title{
GEOLOGY OF THE COASTAL PLAIN OF SOUTH CAROLINA
}

\author{
By C. Wythe Cooke
}

\begin{abstract}
ABBTRACT
The Coastal Plain of South Carolina extends from the Atlantic Ocean inland a distance ranging from 120 to 150 miles to the Fall Line, where it adjoins the Piedmont province. It includes an area of more than 20,000 square miles, or nearly two-thirds of the State, whose total area is 30,981 square miles, of which 494 square miles is water.

The geographic divisions of the Coastal Plain are the marine coastal terraces, or "low country", which stand less than 270 feet above sea level, and the Aiken Plateau, the High Hills of Santee, the Richland red hills, and the Congaree sand hills. Few places in the Coastal Plain are as high as 600 feet above sea level. The coastal terraces together have an area more than twice as great as all the rest of the Coastal Plain. The landward limit of each terrace is defined by the level shore line at which the sea and its estuaries stood when the terrace was under water. The seaward limit is the shore line of the next lower terrace. The names of the terraces and the approximate present altitude of the shore line of each are as follows: Pamlico, 25 feet; Talbot, 42 feet; Penholoway, 70 feet; Wicomico, 100 feet; Sunderland, 170 feet; Coharie, 215 feet; Brandywine, 270 feet. The present shore line, which bounds the Recent terrace, has a total length of 1,241 miles, including 281 miles of mainland and 960 miles around islands.
\end{abstract}

The Coastal Plain is drained by three large through-flowing rivers-the Pee Dee, the Santee, and the Savannah-and by many smaller streams. The drainage pattern of the uplands was well established before the beginning of Pleistocene time; that of the coastal terraces is more youthful.

The Coastal Plain of South Carolina is underlain by sedimentary deposits ranging in age from Upper Cretaceous to Recent, which lie unconformably on ancient crystalline rocks. There are three Upper Cretaceous formations-the Tuscaloosa formation, composed chiefly of light-colored sand and clay; the Black Creek formation, consisting in its lower part of dark-gray to black leaf-bearing laminated sand and clay and in its upper part of the sandy Snow Hill marl member, which contains marine fossils; and the Peedee formation, composed chiefly of gray sand and marl-stone.

The Eocene series is represented by the Black Mingo formation, of Wilcox age; the McBean formation, of Lisbon (Claiborne) age; and the Santee limestone, the Cooper marl, and the Barnwell sand, all of Jackson age, the last apparently equivalent to both Santee and Cooper. All the Eocene formations contain marine shells.

The only representative of the Oligocene series is the Flint River formation, which occupies a small area in Allendale County but extends westward across Georgia and into southeastern Alabama and northern Florida. 
The Miocene series includes the phosphatic Hawthorn formation, whose typical occurrence is in Florida; the Raysor marl, a shell bed that is in part equivalent to the lower part of the Yorktown formation of Virginia and to the lower part of the Choctawhatchee formation of Florida; and remnants of the Duplin marl, whose type locality is in North Carolina.

The Pliocene series is represented by the Waccamaw formation, composed chiefly of marine shell beds, and by high-level terrace deposits.

The seven Pleistocene formations have the same names as the Pleistocene terraces and are limited by the same shore lines. They consist chiefly of sand, but the younger ones contain clay and marine shells.

The geologic history of South Carolina records many advances and retreats of the sea during which sediments were deposited and planed off time and again. Many of the formations that were once continuous now persist only as small remnants. The shiftings of the shore line during Pleistocene time are regarded by the writer as due partly to glacial control of sea level.

The dominant structural feature of the Coastal Plain of the Carolinas is the "Great Carolina Ridge", whose axis lies near and parallel to the boundary between North and South Carolina. The downwarp of the region southwest of it during late Eocene time caused the Jackson sea to transgress across older formations and to flood the borders of the Piedmont in Georgia. Upon the beveled surface of the ridge lie thin patches of nearly borizontal Miocene and Pliocene shell beds and more extensive sheets of Pleistocene terrace deposits.

Enrichment of the phosphatic marl or limestone of the Miocene Hawthorn formation gave rise to valuable deposits of phosphate rock in the coastal region of South Carolina. The principal deposits of limestone and marl are in the Santee limestone and the Cooper marl, both of which are available in large quantity. Valuable deposits of kaolin in the Tuscaloosa formation are worked in several counties; the Barnwell sand contains some fuller's earth; and there are extensive deposits of clay suitable for making brick and tile in terraces along the principal rivers. Sand and gravel are widely distributed.

Most of the geologic formations of the Coastal Plain contain considerable water. The Tuscaloosa formation yields great quantities of very pure water. Water from the Black Creek and Peedee formations is likely to contain considerable soda. The Cooper marl and the Santee limestone yield hard water. Many wells in the low country overflow, and some of them flow strongly.

\section{PHYSICAX GEOGRAPHY}

\section{GEOGRAPHIC PROVINCFS}

The State of South Carolina occupies parts of three geographic provinces. The northwestern edge lies within the Blue Ridge province; the part extending from the Blue Ridge to the Fall Line is in the Piedmont province; and the remainder, between the Fall Line and the sea, forms part of the Coastal Plain. This report deals only with the Coastal Plain.

Most of the deposits of the Coastal Plain are unconsolidated and soft or soluble and hence are more easily eroded than the granites, gneisses, and schists that underlie the adjoining Piedmont. The edge of the Piedmont bordering the Coastal Plain is therefore characterized by a series of rapids or falls (whence the term "Fall Line") where the 


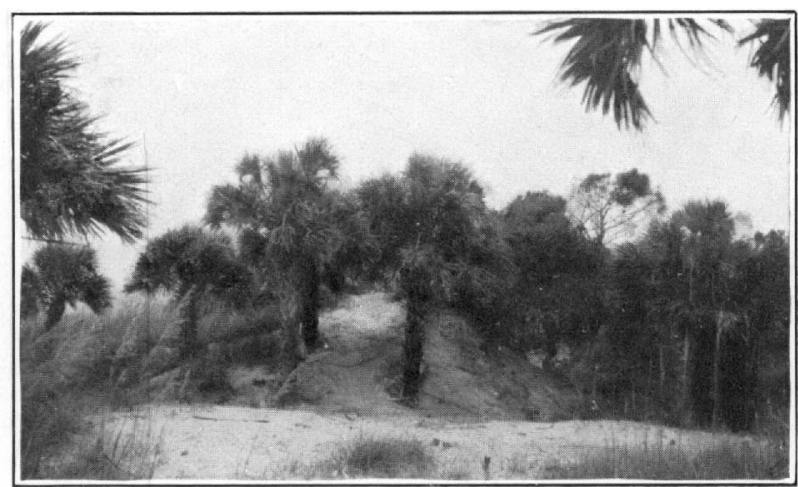

A. A SAND DUNE ON FOILY ISIAND.

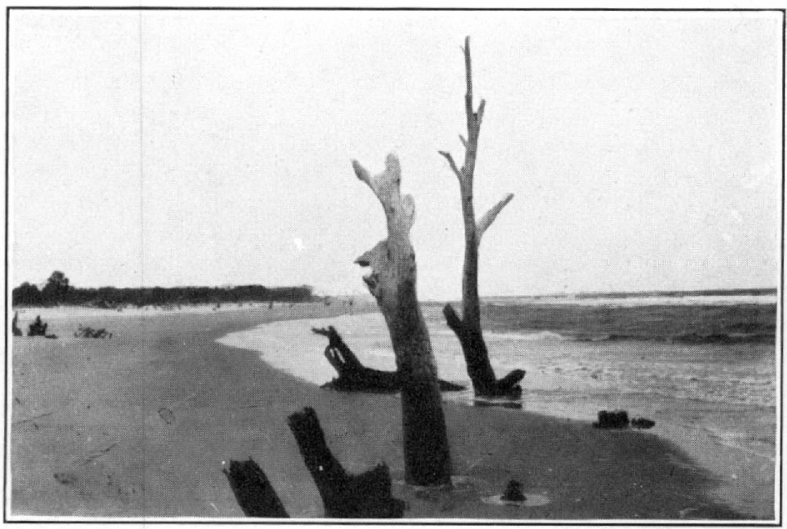

H. STUMPS ON THE HEACH ON FOLIY ISLAND.

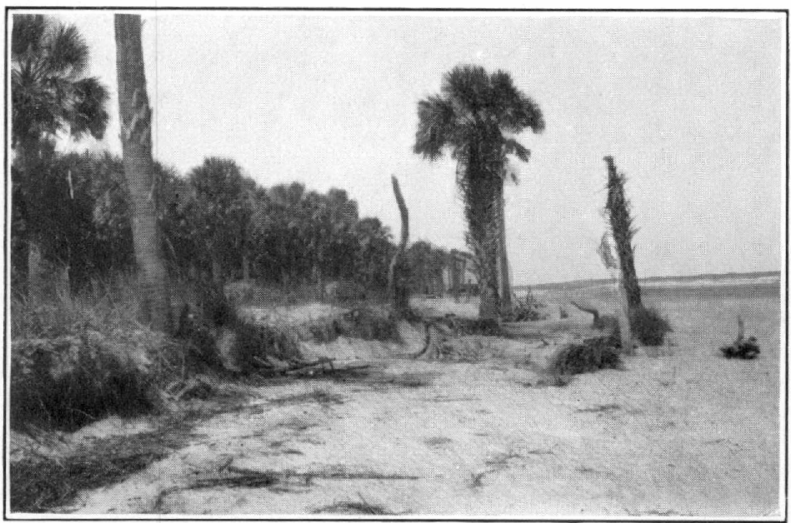

C. ENCHOACHMFNT OF THE SLA ON FOLLY ISLAND. 

streams tumble off the more resistant rocks of the Piedmont into the deeper valleys worn in the softer sediments of the Coastal Plain. In the interstream areas, however, there is no constant topographic contrast between the Coastal Plain and the Piedmont. At some places, as in Edgefield and Lexington Counties, the edge of the Coastal Plain has been worn back into a cuesta overlooking valleys in the Piedmont from which the sediments that now form the Coastal Plain have been eroded; elsewhere, particularly where the schists of the Piedmont are deeply weathered, there is little difference in relief.

The Coastal Plain and the Continental Shelf together form the Atlantic Plain, which extends from the edge of the Piedmont to the submerged edge of the continental mass, where there is an abrupt change from the comparatively shallow water on the Continental Shelf to the abysmal depths of the ocean. The boundary between the Coastal Plain and the Continental Shelf is the seashore, a very impermanent boundary, that shifts a little with every change of tide and even with changes in the direction of the wind. In the past the seashore has shifted repeatedly back and forth for a considerable distance across the Atlantic Plain, and all of the present Coastal Plain is covered by sediments that were laid down either in the sea or on land not far from the seashore. These wanderings of the seashore were due to two causes-first, tiltings or warpings of the land; second, fluctuations in the level of the sea. Movements of the land may have been the dominant cause of the earlier shiftings, but the shiftings on this part of the coast during Pleistocene time are regarded by the writer as largely the result of fluctuations in the level of the sea.

As a result of uneven warping of the land, the width of the Coastal Plain and the Continental Shelf is very irregular. North of New Jersey the eastern part of the continent has been downwarped to such an extent that the waves of the Bay of Maine beat upon the drowned rocky coast of New England, and the only remnants of a once extensive Coastal Plain remaining above water there are Cape Cod, Marthas Vineyard, Nantucket, Long Island, and a few smaller islands. In contrast with this is the southeastern part of the United States, where uplift along the axis of the Floridian Plateau has produced a Coastal Plain about 560 miles wide that extends to the edge of deep water. In South Carolina the Coastal Plain is 120 to 150 miles wide, and the adjoining Continental Shelf is nearly as wide.

\section{GEOGRAPHIC DIVISIONS OF THE COASTAL PLAIN OF BOUTH CAROLINA}

The Coastal Plain of South Carolina may be divided into five parts-the coastal terraces or "low country", the Aiken Plateau, the Richland red hills, the High Hills of Santee, and the Congaree sand 
hills. The boundaries of these divisions, very much generalized, are shown in figure 1.

Coastal Terraces

A discussion of the coastal terraces of South Carolina appropriately begins with a description of the present shore line, which forms their seaward boundary. From Cape Fear, in North Carolina, to the

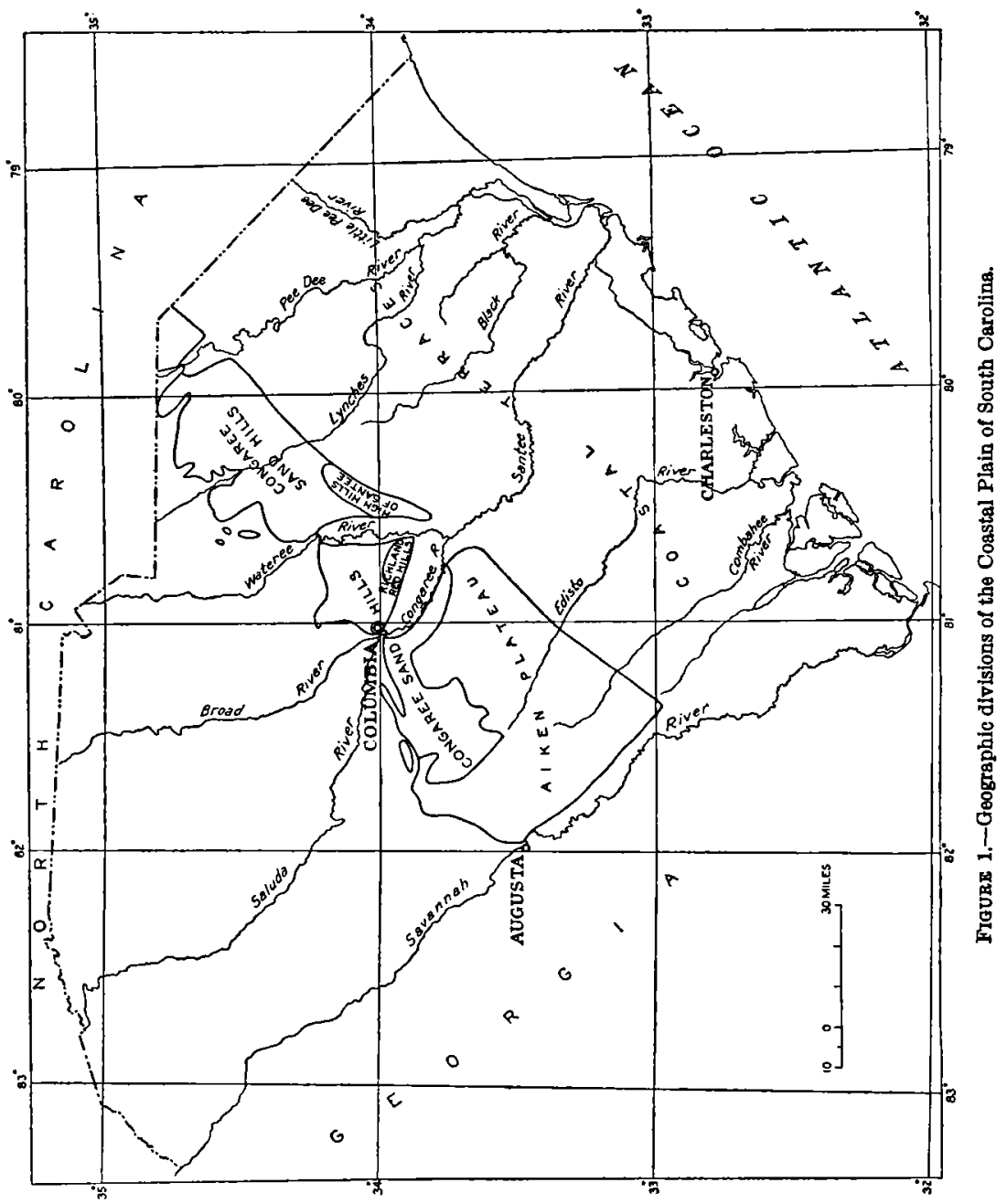

entrance to Winyah Bay, in South Carolina, the coast forms a great arc scooped out by the waves. The waves are still cutting back the shore in the middle part (near Myrtle Beach) and piling up the debris at each end, thus forming a smooth curve. The beach consists of fine sand with patches of coarser broken shells and is firm enough for automobiles to drive on it at low tide. The continuity of the beach is broken by several inlets, of which the most notable are Little River 
Inlet, Murrell Inlet, and North Inlet; North Inlet connects by tortuous channels around the head of North Island with Winyah Bay. From Winyah Bay, the outlet of the Waccamaw, Pee Dee, and Black Rivers, to Tybee Roads, at the mouth of the Savannah River, the coast line trends generally southwestward but is broken by many bays, rivers, and inlets that cut the land up into irregular "sea islands." The greatest irregularities are the mouths of the North and South Santee Rivers, Cape Romain (the end of the outermost of a jutting group of low islands), Bull Bay, Charleston Harbor (formed by the junction of the Cooper and Ashley Rivers), St. Helena Sound, Port Royal Sound, and Tybee Roads. The outermost edge of the sea islands is bordered at many places by firm sandy beaches, most of which have been hollowed by the waves into broad arcs. The most frequented beaches are those on the Isle of Palms, Sullivans Island, and Folly Island, all of which are connected by highways with Charleston. The Isle of Palms is notable for its sand dunes, which are advancing inland and burying a forest of palmettos. On Folly Island, also, the dunes are moving inland, and the sea appears to have recently encroached, for live-oak stumps stand on the beach with their bases covered at high tides-a location in which they could not have grown if they had not been formerly protected from the sea by a frirge of land. (See pl. 3.)

The coastal terraces occupy more than two-thirds of the Coastai Plain of South Carolina. They extend inland from the seashore a distance of 80 or 90 miles and even farther up the valleys of the larger rivers, where they reach the Piedmont. The inner margin is at places rather obscure, because there is little difference in relief between the highest terrace and the land behind it and because the higher parts of the terrace have been considerably eroded. The most conspicuous break lies at an altitude of about 215 feet above sea level, below which most of the country is remarkably flat, but a higher terrace, generally more dissected, extends beyond to an altitude of 270 feet. The 215 -foot line passes near Allendale, Orangeburg, Wedgefield, Bishopville, Hartsville, and McColl. The slope from this line to the sea averages 2.4 to 3 feet to the mile.

For many ages the area of the coastal terraces appears to have been part of a nearly level plain. Much of this plain was inundated by the sea several times during the Miocene epoch, as shown by large patches of middle and upper Miocene marine deposits that remain upon it. During the Pliocene epoch part of it was above water and much of the once continuous cover of Miocene deposits was eroded, but the widespread earth movements that ended the Pliocene resulted in drowning the coastal region as far inland as the landward margin of the present coastal terraces. The sea then probably stood about 270 feet higher than its present level. Since 


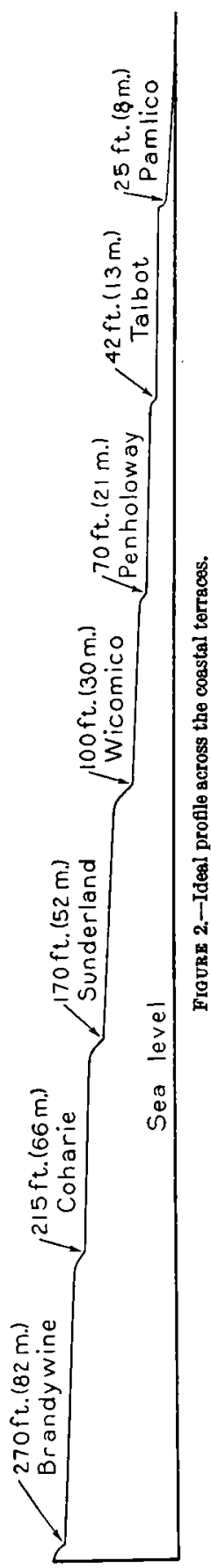

that time the sea has fallen and risen a number of times. With each lowering the plain has been drained and subjected to erosion; with each rise the part flooded has been to a great extent protected from erosion and coated with a layer of clay, sand, or gravel. At each temporary stand of the sea the waves cut back into the headlands and built bars across the mouths of bays, and when the sea withdrew to a lower level these wave-cut and wavebuilt features remained to mark the abandoned shore line.

Seven abandoned shore lines have been detected along the Atlantic coast of the United States. Evidence is accumulating that these shore lines encircle all the oceans, although their altitudes at some places have been changed by recent deformation. The part of the abandoned sea bottom between each shore line and the next lower one is treated as a separate terrace ${ }^{1}$ and given a distinctive name. The names of the seven coastal terraces and the approximate altitudes of their upper shore lines above present sea level are as follows: Pamlico, 25 feet; Talbot, 42 feet; Penholoway, 70 feet; Wicomico, 100 feet; Sunderland, 170 feet; Coharie, 215 feet; and Brandywine, 270 feet. The nearby bed of the ocean and of its estuaries would become a similar terrace, bounded by the present shore line, if the water were to retreat to a lower level. Tidal marshes and beaches are parts of this recent terrace, which is still in process of formation. ${ }^{2}$ The distribution of the coastal terraces in South Carolina is shown on plate 1 , and an ideal profile of these terraces is given in figure 2.

Pamlico terrace.-The Pamlico terrace, named from Pamlico Sound, in North Carolina, ${ }^{3}$ includes the land between the recent shore and an abandoned shore line 25 feet above sea level. It is well developed in Georgetown County, where it forms the plain that extends westward from Georgetown to the west edge of the swamp known as "Gapway Bay." It includes

:The term "terrace" is not altogether appropriate for the coastal terraces of South Carolina, because they are at many places very wide in proportion to the height of the scarps that separate them from the upland behind and the lowland in front of them. Some writers prefer the combination "terrace plain."

The shore line that forms the boundary between two terraces is that existing when the sea first reached its lower level, before the shore line was modified by the building of beaches and tidal flats-features that properly belong to the lower terrace, even though they may be built above sea level.

Itophenson, L. W., North Carolina Geol. and Econ. Survey, vol. 3, p. 286, 1912. 
the sea islands. Within its limits in the southern counties are several patches of higher land that were islands when the sea stood at the 25foot stage (pl.4). The landward boundary or shore line of the Pamlico terrace seems to be an arc in Georgetown County and perhaps also in Horry County, but as this area has not been mapped in detail the boundary has not been accurately traced. West of Berkeley County the boundary is very irregular but arcuate in general outline.

During Pamlico time a series of barrier beaches and islands was built by the winds and waves in the shoal water that occupied what is now the eastern part of Horry County. These ancient beaches and the swales between them are still plainly visible from an airplane (pl. 17). Between the islands can be seen an intricate system of abandoned inland waterways whose sandy shores show abundant evidence of the rounding work of waves and currents. The rounding of the shore lines had progressed so far before these bodies of water were converted into swamps (locally called "bays") that some of them had assumed an elliptical shape. The longer axes of the ellipses trend almost at right angles to the present seacoast, as if winds blowing from the ocean had set in motion and directed the waves and currents that shaped them. Because of their shape and uniform orientation, it has been suggested that these elliptical swamps partly surrounded by low sand ridges (here interpreted as bars, beaches, and dunes) might be scars made in the earth by the impact of a swarm of meteorites. ${ }^{4}$ This suggestion has considerable popular appeal but is supported by little factual evidence.

Talbot terrace.-The Talbot terrace, named from Talbot County, Md., ${ }^{5}$ ranges in altitude from about 25 feet to 42 feet above sea level. In the area covered by topographic maps (1933) which lies for the most part west of longitude $80^{\circ}$, the Talbot terrace is represented by many irregular patches that were islands in the Pamlico sea. At most places in this area the Pamlico tidal waters touched land that stood higher than the Talbot terrace. If the Talbot was originally a continuous plain in this region it was considerably eroded between Talbot and Pamlico time. In the unmapped area east of longitude $80^{\circ}$ the Talbot seems to be much more extensively developed than farther west, but details of the topography are lacking. The Talbot shore line, much generalized east of longitude $80^{\circ}$, is shown in plate 5 .

\footnotetext{
4 Melton, F. A., and Schriever, William, The Carolina "bays"-are they meteorite scars?: Jour. Geology, vol. 41, pp. 52-66, 1933; Scl. Am., vol. 149, pp. 106-107, 158-159, 188-189, 1933. Cooke, C. W., quoted in Meteoric origin of Carolina "bays" disputed: Science News Letter, vol. 23, p. 202, Apr. 1, 1933; Origin of the so-called meteorite scars of South Carolina: Washington Acad. Sci. Jour., vol. 23, pp. 569-570, 1933; Discussion of the origin of the supposed meteorite scars of South Carolina: Jour. Geology, vol. 42, pp. 8896, 1934. Muldrow, Edna, The comet that struck the Carolinas: Harpers Mag., Decomber 1933, pp. 83-89. Jobnson, D. W., Supposed meteorite scars of South Carolina [abstract]: Science, new ser., vol. 79, no. 2055, p. 461, May 18, 1934. Prouty, W. F., "Carolina bays" and elliptical lake basins: Jour. Geology, rol. 43, pp. $200-207,1935$.

- Shattuck, G. B., The Pleistocene problem of the North Atlentic Coastal Plain: Jobns Hopkins Unlv. Circ., wol. 20, p. 74, 1901; Am. Geologist, vol. 28, p. 104, 1901.
} 
Penholoway terrace.-The Penholoway terrace was named from a creek and a bay (swamp) in Brantley County, Ga. ${ }^{6}$ It extends from the Talbot shore line at about 42 feet to an altitude of about 70 feet above sea level. The shore line that marks its upper limit (pl. 6) differs conspicuously from the Pamlico and Recent shore lines in that it envelops few islands of the sea-island type. In the region where the more recent shore lines are so crooked the Penholoway shore runs almost straight. The Penholoway sea in South Carolina built many bars, barriers, and spits. Ridgeville and Summerville stand on features of this kind that enclosed a shallow body of water, just as Cape Canaveral in Florida shuts off the Indian River from the ocean. A low ridge running from Johnsonville almost to Kingstree appears to have been formerly a long barrier island that extended across the entrance of an irregular-shaped bay, but the topographic information available at the time of writing is inadequate for mapping it accurately. In the southern part of the State the Penholoway terrace is very narrow and at some places entirely absent, but north of Cottageville it widens and in Williamsburg County attains its maximum width of about 25 miles. The estuarine parts of the terrace extend up the valleys of the larger streams, reaching as far north as Marlboro on the Pee Dee and Allendale on the Savannah.

Wicomico terrace.- The Wicomico terrace, named from a river in Maryland, ${ }^{7}$ lies at an altitude of about 70 to 100 feet above sea level. The shore of the Wicomico sea (pl. 7) was very irregular and was evidently drowned. A chain of barrier islands built up by the sea 8 to 12 miles off shore protected much of the coast. In this respect the Wicomico coast was like the present coast of North Carolina in the vicinity of Cape Hatteras. The marine part of the Wicomico terrace in South Carolina ranges in width from about 8 miles to nearly 30 miles, and the estuarine parts extend up the river valleys for many miles-on the Pee Dee to Kollock, on the Wateree and Congaree to points 10 or 15 miles below Camden and Columbia, and on the Savannah within about 15 miles of Augusta.

Sunderland terrace.-The Sunderland terrace, named from a village in Maryland, ${ }^{8}$ extends from an altitude of about 100 feet to an abandoned shore line about 170 feet above sea level. In the area that has been mapped in detail the nearshore part of the terrace has been so modified by solution of rocks underground that the exact position of the shore line is not everywhere determinable, and in the unmapped areas the available topographic information is inadequate for accurate mapping. The shore appears to have been rather

- Cooke, C. W., Physical geography of Georgia: Georgia Geol. Survey Bull. 42, p. 24, 1925.

7 Shattuck, G. B., op. cit., Johns Bopkins Univ. Circ., vol. 20, p. 74, 1901; Am. Geologist, vol. 28, p. 103, 1901.

${ }^{3}$ Shattuck, G. B., op. cit., Johns Hopkins Univ. Circ., vol. 20, p. 74, 1901; Am. Geologist, vol. 28, p. 102, 1901. 
sinuous (pl. 8) but not so crooked as that of the Wicomico sea. No barrier islands have been detected. The width of the Sunderland terrace averages about 20 miles. Estuarine reentrants extend up all the large rivers to the Fall Line.

Coharie terrace.-The Coharie terrace, named from Great Coharie Creek, in North Carolina, ${ }^{9}$ lies between 170 and 215 feet above sea level and ranges in width from 1 or 2 miles in Allendale County to 15 miles or more in Darlington County, the variations depending chiefly on the sinuosities of its outer margin. The shore line of the Coharie sea (pl. 9) was somewhat straighter than that of any other Pleistocene stage of the sea with the possible exception of the Penholoway. The flat Coharie terrace contrasts markedly with the much-dissected terrace that lies back of it and that in places rises 40 or 50 feet above it.

Brandywine terrace.-The Brandywine terrace, named from a village in Maryland, ${ }^{10}$ is the highest known, the oldest, and the least preserved Pleistocene terrace in South Carolina. The limits of altitude assigned to it are 215 and 270 feet. Although the available topographic maps show many flats that slope gently downward from 270 feet and that are backed by scarps rising above that altitude, the country is so deeply dissected that it is generally impossible to assign with assurance any particular area to the Brandywine without field examination. In the area mapped in detail the shore of the Brandywine sea appears to have been very crooked, but northeast of the Santee River it was probably straighter. Its approximate location is shown in plate 10 .

\section{AIKEN PLATEAU}

The Aiken Plateau lies between the valleys of the Savannah and Congaree Rivers. It extends northwestward from the edge of the coastal terraces to the Piedmont Plateau in Edgefield and Saluda Counties and to the Congaree sand hills in eastern Aiken County and in Lexington and Calhoun Counties. Originally the Aiken Plateau was an even plain sloping gently seaward. In its present condition it has been greatly dissected, particularly in the northern part, where valleys more than 300 feet deep ramify through it (pl. $11, A)$. In the southern part the relief is much less.

The highest point in the Aiken Plateau shown on topographic maps is 660 feet above sea level, west of Trenton, in the Warrenville quadrangle. Near Aiken the plateau ranges from 550 to 500 feet above sea level; near Windsor it is about 400 feet, and at Blackville 300 feet. The slope between Trenton and Blackville is 8 feet to the mile toward the southeast.

\footnotetext{
- Stephenson, L. W., North Carolina Geol. and Econ. Survey, vol. 3, pl. 273, 1912.

10 Clark, W. B., The Brandywine formation of the Middle Atlantic Coastal Plain: Am. Jour. Sci., 4th ser., vol, 40 , p. $499,1915$.
} 
The less dissected parts of the Aiken Plateau are dotted with shallow undrained depressions that appear to be due to the removal of soluble beds underground. Many of them are probably the result of the solution of limestone or marl, although it has been suggested ${ }^{11}$ that they are due to the solution of iron and aluminum from sandy sediments by ground water. The Aiken Plateau is underlain chiefly by the Barnwell and McBean formations (Eocene), both of which contain calcareous beds. There are similar depressions in Georgia on the Louisville Plateau, which is separated from the Aiken Plateau only by the Savannah River and which also is underlain by the Barnwell sand.

\section{RICHLAND RED HILLS}

The Richland red hills occupy an area in the eastern part of Richland County about 12 miles long and about 4 miles wide. The hills are composed of hard red argillaceous sand of the Black Mingo formation. In this respect they resemble the High Hills of Santee, which lie on the opposite side of the Wateree River. The Richland red hills adjoin the estuarine extensions of the coastal terraces in the Congaree and Wateree Valleys. North and west of them lie the Congaree sand hills.

The Richland red hills stand higher than any of the adjacent surface, but they are not as high as the more distant parts of the Congaree sand hills. Unchecked readings with an aneroid barometer indicate that the tops of the red hills rise about 400 feet above sea level.

\section{HIGH HWLS OF GANTEE}

The High Hills of Santee extend for about 20 miles through the western part of Sumter County and the southwestern part of Lee County. Viewed from the east they rise as a low ridge above the gently sloping coastal terraces. From the Wateree Valley, west of them, they appear much higher and steeper. The highest summits are about 430 feet above sea level. They were described ${ }^{12}$ in 1802 as follows:

In this belt or middle country the hills of Santee arise, perhaps 200 feet above the lands around them. Their soil is a mixture of sand, clay, and gravel, producing woods of oak and hickory and a profusion of underwood. They are well calculated for the growth of all highland grain, indigo, and cotton, affording at the same time some of the most beautiful and healthy settlements of the State. From hence the eye may range over a distance of prospect, across the Wateree and Congaree Rivers on one side and Black River on the other; the swamps below appear like an immense shrubbery, and the far removed lands show themselves in an undulating line with the distant horizon.

Like the Richland red hills, the High Hills of Santee are composed of hard red argillaceous sand of the Black Mingo formation.

\footnotetext{
11 Smith, L. L., Solution depressions in sandy sediments of the Cosstal Plain in South Carolina: Jour. Geology, vol. 39, pp. 641-652, 1931.

12 Drayton, John, A view of South Carolins as respects her natural and civil concerns, p. 10, Charleston, 1802.
} 


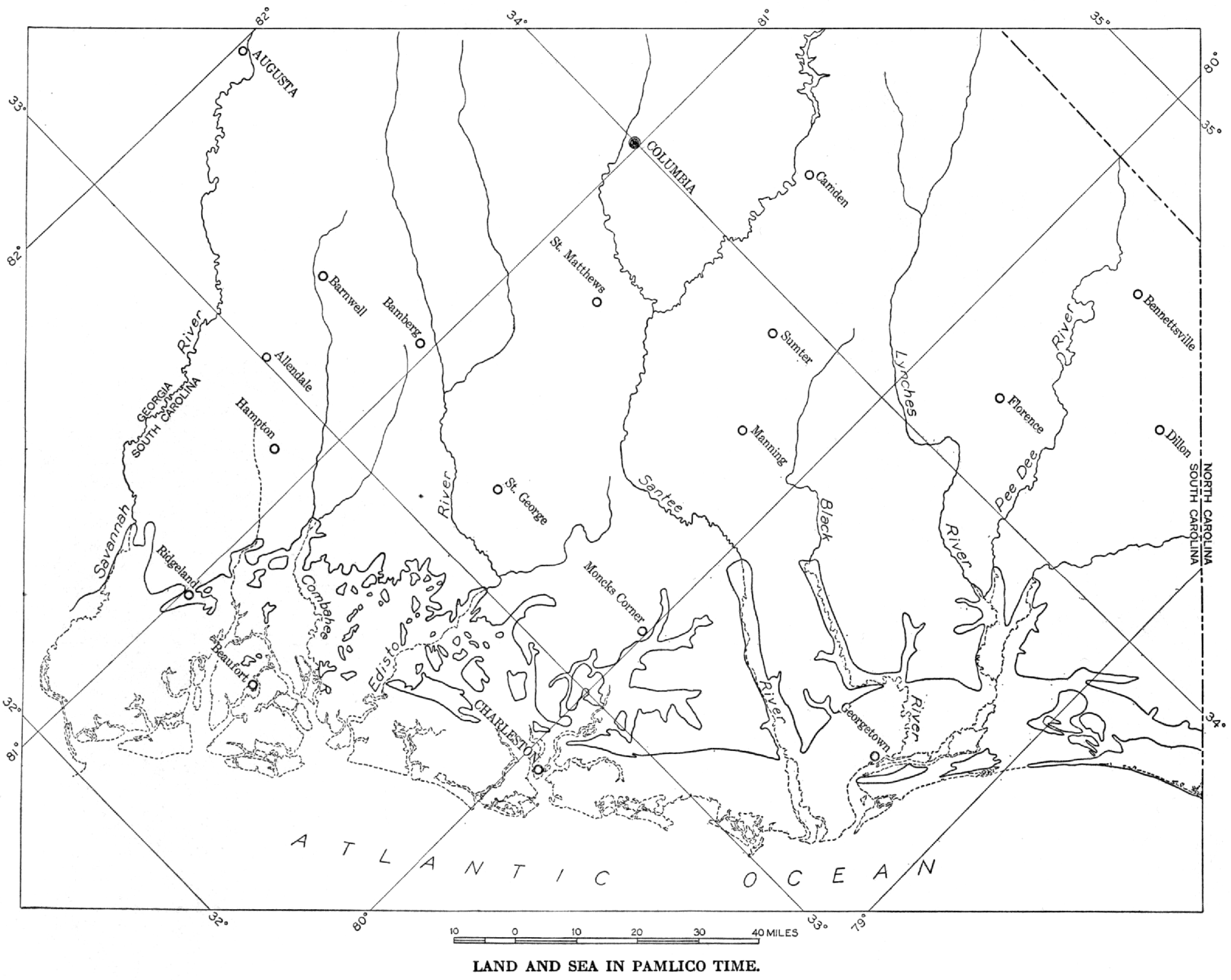





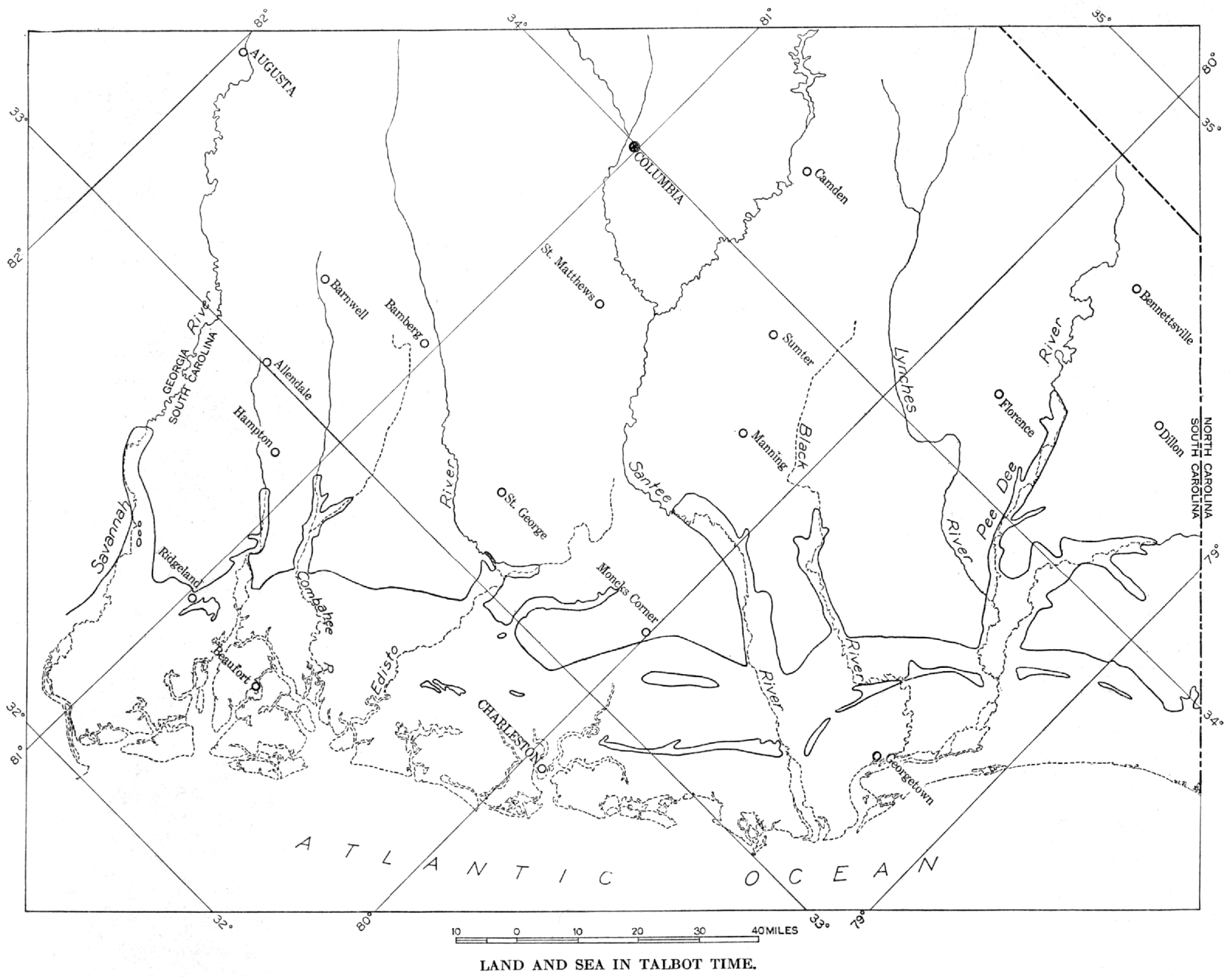





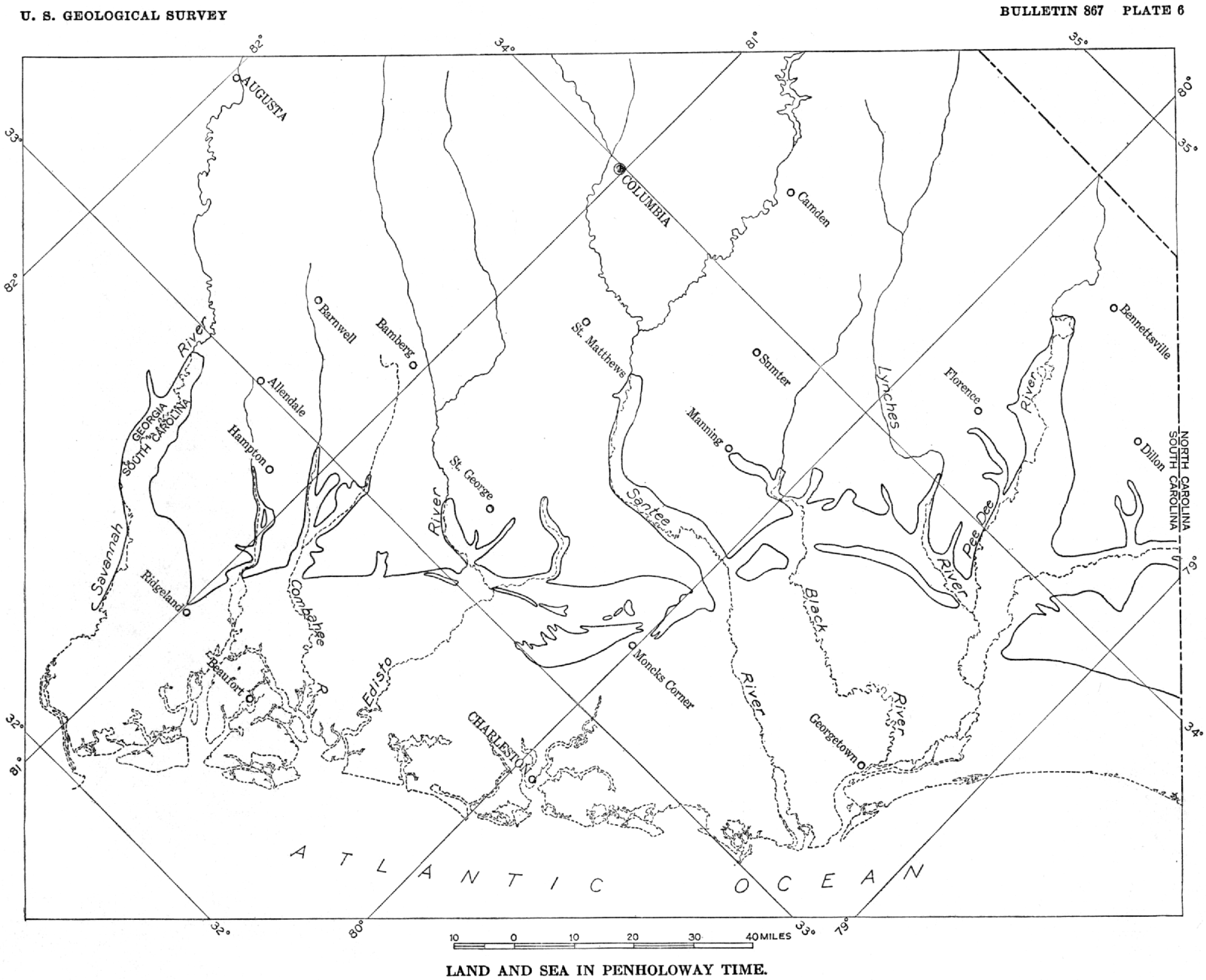





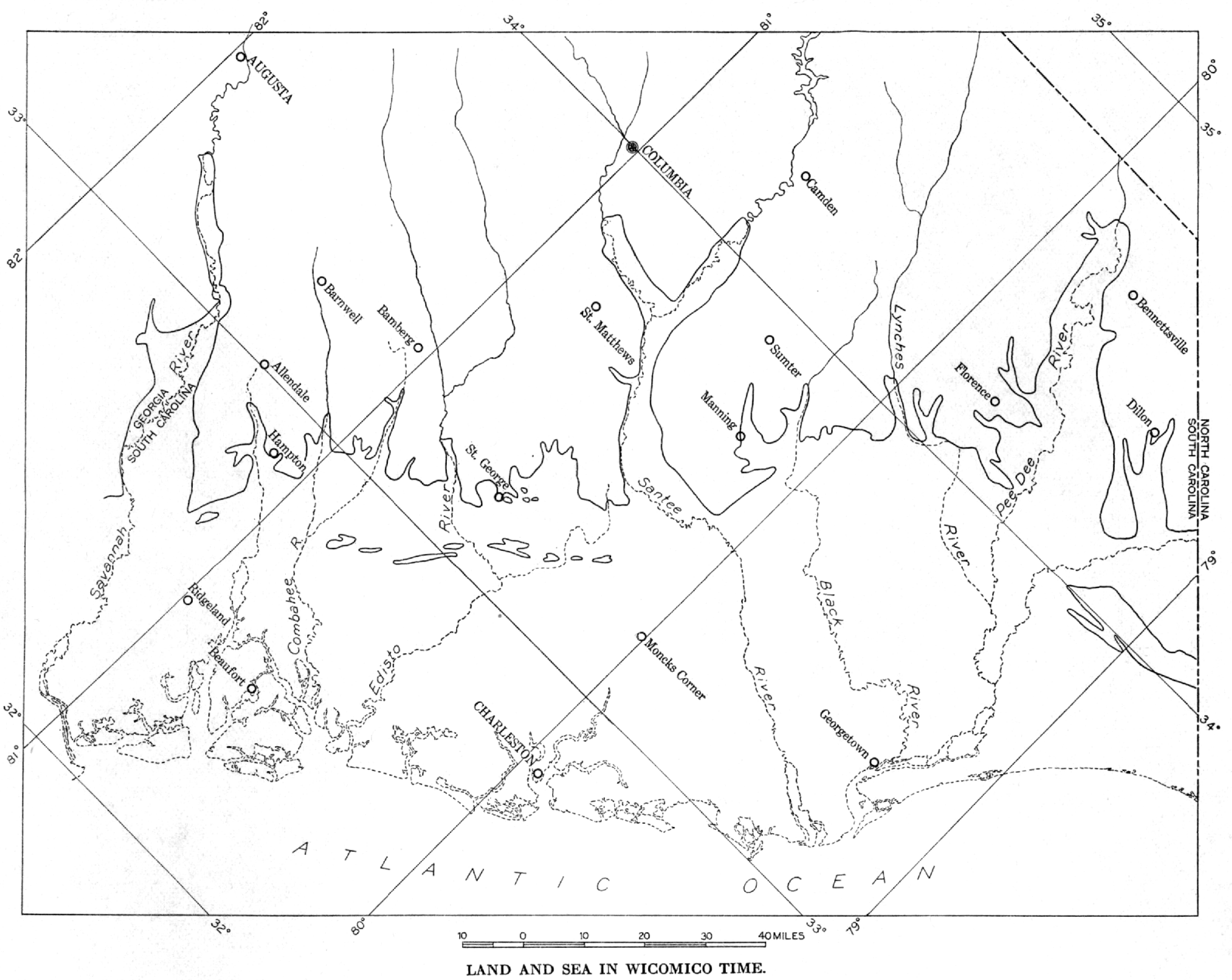





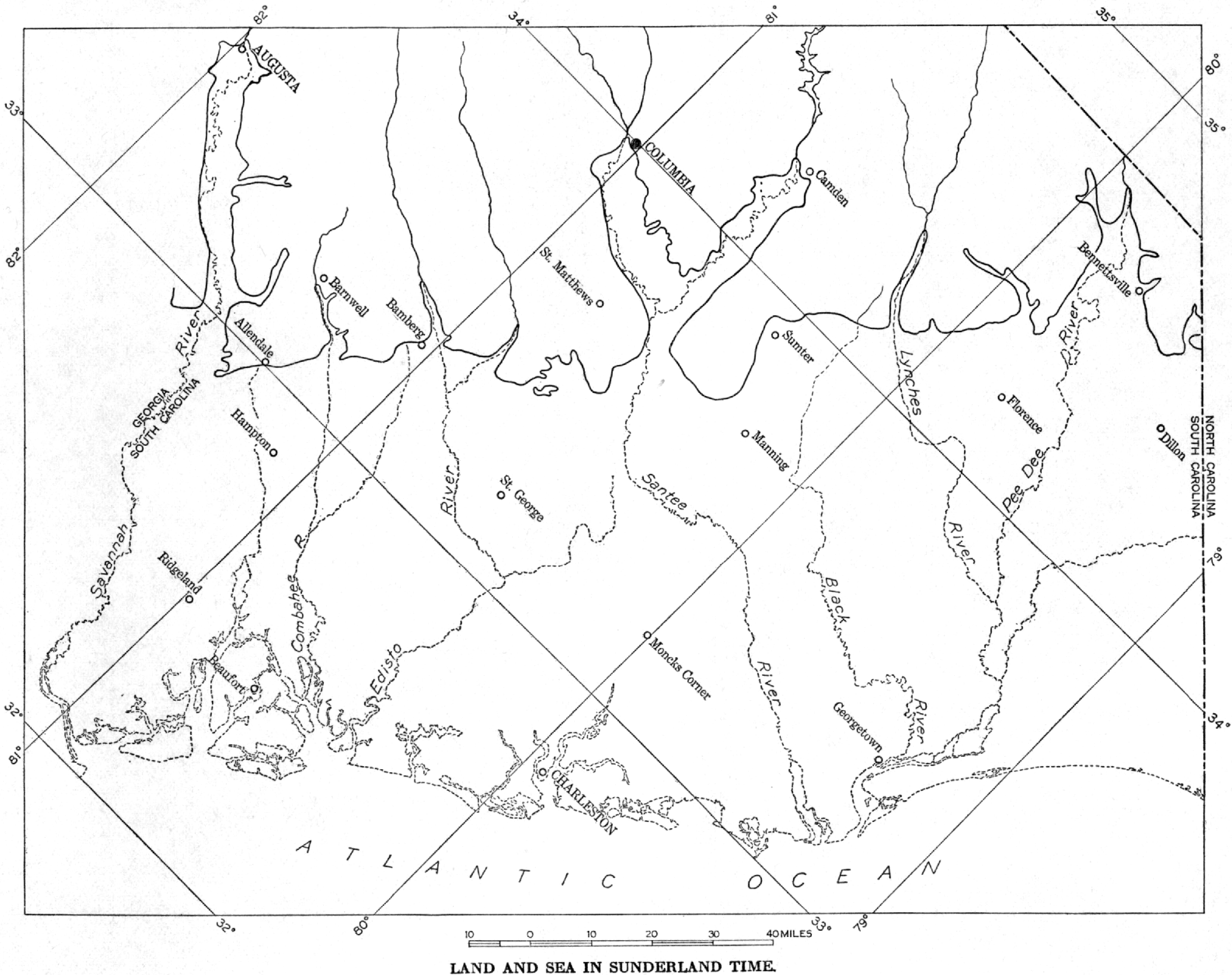



U. S. GEOLOGICAL SURVEY

BULLETIN 867 PLATE 9

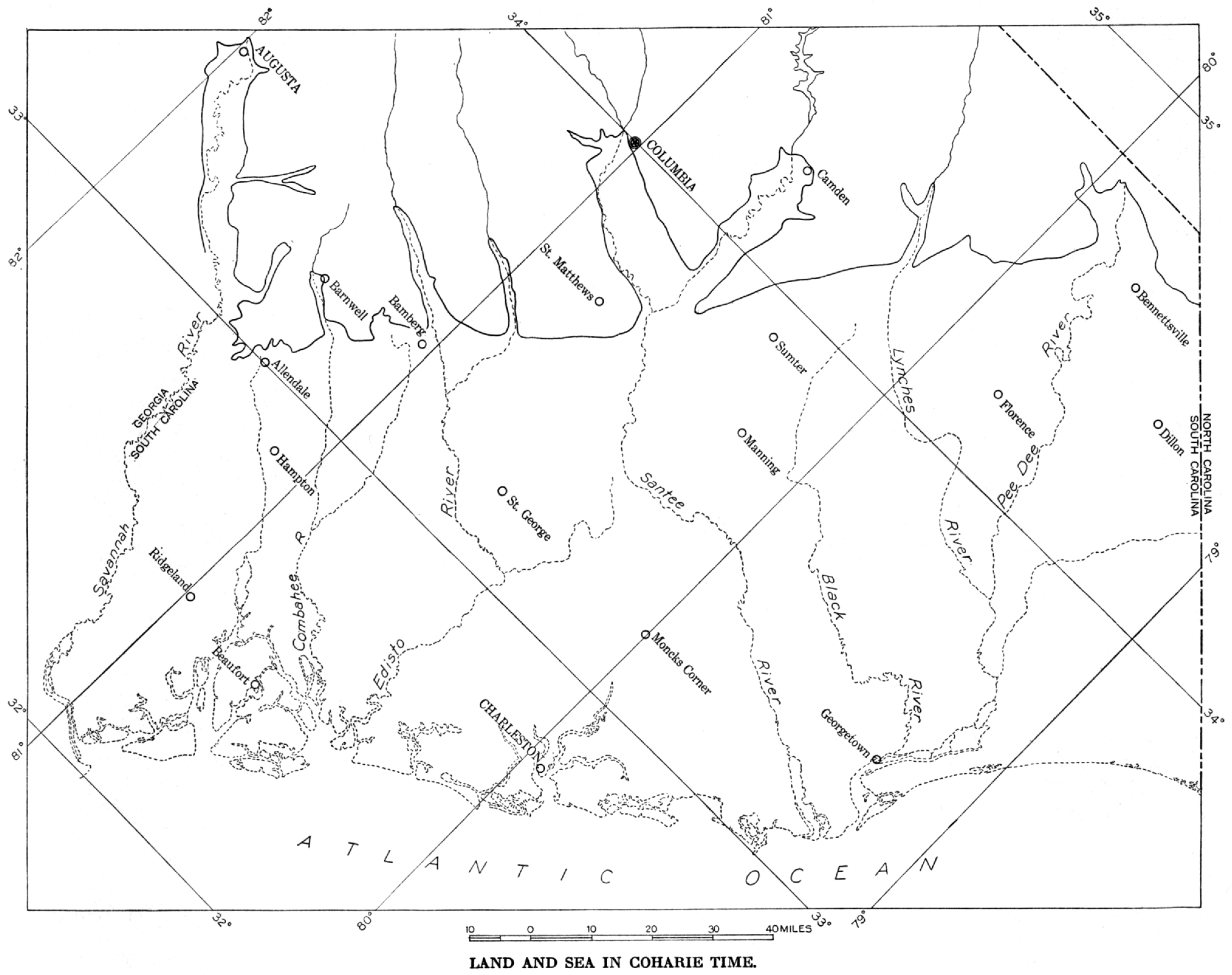



J. S. GEOLOGICAL SURVEY

BUlletin 867 PLATE 10

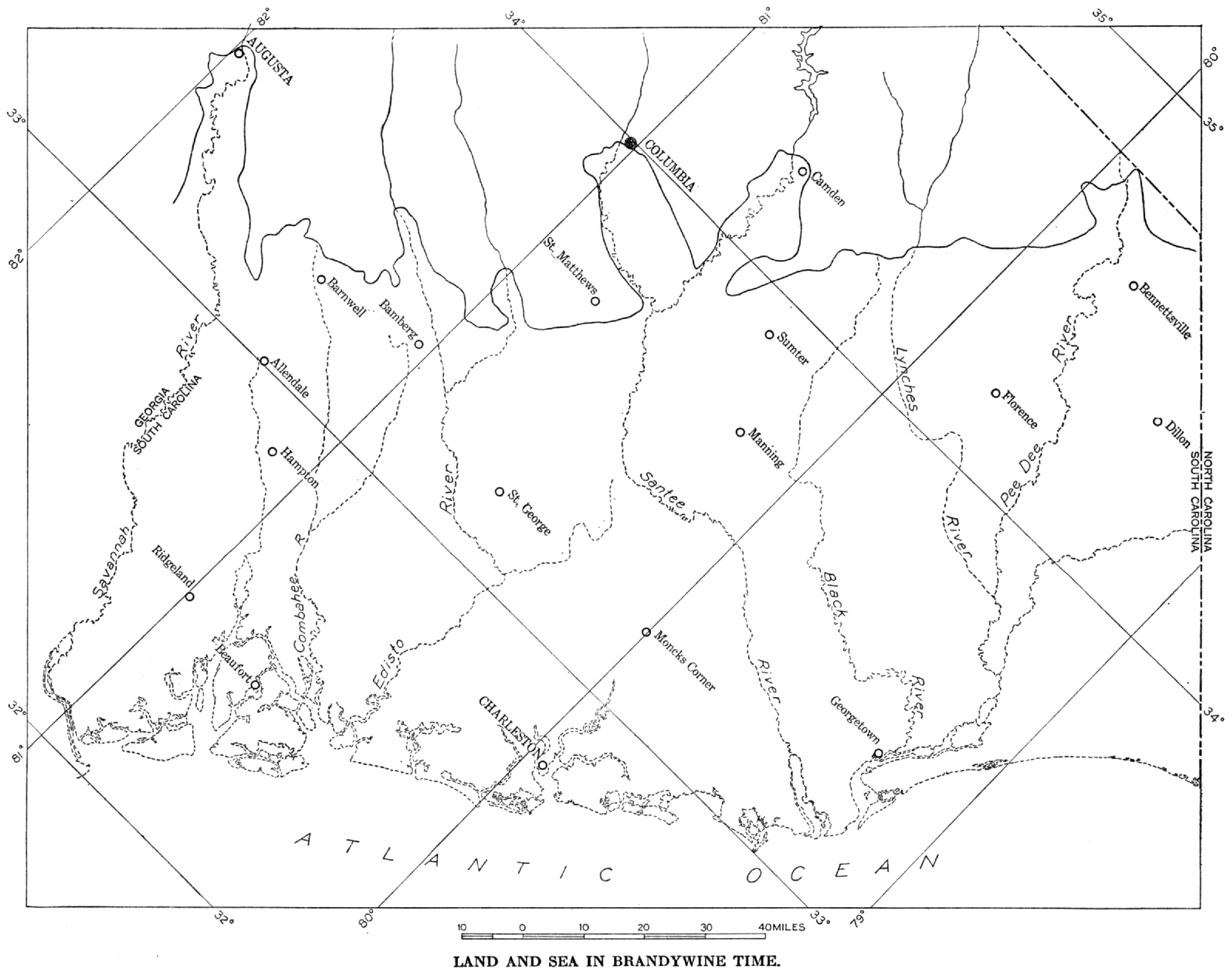



The Congaree sand hills extend from the Aiken Plateau in Aiken County into North Carolina. In South Carolina the sand hills are cut through by valleys in which are the terraces along the Congaree, Wateree, and Pee Dee Rivers. They adjoin the Piedmont Plateau on the northwest and the Aiken Plateau, the Richland red hills, the High Hills of Santee, and the coastal terraces on the southeast. They correspond approximately to the area in which the Upper Cretaceous Tuscaloosa formation is exposed.

Long gentle slopes and rounded summits are common in the more typical sand hills. Wind action seems to have had considerable effect in shaping the contour of the land in places where the soil consists of loose sand, such as Sand Mountain, in Lexington County, 9 miles south of Columbia. Where the soil is more compact the slopes are steeper and, as in the neighborhood of $\mathrm{McBee}$, lead upward to broad, gently sloping plains; such parts perhaps should not be classified as sand hills.

\section{DRAINAGE}

\section{PRINCHAL GTREAMs}

The streams that drain the Coastal plain of South Carolina are of two general types-through-flowing streams and streams that rise within the Coastal Plain. Much of the water in the throughflowing streams comes from the Piedmont and is nearly always stained yellow or red with mud. The streams that rise in the Coastal Plain are seldom muddy, but in most of them the water is stained brown or black by finely divided vegetable matter derived from the swamps through which they flow.

There are three large through-flowing rivers-the Pee Dee, the Santee, and the Savannah. The Pee Dee, which rises in North Carolina, enters the Coastal Plain a few miles above Cheraw and flows into the Atlantic Ocean through Winyah Bay. Its principal tributaries are the Lynches River, whose headwaters come from the Piedmont hills of Lancaster and Chesterfield Counties, and the Little Pee Dee, Waccamaw, and Black Rivers, all dark-colored Coastal Plain streams. The Santee is formed by the union of the Wateree River, which enters the Coastal Plain near Camden, and the Congaree, which heads at Columbia where two Piedmont rivers, the Saluda and the Broad, flow together. The Santee River system receives no large tributaries within the Coastal Plain, and its drainage basin there is very narrow. It enters the Atlantic between Winyah Bay and Cape Romain through two principal distributaries, the North Santee and South Santee Rivers. The Savannah River, which forms the boundary between South Carolina and Georgia, 
enters the Coastal Plain at Augusta and flows into Tybee Roads. It receives no large tributaries from the Coastal Plain of South Carolina, but several fairly large creeks enter it on the Georgia side. All these through-flowing rivers have rather deep, wide, flatbottomed valleys across which they meander through swamps.

The principal streams that head within the Coastal Plain east of the Pee Dee River are the Little Pee Dee River, the Lumber River, and the Waccamaw River. The Little Pee Dee flows southeastward (at right angles to the coast) until it meets the Lumber River, a larger stream which rises in North Carolina, then turns southwestward (parallel to the coast), continuing the direction of the Lumber River, until it reaches the valley of the Pee Dee, where it turns southeastward again and finally unites with the Pee Dee at the southern tip of Marion County. The valley of the Waccamaw River, which rises in North Carolina, also runs parallel to the coast as far as the head of Winyah Bay, at Georgetown. The main channel of the Waccamaw in Georgetown County is connected with the Pee Dee by many tortuous creeks.

The southwestward courses of the Lumber River, part of the Little Pee Dee, the Waccamaw, and many other streams that flow parallel to the coast, were probably determined by the position of lagoons, bays, or sounds that lay back of sand spits or barrier islands and that were drained by the lowering of sea level. The Little Pee Dee probably first assumed its southwestward course and was joined by the Lumber River when the sea retreated from the 100-foot (Wicomico) shore line, although its valley was submerged again during Penholoway and Talbot time. The Waccamaw apparently did not come into existence until after Pamlico time.

The Black River is the principal Coastal Plain stream between the Pee Dee and the Santee. Its headwater streams rise in Kershaw, Lee, and Sumter Counties. Its principal tributaries are Scape Oer Swamp, Pocotaligo River, Pudding Swamp, and Black Mingo Creek. The river flows southeastward into Georgetown County, where it is diverted toward the northeast by a sandy ridge, apparently a spit or island built in the Talbot Sea, but it resumes its southeastward course at the mouth of Black Mingo Creek. It enters the Pee Dee a few miles above Georgetown.

The Edisto River is the principal stream between the Santee and the Savannah. It should be classified as a Coastal Plain stream, although its headwaters in Edgefield, Saluda, and Lexington Counties cut through the cover of Coastal Plain sediments into the underlying crystalline rocks. Its North Fork and South Fork flow parallel in a southeasterly direction as far as Orangeburg, where the North Fork turns south; the two forks join near Branchville. The main river continues southeastward to the mouth of Four Hole Swamp, its 
largest tributary, and thence runs southward through the sea islands. Two main distributaries, the North Edisto and South Edisto Rivers, enclose Edisto Island at its mouth.

From its source on the Aiken Plateau in northern Barnwel County, the Salkehatchie River flows southeast to its confluence with the Little Salkehatchie, its largest tributary, east of Cummings, to form the Combahee River, which continues in the same direction to St. Helena Sound. The straight course of the Salkehatchie and Combahee Rivers follows the original slope of the coastal terraces.

The Coosawhatchie River, which rises near Allendale, is also nearly straight. Its drowned lower part forms the Broad River and Port Royal Sound.

The Ashley and Cooper Rivers are short, young streams that unite at Charleston. The headwater stream of the Ashley River, Cypress Swamp, trends southwest through what was a shallow bay or tidal flat during Penholoway time, then turns seaward. The headwaters of the Cooper are formed by Biggin Swamp, Wadboo Swamp, and the East Branch.

The lower courses of all the streams flowing into the Atlantic Ocean in South Carolina have been drowned by a rise of sea level.

\section{DEVELOPMENT OF THE DRAINAGE}

The drainage pattern of all parts of South Carolina except the coastal terraces was well established before the beginning of the Pleistocene epoch and probably has undergone little change since that time.

During the Pliocene epoch the seashore lay somewhere within the area now occupied by the coastal terraces. That the sea must have covered at least part of this area is shown by the marine shell beds (the Waccamaw formation) of Pliocene age, which extend inland a considerable distance from the coast; that it did not cover all of the terraced area is indicated by the shape of the earliest Pleistocene shore line (Brandywine), which because of its crookedness and ruggedness appears to be a shore line of submergence. It seems probable that in South Carolina during Pliocene time the sea may have stood about 100 feet higher upon the land than it does today and that its shore may have extended from the vicinity of the Dillon-Horry County line about to the Hampton-Jasper County line.

The widespread earth movements that took place at the end of Pliocene time depressed the land perhaps about 170 feet and left the sea standing at the Brandywine shore line, about 270 feet above the present sea level. The wide valleys of the through-flowing rivers were converted into bays heading at the Fall Line, and tidewater probably extended up the gorges a considerable distance into the Piedmont. The lower parts of the valleys of the streams that headed in the much-narrowed Coastal Plain also were converted into estuaries. 
When the sea retreated to its low-level position during the first glacial stage, the larger rivers appear to have reoccupied their partly silted-up valleys and flowed out beyond the old Pliocene shore line across the newly exposed sea bottom. These lower courses followed the natural slope of the the land and were nearly straight. This process was repeated during each subsequent lowering of sea level. During each interglacial stage the sea flooded the land, and bars, spits, and islands were built up along the shore. These obstructions diverted many of the smaller streams from their direct courses to the sea, and as the water sank to lower levels they became new strips of Coastal Plain.

\section{STRATIGRAPHY}

\section{FORMATIONS INCLUDED}

The Coastal Plain of South Carolina consists entirely of sedimentary deposits that rest upon a surface of ancient rocks, chiefly granites, schists, and other crystalline rocks that are similar to and are the continuation of the rocks that underlie the adjoining Piedmont province. These basement rocks crop out in many ravines and gullies along the inner edge of the Coastal Plain and have been penetrated by the drill in deep wells.

In South Carolina the sedimentary rocks of the Coastal Plain range in age from Upper Cretaceous to Recent, but there are many breaks in the series. Their accumulation did not begin as early in South Carolina as in the States west of the Mississippi, where the oldest deposits of the Coastal Plain are of Lower Cretaceous age. The formations described are listed below in reversed chronologic order, beginning with the youngest.

Pleistocene:

Pamlico formation.

Talbot formation.

Penholoway formation.

Wicomico formation.

Sunderland formation.

Coharie formation.

Brandywine formation.

Pliocene:

Waccamaw formation.

Unnamed terrace deposits (perhaps contemporaneous with the Waccamaw).

Miocene:

Duplin marl.

Raysor marl.

Hawthorn formation.

Oligocene:

Flint River formation.

Eocene:

Barnwell sand $\left\{\begin{array}{l}\text { Cooper marl. } \\ \text { Santee limestone. }\end{array}\right.$ 
Eocene-Continued.

McBean formation.

Black Mingo formation.

Upper Cretaceous:

Peedee formation.

Black Creek formation.

Tuscaloosa formation.

The original extent of the Pleistocene formations is shown on plate 1 ; the approximate distribution of the formations older than the Pleistocene is shown on plate 2.

\section{OPPER CRETACEOUS SERIES}

\section{GENERAL FEATURES}

The deposits in South Carolina that represent the Cretaceous system are now all classified as Upper Cretaceous. The basal beds of the series for a time were referred to the Lower Cretaceous because of their resemblance to Lower Cretaceous beds in the Middle Atlantic States, but the fossil flora in them is of more recent aspect and shows them to be Upper Cretaceous. So far as now known, there are no deposits of Lower Cretaceous age in the Atlantic Coastal Plain south of Virginia.

The Upper Cretaceous of South Carolina is divisible into three formations, the Tuscaloosa at the base, the Black Creek in the middle, and the Peedee at the top. Each of the three formations is distinguished from the others by its peculiar lithology and is separated from the deposits above and below it by erosional unconformities. The Tuscaloosa consists chiefly of light-colored cross-bedded sand and lenses of massive light-colored clay and kaolin. It rests upon the ancient crystalline rocks of the Piedmont region. The Black Creek formation, which lies unconformably upon the Tuscaloosa, is much darker than the Tuscaloosa. Its lower part is chiefly very dark gray to black leaf-bearing clay and sand; its upper part, the Snow Hill marl member, is more sandy and contains marine shells. An unconformity, indicated by the absence of the Exogyra cancellata zone (see table below), separates it from the overlying gray sandy marl and marlstone of the Peedee formation.

The Tuscaloosa is the northeastward extension of beds typically exposed in Alabama. The Black Creek and Peedee formations crop out only in eastern South Carolina and the adjacent part of North Carolina, being separated from formations of the same age in other regions by wide overlaps of younger deposits. The correlation of the Upper Cretaceous formations east of the Mississippi River is shown in the accompanying table, which is based on the work of L. W. Stephenson. 
Correlation of the Upper Cretaceous formations east of the Mississippi River

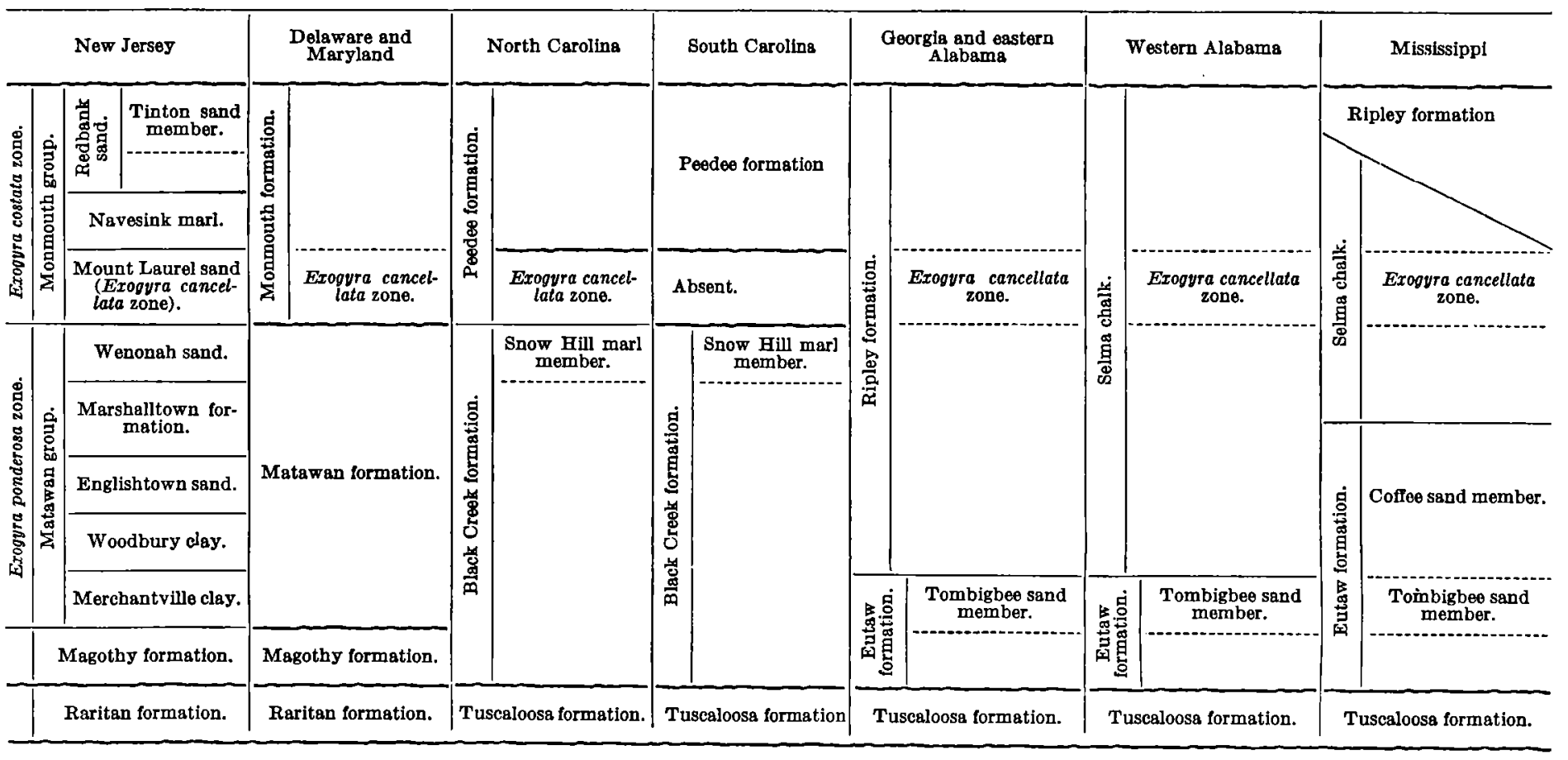




\section{TUSCALOOSA FORMATION}

GENERAL CHARACTER

The Tuscaloosa formation was named in 1887 by Smith and Johnson $^{13}$ from the city and river in Alabama. The local names ${ }^{\prime \prime H a m}-$ burg" "and f"Middendorf", from villages in Aiken and Chesterfield Counties, were applied by Sloan ${ }^{15}$ to certain clays and sand in South Carolina that were supposed to be of Lower Cretaceous age. E. W. Berry, ${ }^{16}$ on the evidence of the fossil plants, transferred the $†$ Middendorf beds to the Upper Cretaceous under the name t"Middendorf arkose member of the Black Creek formation." In 1926 I proposed to restore the $\nmid$ Middendorf to the rank of formation and to include in it the †Hamburg beds. ${ }^{17}$ At that time I correlated the †Middendorf formation with the Tuscaloosa formation of Alabama but deemed a local designation necessary, because the beds having a †Middendorf aspect in the intervening State of Georgia might represent a period of time somewhat longer than that of the Tuscaloosa and might include part or all of Eutaw time. Field work done in Georgia in 1930 shows that the $\nmid$ Middendorf there is quite different from the Eutaw formation but apparently identical with the Tuscaloosa. A local name for the beds in Georgia and South Carolina is therefore unnecessary, and the older name "Tuscaloosa formation" is here substituted for the name "Middendorf formation."

The Tuscaloosa formation is thought to include all the strata of Upper Cretaceous age exposed at the surface in South Carolina beneath the Black Creek formation, but it is possible that beds older than the Tuscaloosa formation may some day be differentiated from these deposits in North Carolina and South Carolina. The formation is probably 250 or 300 feet thick. It is characteristically exposed in a cut on the Seaboard Air Line Railway at the crossing of the Hartsville-Ruby road, 2 miles northeast of Middendorf, Chesterfield County. This cut was the type locality of the †Middendorf formation. The Tuscaloosa consists chiefly of light-gray, white, or buff sand, generally cross-bedded, and interfingering lenses of white, pink, or purplish clay. The formation is broken by many unconformities, all of them apparently local and none probably representing a great time interval.

\footnotetext{
12 Smith, E. A., and Johnson, L. C., Tertlary and Cretaceous strata of the Tuscaloosa, Tombigbee, and Alabama Rivers: U. S. Geol. Survey Bull. 43, pp. 98-116, 1887.

14 A dagger $(\dagger)$ preceding a geologic name indicates that the name has been abandoned or rejected for use in classification in publications of the U. S. Geological Survey. Quotation marks, formerly used to indicate abandoned or rejected names, are now used only in the ordinary sense.

is Sloan, Earle, A preliminary report on the clays of South Carolina: South Carolina Geol. Survey, ser. 4, Bull. 1, 1904. Handbook of South Carolina, South Carolina State Dept. Agr., Commerce, and Immigration, Columbia, 1907. Catalogue of the mineral localities of South Carolina: South Carolina Geol. Survey, ser. 4, Bull. 2, 1908.

16 Berry, E. W., The Upper Cretaceous and Eocene floras of South Carolina and Georgia: U. S. Geol. Survey Prof. Paper 84, pp. 68-72, 1914.

17 Cooke, Wythe, Correlation of the basal Cretaceous beds of the Southeastern States: U. S. Geol. Survey Prof. Paper 140, pp. 137-139, 1926.
} 
No animal remains have been found in the Tuscaloosa formation in South Carolina. Plants are not common but are abundant at a few places. Berry ${ }^{18}$ lists 41 species from the cut 2 miles northeast of Middendorf; 26 species from Rocky Point, near Sumter Junction; 6 species from Congaree River, 25 miles below Columbia; 17 species from a locality near Langley, Aiken County; and 7 species from Miles' Mill, Aiken County-in all, a compact flora of 63 species. Among the genera recognized are 5 species of fig, 2 of eucalyptus, 1 walnut, 3 willows, 1 oak, 1 laurel, 3 magnolias, 1 pine, and 1 sequoia. At the Middendorf cut Sequoia reichenbachii is the most abundant species.

The following list enumerates the fossil plants reported by Berry from the †Middendorf formation of South Carolina. The initial $\mathrm{R}, \mathrm{M}$, or $\mathrm{T}$ preceding a name in the list indicates that the species so marked occurs also in the Raritan or the Magothy formation of New Jersey or Maryland or in the Tuscaloosa formation of Alabama.

Acaciaphyllites grevilloides Berry

Andromeda euphorbiophylloides Berry

RMT Andromeda novaecaesareae Hollick

RMT Andromeda grandifolia Berry

T Andromeda parlatorii Heer Arundo groenlandica Heer

RT Brachyphyllum macrocarpum Newberry Caesalpinia middendorfensis Berry Calycites middendorfensis Berry

M Carex clarkii Berry

RT Celastrophyllum crenatum Heer

M Celastrophyllum elegans Berry

RT Celastrophyllum carolinensis Berry Cinnamomum middendorfensis Berry

RMT Cinnamomum newberryi Berry

MT Citrophyllum aligerum (Lesquereux) Berry

T Crotonophyllum panduraeformis Berry

RM Cunninghamites elegans (Corda) Endlicher

T Dewalquea smithi Berry

RMT Diospyros primaeva Heer

MT Diospyros rotundifolia Lesquereux

RMT Eucalyptus geinitzi Heer

Proteoides lancifolius Heer

Proteoides parvula Berry

M Protophyllocladus lobatus Berry

Quercus pseudowestfalica Berry

Quercus sumterensis Berry

Sabalites carolinensis Berry

RMT Salix flexuosa Newberry

RMT Salix lesquereuxii Berry

R Salix pseudohayei Berry

Salix sloani Berry

RMT Sequoia reichenbachi (Geinitz) Heer

RMT Sapindus morrisoni Heer

RMT Widdringtonites subtilis Heer

ls Berry, E. W., op. cit., p. 72. 


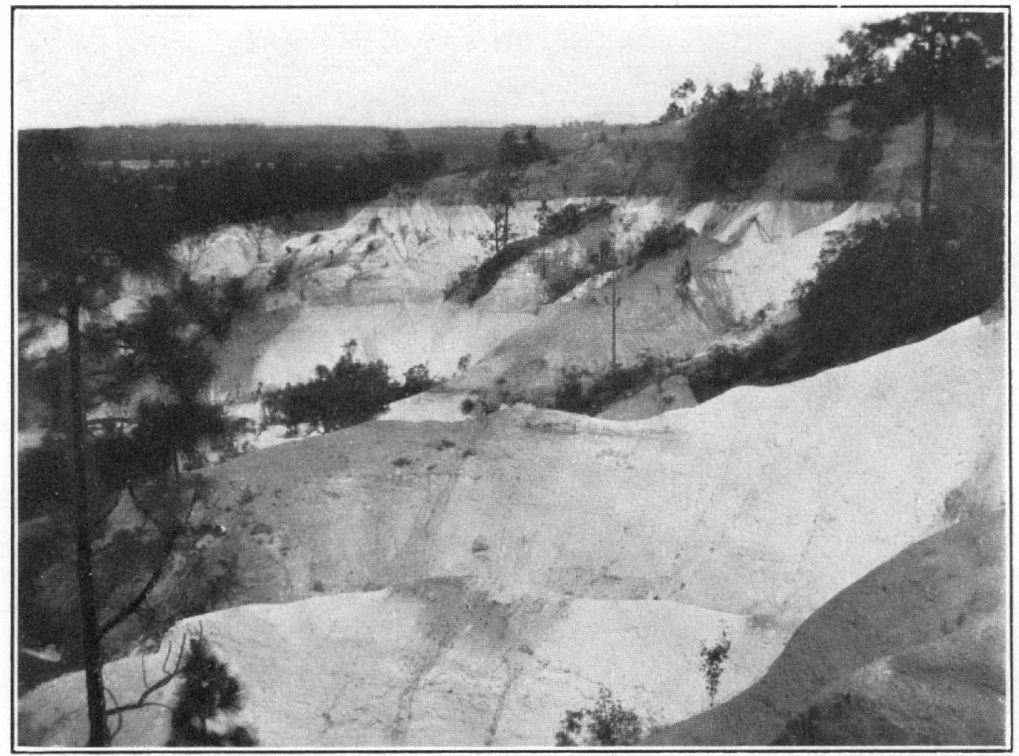

A. EROSION IN THE AIKEN PLATEAU EXPOSING THE UPPER CRETACEOUS TUSCALOOSA FORMATION ON UPPER AIKEN-GRANITEVILLE ROAD 4 MILES WEST OF AIKEN.

Photograph by L. W. Stephenson.

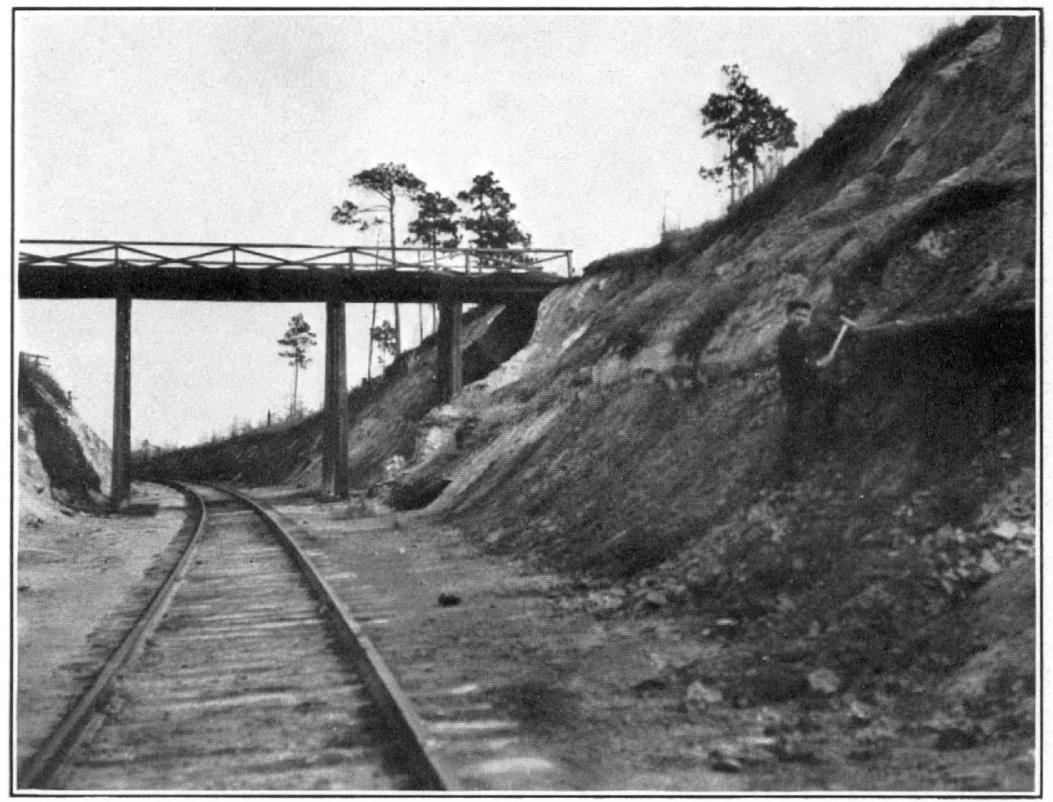

B. TUSCALOOSA FORMATION 2 MILES NORTHEAST OF MIDDENDORF. Photograph by L. W. Stephenson. 


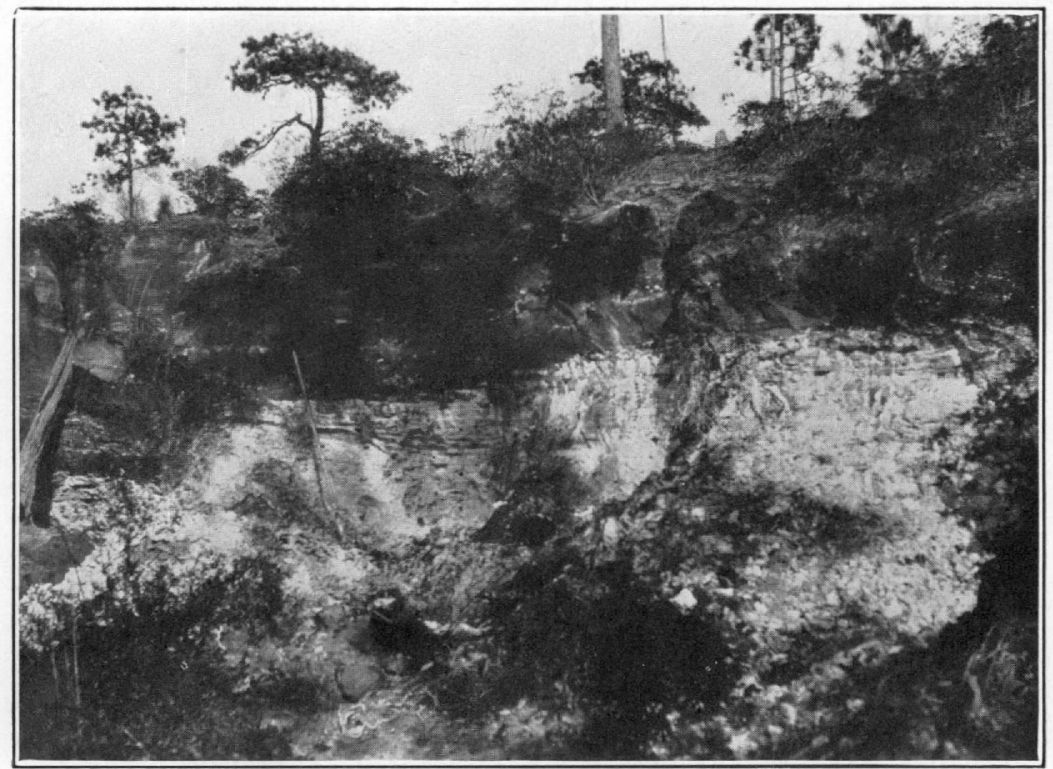

A. TUSCALOOSA FORMATION 1 MILE NORTH OF LANGLEY.

Photograph by L. W. Stephenson.

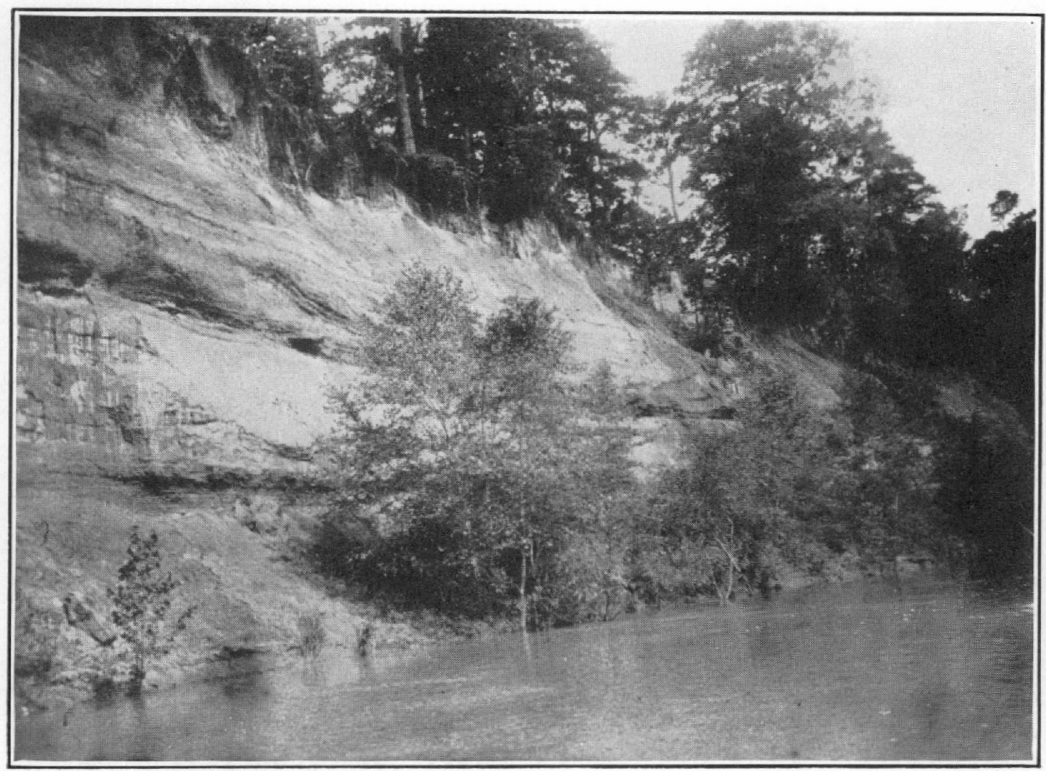

B. MARS BLUFF, PEE DEE RIVER.

Photograph by L. W. Stephenson. 
In South Carolina the Tuscaloosa formation rests directly upon the crystalline rocks of the Piedmont without the interposition of older Cretaceous deposits. The time interval represented by this unconformity is enormous-probably many millions of years. It includes all of Triassic, Jurassic, and Lower Cretaceous time, probably much of Paleozoic time, and perhaps the early part of the Upper Cretaceous. The unconformity that separates the Tuscaloosa from the overlying Black Creek represents a much shorter interval, but the exact duration of the break is unknown.

Sand and gravel like those of the Tuscaloosa formation and doubtless of the same age make up at least the greater part of the fCape Fear formation of North Carolina, which is now designated "Tuscaloosa", although it is possible that beds older than the typical Tuscaloosa may be included in it.

According to Berry the flora of the Tuscaloosa formation shows close kinship to those of the Raritan and Magothy formations, which make up the basal part of the Upper Cretaceous in the Middle Atlantic States. Stephenson ${ }^{19}$ considers the Tuscaloosa formation to be contemporaneous with the Raritan.

The Tuscaloosa formation extends from the North Carolina boundary through northern Marlboro, Chesterfield, northern Darlington, northern Lee, Kershaw, western Sumter, Richland, northern Calhoun, eastern Lexington, and northern Aiken Counties. Throughout most of this area it gives rise to sand hills, many of which have been shaped by the wind into dunes. Such sand hills are particularly conspicuous in Lexington County south of Columbia.

\section{DILLON COJNTY}

The easternmost outcrops in South Carolina that have been referred to the Tuscaloosa formation occur in the west bluff of the Little Pee Dee River, $1 \frac{132}{2}$ miles east-southeast of Dillon. The section there is as follows:

Section at edge of swamp of Litlle Pee Dee River, $1 \frac{112}{2}$ miles east-southeast of Dillon (1) ${ }^{\text {so }}$

2. Sunderland formation (Pleistocene): Coarse orange, red, and yellow cross-bedded sand and gravel; to level of plain on which Dillon is built........................ 15

Unconformity.

1. Tuscaloosa formation (Upper Cretaceous): White and pink sandy clay changing laterally into coarse white crossbedded arkosic sand; to river swamp, about

10 Stephenson, L. W., Correlation of the Upper Cretaceous or Gulf series of the Gulf Coastal Plain: Am. Jour. Sci., 5th ser., vol. 16, flg. 1, 1928.

${ }^{20}$ Numbers in parentheses refer to corresponding numbers on plate 1. 


\section{MARLBORO COUNTY}

The Tuscaloosa formation is exposed in the northern part of Marlboro County. South of Naked Creek and in the neighborhood of the Pee Dee River it is covered by Pleistocene terrace deposits. High-level gravel near the North Carolina line is probably Pliocene. The Tuscaloosa deposits in Marlboro County consist chiefly of coarse, tough argillaceous sand, commonly gray, buff, or drab but weathering yellowish or reddish.

\section{CHESTERFIELD COUNTY}

The Tuscaloosa formation covers all of Chesterfield County except the northern part, which is underlain by ancient crystalline rocks, and the eastern border, which is covered by terrace deposits.

Eureka mill pond (2).-Several feet of gray compact sand resembling parts of the Tuscaloosa (†Cape Fear) formation of North Carolina causes a fall at the old Eureka mill pond, south of the Camden highway 5 miles southeast of Cheraw. The sand hills of this part of the county appear to be formed of sand derived from this kind of material.

Patrick (3).-On the hillside south of United States Highway 1, 2 miles west by south of Patrick, is a ledge about 2 feet thick of hard gray claystone containing poorly sorted sand grains. This rock closely resembles certain facies of the fCape Fear formation. It is somewhat harder than the bed at the Eureka mill pond, 10 miles farther east. The highway passes through pinkish arkosic sand containing lenses of white or gray clay.

Middendorf (4). - The railroad cuts at Middendorf show only buff sand. The type locality of the †Middendorf formation is the cut on the Seaboard Air Line Railway at the overhead crossing of the Ruby road, 2 miles northeast of Middendorf (pl. 11, $B$ ). The cut exposes cross-bedded gray to pink arkosic sand containing lenses of light-colored clay. A 4-foot clay lens containing many well-preserved leaf impressions extends from a point near the bridge westward about 100 feet, but eastward it grades into tough gray argillaceous sand. Berry ${ }^{21}$ describes the section at this place and lists 41 species of fossil plants from the clay lens.

Sugar Loaf Mountain (5).-According to unpublished notes of L. W. Stephenson, Sugar Loaf Mountain, 4 miles west-northwest of Patrick, is a nearly round hill 400 or 500 feet in diameter at the base and about 110 feet high. The top is capped by a small flat remnant of coarse ferruginous sandstone 3 feet thick and 15 feet long. The top is about 460 feet above sea level (aneroid reading). A gully on the north side shows that the hill is composed of medium-grained to very coarse arkosic micaceous cross-bedded sand (Tuscaloosa forma-

\footnotetext{
21 Berry, E. W., The Upper Cretaceous and Eocene floras of South Carolina and Georgia: U. S. Geol. Survey Prof. Paper 84, pp. 8-9, 1914.
} 
tion), parted by a few layers of clay. The sand is variegated with different hues of pink, yellow, purple, and red. It contains some balls of clay.

Big Spring (6).-On the east bank of the Lynches River above Big Spring is a 20 -foot bluff of hard gray sandy clay somewhat mottled with purple and pink. The spring from which the settlement takes its name is on the west side of the river, in Kershaw County. It issues from the Tuscaloosa formation under considerable hydrostatic pressure and is said to flow 350 gallons a minute. The temperature is reported to be $57^{\circ} \mathrm{F}$.

$M c B e e$.-From the town of $\mathrm{McBee}$, near the southern edge of the sand hills, loose buff sand with scattered exposures of gray clay extends northwestward to Little Sandy Creek and northward probably almost to Ruby. This sand is derived from the Tuscaloosa formation.

\section{DARLINGTON COUNTY}

The Tuscaloosa formation crops out along the northern boundary of Darlington County in an irregular belt of sand hills. Along the Pee Dee River it extends as far south as the Cashua Ferry road, eastnortheast of Darlington, where it passes below the Black Creek formation. The point where it sinks below water level on the Lynches River has not been discovered.

Floyd's mill (7).-At Floyd's old mill (later Isgat's), 7 miles northeast of Darlington and 2 miles N. $55^{\circ} \mathrm{W}$. of Mechanicsville, the contact of the Tuscaloosa and the Black Creek is exposed. The section is as follows:

\section{Section at Floyd's mill}

2. Black Creek formation: Laminated dark-brown clay and sand; at base a thin conglomeratic stratum containing grains of quartz and rounded lumps of dark clay derived from the lower bed. . . . . Unconformity.

1. Tuscaloosa formation: Compact dark-brown clay with hackly or conchoidal fracture; to creek bed, about.....

Cashua Ferry road (8).-A small exposure of light-gray sandy clay resembling the Tuscaloosa formation was found beneath the Black Creek formation at the foot of the bluff above Pee Dee Swamp, 1.3 miles northeast of Mechanicsville (Riverdale) on the Cashua Ferry road. The contact of the two formations was not seen at this place, but the concealed interval between them was only a few inches. The Black Creek formation consists of more than 30 feet of dark-gray clay containing thin partings of fine micaceous sand and comminuted plant remains.

Hartsville (9).-The Tuscaloosa formation, consisting chiefly of light-gray plastic clay, is exposed in a gully heading opposite No. 
1700 Home Avenue in the western outskirts of Hartsville. It is overlain by pebbly sand of the Pleistocene Coharie formation.

Society Hill (10).-On the slope south of Society Hill tough light blue-gray Tuscaloosa clay containing angular grains of sand is overlain unconformably by pebbly red sand of Pleistocene age.

\section{LEE COUNTY}

The northwest third of Lee County is covered by the Tuscaloosa formation. In this county the formation exhibits no noteworthy peculiarities but as in the adjoining counties consists chiefly of lightcolored micaceous arkosic sand that gives rise to sand hills.

\section{SOMTER COUNTY}

The Tuscaloosa formation crosses the northwest corner of Sumter County and extends down the valley of the Wateree River. From Wedgefield southward it is overlain by patches of the Black Creek formation, but north of Wedgefield the Eocene Black Mingo formation overlaps upon it.

Rocky Point (11).-At Rocky Point, a bluff rising 75 feet or more above the railroad tracks half a mile northeast of Sumter Junction, light-gray clay and coarse gray sand at the base of the section are tentatively referred to the Tuscaloosa formation. The overlying darker clay, sand, and ledges of ferruginous sandstone, which contain an abundant flora that was regarded by Berry as of $\nmid$ Middendorf age, possibly belong to the Black Creek formation.

Wedgefield (12).- In a cut on the Atlantic Coast Line Railroad 1 mile west of Wedgefield (pl, 13, A), about 30 feet of variegated clay and coarse arkosic sand underlies unconformably about 23 feet of thinbedded yellow sand, ferruginous sandstone, and laminated brittle clay. The lower bed resembles the Tuscaloosa formation in color, texture, and composition; the upper bed is probably of Black Creek age.

\section{KERSHAW COUNTY}

The greater part of Kershaw County is underlain by the Tuscaloosa formation, but the northwest corner is in the Piedmont. Terrace deposits conceal the Tuscaloosa along the Wateree River.

The base of the Tuscaloosa, consisting of buff sand on greasy sericite schist, is exposed on the descent to Twenty-five Mile Creek on the Winnsboro road, 3.3 miles northwest of Blaney. The altitude of the contact is 110 feet lower than Blaney (aneroid reading).

At some places in Kershaw County, especially south and southeast of Kershaw, the lower part of the Tuscaloosa contains more gravel and is more highly ferruginous than is common for the formation in South Carolina. This greater iron content, indicated by a redder color, is probably due to the source from which the sediments were derived, those from granitic rocks being more ferruginous than those from the schists. 
The sand hills of Richland County are derived from the Tuscaloosa formation. They occupy a large area mostly north of the latitude of Columbia and east of Crane Creek.

Killian (13).- The most extensive exposure of the Tuscaloosa noted is in the abandoned clay pits $2 \frac{11}{2}$ miles northeast of Killian. The workings are about 60 feet deep, 200 or 300 feet long, and cut in the side of a hill from whose summit the city of Columbia is visible. There are two principal beds separated by a sharp, gently undulating line. The lower bed, about 35 feet thick, consists chiefly of white kaolin containing lenses of coarse sand. The upper bed, about 25 feet thick, is loose white to buff sand, coarsest at the bottom. In places the sand immediately above the kaolin is cemented by limonite. The sharp contact between the two beds has probably little time significance.

Columbia-Camden highway (14).-There are many exposures of the sands and clays of the Tuscaloosa formation along the road from Camden to Columbia. In a cut of the Seaboard Air Line Railway beneath the highway bridge 10.4 miles northeast of Columbia a lens of light-gray to white and pinkish clay 2 to 10 feet thick is overlain by 6 to 15 feet of buff sand containing lenses of sandy white clay.

Horrell Hill (15).- The pits of the Interstate Clay Co., on the west side of Cedar Creek about half a mile southeast of Horrell Hill, expose white and pink kaolin overlain by a variable thickness of pink to reddish sand.

Columbia.-In the vicinity of Columbia the basal beds of the Tuscaloosa formation are exposed at many places. For the most part they consist of sand of varying degrees of coarseness, generally cross-bedded, and at some places containing cobbles several inches in diameter. Lenses of more or less sandy clay are common. The prevailing color is light gray or buff, but pinks and purples are not uncommon.

\section{CALHOUN COUNTY}

Congaree River.-Berry ${ }^{22}$ lists six species of plants from a locality on the bank of the Congaree River about 25 miles below Columbia. They were found in pale-buff micaceous, finely arenaceous thinlaminated clay.

Fort Motte (16).-Underlying the †Lang Syne beds of Sloan, here regarded as a part of the Black Mingo, on the Lang Syne plantation, 11/2 miles east of Fort Motte, are several exposures of light Tuscaloosa clay. A fuller description of the geology in this vicinity is recorded on page 69.

High Hill Creek (17).-The Tuscaloosa formation exposed near Calvary Church, 4.5 miles north of St. Matthews, consists of 30 feet of coarse gray, somewhat micaceous sand in a matrix of white clay.

22 Berry, E. W., op. cit., p. 10. 
It is overlain unconformably by dark-blue to black carbonaceous clay probably of Black Mingo age. (See section, p. 54.)

Halfway Swamp (18).-According to Vaughan, ${ }^{23} 6$ or 7 feet of pale-greenish clay with waxy luster, in places streaked with red and purple, is exposed on the east side of Halfway Swamp below the Atlantic Coast Line Railroad bridge half a mile northeast of Creston. It is overlain unconformably by 4 feet or less of reddish clay with pea-green partings. This exposure is farther downstream than any other known outcrop of the Tuscaloosa in the Santee drainage basin.

IEXINGTON COUNTY

The southern two-thirds of Lexington County is underlain by the Tuscaloosa formation, but south of Edmund the Tuscaloosa is covered by the Eocene McBean and Barnwell formations. The Tuscaloosa is composed chiefly of buff sand and variegated clay. Much of the sand is unconsolidated and has been drifted by the wind.

\section{AIREN COUNTT}

Although the Tuscaloosa formation underlies nearly all of Aiken County, it is overlapped by Eocene sand that extends beyond the limits of the Tuscaloosa and rests on the crystalline rocks of the Piedmont. The Tuscaloosa is exposed in the valleys of the North and South Forks of the Edisto River, Shaw Creek, Horse Creek, and the Savannah River.

Seivern.-Pink and white Tuscaloosa clay is exposed in an old kaolin pit north of the village of Seivern. It is overlain unconformably by red pebbly sand.

Aiken.-Tuscaloosa clay is exposed beneath Eocene beds supposed to be of Barnwell age at Calico and Coker Springs, at Aiken, and also at Dibble's fishpond, 6 miles southeast of Aiken. About 20 feet of white sandy clay is exposed in a cut on the Southern Railway at the crossing of the Augusta road, 2 miles west of Aiken. It is overlain unconformably by variegated sand, weathered bright red at the top, and lenses of clay.

Langley.-According to Berry, ${ }^{24}$ a shallow gully east of the old Augusta road 1 mile north of Langley and half a mile west of Langley Dam, on Bighorse Creek (pl. 12, $A$ ), has cut into clay of the †Middendorf formation to a depth of about 8 feet. The material is white massive kaolin containing impressions of leaves. Berry lists from this place 17 species of fossil plants, 8 of which occur also at Middendorf.

Hamburg (19).-The following section is exposed on United States Highway 1, at Hamburg, between the Southern Railway crossing and the top of the hill:

\footnotetext{
23 Vaughan, T. W., unpublished_notes, November 24, 1907. 2 Berry, E. W., op. cit., p. 10.
} 


\section{Section at Hamburg}

2. Pleistocene: Coarse argillaceous arkosic cross-bedded sand containing pebbles and small pellets of clay. Somewhat more compact and redder than bed 1 and partly mottled with rusty patches; to terrace plain at top of hill (more than 200 feet above sea level); thickness about......... Unconformity.

1. Tuscaloosa formation (Upper Cretaceous): Fine and coarse white micaceous sand weathering various shades of red and purple and containing lenses of white, pink, and brownish clay. Clay most abundant at top. Extends from railroad crossing ( 145 feet above sea level) to bend in road; top irregular; thickness about.............

The basal beds of the Tuscaloosa formation are exposed in gravel pits in the bluffs between Hamburg and North Augusta, less than half a mile northwest of United States Highway 1. They consist of 15 to 20 feet of coarse white clayey sand containing large angular boulders of quartz at the contact with the underlying deeply weathered schist. The Tuscaloosa is overlain unconformably by coarse yellow to deep-red sand containing gravel and pebbles at the base. This upper sand bed varies in thickness but is probably as much as 75 feet thick at some places. Its upper surface is a welldefined ancient terrace between 220 and 240 feet above sea level.

\section{BLACK CREFK FORMATION}

\section{GENERAL CHARACTBR}

The name "Black Creek shale" was applied by Sloan ${ }^{25}$ in 1907 to beds exposed along Black Creek in Florence and Darlington Counties and along the Pee Dee River from a point near Society Hill to the mouth of Jeffries Creek. In 1908 Sloan ${ }^{26}$ described it as comprising "unctuous black shaly clays enclosing interlaminations of extremely thin micaceous seams and occasional fine-grained sand." Although no locality was specified by Sloan as the type, the outcrops of the formation on Black Creek near the crossing of the Cashua Ferry road east of Darlington may be regarded as typical.

The Black Creek formation consists principally of very dark gray laminated clay and micaceous sand. Clay predominates at the typical exposures, which represent the lower part of the formation, but sand is more abundant in the Snow Hill marl member, at the top. The formation is exposed along Black Creek and its tributaries from a point a few miles above Darlington to the swamp of the Pee Dee River; along the west bluff of the Pee Dee from Floyd's mill (7), in

a SIoan, Earle, Handbook of South Carolina, p. 88, South Carolina Dept. Agr., Commerce, and ImmiBration, 1907.

${ }^{26}$ Sloan, Earle, Catalogue of the mineral localities of South Carolina: South Carolina Ceol. Survey, ser. 4, Bull. 2, p. 442, 1908. 
Darlington County, to Burches Ferry (27), and possibly lower in Florence County; along Jeffries Creek from the vicinity of the Darlington-Florence county line to its mouth; and along the Little Pee Dee River from Nicols nearly to Galivants Ferry. Beds east of the Wateree River below Wedgefield and on Wyboo Creek (84) in Clarendon County may represent the Black Creek formation. As the deposits dip gently toward the southeast, beds successively higher in the stratigraphic section are exposed downstream.

As the Black Creek formation is covered nearly everywhere by younger deposits, its effect upon the topography of the region is negligible. Its most striking outcrop is in Mars Bluff (26), a high cliff on the Pee Dee River, but the position and height of this bluff were only in small degree determined by the physical characteristics of the Black Creek formation.

In the typical part of the Black Creek formation-that is, near Darlington-plants are the only organisms that have been found. The following 15 species of plants are listed by Berry ${ }^{27}$ from 4 localities:

Algites americana Berry

Cephalotaxospermum carolinianum

Berry

Araucaria bladenensis Berry

Araucaria darlingtonensis Berry

Strobilites anceps Berry

Myrica brittoniana Berry

Myrica elegans Berry

\begin{tabular}{|l} 
Salix lesquereuxii Berry? \\
Ficus krausiana Heer \\
Proteoides lancifolius Heer \\
Magnolia newberryi Berry? \\
Rhus darlingtonensis Berry \\
Laurophyllum nervillosum Hollick? \\
Eucalyptus angusta Velenovsky \\
Hedera primordialis Saporta?
\end{tabular}

Salix lesquereuxii Berry?

Ficus krausiana Heer

Proteoides lancifolius Heer

Magnolia newberryi Berry?

Rhus darlingtonensis Berry

Laurophyllum nervillosum Hollick?

Hedera primordialis Saporta?

Of these species, Araucaria bladenensis appears to be especially characteristic of the Black Creek formation. It has been found at several places in the Black Creek formation of North Carolina and is recorded from the Cusseta sand member of the Ripley formation of Georgia and from the basal bed of the Eutaw formation in Hale County, Ala.

The upper part of the Black Creek formation carries a large and characteristic marine molluscan fauna. To this member of the formation Stephenson ${ }^{28}$ has applied the name "Snow Hill", from a locality in North Carolina. Collections of fossils from the Snow Hill member have been obtained in South Carolina from Hodges old mill (28) and Mars Bluff (26).

The Black Creek formation rests unconformably upon the Tuscaloosa formation. The contact has been seen at a few places, notably at Floyd's old mill (7). Elsewhere the abrupt change in lithology and the presence of a basal conglomerate in the Black Creek give additional evidence of a break in deposition. In South Carolina the

\footnotetext{
${ }^{7}$ Berry, E. W., The Upper Cretaceous and Eocene floras of South Carolina and Georgla: U. 8. Geol . Survey Prof. Paper 84, p. 72, 1914.

28 Stephenson, L. W., Cretaceous formations of North Carolina, pt. 1, Invertebrate fossils of the Upper Cretaceous formations: North Carolina Geol. and Econ. Survey, vol. 5, pt. 1, p. 9, 1923.
} 


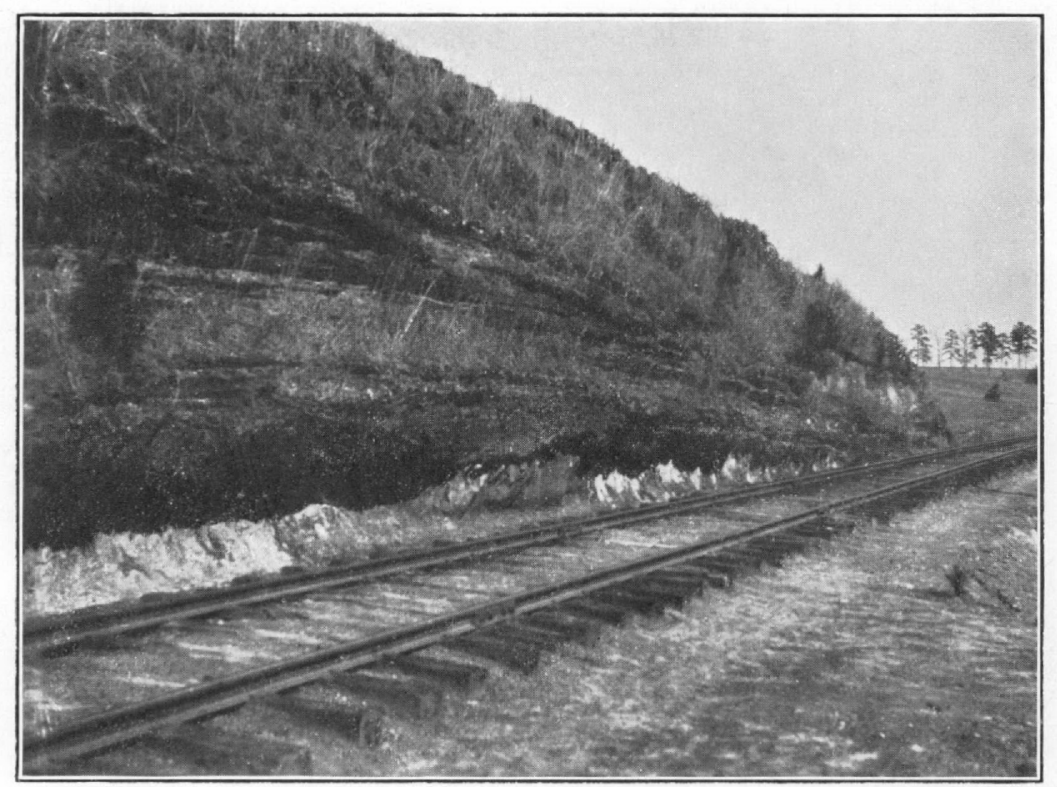

A. TUSCALOOSA-BLACK CREEK (?) CONTACT 1 MILE WEST OF WEDGEFIELD. Photograph by L. W. Stephenson.

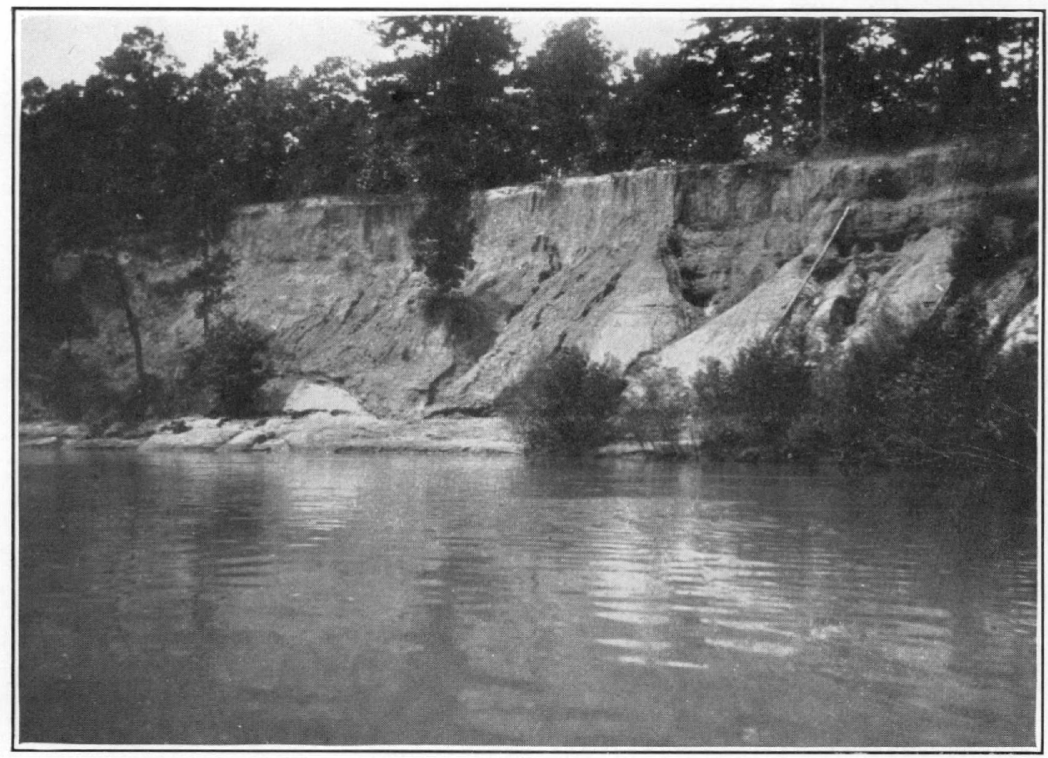

B. DEWITTS BLUFF, PEE DEE RIVER,

Photograph by L. W. Stephenson. 


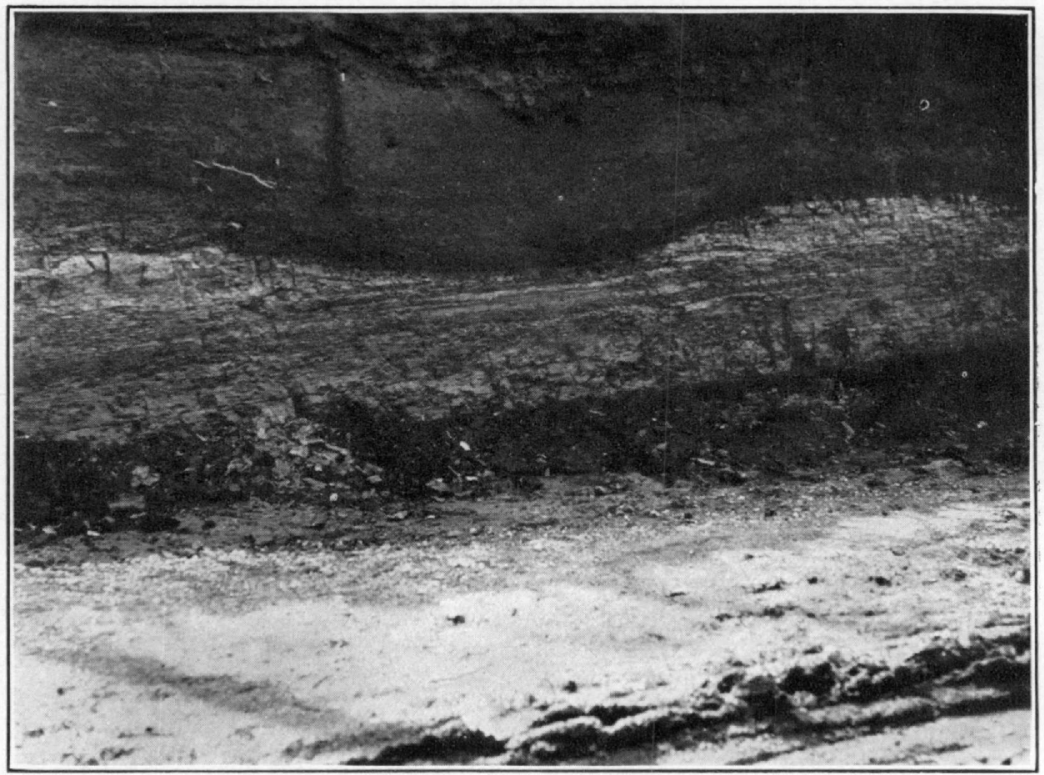

A. CONTACT BETWEEN THE BLACK MINGO FORMATION AND THE MCBEAN FORMATION NEAR BATES MILL, CALHOUN COUNTY.

Photograph by L. W. Stephenson.

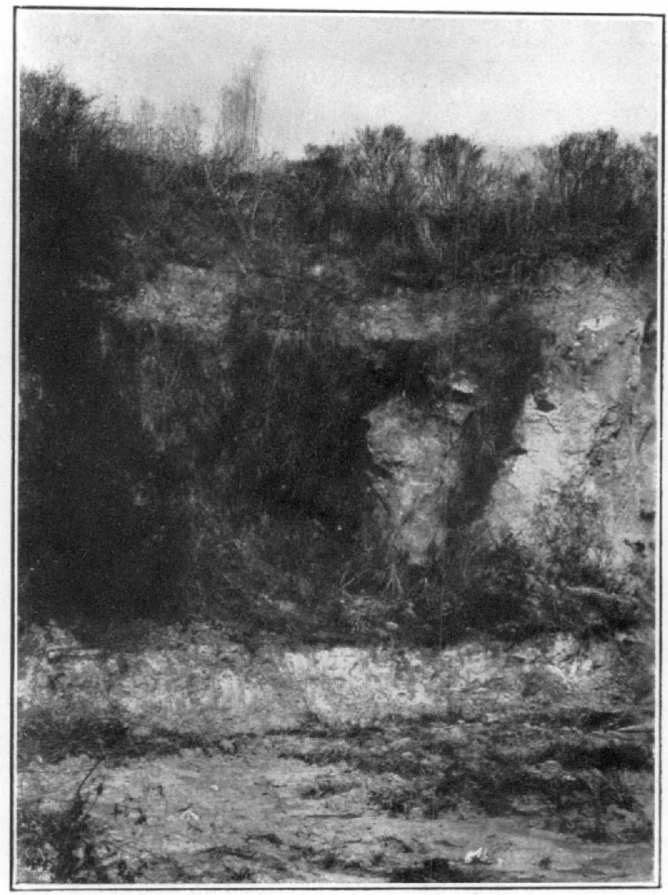

B. MARL PIT AT LAMBS.

Photograph by G. R. Mansfield. 
Black Creek is unconformably overlain by the Peedee formation or by younger deposits. This unconformable contact is exposed at Burches Ferry (27). The lithologic evidence of a break is afforded by a slight irregularity in the contact and by the presence of a fow rounded pebbles of chert in the base of the Peedee formation. Confirmation of this evidence is found in the fossils, for at Burches Ferry the Black Creek formation is directly overlain by the upper part of the Peedee formation, and the Exogyra cancellata zone, which normally forms the lower part of the Peedee, is missing. (See table on p. 16.)

There are no very reliable estimates of the thickness of the Black Creek formation in South Carolina. A well at Charleston ${ }^{20}$ that was drilled to a depth of 2,000 feet is supposed to have entered the Black Creek formation at a depth of about 1,550 feet and to have remained in it to the bottom. The mollusk Exogyra upatoiensis, which characterizes the basal zone of the Eutaw formation in Georgia, was found near the bottom of the well.

\section{DARLINGTON COONTY}

Floyd's mill (7).-At the site of Floyd's old mill (later Isgat's), 7 miles northeast of Darlington and 2 miles N. $55^{\circ} \mathrm{W}$. of Mechanicsville, the lower part of the Black Creek formation is exposed, overlying unconformably the Tuscaloosa formation. The section is given on page 21.

Mechanicsville (20).-Where the Cashua Ferry Road leads down to the swamp of the Pee Dee River, 1 mile northeast of Mechanicsville and 8 miles northeast of Darlington, both the Tuscaloosa and the Black Creek formations are exposed, but the contact was covered when the section given below was described.

\section{Section on Cashua Ferry Road near Mechanicsville}

3. Sunderland formation (Pleistocene): Coarse pebbly compact sand at base, passing upward into finer sand laminated with clay; reddish yellow to red and gray; to top of hill, about

Unconformity.

2. Black Creek formation (Upper Cretaceous): Dark-brown to

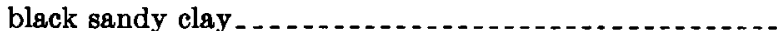

Probable unconformity; contact covered.

1. Tuscaloosa formation (Upper Cretaceous): Coarse lightgray argillaceous sand.

Feet

About three-fourths of a mile north of the road 40 feet of crossbedded yellow sand interbedded with grayish-brown micaceous clay is exposed in the bluff. At the bottom is a 2-foot conglomeratic bed

\footnotetext{
"Stephenson, L. W., A deep well at Charleston, S. C.: U. S. Geol. Surver Prof. Paper 90, pp. 69-90, 1914. 
composed of coarse pebbly sand and gray and black clay balls. The underlying formation is not exposed.

Red Landing, Louthers Lake (21).-The old oxbow of the Pee Deo River 8 miles east of Darlington, known as "Louthers Lake", strikes the upland at a bluff 60 feet high. The foot of this bluff is covered by broken brown clay, possibly fallen from above. Exposures in the upper 22 feet show interlaminated brown bedded clay and yellow sand. Somewhere in this bluff Berry ${ }^{30}$ found fragmentary leaves. The sands and clays at Red Landing resemble the Black Creek formation at Mars Bluff, but they are probably somewhat lower in the formation.

High Hill Creek (22).-At the county line on the road from Darlington to Florence about 5 feet of fine yellow laminated sand and dark-gray brittle clay of the Black Creek formation is unconformably overlain by 8 to 10 feet of coarse reddish sand and gravel of Pleistocene age.

Black Creek (23).-Where the Cashua Ferry Road descends to Black Creek, 1 $1 \frac{1}{2}$ miles northeast of Darlington, 7 feet of fine brown laminated micaceous sand and clay of the Black Creek formation is exposed on the roadside. From the creek bank 750 feet below the bridge Stephenson collected from similar materials fossil leaves that Berry ${ }^{30}$ identified as Araucaria darlingtonensis, Ficus krausiana, and Strobilites anceps. Berry also reports Eucalyptus angusta, Ficus krausiana, and Myrica brittoniana from the base of a 25-foot exposure of dark carbonaceous clay interlaminated with yellowish, locally indurated lignitic sand on the right bank of Black Creek about 2 miles below Williamsons Bridge and probably not far above the Florence County line.

\section{FLORENCE COUNTI}

Ashby place (24).-On the descent to a small branch of Black Creek, 2 miles N. $10^{\circ} \mathrm{E}$. of the overhead railroad crossing east of Florence, 25 or 30 feet of fine gray laminated argillaceous sand is exposed on the public road near the Ashby residence. It is probably referable to the Black Creek formation.

Florence (25).- - On the roadside at the south edge of the swamp of Jeffries Creek, 1 mile south of Florence, about 8 feet of alternating thin beds of chocolate-colored semiplastic clay and fine red micaceous sand, apparently Black Creek formation, is exposed. No fossils were found.

Mars Bluff (26).--About 10 miles east of Florence the Pee Dee River swings against a 70-foot cliff known as "Mars Bluff" (pl. 12, B). As the highway from Florence to Marion crosses the river at Mars Bluff Ferry, the section exposed there early attracted the attention

2 Berry, E. W., op. cit., p. 11. 
of geologists. Ruffin ${ }^{31}$ and Tuomey ${ }^{32}$ referred all the strata to the Cretaceous, but Darton ${ }^{33}$ and Sloan ${ }^{34}$ referred the greater part of the section to the Eocene. The beds, however, resemble the Black Creek formation, and the fossils in them show that they are correlative with the Snow Hill marl member of the Black Creek. The section given below represents the lower end of the bluff. The thicknesses are adapted from the section published by Sloan.

\section{Section at Mars Bluff}

Wicomico formation (Pleistocene):

Feet

5. Yellow to bluish sandy clay with a $1 \frac{1}{2}$-foot pebble bed at base. . . . . . . . . .

Unconformity.

Black Creek formation (Upper Cretaceous):

4. Fine yellow stratified sand containing a few laminae of gray clay ............... 10

3. Dark-gray to black clay interbedded with sand ..... $3 \frac{1}{2}$

2. Fine buff, pink, and gray cross-bedded sand $\ldots \ldots \ldots 11$

1. Dark-gray to black clay interbedded with fine yellow sand containing several thin fossiliferous strata near the top. The shell bed is unevenly indurated into hard or friable sandstone. Silicified shells, chiefly bivalves, abundant. To low-water mark in the Pee Dee River. . . . . . . .

The fossils in the lowest bed at Mars Bluff were puzzling but were finally identified by Stephenson ${ }^{35}$ as follows:

Coelenterata:

Sponge borings in shell of Tellina

Coral, one species

Molluscoidea:

Bryozoa

Pelecypoda:

Leda sp.

Breviarca poguei (Stephenson)

Glycymeris? greenensis Stephenson (numerous)

Arca (Barbatia) bladenensis Stephenson

Arca (Barbatia) lintea (Conrad)

Ostrea sloani Stephenson

Anomia olmstedi Stephenson?

Veniella mullinensis Stephenson

Crassatellites sp.

Lucina sp.

Cardium donohuense Stephenson

" Ruffin, Edmund, Report of the commencement and progress of the agricultural survey of South Carolina for 1843, p. 27, Columbia, S. C., 1843.

as Tuomey, Michsel, Report on the geology of South Carolina, p. 136, Columbia, S. C., 1848.

" Darton, N. H., Notes on relations of lower members of the Coastal Plain series in South Carolina: Geol. Soc. America Bull., vol. 7, p. 516, 1896.

24 Sloan, Earle, Catalogue of the mineral localities of South Carolina: South Carolina Geol. Survey, ser. 4, Bull. 2, p. 358, 1908.

as Stephenson, L. W., Additions to the Upper Cretaceous invertebrate faunas of the Carolinas: U. $\mathbf{S}$. Nat. Mus. Proc., vol. 72, art. 10, pp. 3-5, 1927. 
Pelecypoda-Continued.

Cardium sp. aff. C. vaughani Stephenson

Cardium marsense Stephenson

Cyprimeria sp.

Tellina simplex Stephenson

Tellina elliptica Conrad?

Tellina sp.

Linearia carolinensis Conrad?

Cymbophora trigonalis Stephenson

Cymbophora sp. (large)

Corbula oxynema Conrad

Corbula subgibbosa Conrad?

Corbula sp.

Unidentified pelecypods (several species)

Scaphopoda:

Dentalium leve Stephenson

Gastropoda:

Nerita sp.

Epitonium sp.

Lunatia carolinensis Conrad

Lunatia sp.

Gyrodes? sp.

Turritella sp.

Pugnellus sp.

Odontobasis(?) greenensis Stephenson?

Unidentified gastropods (several species)

Vertebrata:

One fish vertebra

All the forms specifically identified occur in the Snow Hill marl member of the Black Creek formation, and the containing bed is therefore correlated with that member.

Burches Ferry (27).-The southernmost exposure of the Black Creek formation on the Pee Dee River is at Burches Ferry, 9 miles south of Mars Bluff Ferry, where at low water 4 $1 \frac{1}{2}$ feet of dark-gray laminated sand and clay is revealed, unconformably overlain by 10 feet of fossiliferous Peedee sand.

\section{MARION COUNTY}

Hodge's mill (28).-The Snow Hill marl member of the Black Creek formation is exposed in a bluff at the site of Hodge's old mill, 200 feet west of the Nichols-Galivants Ferry road, half a mile north of its junction with the Sandy Bluff road. The lower 5 feet consists of tough dark-gray sand enclosing fragments of lignite and soft shells. Iridescent fragments of nautiloid shells are abundant. The upper part is laminated brown micaceous sand. Stephenson ${ }^{30}$ lists the following species from this locality:

\footnotetext{
w Stephenson, L. W., Cretaceous formations of North Carolina, part 1, Invertebrate fossils of the Upper Oretaceous formations: North Carolina Geol. Survey, vol. 5, pt. 1, table facing p. 38, 1923.
} 
Ostrea blackensis Stephenson

Ostrea sloani Stephenson

Ostrea plumosa Morton

Exogyra costata var. "spinosa" Stephenson (not E. spinosa Matheson)

Trigonia marionensis Stephenson

Veniella mullinensis Stephenson

Crassatellites roodensis Stephenson

Cardium dumosum Conrad

Cardium spillmani Conrad

Cyprimeria gabbi Stephenson?

Cyprimeria depressa Conrad

Aphrodina regia Conrad

Legumen concentricum Stephenson

Legumen carolinense Stephenson?

Leptosolen biplicatus Conrad

Pholadidea fragilis Stephenson.

Buck Swamp (29).-Very fine blue sand containing impressions of shells crops out in the bed of a branch of Buck Swamp at an old mill on the Mullins road 3 miles southeast of Smithboro. It is overlain by Pleistocene sand and gravel. The fossiliferous sand is tentatively referred to the Snow Hill marl member of the Black Creek formation.

SUMTTRR COUNTY

Rocky Point (30).-Sloan ${ }^{37}$ and Berry ${ }^{88}$ record 6 to 8 feet of brownish laminated clay with partings of light-gray sand unconformably overlying upper cretaceous deposits at Rocky Point, on the eastern scarp of Wateree Swamp half a mile northeast of Sumter Junction. They referred this clay to the Eocene, and it is here tentatively correlated with the Black Mingo formation, although it may be of Black Creek (Upper Cretaceous) age.

Wedgefield (31).- A good section of beds that are tentatively referred to the Black Creek formation is exposed in the cuts of the Atlantic Coast Line Railroad, beginning at Wedgefield and extending westward 1 mile beyond the station. Beds 1 and 2 of the following section are disclosed by a short cut 1 mile from the station (see pl. 13, $A$ ), and their precise stratigraphic position with reference to the upper part of the section, which was measured in a long cut separated from the first by an interval in which there are no exposures, is unknown. Bed 3 may be partly equivalent to bed 2, or its base may be a little higher than the top of bed 2 .

w Sloan, Earle, op. cit. (Catalogue), p. 360.

u Berry, E. W., The Upper Cretaceous and Eocene fioras of South Carolina and Georgia: U. 8. Geol. Burvey Prof. Paper 84, p. 9, 1914. 


\section{Section in railroad cuts west of Wedgefield}

Black Mingo? formation; possibly Brandywine formation (Eocene? or Pleistocene):

6. Hard gray to yellow and red mottled sand with pebbles locally abundant; to top of cut............. 15-30

Unconformity.

Black Creek formation (Upper Cretaceous):

5. Brittle buff, slightly gritty clay resembling fuller's earth, merging with lower bed; thickness about.....

4. Fine drab compact sand weathering into friable, irregular lumps; thickness about... . . . . . . . . . . . . .

3. Coarse green glauconitic sand merging with overlying

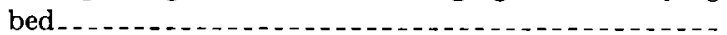

2. Alternating thin beds of coarse yellow sand, ferruginous sandstone, and brittle clay with laminae of fine micaceous sand exposed in cut 1 mile west of station;

Unconformity. thickness exposed about......................

Tuscaloosa formation (Upper Cretaceous):

1. White, purple, pink, gray, and yellow plastic sandy clay and coarse arkosic sand; thickness exposed about.

About 100 yards east of the point where beds 3, 4, and 5 were measured, bed 4 is steel-gray on the fresh surface but yellowish gray on weathered surfaces. The contact between the fresh and the weathered portions is sharp and irregular and might at first sight be mistaken for an unconformity. Both fresh and weathered parts enclose many round, shotlike, hard, brittle concretionary lumps that taste of alum.

Bed 6 varies from faintly mottled pale pink and gray to a uniform brilliant brick-red hue, the shade depending upon the degree of oxidation. Other facies are mottled yellow and pale yellow. Pebbles are locally abundant and are customarily distributed in lenticular zones. Where beds 4 and 5 are absent bed 6 rests directly upon bed 3. It is exposed continuously to the east end of the cut, near Wedgefield, and extends northward upon the High Hills of Santee.

\section{PEEDEE FORMATION}

GENRRAL CHARACTER

The Peedee formation is the highest and youngest of the Upper Cretaceous formations of South Carolina. It was first described under the name "Peedee bed" 39 by Ruffin, in 1843. Sloan ${ }^{40}$ called it the + "Burches Ferry phase" (also "marl") and applied the name $f$ "Pee Dee phase" (also "marl") to deposits of Miocene age. 
The Peedee formation consists chiefly of gray sandy marl interbedded with thin ledges of hard marlstone. It contains a characteristic Upper Cretaceous fauna, the most conspicuous species of which is Exogyra costata. Cuttings from a deep well at Charleston indicate that the formation is at least 800 feet thick in South Carolina.

In spite of its considerable thickness, outcrops of the Peedee formation are restricted to small areas along watercourses. Between streams the formation is nearly everywhere concealed by thin Eocene, Miocene, Pliocene, or Pleistocene deposits. The best exposures are on the Pee Dee River (from which the formation received its name) hetween Burches Ferry (32), which may be considered the type locality, and Yauhannah Ferry (44). The formation also crops out on or near Jeffreys Creek, the Lynches River, Black Mingo Creek, the Black River, and the Waccamaw River and beneath the sea. The known outcrops in South Carolina are all in Florence, Williamsburg, Horry, and Georgetown Counties. The Peedee formation is more completely developed in North Carolina, ${ }^{41}$ where it includes basal beds (the Exogyra cancellata zone) that are missing in South Carolina.

\section{FLORENCE COUNTY}

Burches Ferry (32).- Exposures of the Peedee formation on the Pee Dee River begin at Burches Ferry, 9 miles south of Mars Bluff and 88 miles above Georgetown, where the Peedee formation rests unconformably upon the Black Creek formation. The section is as follows:

\section{Section at Burches Ferry}

2. Peedee formation: Tough dark-gray calcareous sand and ledges of gray marlstone. Belemnitella americana and Exogyra costata very abundant; Anomia argentaria and other mollusks present. The base is slightly irregular and contains a few rounded pebbles of chert.......... Unconformity.

1. Black Creek formation: Dark-gray laminated sand and clay. No fossils seen. Exposed at low water........

Feet

The beds containing Exogyra cancellata, which in North Carolina form the base of the Peedee formation, are absent at Burches Ferry, and the upper part of the Peedee formation is there in contact with the Black Creek formation. Since the days of Tuomey Burches Ferry has been noted for the great profusion of guards of Belemnitella

1 Stephenson, L. W., The Cretaceous formations of North Carolina, pt. 1, Invertebrate fossils of the Upper Cretaceous formations: North Carolina Geol. and Econ. Survey, vol. 5, pp. 11-13, 1923. 
in the Peedee formation. Stephenson lists ${ }^{42}$ the following mollusks from Burches Ferry:

Ostrea tecticosta Gabb

Exogyra costata Say

Liopistha protexta Conrad Aphrodina tippana Conrad

Turritella vertebroides Morton
Belemnitella americana (Morton)

Belemnitella americans var. burchesensis Stephenson

Belemnitella abbreviata Stephenson

Orum (33).-The following section was observed on the road from Mars Bluff to Poston, 141/2 miles southwest of Florence and 3 miles northwest of Burches Ferry:

\section{Pleistocene:}

\section{Section one-fourth mile north of Orum}

3. Coarse gray and with fine gravel at the base. No sharp line of separation between this bed and bed 2 . To top of hill, about.

Eocene (Black Mingo formation):

2. Fine light-gray and containing slaks of silicified shell rock. No determinable fossils seen................ 5

Unconformity.

Upper Cretaceous (Peedee formation):

1. Fine-grained light-gray sandy marl with hard ledges at the base; fine dark-gray argillaceons sandy marl at top. Shells abundant throughout; Exogyra costata in upper part. To water level in drain .............

The section just described was probably measured at nearly the same place as the following section, adapted from Sloan, ${ }^{43}$ which, however, extends downward along a stream to low-water mark in Jeffreys Creek:

\section{Section at Myers Hill \\ [Adapted from Sloan]}

Wicomico formation (Pleistocene):

8. Sandy loam (altitude about 81 feet above mean low tide).

7. Red clay .

Black Mingo formation (Eocene):

6. White stratified coarse-and fine-grained sands enclosing dense silicified slabs containing casts of Venericardia planicosta. Exposed by highway south of dwelling-

Peedee formation (Upper Cretaceous):

5. Soft yellow marl including very hard discontinuous ledges. The soft marl contains Exogyra costata, Belemnitella americana, etc. Exposed by highway

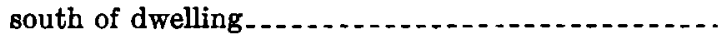

- Stephenson, L. W., op. cit., table facing p. 38.

u Sloan, Earle, op. cit. (Catalogue), p. 310. 
Section at Myers Hill-Continued

Peedee formation-Continued.

Feet

4. Green-gray, moderately compact marl enclosing large numbers of Exogyra costata, Crenella serica, Belem-

Unconformity. nitella americana, etc. A layer of pebbles at the base_ 23

Black Creek formation (Upper Cretaceoug):

3. Stratified black shale

2. Coarse sands . . .

1. Concealed to low-water level of Jeffreys Creek...... 5

Cains Landing (33).- The following section of the Peedee formation at Cains Landing, Pee Dee River, 1 mile below Burches Ferry, is also adapted from Sloan: ${ }^{44}$

\section{Section of Peedee formation at Cains Landing}

[Adapted from Sloan]

7. Green to drab plastic argillaceous marl

6. Layer of calcareous nodules.......... .5

5. Drab to black marl enclosing 2-inch calcareous nodules_- 3

4. Layer of shells cemented very hard with limonite; some shells coated with a drusy layer of pyrite.......... . 6

3. Gray-green marl containing Exogyra costata and Belemnitella americana, the upper portion very hard; interior of some shells lined with small crystals of pyrite........ 42

2. Hard, crystalline green-gray marl.................. 1.2

1. Soft gray-green marl

Dewitts Bluff (34).-At the lower end of Dewitts Bluff (pl. 13, B), 5 or 6 miles below Burches Ferry, about 10 feet of sparingly fossiliferous dark-green compact micaceous clay of the Peedee formation is exposed beneath yellow and black cross-bedded sands of Tertiary (perhaps Eocene) and Pleistocene age. Ostrea tecticosta Gabb and Pecten simplicius Conrad have been collected here.

Stones Landing (35).-Sloan ${ }^{45}$ records marl of the Peedee formation at water level beneath Miocene marls at Stones Landing, Pee Dee River, 4/2 miles below Dewitts Bluff.

Davis Landing (96).- The Peedee formation, consisting of dark bluish-gray argillaceous calcareous sand containing hard ledges in the upper part, rises 23 feet above low water in the Pee Dee River at Davis Landing, 72 miles above Georgetown. It is overlain unconformably by fossiliferous Miocene marl. Stephenson ${ }^{\text {to }}$ lists the

u Sloan, Earle, op. cit. (Catslogue), p. 312.

4 Idem, pp. 316-316.

to Stephenson, L. W., op. cit., table facing p. 38. 
following species of Cretaceous mollusks from the Peedee formation at this place:

Ostrea tecticosta Gabb

Gryphaea sp.

Exogyra costata Say

Pecten simplicius Conrad

Lima acutilineata Conrad
Anomia argentaria Morton

Crenella serica Conrad

Veniella conradi (Morton)

Sphenodiscus lobatus var. allisonensis Stephenson?

Allison Ferry (37).-A bluff near Allison Ferry, on the Pee Dee River, 11/4 miles northeast of Poston, yielded the following species of mollusks from the Peedee formation, which were identified by Stephenson: Exogyra costata Say, Anomia argentaria Morton, Veniella conradi (Morton)?, and Sphenodiscus lobatus var. allisonensis Stephenson.

Sparrow Swamp (38).-Tuomey ${ }^{47}$ describes an outcrop of the Peedee formation at Effinghams Mills, on Sparrow Swamp near its junction with Lynches Creek, as follows:

It forms the banks of the stream to the height of 4 or 5 feet and extends across the swamp at the mill. The bed is composed principally of a poor, siliceous marl, with irregular bands of marlstone running through it. The most common of all Cretaceous fossils, Exogyra costata, abounds here. I also found Trigonia thoracica and another undescribed species. It is highly probable that the channel of the creek, like that of the Pee Dee, is cut in this formation, for it may be traced some miles lower down. It appears again as the creek approaches the river, and at its mouth it rises into beds of considerable thickness.

Lynches River.-Sloan ${ }^{48}$ lists 4 feet of green-gray granular, smoothtextured marl with indurated layers containing Exogyra costata and other fossils, overlain by 3 feet of smooth black laminated soft shale, at Effingham Bridge, Lynches River, 0.2 mile west of Old Effingham. He also found it on the eastern (left) bank of the Lynches River below the Atlantic Coast Line Railroad bridge, 1 mile south of Effingham station. The following section is based upon Sloan's description: ${ }^{49}$

\section{Section on Lynches River below Atlantic Coast Line Railroad bridge}

Sunderland formation (Pleistocene):

7. White sand.

6. White and pink arenaceous clay $\ldots \ldots \ldots$

Black Mingo (?) formation (Eocene):

5. Fine-grained stratified sand, banded in horizontal zones of white, pink, salmon-colored, and yellow, some bands as much as 2 feet thick; dark chocolatecolored clayey sand along the bottom...........

4. Purple clay and water-bearing sand................ 11

17 Tuomey, Michael, Report on the geology of South Carolina, pp. 137-138, 1848.

a Sloan, Earle, op. cit. (Catalogue), p. 323.

"Idem, p. 324. 
Section on Lynches River below Atlantic Coast Line Railroad bridge-Continued

Peedee formation (Upper Cretaceous):

3. Gray marl rising 14 feet above level of low water in Feet river. Penetrated in artesian well............ 28

Black Creek formation (Upper Cretaceous):

2. Soft black sticky clay. Penetrated in artesian well _. 102 Tuscaloosa formation (Upper Cretaceous):

1. Sand containing water under sufficient pressure to raise it 50 feet above low water in Lynches River.

Sloan ${ }^{50}$ also reports about 10 feet of dark-green or blue soft marl on the Lynches River at Ards Bluff, 12.5 miles east of Lake City, and at Bartells Landing, 4 miles below Ards Bluff.

Lynches Lake.-Tuomey ${ }^{51}$ states that the Peedee formation is present on Lynches Lake, but does not mention any specific locality.

\section{WILLIAMSBDRG COUNTY}

Black Mingo Creek (39).-Tuomey ${ }^{81}$ and Sloan ${ }^{52}$ report the presence of the Peedee formation on Black Mingo Creek near Indiantown, 12.5 miles S. $55^{\circ}$ E. of Lake City. Sloan describes it as hard, harsh dark gray-green marl emerging a few feet above low tide and containing Exogyra costata and Turritella vertebroides.

County line road (40).-At a spring 100 yards northwest of the county line road, about $1 \%$ miles south of Rhems, there is a ledge of hard gray limestone containing many oyster shells. It closely resembles rock at Upper Browns Ferry and is referred to the Peedee formation.

Murrays Ferry road (41).- Sand containing fossil shells is reported to have been exposed many years ago at an old mill west of the Murrays Ferry road, 0.7 mile south of the Santee River road. Beneath the sand there is said to be about 1 foot of a blue substance (probably glauconitic sand or marl) containing many small shark teeth. These beds may be of Upper Cretaceous age (Peedee formation or the upper part of the Black Creek formation), or they may be Eocene (Black Mingo). The site of the mill is still marked by the ruins of the dam, but the fossiliferous materials are no longer visible.

\section{GEORGETOWN COUNTY}

Smiths Mills (42).-According to Sloan ${ }^{53}$ the Peedee formation rises $6 y_{2}$ feet above low water in the Pee Dee River at Smiths Mills, at the northern corner of Georgetown County.

sloan, Earle, op. cit. (Catalogue), pp. 325-326.

"Tuomey, Michael, op. cit., p. 138.

"Sloan, Earle, op. cit. (Catalogue), p. 326.

"Idem, p. 318. 
Petersfield (43).--Sloan ${ }^{54}$ describes 7 feet of green-black marl of the Peedee formation at Petersfield, 28 miles by water above the head of Winyah Bay.

Yauhannah(44) and Topsaw (45).-According to Sloan ${ }^{54}$ the Peedee formation is visible at extremely low water on the Pee Dee River at Yauhannah Ferry and Topsaw Landing. The strip exposed must be very narrow, for Pliocene shell marl crops out between tides at Yauhannah Ferry.

Black River.-Exposures of the Peedee formation are found at intervals along the Black River from Pea House Ferry (Georgetown waterworks), 6 miles (airline distance) above the mouth of the Black Mingo Creek, to Lower Browns Ferry, 1\%: miles below the creek. At Pea House Ferry (46) one or two ledges of hard gray siliceous limestone are exposed near water level in a bluff on the left bank above the ferry. Sloan ${ }^{55}$ reports Cretaceous marl at low-water mark at Perkins Landing (47), 3 miles southwest of the mouth of Black Mingo Creek. Sections at Upper and Lower Browns Ferry follow:

Section on left bank of Black River at Upper Browns Ferry (48)

Black Mingo (?) formation (Eocene?):

4. Coarse arkosic sand and gravel with pebbles of quartz and feldspar and a few fragments of oyster shells; laminated gray plastic clay in upper part. To top

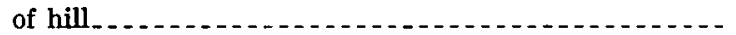

Unconformity.

Peedee formation (Upper Cretaceous) :

3. Fine yellow sand with soft shells by a soft bed. . . . . .

1. Very fine grained dark-gray marl loaded with soft shells. Underlain at level of low tide by a hard ledge ......- 
HORRY COUNTY

Waccamaw River.-The Waccamaw River cuts into the Peedee formation, but exposures are few and inconspicuous. The formation is overlain by shell marls of the Waccamaw formation (Pliocene) or by Pleistocene sand. The Peedee formation rises only a few feet above low tide. Exposures of the Peedee have been noted by Sloan ${ }^{56}$ near Wampee (50), at Harpers (51), at the mouth of Tilly Lake (52), at Nixons Landing (53), and at Hardee Ferry (54). Tuomey ${ }^{57}$ found Exogyra costata at Harpers Landing and on Tilly Lake. At Bucks sawmill (55) (now Bucksville), 9 miles below Conway, he found exposed at low water bands of siliceous slaty rocks, apparently without fossils, which he regarded as of Cretaceous age.

Atlantic Ocean.--Shells of Exogyra costata, shark teeth, and casts of gastropods are washed up in considerable abundance by the waves on the shore between Winyah Bay and the North Carolina line. Tuomey ${ }^{58}$ found them a few miles south of Little River Inlet, and Stephenson ${ }^{60}$ reports them from Myrtle Beach and Windy Hill (56). In 1933, W. F. Prouty found Cassidulus emmonsi at Myrtle Beach. This fact is of considerable significance, for it shows that, as might be suspected from the topography, marine erosion is taking place along the arcuate coast, and also that the cover of Tertiary and Pleistocene materials along that part of the shore is very thin.

\section{EOCENE SERIFS}

\section{CORREILATION}

In the Gulf States where the Eocene series is typically developed, it is divided into four major faunal units, to which the names "Midway" (lowest), "Wilcox", "Claiborne", and "Jackson" have long been applied. All of these except the Midway are present in South Carolina, but only the Jackson formation is completely represented. The Wilcox group is represented in South Carolina by the Black Mingo formation, which appears to correspond approximately to the Tuscahoma sand of Alabama; the Claiborne group hy the McBean formation, which is nearly equivalent to the Lisbon formation; and the Jackson formation by the Santee limestone, the Cooper marl, and the Barnwell sand. The correlation of the formations of South Carolina with the typical Gulf section and with the less complete sequence in the Atlantic States is shown in the accompanying table.

so Sloan, Earle, op. cit. (Catalogue), pp. 321-322.

"T Tuomey, Michael, op. cit., p. 134.

is Idem, p. 133.

so Stephenson, L. W., op. cit., p. 34. 
Correlation of the Eocene formations of the Atlantic and eastern Gulf States

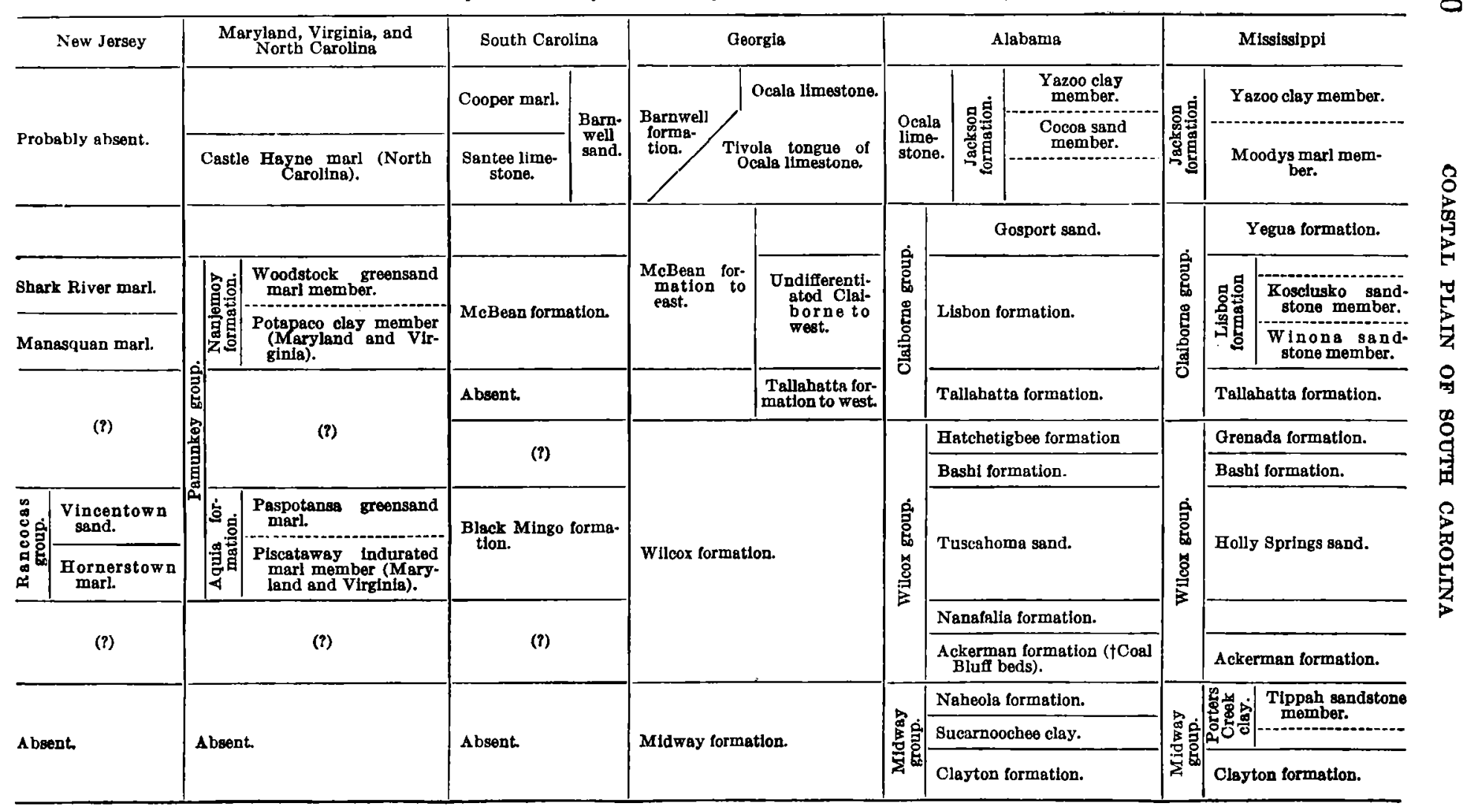


The name "Black Mingo shales", taken from Black Mingo Creek, a tributary of the Black River in Williamsburg and Georgetown Counties, S. C., was applied by Sloan ${ }^{60}$ in 1907 to laminated sandy shale exposed along the Black River from Brewington Lake (78), in Clarendon County, to the mouth of Black Mingo Creek, and up Black Mingo Creek to a point between Rhems and the General Marion Bridge. In 1908, he extended the name to a more comprehensive unit, his Black Mingo "phase", which included all the strata of lower Eocene age east of the Santee River. He recognized two main divisions of the Black Mingo "phase"-the †Upper Black Mingo and the †Lower Black Mingo. The †Upper Black Mingo included the $\nmid$ Lang Syne beds (tentatively), the †Williamsburg pseudobuhr, and the $\nmid$ Rhems shale. The †Lower Black Mingo retained the alternative name of "Black Mingo shale." In the present report, the name "Black Mingo formation" is applied to all the Eocene strata in South Carolina older than the McBean formation.

The †Rhems shale, placed by Sloan at the bottom of his †Upper Black Mingo, is gray to black brittle clay or shale exposed at Rhems Landing, on Black Mingo Creek. It appears not to differ materially from his †Lower Black Mingo or †Black Mingo shales, the type locality of which is Perkins Bluff, Black River, only 5 miles from Rhems.

The †Williamsburg pseudobuhr, named from Williamsburg County, was defined by Sloan ${ }^{61}$ in 1908 as

yellow-red sands which enclose a hard silicified ledge about 2 feet thick, in which casts of the Ostrea arrosis and the Venericardia planicosta occur. Characteristically exhibited at Dr. Boyd's place, 3 miles north of Salters and on scarp of Santee River, 1.5 miles south of Gourdin station.

Deposits of this kind make up the greater part of the Black Mingo formation and are widely distributed. They are interbedded, however, with dark clay, shale, or fuller's earth resembling the $\dagger$ Rhems shale.

Sloan's †Lang Syne beds, which rest unconformably upon the Tuscaloosa formation near Fort Motte, Calhoun County, are here tentatively referred to the Black Mingo formation.

The fCongaree phase of Sloan included shale, sand, and bubrstone that were regarded as intermediate in age between his †Warley Hill phase (McBean formation) and his Black Mingo "phase." The typical exposures are in the valley of the Congaree River. Some of

w Sloan, Earle, Handbook of South Carolina: South Carolina Dept. Agr., Commerce, and Immigration, p. 89, 1907; Catalogue of the mineral localities of South Carolina: South Carolina Geol. Survey, ser. 4, Bull. 2, p. 451, 1908.

"1 Sloan, Earie, op. cit. (Catalogue), p. 452. 
the deposits referred by Sloan to his †Congaree are proved by their fossils to belong to the Black Mingo formation, but others appear to be conformable with the McBean formation and are herein referred to it.

The Black Mingo formation lies at or near the surface in a broad belt that extends from Georgetown County to the High Hills of Santee in Sumter and Lee Counties. The red hills west of the Wateree, in Richland County, are also composed of the Black Mingo formation. It is unlikely that the formation extends far south of the Santee River, even under cover, although it may originally have been continuous with deposits of Wilcox age in Georgia.

The Black Mingo formation has had little influence on the development of the present topography except in Richland County and in the western parts of Sumter, and Lee Counties, where it upholds rather steep red hills that stand at a considerable altitude above the surrounding country. East or southeast of these hills, the surface of the Black Mingo formation was beveled off in the remote past to a peneplain upon which subsequent invasions of the sea left deposits. In the Congaree Valley the tough clays of the Black Mingo formation produce low falls in most of the smaller tributary streams.

The thickness of the Black Mingo formation visible at the surface probably nowhere exceeds 100 feet, and at most exposures it is only a few feet.

The scarcity of recognizable horizon markers makes it very difficult to determine the structure of the Black Mingo formation. The formation appears to lie nearly flat, with a very gentle slope to the south or southwest. The bottom of the formation does not furnish a reliable datum plane, because it is an uneven surface that owes its irregularities chiefly to erosion prior to the deposition of the Black Mingo and in very slight degree to warping.

The Black Mingo formation lies unconformably upon the Upper Cretaceous deposits. Contacts with the Peedee formation are visible in Georgetown County and with the Tuscaloosa formation in Sumter and adjoining counties. In Clarendon County and in the southern part of Sumter County, the Black Mingo overlies the Black Creek formation.

A small but characteristic group of fossils is widely distributed in the Black Mingo formation. Although the number of identifiable forms is not great and several of the species included are undescribed, the remainder constitute a fairly good basis for correlation. Particularly significant species are Coelohelia wagneriana Vaughan and Haimesiastraea conferta Vaughan, corals heretofore known only from the Wilcox and Midway groups of Alabama, also Ostrea arrosis Aldrich, referred by Aldrich to the Nanfalia formation of the Wilcox group. 
Sampit (57).-On the left bank of the Sampit River, 100 yards below the mouth of Spring Gully, 13/4 miles below Sampit Bridge, blue-green, very fine grained glauconitic rock is exposed. It is soft enough to be cut by the finger nail, but it is brittle and not plastic. It rises about to the level of high tide and extends below the surface an unknown distance. Sloan ${ }^{62}$ referred similar material found at Sampit Bridge to his Black Mingo "shales", and Vaughan ${ }^{63}$ saw obscure Eocene fossils in it.

Brick-red sand, perhaps of Eocene age, is exposed near one of the sources of Whites Creek on the road to Sampit, 3 miles northwest of Georgetown.

Perkins Bluff (58).--The type exposure of Sloan's †Lower Black Mingo is at Perkins Bluff, on the west (left) bank of the Black River, 3 miles (air-line distance) above the mouth of Black Mingo Creek. When visited in August 1917, the section was obscured, but lumps of fossiliferous limestone and brown shale were loose on the surface. No determinable fossils were seen.

The following section is adapted from the second of two recorded by Sloan: ${ }^{04}$

\section{Section at Perkins Bluff}

Black Mingo formation (Eocene) :

Feet

1

4. Bumrstone tains a hard ledge enclosing large bones and Eutre-

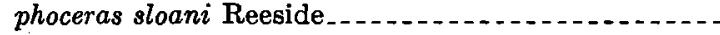

2. Compact red sand $\ldots \ldots$

Peedee formation (Upper Cretaceous) :

1. Marl, exposed at low tide.

Rhems (59).-The following section is exposed at Rhems Landing, on the west bank of Black Mingo Creek, $3 \frac{3}{4}$ miles (air-line distance) above its confluence with the Black River:

\section{Section at Rhems Landing}

Pamlico (?) formation (Pleistocene):

Feet

4. Fine yellow sandy loam; to flat..................

Black Mingo formation (Eocene):

3. Partly indurated, very fine white to yellow sand with white cement, probably calcareous.................

2. Fine-grained sugary sandstone

1. Dark-gray, nearly black brittle clay or shale containing Venericardia "planicosta", etc. Extends below tide; thickness above low water.

92 Sloan, Earle, op. cit. (Catalogue), p. 361.

as Vaughan, T. W., field notes, Dec. 17, 1907.

u Sloan, Earle, op. cit. (Catalogue), pp. 319, 360. 
Sloan ${ }^{68}$ reports silicified casts of shells from gulches in the vicinity of Rhems Landing.

County line road (60).-The following section is exposed at a bend in the road from Georgetown to Rhems at the boundary line between Georgetown and Williamsburg Counties, 1.2 miles south of Rhems and 3 miles northwest of Upper Browns Ferry:

Section of Black Mingo formation on County line road 1.2 miles south of Rhems

2. Reddish cross-bedded sand and gravel passing upward into Feet fine brick-red sand. Contains Turritella sp.?, Modulus sp., Ostrea arrosis Aldrich, and Venericardia sp. (station 7976)

Unconformity.

1. Brittle gray shale; to road fork

Choppee Creek (61).-Sand containing Black Mingo fossils is exposed at an old ferry on the north (left) bank of the Black River just above the mouth of Choppee Creek, 12 miles N. $10^{\circ} \mathrm{W}$. of Georgetown. The section is as follows:

Section on Black River above Choppee Creek

Pamlico (?) formation (Pleistocene): Sand and gravel to top of bluff, about.....................

Black Mingo formation (Eocene): Fine sand; at top is a ledge of slabby white to yellow sandstone. Loose on surface (station 7969) are Ostrea arrosis Aldrich, Modiolus alabamensis Aldrich?, Venericardia mingoensis Gardner and Bowles, Melina sp., Liotia sp., and undetermined species of several other genera. Extends above high tide about.......

Choppee Landing, Black Mingo Creek (62).-Ostrea arrosis, the characteristic oyster of the Black Mingo formation, is abundant at Choppee Landing, 1 mile above the mouth of Black Mingo Creek, where the following section was observed:

\section{Section at Choppee Landing}

Pleistocene (?): Yellowish argillaceous sand with gray laminated clay in the lower part and a few small pebbles at base; to top of bluff -

Eocene (Black Mingo formation): Fine reddish-yellow argillaceous sand with a 1-foot bed of broken oyster shells (Ostrea arrosis Aldrich, station 7975) at top; to water level in Black

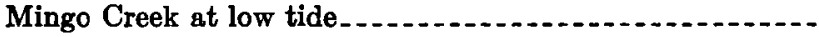

\section{WHLIAMSBORG CODNTT}

Suttons (63).- Sand of the Black Mingo formation is exposed on the roadside at Rowe's Mill Branch, 2 miles east of Suttons. The section follows:

as Sloan, Earie, op. cit. (Catalogue), p. 360. 
Section of Black Mingo formation at Rowe's Mill Branch

2. Fine yellow glauconitic sand with fossils (station 7982) _... 3

1. Fine slate-colored laminated sand, above water

Bed 2 contains Bryozoa, Ostrea arrosis Aldrich, an undescribed species of a new genus related to Anomia, and a new species of Pecten related to $P$. greggi Harris.

About 6 feet of tough gray to red argillaceous sand that appears to include some glauconite was observed on the same road 2.2 miles soutbeast of Rowe's Mill Branch (64).

Salters (65). - On the roadside 1.1 miles east of Salters silicified shells were found in fine gray to reddish sand that conformably overlies a 6-inch bed of light-gray fuller's earth. Beneath the fuller's earth is fine gray sand. The species collected here (station 7920) are Coelohelia wagneriana Vaughan, Haimesiastraea conferta Vaughan, Cucullaea transversa Rogers, Ostrea sp. (probably O. arrosis Aldrich), and undetermined species representing 10 or more genera.

The same bed appears on the opposite side of Thorntree Swamp, about 0.2 mile farther east, where it is unconformably overlain by coarser gray to red sand, and it is better exposed but less fossiliferous at the Lower Bridge over the Black River, 2.4 miles from Salters and 6.5 miles south of Kingstree. (See section at locality 67, p. 46.)

Kingstree (66).- Haimesiastraea conferta Vaughan, Ostrea arrosis Aldrich, and Turritella sp., fossils characteristic of the Black Mingo formation, were found on the main street in the town of Kingstree, near the highway bridge over the Black River (station 7921). They were collected in bed 3 of the following section:

\section{Section on Black River at Kingstree}

Black Mingo formation:

Feet

4. Sand in a matrix of gray clay; to top of hill

3. Yellow medium-grained sand containing laminae of semiplastic gray clay and a few fossils

2. Concealed

Black Mingo (?) formation:

1. Dark-gray to chocolate-colored fissile clay resembling fuller's earth and containing indistinct vegetable remains; closely resembles the Black Creek formation. Formerly exposed in river bank at Rock Hole, 200 yards below the wagon bridge, but now covered by backwater from a dam. ............................ (1) 
Lower Bridge (67).-An interesting section is exposed in the bluff on the right (south) bank of the Black River at the Lower Bridge, 6.5 miles by road south of Kingstree and 2.4 miles from Salters. The section follows:

Section at Lower Bridge, Black River

Penholoway (?) formation (Pleistocene?):

3. Coarse orange-colored sand with pebbles and broken shells at base; extends downward over bed 2 to bed 1 , the overlapping part cross-bedded; to top of hill, about . .

Unconformity.

Black Mingo formation (Eocene):

2. Very fine grained thin-bedded gray and red sand, weathering brick-red and yellow; appears to contain a little glauconite

Feet

1. Light-gray to dark slate-colored hard fuller's earth or shale; base concealed. A few loose slabs contain a 3-inch bed of silicified shells (not determinable). To low-water mark in Black River....

An attempt was made to exploit the fuller's earth of bed 1 commercially. Pits were opened near Salters and machinery installed, but the venture was not successful.

Mouzon Bridge (68).-At Mouzon Bridge, which spans the Black River between the mouths of Clap and Pudding Swamps, 8 miles above Kingstree, a stratum of flint containing indeterminable casts of shells crops out in the bed of the river. A little blue-green sand is exposed below the bridge.

The following section exposed in a large well 1.5 miles west of Mouzon Bridge is adapted from Sloan: ${ }^{86}$

Section in well 1.5 miles west of Mouzon Bridge

Wicomico (?) formation (Pleistocene):

Feet

4. Sandy loam

3. Yellow and red clay loam 4

Black Mingo formation (Eocene):

2. Yellow-gray granular mass of sands (elsewhere in this vicinity enclosing buhr-rock) ......................

1. Fuller's earth (shale); the lower part contains pyrites, the weathering of which in contact with the fuller's earth has produced an appreciable amount of aluminum sulphate

Hanging Rock (69).-At Hanging Rock, a projecting mossy ledge on the left bank of the Black River 1.1 miles southeast of Workman and 9.7 miles above Kingstree, greenish-gray sandy micaceous clay rises 3 feet above low water. No fossils have been found in it.

w Sloan, Earle, op. cit. (Catalogue), p. 359. 
Gourdin (70).-About 300 feet east of the Atlantic Coast Line Railroad at Santee Bluff signal station, 11/4 miles south of Gourdin, large springs of clear, cold water issue from beneath 15 feet of drab shale or fuller's earth. The base of the exposure is about 25 feet above sea level. The materials overlying the shale are concealed at the springs, but along the railroad and extending a few feet below the track is a bed of dirty-yellowish coarse gravel that appears to have been gray originally. The higher part of this bed is finer. It is probably a Pleistocene terrace deposit. Sloan ${ }^{67}$ reports 3 to 15 feet of red Eocene sand, doubtless the Black Mingo formation, enclosing silicified slabs preserving Venericardia "planicosta", immediately overlying the fuller's earth in this vicinity. The springs may mark the contact of the Black Mingo and the Peedee formation, which probably lies not far below the surface in this region.

Murrays Ferry road.-Fossils have been found in the Black Mingo formation at two places on the Murrays Ferry road between Kingstree and Heinemann. The collection from station 7923, east of Mill Swamp, 5.8 miles southwest of Kingstree (71), includes a coral, Murex sp., Natica sp., Leda sp., and Gervillia? sp. cf. Perna cornelliana Harris, found in gray to red argillaceous sand with lumps of fossiliferous chert. North of Bennett Swamp, at station 7922, 6.6 miles southwest of Kingstree and 5.5 miles north of Heinemann (72), Surcula? sp., Turritella sp., Natica sp., Venericardia "planicosta", Teredo? sp., and Ostrea arrosis Aldrich were found with lumps of shell rock in tough gray sand and clay.

At an old mill on the west side of the old Murrays Ferry road (41), 0.7 mile south of the Santee River road, shells are reported to have been found in sand many years ago. Beneath the sand there is said to be about 1 foot of blue material (probably glauconitic sand) containing many small shark teeth. The ruins of an old dam are still to be seen, but no exposures of fossiliferous sand are now visible.

Murrays Ferry Bridge (73).-At the north end of the approach to Murrays Ferry Bridge, fine micaceous sand is exposed in a pit west of United States Highway 52. At a depth of 7 feet below the surface the sand is consolidated into hard gray sandstone. No fossils were seen here.

Manning road (74).-About 10 feet of medium-fine to coarse red to gray sand containing poorly preserved fossils is exposed on the road from Kingstree to Manning about half a mile east of the Clarendon County line. Scattered upon the surface are lumps of fossiliferous chert resembling that at Tindall's Mill, 6 miles west of Manning.

" Sloan, Earle, op. cít. (Catalogue), p. 356. 
BERRELEY COUNTY

Murrays Ferry Bridge (75).-A large excavation east of United States Highway 52, at the south end of the approach to Murrays Ferry Bridge over the Santee River, 18 miles north of Moncks Corner, exposes fine gray to red argillaceous micaceous sand overlain conformably by coarse sand containing angular pebbles. Both beds contain fragments of Ostrea arrosis. Sand from this pit was used in filling the approach to the bridge. The exposure is 10 feet or more high.

St. Stephen (76).-Gray to red micaceous sand containing fragments of oysters is exposed at intervals along the road to Jamestown for 3 miles or more east of St. Stephen.

Bonneau (77).-Coarse sand and gravel containing a few fragments of shells was noted about 1 mile north or northeast of Bonneau.

\section{CLARENDON COUNTY}

Brewington Lake (78).- The following section was measured along the road from the vicinity of the bridge at Brewington Lake southward to Brewington Church:

\section{Section on roadside north of Brewington Church}

Wicomico (?) formation (Pleistocene?):

Feet

4. Fine gray argillaceous sand, slightly mottled with red, passing into yellow loam at top; to top of hill at Brewington Church, about.................... 10

Black Mingo formation (Eocene):

3. Fine orange sand, about

2. Rather coarse reddish-yellow sand with a 1-foot oyster bed at base containing Mytilus n. sp. and Ostrea arrosis Aldrich (station 7981)

1. Dark-gray or slate-colored fissile shale containing sand laminae; extends above water level. ...............

Brunson's mill (79).--According to Sloan, ${ }^{68}$ a pit at Brunson's sawmill, 5.5 miles N. $67^{\circ}$ E. of Wilson, exposes 6 feet of red argillaceous sand enclosing fossiliferous buhr-rock, overlying 15 feet of stratified fuller's earth.

Wilson (80).--Sloan ${ }^{69}$ also records 18 feet of light-gray laminated shale interbedded with fine micaceous sand in the valley of Deep Creek near Wilson, 1.2 miles east (?) of the Atlantic Coast Line Railroad.

Manning (81).-A foot or two of shale has been uncovered in the bottom of a drainage ditch near the edge of the swamp southeast of Manning. The shale is chocolate-colored when wet but becomes light gray and very adhesive to the tongue on drying. It is brittle and of low specific gravity and contains thin partings of sand. It is overlain by 10 feet of tough gray coarse sand and gravel. Sloan

Aloan, Earle, op. cit. (Catalogue), p. 361.

or Idem, p. 361. 
and Vaughan collected Calyptraea aperta, Adeorbis sp., Ostrea sp. (probably 0 . arrosis), and Venericardia "planicosta" from beds above the shale in a ditch on the northeast edge of Manning (station 5254).

Tindall's mill (82).- Silicified shells from the Black Mingo formation were found in the bed of Sammy Swamp at Tindall's old water mill, on the road from Manning to Paxville. The shells are loose or in lumps of sandstone and chert lying upon greenish-black hackly clay that forms the bed of the creek. The list of species follows:

7964. Tindall's mill, Sammy Swamp, on road from Manning to Paxville 6 miles west of Manning; C. Wythe Cooke, collector, 1917:

Pseudoliva n. sp.?

Calyptraphorus? ef. C. jacksoni Clark

Calyptraphorus sp.

Mitrella? sp.

Turritella sp.

Natica sp.

Ostrea arrosis Aldrich

Venericardia planicosta (Lamarck) var.

Venericardia aff. V. alticostata Conrad

Spring Grove Creek (83).--Many lumps of fossiliferous chert, apparently from the Black Mingo formation, were used about an old mill on Spring Grove Creek, 11/4 miles south of Rimini. Nearby is a 1-foot ledge of hard fine white sandstone overlain by 2 feet of flaky sandy clay, which in turn is overlain by coarse gray gravel strewn with large blocks of white sandstone and a few fragments of fossiliferous chert. Above the gravel is fine tough gray argillaceous micaceous sand weathering red.

A pile of fossiliferous chert was also noted beside the River Road 4 miles south of Spring Grove Creek. Its source was doubtless not far away.

Wyboo Swamp (84).-Unconformably underlying what appears to be a near-shore facies of the Santee limestone, 5 feet of chocolatecolored crumbly clay or soft shale is visible on the Santee road east of Wyboo Swamp, 11 miles south of Manning. The base of the exposure is 10 feet above water level in Wyboo Swamp. This deposit is tentatively correlated with the Black Mingo formation, although it may be the Black Creek. A section is recorded on page 79.

Wrights Bluff (85).-According to Sloan, ${ }^{70}$ a 13 -foot bluff on the east bank of the Santee River shows the following section:

Section at Wrights Bluff

3. Drab fuller's earth Feet

2. Soft fuller's earth

1. Plastic yellow clay

ro SIosn, Earie, op. cit. (Catalogue), pp. 355-356. 
Nearly all of Sumter County except the western border is underlain by the Black Mingo formation, but most of the part east of the High Hills of Santee is covered by younger deposits. Fossils have been found in the Black Mingo at several places, particularly in the northern part of the area, but recognizable species are few. In this region the color of the Black Mingo ranges from gray to brick-red, depending upon the extent of weathering. The fresher parts are generally mottled or splotched with pink or yellow, but the more weathered parts are uniform in color and present a massive appearance. Small pebbles are locally abundant, and pebbles 2 or 3 inches in diameter are occasionally found. The bulk of the formation, however, is sand mixed with enough clay to make good hard roads. There is a 30-foot bed of fuller's earth in the southern part of the county, and thinner beds near Stateburg.

Fuller's Earth Creek (86).-Where the River Road crosses Fuller's Earth Creek, 4 miles north-northwest of Pinewood, 30 feet of gray shale is overlain by a ledge of hard silicified sandstone containing fossil shells. The rock is evidently the same as that exposed on the River Road 11/4 miles farther south, which contains Ostrea arrosis, Venericardia "planicosta", Turritella mortoni, a coral, and several other poorly preserved mollusks. The shale as well as the sandstone is probably part of the Black Mingo formation. The sandstone is overlain by pebbly sand.

Wedgefield (31).-The cut of the Atlantic Coast Line Railroad at Wedgefield exposes 15 to 30 feet of hard gray to yellow and red mottled sand. It ranges from faintly mottled pale pink and gray to a uniform brilliant brick red, the color depending upon the degree of oxidation. Other facies are mottled yellow and pale yellow. Pebbles are locally abundant and are customarily distributed in lenticular zones. This bed may be either the Black Mingo formation or the Brandywine (Pleistocene) formation. It rests unconformably upon brittle clay that is tentatively correlated with the Black Creek formation.

Wedgefield-Camden road.-Indeterminable fragments of oyster shells and a ribbed pelecypod, probably Venericardia "planicosta", are embedded in brilliant brick-red argillaceous sand with zones of pebbles on the Wedgefield-Camden road 1.1 miles north of Wedgefield (87). A similar stratum of shells was noted 0.6 mile farther north.

Gullies west of the Camden road 21/4 miles north of Wedgefield (88) expose a ledge of hard, brittle dark-gray clay about 3 feet thick, underlain by soft, porous, tough sandstone and overlain by soft fine-grained sandstone and gray fuller's earth. Associated with these are loose slabs of hard gray sandstone composed of coarse grains of dark quartz in white clay, which contain indeterminable impressions of shells. 
The precise position in the section of this fossiliferous sandstone is unknown.

At Moore's Spring, 2.2 miles north of Wedgefield and 200 feet west of the Stateburg highway (Camden road), according to Sloan, ${ }^{71}$ "19 feet of laminated shales (Eocene) occur interstratified with seams of sand and mica; shale encloses casts of Venericardia planicosta. Upper surface of shale 48 feet above Wedgefield railway station."

Stateburg (89).- Shale or fuller's earth crops out on the hillside west of and 35 feet lower than the Camden road, half a mile southeast of Holy Cross Episcopal Church and 4.1 miles north of the railway station at Wedgefield. On the slopes of the hill about 20 feet below the exposure of fuller's earth are numerous lumps of chert containing Haimesiastraea conferta Vaughan and indeterminable species of Corbula and Turritella. No exposures other than that of the fuller's earth were seen, nor were any lumps of chert found above the fuller's earth.

In a gully east of the road at Holy Cross Church 10 feet of gray brittle clay with thin sand beds is overlain, apparently conformably, by 30 feet of yellow sand that weathers bright red and contains thin beds of brittle clay near the base.

Catchall (90).- Red argillaceous sand like that north of Wedgefield except that pebbles are rarer is exposed on the descent to the valley of the Wateree River 2 miles west of Catchall and 4 miles northeast of Claremont. The sand contains greenish lumps, which is also a characteristic of the Wedgefield locality, and poorly preserved shells, none of which have been specifically identified. The list of genera follows:

7983. Roadside, 2 miles west of Catchall; C. Wythe Cooke, collector, 1917:

Madrepora sp.

Mesalia? n. sp.?

Turritella, $2 \mathrm{sp.}$

Turritella sp.; also at Salters, station 7920.

Venericardia sp.

Crassatellites sp.

Echinoid, fragment.

Pocalla Springs (91).--In digging the foundations for the county bridge over Pocotaligo Swamp at Pocalla Springs, on the road to Manning 3 miles south of Sumter, fragments of silicified shell rock are said to have been found at water level. This rock may represent the Black Mingo formation.

\section{IEE COUNTY}

The Black Mingo formation in Lee County consists chiefly of brick-red argillaceous sand similar to that underlying the High Hills of Santee in Sumter County. No fossils have been found in it. The sand rests upon the eroded surface of the Tuscaloosa formation.

n Bloan, Earle, op. cit. (Catslogue), p. 353. 
The proximity of the contact is generally marked by an abundance of ferruginous sandstone or limonite.

RICELAND COONTY

Several outliers of the Black Mingo formation have been found in Richland County. They make red hills like the High Hills of Santee, on the opposite side of the Wateree River, which are similar in geologic composition and topography. The Black Mingo consists chiefly of massive red argillaceous pebbly sand. Pebbles are most abundant in a conglomeratic layer at the base of the formation and in higher zones or lenses, but some pebbles are distributed throughout it without regard to bedding planes.

Good Hope Church (92).-Fossils have been found in the Black Mingo formation at only one locality in Richland County. In gullies heading east of the road from Good Hope Church to Leesburg, 0.2 mile north of the Garners Ferry road and 4.6 miles north of Eastover, very obscure traces of marine fossils were seen 40 feet below the level of the road, about 360 feet above sea level. The shells are embedded in massive red and mottled red and yellowish argillaceous sand containing thin bands of white clay concretions. Near the top of the exposure are large pebbles, and at the bottom is loose yellowish coarse sand. The strata exposed here closely resemble the outcrops of the Black Mingo formation on the Stateburg road in Sumter County, which is only 10 miles away, and there is little doubt that both are of the same age.

Milepost 19 (93).-The following section was measured along the Garners Ferry road from a point 0.7 mile east of Toms Creek to the top of the hill at milepost 19 (east of Columbia), 1 mile from the creek. The altitude of the Cretaceous-Eocene contact is about 320 feet above sea level.

\section{Section 19 miles east of Columbia}

Black Mingo formation (Eocene):

4. Fine massive yellowish sand with a few scattered pebbles in the upper part......... 30

3. Coarser pebbly red sand with limonitic crusts; merges into the overlying bed....................... 5

2. Coarse yellow limonitic pebbly sand with irregular deposits of limonite, passing upward into fine laminated red sand and plastic gray clay ................

Unconformity.

Tuscaloosa formation (Cretaceous):

1. Irregularly bedded white sandy clay.

Toms Creek (94).-What appears to be the Cretaceous-Eocene contact is exposed on the Garners Ferry road 0.2 mile east of Toms Creek, about 255 feet above sea level. The strata exposed are fine 
micaceous arkosic sand overlain by coarse red argillaceous sand containing pebbles and balls of kaolin at the base.

Bellewood School (95).-Brick-red argillaceous sand containing a fow pebbles and resembling the Black Mingo formation near Wedgefield is exposed to a thickness of about 65 feet at Bellewood School, on the Garners Ferry road 2 miles west of Toms Creek. The hills rise from an altitude of about 280 or 290 feet at the crossroads to nearly 450 feet within 2 miles north of Bellewood School.

Horrell Hill (96).--Horrell Hill (altitude about 410 feet), 13 miles east of Columbia, is composed of orange and red pebbly sand, probably of Black Mingo age. The contact of the Black Mingo with the Tuscaloosa formation is exposed at an altitude of about 345 feet on the Garners Ferry road 0.2 mile east of the crossroads at old Horrell post office. The pits of the Interstate Clay Co., working kaolin of the Tuscaloosa formation, are visible about half a mile across country toward the southeast and about 70 feet lower.

\section{CALHOUN COUNTY}

Lang Syne plantation (16).-On the Lang Syne plantation, 13/2 miles east of Fort Motte, there are patches of the Black Mingo formation in the old valleys of the Cretaceous surface, but in nearby areas where the Cretaceous surface is higher the Black Mingo is absent.

The †Lang Syne beds of Sloan, ${ }^{72}$ consisting of fine-grained black carbonaceous sand with an indurated limonitic ledge forming a waterfall, are exposed at a hydraulic ram at the mouth of Tomb Field Gully, a ravine heading near an old private cemetery. Below the ram gray to black sandy clay, carbonaceous in places and merging laterally into loose black carbonaceous sand, is exposed in the bed of the stream. The geology of the Lang Syne plantation is described more fully on page 69 .

Bates Mill (97).-The unconformity separating the McBean formation from the Black Mingo formation was exposed in 1908 on the road east of Bates Mill, on High Hill Creek 3 miles north-northwest of St. Matthews (pl. 14, A). The following section is adapted from the unpublished field notes of L. W. Stephenson made February 17, 1908. The locality may be the same as that described by Sloan. ${ }^{73}$

Section at Bates Mill

McBean formation (Eocene):

8. Decomposed glauconitic sand $\ldots \ldots \ldots$

7. Ferruginous laminated shale......... 1

6. Interlaminated thin layers of shale and sand ...... 2 Unconformity.

"Sloan, Earle, op. cit. (Catalogue), p. 355.

"Idem, pp. 353-354. 


\section{Section at Bates Mill-Continued}

Black Mingo formation (Eocene):

Feet

5. Laminated slate-colored clay or shale, weathering white, interlaminated with coarse gray sandy layers, some of which are several feet in thickness. In places the shale contains fine pores, making the material finely cellular. One of the eandy beds contains Ostrea arrosis, Turritella sp., a coral, etc........... 10

4. Dark-green glauconitic sand.

3. Dark compact laminated clay, lignitic and containing poorly preserved leaves and grasses and iron pyrites.-

2. Clay similar to bed 3 but lighter-colored........... 3

Unconformity.

Tuscaloosa formation (Upper Cretaceous):

1. Very light clay with waxy luster grading downward into coarse arkosic sands; to base of hill

High Hill Creek (97).-The relations of the Black Mingo formation to the McBean and Tuscaloosa formations were well shown in 1917 on the road leading down to High Hill Creek near Calvary Church, 4.5 miles by road north of St. Matthews. Bates Mill was probably near this place.

\section{Section 4.5 miles north of St. Matthews}

McBean formation (Eocene):

8. Coarse red argillaceous sand, finer toward top. To top of hill east of High Hill Creek, about._.

7. Pale greenish-yellow laminated clay, weathering red... 2

6. Massive coarse red pebbly sand with inclusions of fine gray sandstone 3 inches in diameter......... 14

Probable unconformity.

Black Mingo formation (Eocene):

5. Soft gray to reddish argillaceous sand, perhaps an old soil derived from bed 4

4. Light-gray porous brittle clay of low specific gravity and conchoidal fracture like fuller's earth; upper surface irregular

3. Fine dark-gray, slightly glauconitic sand containing phosphatic nodules.

2. Very dark blue, friable clay containing fragments of leaves and roots......

Unconformity.

Tuscaloosa formation (Upper Cretaceous):

1. Coarse gray, somewhat micaceous, highly arkosic sand in a matrix of white clay. To water in High Hill

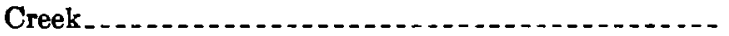




\section{MCBEAN FORMATION}

GENERAL CHARACTER

The McBean formation was so named by Veatch and Stephenson 74 from the town of $\mathrm{McBean}, \mathrm{Ga}$., and from McBean Creek, a tributary of the Savannah River. In the original description, the name was applied to a series of deposits extending from the Savannah River all the way across Georgia to the Chattahoochee River, but the use of the name in Georgia has since been restricted ${ }^{75}$ to the deposits of Claiborne age in the Savannah River drainage basin. The corresponding strata in South Carolina form part of the †Buhrstone formation of Tuomey, ${ }^{76}$ which includes practically all the siliceous Eocene deposits of the State. In 1898 Dall ${ }^{77}$ proposed the geographic name †"Orangeburg" as a substitute for the descriptive term $f$ "Buhrstone", designating as typical a locality in the old Orangeburg district (Lang Syne plantation, near Fort Mott, now in Calhoun County) at which Tuomey obtained several species of fossils. The name f"Orangeburg" has not been generally used by geologists, but it has since been applied by the United States Bureau of Soils to a series of soil types that is widely distributed and that is not restricted to any one geologic formation. The so-called $\dagger$ "Warley Hill phase", named by Sloan ${ }^{78}$ in 1907 and more fully described by him in 1908, is partly equivalent to the McBean formation, which was named 4 years later. Strict application of the rule of priority would require the use of the name " "Orangeburg" both in South Carolina and in Georgia, but the name "McBean" has become so firmly established in the literature and has been so precisely defined that any attempt to supplant it by its older rival seems inadvisable.

Throughout the greater part of the region in which it is exposed the McBean formation has completely overlapped the lower Eocene and rests upon the eroded surface of the Upper Cretaceous Tuscaloosa formation, but along the southwest side of the Congaree Valley the lower Eocene shale (Black Mingo formation) emerges from beneath the sands of the McBean formation. The McBean formation is separated from the underlying Black Mingo by an erosional uncon-

\footnotetext{
It Veatch, Otto, and Stephenson, L. W., Geology of the Cosstal Plain of Georgia: Georgia Geol. Survey Bull. 26, p. 237, 1911.

' Cooke, C. W., and Bhearer, H. K., Deposits of Claiborne and Jackson age in Georgia: U. S. Geol. Survey Prof. Paper 120, pp. 41-81, 1918.

70 Tuomey, Michael, Report on the geology of South Carolina, p. 143, 1848.

77 Dall, W. H., A table of North American Tertiary horizons, correlated with one another and with those of western Europe: U. S. Geol. Survey 18th Ann. Rept., pt. 2, p. 344, 1898.

is Bloan, Earle, Handbook of South Carolina, p. 90, South Carolina, Dept. Agr., Commerce, and Immigration, 1907; Catalogue of the mineral localities of Bouth Carolina: South Carolina Geol. Survey, ser. 4, Bull. 2,.pp. 467-459, 1908.
} 
formity. The McBean formation is overlain unconformably by the Santee limestone or by the Barnwell sand, both of Jackson age. The erosion that preceded the invasion of the Jackson sea appears to have removed much of the $\mathrm{McBean}$ formation south of the region in which it now lies at the surface, for it has not been recognized in cuttings from wells there.

The principal constituents of the McBean formation are fine- to medium-grained sand, thin beds of greenish glauconitic marl, laminated flaky clay, fuller's earth, and lenses of silicified limestone. The prevailing color of the unweathered material is light greenish yellow. The combination of fine greenish sand and flaky, nonplastic clay is especially characteristic. On weathered surfaces the color is usually red, owing to the oxidation of the iron-bearing minerals in the formation. Along the Savannah River the upper part of the McBean formation consists of hard gray calcareous sandy marl, but this facies appears not to persist along the outcrop toward the east, although a few small occurrences of similar material are known.

The maximum thickness of the McBean formation exposed in eastern Georgia is estimated at little more than 100 feet. $^{79}$ In South Carolina the formation appears to have about the same thickness.

Large collections of fossils from widely separated localities serve to establish rather close correlations with formations in other areas. The fauna, which is an assemblage of species living in moderately shallow water, chiefly mollusks, contains many species in common with the Lisbon formation of the Claiborne group of Alabama and Mississippi, the St. Maurice formation of Louisiana, and the Cook Mountain formation of Texas, and there can be little doubt that the McBean formation is of very nearly the same age as those formations. The best collection thus far obtained was made by Sloan near the mouth of McBean Creek in Georgia. A list containing 65 species from this locality, identified by T. W. Vaughan, was published by Veatch and Stephenson ${ }^{80}$ Representative collections have been made at many places in South Carolina, especially in the vicinity of Orangeburg and along Upper Three Runs. Lists of the species are included in the locality descriptions in this paper.

Between streams the $\mathrm{McBean}$ is generally covered by the Barnwell sand. The McBean probably does not extend under cover far southward beyond its area of outcrop. If it was originally deposited in the southern part of the State, it was probably eroded away before the sediments of Jackson age were deposited in that region.

Because of the lack of recognizable horizon markers, it is difficult to determine the dip of the McBean formation. No irregularities in structure have been detected, and the dip appears to be toward the south at the rate of about 10 or 15 feet to the mile.

"Cooke, C. W., and Shearer, H. K., op. cit., p. 50.

veatch, Otto, and Stephenson, L. W., op. cit., pp. 230-240. 
Ellenton (98).-Lumps of yellow sandy chert containing poorly preserved shells of mollusks are turned up by the plow on the hillside above Upper Three Runs, $1 \frac{1}{2}$ miles northwest of Ellenton. The rock is probably derived from the McBean formation. Fine yellow to gray sand containing silicified chertlike lumps crops out on the south side of the wagon bridge over Upper Three Runs, 1.6 miles from Ellenton, at an altitude 5 or 10 feet higher than the bridge. No fossils were seen here, but the rock is probably at about the same horizon as the fossiliferous chert in the field.

Tinker Creek.-Several exposures of the McBean formation are known along Tinker Creek, a tributary of Upper Three Runs rising in Barnwell County. The following section is taken from unpublished notes of T. W. Vaughan:

Section of McBean formation exposed on public road 200 feet east of Hixons Bridge, Tinker Creek, 121/2 miles west of Williston (99)

3. Red, white, and yellow sand.

Feet

2. Deep-red sand containing fossils, glauconite, and numerous splotches of lignitic matter. The whole bed was prob-

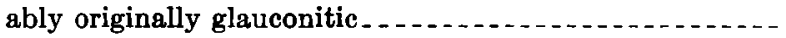

1. Pea-green shale, argillaceous and soft.

The following section is adapted from sections by Sloan ${ }^{81}$ and Vaughan: ${ }^{82}$

Section of McBean formation on south side of Tinker Creek, 0.2 mile east of Hixons Bridge and 900 feet north of the Hixon house

5. Deep-red firm sand

4. Clay seam

3. Fine yellow sand ............................. 6-18

2. Mottled pea-green and dark-drab massive clay shale with fossils along the upper surface........... 4

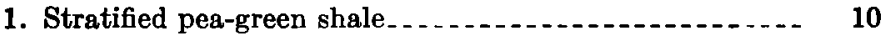

Marl beds of the McBean formation and of the Barnwell sand are exposed on the south side of Tinker Creek (100) about three-fourths of a mile below Coxs Bridge, which is about 2 miles above Hixons Bridge. The McBean formation consists of greenish-yellow argillaceous sand and shells. It is overlain by highly calcareous white marl containing patches of greenish sandy marl. Fragments of Ostrea georgiana that were found loose at this locality appear to have come from this upper bed, which is probably equivalent to the Ostrea georgiana zone at the base of the Barnwell formation in Georgia. The fossils listed below were collected from an old marl pit about 40 feet above the creek.

a Sloan, Earle, op. cit. (Catalogue), p. 268.

s Vaughan, T. W., un publishod field notes, November 26, 1907. 
7733. South side of Tinker Creek, Aiken County, about three-fourths of a mile below Coxs Bridge; C. Wythe Cooke, collector, May 2, 1916:

Volutocorbis petrosus (Conrad)?

Nucula sp.

Leda, 2 sp.

Ostrea divaricata Lea

Pecten sp.

Corbula alabamiensis Lea
Corbula extenuata Dall

Tellina papyria Conrad Cytherea discoidalis Conrad?

Venericardia "planicosta (Lamarck)"

Pteropsis lapidosa (Conrad)

Spisuls praetenuis (Conrad)?

The following section shows part of the McBean formation below the marl pit:

Section of McBean formation on south side of Tinker Creek, half to three-fourths of a mile below Coxs Bridge

2. Coarse reddish tough sand at base, becoming finer above and grading into partly indurated fine greenish-yellow

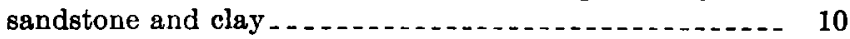

1. Fine incoherent yellow sand. To water level........ 4

Fed 4

The following section, adapted from Vaughan's field notes, ${ }^{83}$ must have been measured not far from the old marl pit. A section at the same locality ("Kennedy's Scarp") is given by Sloan. ${ }^{84}$

Section on south side of Tinker Creek, half a mile west of Coxs Bridge, 11 miles southwest of Williston

Barnwell sand (Eocene): $\quad$ Feet

6. Deep-red sand, etc......... 114

5. Compact chalky marl containing Ostrea georgiana and

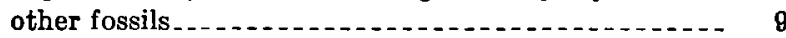

McBean formation (Eocene):

4. Brown granular, rather hard, compact glauconitic marl. Thickness indeterminate.

3. Dark-green, gray, or black laminated shale with small pebbles and coarse sand at the base. Thickness indeterminate. Aggregate thickness of beds 3 and 4

2. Dove-gray soft argillaceous shale, containing many

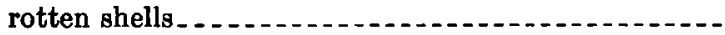

1. Green shale with rotten shells, grading toward base into hard brown glauconitic marl. A small collection of fossils was made from this stratum (Venericardia clavifer Gardner and Bowles) .......................

According to Vaughan, bed 1 of the preceding section is underlain at Coxs Bridge by greenish argillaceous sand, somewhat indurated, which contains numerous imprints of Venericardia "planicosta", Pteropsis lapidosa, and other fossils.

Seivern (101).--Very fine grained white or light-gray platy sandstone or shale is exposed about 65 feet (barometric measurement) above the water level in Three-cornered Pond, about 2 miles east of Seivern. According to Sloan, ${ }^{85}$ this sandstone is slightly fossiliferous

a Vaughan, T. W., unpublished field notes, November 26, 1907.

a Sloan, Earle, op. cit. (Catalogue), p. 207.

* Idem, p. 343. 
and is underlain by 16 feet of laminated Eocene shale that does not penetrate the ridge horizontally more than $\mathbf{4 0}$ feet from the outcrop. This deposit would seem to be a local patch similar to the basal Eocene near Fort Motte. It is provisionally correlated with the McBean formation, although Sloan may have been mistaken as to its Eocene age, and it may really belong to the Tuscaloosa formation.

Salley (102).-West of Salley, State highway 394 descends a hill about 100 feet high to Dean Swamp. Red sand, yellowish at the top, is exposed almost continuously from the village to the creek. Between 15 and 25 feet above the creek are lumps of disintegrating yellow and white chert, some of which contain obscure impressions of mollusks. The chert is overlain by fine and coarse sand and thinbedded yellow clay. Near the foot of the hill was found a fragment of an oyster, probably Ostrea johnsoni Aldrich, a species elsewhere characteristic of deposits of Lisbon age and reported by Sloan ${ }^{88}$ from this place. A few loose pebbles near the top of the hill may indicate a remnant of the Barnwell sand.

\section{LEXINGTON COUNTY}

Pelion-Woodford road.-On the road from Pelion to Woodford, 4.2 miles northwest of Woodford (103), medium to fine brick-red argillaceous sand resembling the McBean formation is overlain, with apparent unconformity, by a gravel bed composed of many lumps of red ferruginous sandstone and a few quartz pebbles in a matrix of tough red sand. This bed, which may be the base of the Barnwell sand, passes upward into medium-coarse red argillaceous sand.

On the same road 2.1 miles from Woodford (104) the section is as follows:

Section of McBean formation 2.1 miles northwest of Woodford

2. Coarse hard red argillaceous sand, the uppec part mottled yellow and gray. To top of hill

1. Fine laminated sand, white, yellow, or red, the color varying with the content of iron, with laminae of white and purple clay ....... 10

Gaston.- The high sandy plateau upon which Gaston is built forms the divide between the headwaters of First Creek, which flows northward into Congaree Creek, and Sandy Run, which flows southeastward into the Congaree River. Other small streams also radiate from Gaston. Sloan's $\dagger$ Congaree shale crops out near the heads of several of these streams beneath a thick cover of sand.

The type locality of the †Congaree shale appears to be on Elmore Williams' place at the head of First Creek, 0.8 mile west of Gaston (105). Sloan ${ }^{87}$ reports an 8-foot ledge of fuller's earth containing

* Sloan, Earle, op. clt. (Catalogue), p. 344.

is Idem, p. 346.

$143491-36-5$ 
numerous large casts of Venericardia "planicosta" and shark teeth, overlain by fossiliferous quartzite, exposed on the south side of a large natural amphitheater. The fuller's earth is provisionally assigned to the McBean formation.

The following section on the J. F. Mack property, 2 miles south of Gaston and 0.3 mile east of the Seaboard Air Line Railway (106), is adapted from Sloan. ${ }^{88}$

\section{Section of McBean formation 2 miles south of Gaston}

4. Sands inclosing an interrupted ledge of buhrstone that contains Ostrea johnsoni, and Scutella sp., $3 \frac{1}{2}$ inches in diameter. . . . 4.6

3. Argillaceous yellow sands interstratified with horizontal lines of white and purple clays

2. Plastic purple clay 3

1. Drab fuller's earth enclosing molds and casts (principally Venericardia "planicosta"). (†Congaree phase of Sloan.) Penetrated 4 feet by well.

Fossiliferous fuller's earth of the †Congaree shale crops out, according to Sloan, ${ }^{89}$ on the Sturkie (Zid) place, 3 miles southeast of Gaston, on the west side of Sandy Run, where it is overlain by sand and clay, and on the Wolf property, 1.8 miles southwest of Congaree Bluff and 4 miles northeast of Gaston.

\section{BAMBERG COUITT}

Edisto River.-According to Sloan ${ }^{00}$ pea-green marl is exposed at intervals along the right bank of the South Edisto River from a point near Holmans Bridge to a point 3 miles below Benneckers Bridge, a distance of about 8 miles. The following section was measured by the writer in 1917:

Section at Benneckers Bridge, 5 miles northeast of Denmark (107)

Barnwell sand(Eocene) or Brandywine formation (Pleistocene):

6. Yellow sandy soil, apparently residual from bed 5_._ 5

5. Coarse sand, orange at bottom but grading into brilliant brick red at top, somewhat mottled with greenish-gray splotches that resemble inclusions; well-rounded quartz pebbles averaging $3 / 4$ inch in diameter distributed throughout the bed but abundant only near the base; rather abrupt transition to underlying bed but no obvious break. . . . . 20

McBean formation (Eocene):

4. Medium-fine orange sand........... 11

3. Greenish-yellow laminated clayey sand ............ 16

2. Compact blue-green, very fine sandy marl, creamcolored when dry; spring issues at top.......... $11 / 2$

1. Concealed to water level_................ $11 / 2$

n Slosn, Earle, op. cit. (Catalogue), p. 347.

Idem, p. 348.

Idem, p. 275. 
When slightly oxidized, the marl (bed 2) is yellowish gray. It contains ostracodes and (probably) small foraminifers. It resembles the Cooper marl but appears to be McBean.

\section{ORANGEBURG COUNTY}

Willow Swamp (108).-There is a small showing of sandy marlstone and larger ledges of similar silicified rock at the mouth of Willow Swamp, 3 miles south-southwest of Norway. The rock seems to be the same as softer marl at Benneckers Bridge, 5 miles away. One lump containing indeterminable fragments of pelecypods was found.

Rocky Swamp (109).-The bluff east of Rocky Swamp on the road from Springfield to Norway 4 miles east of Springfield contains a 6-foot zone of discontinuous ledges of sandy chert embedded in compact red argillaceous sand that appears to be derived, in part, from the disintegration of chert. The top of the chert zone is about 25 feet above water level in the creek. The chert contains many fossils, among them Venericardia claiboplata Gardner and Bowles. There are lumps of similar rock in the bed of the creek 2 miles downstream. This place is the site of Stroman's mill, described by Tuomey, ${ }^{91}$ who mentions also a thick bed of white silicified shells at the mouth of Rocky Swamp.

Phillip's mill (110).-At Phillip's mill, on West Goodland Creek, 1.6 miles northeast of Springfield, fine laminated greenish sand weathering red extends from water level to a height of about 15 feet above the dam. It is overlain by massive fine red sand that with the underlying bed is referred to the McBean formation. Coarse red sand crops out on the hillsides above the mill. A few fossil shells, including a Turritella and a Corbula, have been found in the McBean formation at this place.

Bull. Swamp road.-The following section was measured on the Bull Swamp road 13/2 miles southeast of Etheridge Mill and 13 miles northwest of Orangeburg:

Section 11/2 miles southeast of Etheridge Mill (111)

Brandywine (?) formation (Pleistocene?):

3. Massive brick-red sand with a few white beds near the top and black ferruginous sandstone crusts in the

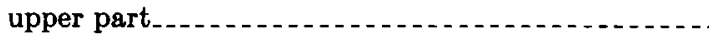

Unconformity.

McBean formation (Eocene):

2. Fine greenish-yellow sand containing small grains of glauconite and lumps of soft, yellowish clay that hardens into chertlike masses; thickness about......... 2

1. Fine greenish-yellow argillaceous sand; to foot of hill. 10

91 Tuomey, Michael, op. cit., p. 151. 
Bed 2 appears to represent the same horizon as the fossiliferous sand south of Early Branch, on Limestone Creek, and at other places.

A section in which the beds are very irregular is exposed on the east side of Limestone Creek on the Bull Swamp road 7 miles northwest of Orangeburg.

Section at Limestone Creek (112)

Brandywine (?) formation (Pleistocene?):

Feet

4. Coarse red conglomeratic sand, somewhat finer near the top, mottled red and white on exposed surfaces; to top of hill........

Probable unconformity.

McBean formation (Eocene):

3. Massive red sand containing streaks of flat clay pellets_

2. Red, purple, or greenish laminated sand and clay,

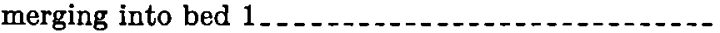

1. Greenish-yellow very fine sand, partly silicified and containing casts of mollusks; Venericardia claiboplata Gardner and Bowles loose at base; weathers into bright-red laminated or massive sand with lenses and stringers of chert

The lower bed in the preceding section appears to represent the light porous sandstone south of Early Branch.

Big Beaver Creek (113).--The following section was observed on the south side of Big Beaver Creek at a mill pond on the Salley road, 1.5 miles northeast of the crossing of the Ninety-six road and 4.5 miles southwest of the town of North:

\section{Section of McBean formation on Big Beaver Creek}

2. Medium-coarse red argillaceous sand with an irregular

1. Fine orange sand passing downward into greenish-yellow laminated flaky sandy clay; shells 17 feet above the pond; base concealed; to water level in pond.......

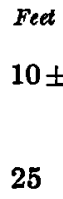

25

New Bridge (114).-Poorly preserved fossil shells are turned up by the plow in fields west of the road south of the North Edisto River at New Bridge, 2 miles south of North. They are doubtless derived from the McBean formation.

Poplar Spring (115).-A lump of fossiliferous chert found many years ago by Frank Burns at Poplar Spring, about 5 miles west of Orangeburg, probably indicates the presence of the McBean formation there.

Caw Caw Swamp (116).-Large collections of fossils have been obtained from the McBean formation on the Bull Swamp road east of Caw Caw Swamp, 21/2 miles northwest of Orangeburg. The section and list follows: 


\section{Section at Caw Caw Swamp}

Brandywine(?) formation (Pleistocene?):

3. Massive red sand with lighter-colored clayey sand in the middle; to top of hill.

Probable unconformity.

McBean formation (Eocene):

2. Fine bright-red (originally green) sand containing pockets of shells at bottom; lower 4 feet massive; upper part with thin laminae of green clay ....... 10

1. Green clay with pockets of shells.......... 2

2009. Caw Caw Swamp, 21/2 miles west of Orangeburg; Frank Burns, collector; identified by $T$. W. Vaughan:

\section{Acteon idoneus Conrad}

Bullínella galba Conrad

Terebra houstonia Harris

Conus sauridens Conrad

Pleurotoma prosseri Harris

Pleurotoma lerchi Vaughan

Pleurotoma nupera Conrad

Pleurotoma desnoyersii Lea

Pleurotoma moorei Gabb

Pleurotoma nodocarinata Gabb

Pleurotoma sp.

Cancellaria sp.

Oliva sp.

Ancilla staminea Conrad

Ancilla ancillops Heilprin

Volutocorbis petrosus (Conrad)

Caricella pyruloides Conrad

Turricula polita (Gabb)

Conomitra sp.

Fusinus magnocostatus Conrad

Lirofusus thoracicus (Conrad)

Terebrifusus amoenus (Conrad)

Ficus (Fusoficula) texana (Harris)

Pseudoliva vetusta (Conrad)

\author{
Laevibuccinum prorsum (Conrad) \\ Phos sagenus (Conrad) \\ Murex engonata Conrad \\ Cypraea kennedyi Harris \\ Turritella carinata var. praecarinata \\ Harris \\ Turritella nasuta var. houstonia Harris \\ Tuba antiquata Conrad \\ Calyptraea trochiformis (Lamarck) \\ Crepidula lirata Conrad \\ Lunatia eminula Conrad \\ Natica semilunata Lea \\ Nucula ovula Lea \\ Leda semen Lea \\ Leda media Lea \\ Yoldia claibornensis (Conrad) \\ Trigonarca decisa (Conrad) \\ Glycymeris idoneus (Conrad) \\ Venericardia claiboplata Gardner and \\ Bowles its \\ Cytherea perovata Conrad \\ Chama sp. \\ Amphidesma sp.
}

Early Branch (117).-An instructive section of the McBean formation is exposed on the Columbia road south of Early Branch, 51/2 miles north of Orangeburg. This resembles the section at the locality called by Sloan ${ }^{22}$ "Pooser's Hill" but stated by him to be on the Bull Swamp road south of Turkey Creek, which crosses the Columbia road $1 \frac{3 / 4}{4}$ miles south of Early Branch.

At the base of the section is about 16 feet of very fine gray to white porous, friable sandstone of very light weight. It appears to be a sandy marl from which all the lime has been leached. The lower part of this bed contains a little clay and is softer than the upper part. This porous sandstone contains the impressions of many species of fossil shells, some of which are listed below.

01* Identifled by Julia Gardner.

a Sloan, Earle, op. cit. (Catalogue), p. 276. 
Above the porous sandstone and connected with it by transition beds, is a bed of pale-green clay and sand that weathers brick-red and contains in the middle part pockets of sand loaded with silicified shells. This bed extends to the top of the hill, a thickness of about 25 feet.

Farther south on the road and slightly higher, are patches of fossiliferous sand in red clay overlain by pebbly red clay.

The fossils collected at Early Branch are listed below:

7722. Columbia road south of Early Branch, 51/2 miles north of Orangeburg; casts in porous sandstone at base of section; C. Wythe Cooke, collector, 1916:

Cancellaria sp.

Turricula polita (Gabb)?

Turritella dutexata Harris?

Turritella, several species

Phos sp.

Crepidula dumosa Conrad?

Leda sp.

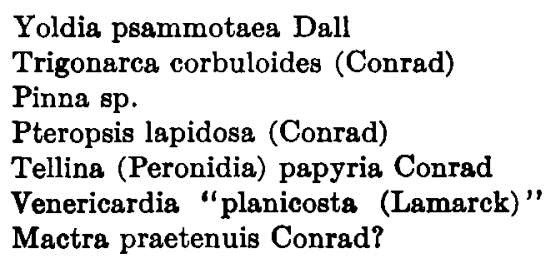

To this list should be added Modiolus sp. and Corbula alabamiensis Lea, collected by Vaughan at this same locality (no. 4579).

From collections made from the red sand above the porous sandstone the following species have been identified:

5580. Pooser's Hill, 5.1 miles north of Orangeburg; T. Wayland Vaughan' collector, 1907:

\section{Acteon elegans Lea \\ Acteon sp.}

Terebra texagyra Harris

Conus sauridens Conrad

Pleurotoma nodocarinata Gabb

Pleurotoma nupera Conrad

Pleurotoma childreni Lea

Pleurotoma lesueuri Lea

Pleurotoma moorei Gabb

Amblyacrum tabulatum (Conrad)

Amblyacrum stantoni Vaughan

Amblyacrum sp.

Peratotoma insignifica (Heilprin)

Drillia sp.

Cochlespira bella (Conrad)

Borsonia sp.

Cancellaria, 3 sp.

Ancillaria scamba (Conrad)

Volutocorbis petrosus (Conrad)

Turricula polita (Gabb)

Fusinus irrasus Conrad

Lirofusus thoracicus (Conrad)

Ficus (Fusoficula) aff. F. texana (Harris)

Pseudoliva vetusta (Conrad)

Phos sagenus (Conrad)

Laevibuccinum prorsum Conrad

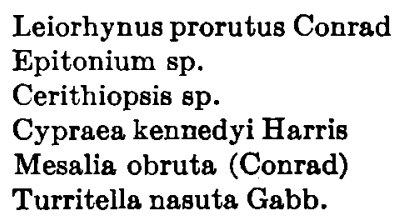

Leiorhynus prorutus Conrad

Epitonium sp.

Cerithiopsis sp.

Cypraea kennedyi Harris

Mesalia obruta (Conrad)

Turritella nasuta Gabb.

Turritella nasuta Gabb var.; also at Hicksons Bridge

Turritella dutexata Harris

Turritella, 2 sp.

Sinum declive (Conrad)

Crepidula lirata Conrad

Natica semilunata Lea

Dentalium minutistriatum Gabb

Nucula, 3 sp.

Leda pharcida Dall

Leda media Lea

Leda sp.

Arca rhomboidella Lea

Venericardia claiboplata Gardner and

Bowles.

Cytherea discoidalis Conrad

Cytherea perovata Conrad

Petricola sp.

Corbula alabamiensis Lea

Corbula extenuata Dall 
A collection of fossils made by Burns at this locality (station 2012) and identified by T. W. Vaughan includes Cornulina armigera Conrad, Natica aetites Conrad, and Nucula magnifica Conrad.

The fossiliferous sand and clay at Early Branch are probably of nearly the same age as the sand on McBean Creek, Ga., that carries the same species of shells. The porous sandstone containing Pteropsis lapidosa appears to be equivalent to the marl at McBean.

According to Sloan, the sandstone at "Pooser's Hill" merges laterally into low-grade calcareous marl that was formerly quarried for agricultural purposes at "Wannamaker's lime hole", 0.3 mile to the southwest.

Little Limestone Creek (118).-The following section is exposed along the road east of Little Limestone Creek, half a mile south of the Calhoun County line and 1.7 miles west of the Kennerly road.

Section of McBean formation, east of Litlle Limestone Creek

3. Fine green and red sand with chert in the upper 3 feet..... 8

2. Hard irregular lumps of yellow chert mixed with green and red sand. . . .

1. Fine light-green and brick-red sand .

Orangeburg.-From a thin sand bed discovered by Burns in an old brickyard at Orangeburg the following species were collected.

2021. Old brickyard, Orangeburg; Frank Burns, collector, 1886; identified by T. W. Vaughan:

Conus sauridens Conrad

Pleurotoma nodocarinata Gabb

Pleurotoma childreni Lea

Pleurotoma texanopsis Harris

Pleurotoma, $2 \mathrm{sp.}$

Amblyacrum stantoni Vaughan

Ancilla staminea Conrad

Lirofusus thoracicus (Conrad)

Ficus (Fusoficula) texana (Gabb)
Phos sagenus (Conrad)

Calyptraea trochiformis Lamarck

Turritella nasuta houstonia Harris

Nucula magnifica Conrad

Leda semen Lea

Trigonarca, $2 \mathrm{sp.}$

Arca rhomboidella Lea

Crassatellites protexta (Conrad)

Venericardia "planicosta (Lamarck)"

Specimens eridently representing the stratigraphic equivalent of the lower bed (porous sandstone) at Early Branch and containing the characteristic species Pteropsis lapidosa were found by T. W. Vaughan on the dump at the mouth of the northern effluent of the Orangeburg sewerage system, on the bank of the Edisto River.

The following section was measured in 1917 in excavations on the bank of the Edisto River at the municipal waterworks at Orangeburg. 
Pleistocene (?):

Feet

3. Coarse red argillaceous sand with pebbles at the

bottom; to top of hill back of power plant, about.... 30 Unconformity.

McBean formation (Eocene):

2. Fine white sand with a greenish tinge; weathers red and contains flakes of silicified material . ............... 11

1. Light-green sandy clay; to water level in Edisto River.- $\mathbf{1 5}$

\section{CALHOUN COUNTY}

Caw Caw Swamp.-The following section shows the character of the McBean formation in the southwestern part of Calhoun County. The section is exposed 0.2 mile west of Caw Caw Swamp on a road connecting the Kennerly road with the Orangeburg-Columbia road, just above the Orangeburg County line.

Section of McBean formation, O.2 mile west of Caw Caw Swamp (120)

Feet

3. Orange and red sand, rather coarse . .

2. Coarse greenish-gray glauconitic marl at base, passing into yellowish-gray clay at top. .

1. Hard red argillaceous sand, mottled with gray; to floodplain of Caw Caw Swamp.............. 10

A section on the northwest side of Caw Caw Swamp, 10 miles north of Orangeburg, is as follows:

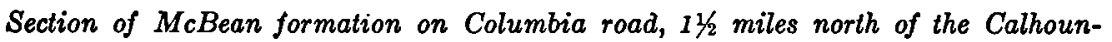
Orangeburg County line (121)

$\begin{array}{lr}\text { 5. Massive red sand; to top of hill, about } & \text { Feet } \\ \text { 4. Brittle yellow chert } & 20 \\ \text { 3. Fine greenish-yellow sand } & 6 \\ \text { 2. Dark-green sandy, glauconitic marl } & 6 \\ \text { 1. Yellow sand, about_ }\end{array}$

Senn farm (122).-Lumps of fossiliferous sandstone and loose silicified shells are turned up by the plow on the farm of Eugene Senn, north of the Kennerly road and very near the Calhoun-Lexington County line, 7 miles east of Swansea. Large shells of Venericardia claiboplata Gardner and Bowles are abundant, and many other species are present. These shells lie near the top of the hill and about 50 feet above the waterfalls produced by ledges of fuller's earth in the branches of Beaver Creek.

Gully 6 miles northwest of St. Matthews (123).-Yellow chert embedded in orange sand comes to the surface in a gully back of a schoolhouse 6 miles northwest of St. Matthews. No fossils were found here, but the chert probably occupies approximately the same stratigraphic position as the fossiliferous sandstone on the Senn farm. 
Waterfalls produced by ledges of fuller's earth are found in the ravines nearby and 90 feet lower (barometric reading).

High Hill Creek.-Sections showing the composition of the McBean formation and its relation to the Black Mingo formation near Calvary Church and Bates Mill, on High Hill Creek, are recorded on pages 53 and 54. The McBean formation at these exposures consists chiefly of red sand and greenish laminated clay.

Gully 3.9 miles north of St. Matthews (124).-A greater thickness of the McBean formation is exposed in a gully heading at the road from St. Matthews to Calvary Church, 3.3 miles north of St. Matthews and 1.5 miles south of Calvary Church. The gully is tributary to High Hill Creek.

\section{Section of McBean formation in gully 3.3 miles north of St. Matthews}

6. Fine greenish-red argillaceous sand; to level of road at head of gully .......................................

5. Soft white siliceous material, probably silicified marl; both upper and lower surfaces irregular ............

4. Fine greenish-brown glauconitic sand containing white silicified particles, probably broken shells ..............

3. Incoherent sand, coarse and pebbly at base, finer above; color ranges from yellowish white to bright red..........

2. Lenticular masses of greenish-yellow clay and gray sandstone, passing into flaky greenish clay at top. . _...... 0-10

1. Coarse pebbly incoherent sand with plentiful seeps of water, giving rise to a strong stream; thickness seen . . ...-

Bed 1 of this section is probably very near the bottom of the McBean formation.

Head of Lyons Creek (125).-A cut on United States Highway 21, 11/2 miles south of St. Matthews, at the head of Lyons Creek, shows about 45 feet of little-weathered material, all of which appears to be referable to the McBean formation. The lower part is very fine yellow, iron-stained, sparingly glauconitic and micaceous sand containing many casts of marine mollusks, chiefly gastropods. Higher in the section the fine sand contains many angular coarser grains. Marine pelecypods were found in material of this kind about 25 feet below the top. Still higher the sand becomes generally coarser and is embedded in clay, but there are patches of fine sand within 10 feet of the top of the hill. The upper 5 or 10 feet of the sand includes many partly rounded and corroded pebbles 2 inches in diameter. The general color of the exposure is reddish yellow or buff.

Lyons Creek.--The McBean formation is exposed on Lyons Creek where it is crossed by the Moncks Corner road and by the Belleville road. At the Moncks Corner crossing (126), which is 4.4 miles southeast of St. Matthews and 5.4 miles northwest of Creston, the formation consists chiefly of glauconitic sand; on the Belleville road 
(from Orangeburg to Fort Motte), 41/2 miles northwest of Creston, the section is as follows:

Section on Belleville Road at Lyons Creek (127)

McBean formation (Eocene) :

4. Light-green fine, laminated glauconitic sand weather-

Fect

ing rich red brown and bright brick red; upper part encloses patches of pebbles; shell fragments found 20 feet below the top; thickness about..............

3. Coarse ferruginous sand (basal conglomerate) with coarse pebbles in the lower part; cross-bedded in places; contains inclusions of silicified clay that appear to be derived from the underlying bed;

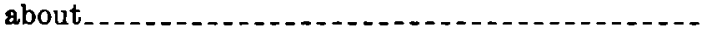

Unconformity.

Black Mingo (?) formation (Eocene):

2. Gray plastic clay containing laminae of micaceous sand; the upper part contains a mass of hard, brittle, chertlike silicified clay ................ 8

1. Concealed to water level in Lyons Creek . . .

Somewhere in this vicinity the following fossils were collected in the McBean formation:

4589. Keitt's Ravine, $4 \frac{1}{2}$ miles northwest of Creston; T. Wayland Vaughan, collector, 1907:

Fusinus limulus Conrad

Mesalia claibornensis Harris

Turritella aff. T. carinata Lea

Natica semilunata Lea

Nucula spheniopsis Conrad

Nucula magnifica Conrad

Leda aequalis Conrad

Yoldia, large species

Limopsis aff. L. aviculoides (Conrad)

Venericardia "planicosta (Lamarck)"
Venericardia sp.
Cytherea ovata Rogers, var.
Tellina, 3 sp., one near T. ovalis Lea
Semele, 2 sp.
Spisula praetenuis Conrad
Spisula sp.
Corbula fossata Meyer and Aldrich
Corbula alabamiensis Lea

Moncks Corner road (128).-The following section was measured on a small branch tributary to Halfway Swamp on the Moncks Corner road 3.3 miles northwest of Creston:

\section{Section 9.9 miles northwest of Creston}

Pleistocene (?):

Feet

5. Tough gray sandy clay, like bed 4 but with a discontinuous zone of coarse gravel and 4-inch cobbles at base. Passes upward into brilliant brick-red argillaceous sand containing a few pebbles. There is no visible break between beds 4 and 5 . To top

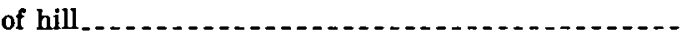

4. Tough gray sandy clay with cherty lumps at base.... 
Section 3.8 miles northwest of Creston-Continued

Eocene (McBean formation):

3. Highly glauconitic green sand, coarser than bed 2. The upper part of bed 2 contains patches of similar material.

2. Fine pale-green glauconitic sand with clay laminae; weathers brick reci

1. Concealed to water level in branch

Lang Syne (129).-The interesting exposures on the Lang Syne plantation, about $1 \frac{1 \%}{2}$ miles east of Fort Motte, have been known to geologists for many years. Ruffin ${ }^{93}$ noted fossils there in 1843 , and Tuomey ${ }^{94}$ in 1848 described the section that Dall, ${ }^{95} 50$ years later, selected as the type of his †Orangeburg formation. Sloan, ${ }^{96}$ in 1908, published a section at Lang Syne, and the field notes of Vaughan and Stephenson include sections from the same locality.

The Tuscaloosa formation is cut into by several ravines in the vicinity of Lang Syne and Fort Motte, and resting in hollows of its very irregularly eroded surface are patches of lower Eocene sand and fuller's earth, above which is red and green sand of the McBean formation. The following section was measured at the upper end of Tomb Field Gully, a ravine heading near the old private cemetery.

\section{Section of McBean formation in Tomb Field Gully}

4. Massive greenish-yellow medium-grained glauconitic sand, weathering brilliant brick red; contact with underlying bed sharply defined; to top _..............

3. Fine yellowish argillaceous and micaceous sand with rhomboidal fracture..............................

2. Fine incoherent yellow sand containing fragments of Ostrea divaricata, irregular indurated lumps and laminae of yellow clay, and carbonaceous partings . . . . . ........ 4-6

1. Coarse yellow sand and thin beds of plastic greenish clay, passing into coarse conglomeratic gravel with pellets of kaolin and quartz pebbles as much as 1 inch in diameter at base; thickness probably about

About 100 yards below the head of the gully beds 2 and 3 of the preceding section are hardened into brittle fine-grained sandstone, large blocks of which cover the talus slopes. Bed 1 appears to be the basal member of the McBean formation, and the Tuscaloosa formation is doubtless not far below.

13 Ruffin, Edmund, Report of the agricultural survey of South Carolina, p. 47, 1843.

4 Tuomey, Michael, Geology of South Carolina, p. 149, 1848.

2u Dall, W. H., A table of North American Tertiary horizons: U. 8. Geol. Survey I8th Ann. Rept., pt. 2, p. $344,1898$.

N Sloan, Earle, op. cit. (Catalogue), p. 354. 
The †Lang Syne beds of Sloan, ${ }^{97}$ here placed in the Black Mingo formation, are exposed at a low waterfall at the mouth of Tomb Field Gully and in the bed of the stream below the fall. The strata consist of fine-grained black carbonaceous sand with a ledge indurated by limonite forming the waterfall at the hydraulic ram. Below the ram gray to black sandy clay, carbonaceous in places and merging laterally into loose black carbonaceous sand, is exposed in the bed of the stream. According to Sloan the TCongaree shales intervene between the fLang Syne beds and the †Warley Hill series (McBean formation) and are separated from the $+W a r l e y$ Hill by an unconformity, but at the time of my visit (Apr. 27, 1916) the beds referred to the †Congaree shales by Sloan were either covered or not recognized.

The †Lang Syne beds and the †Congaree shales are absent in another gully on the Lang Syne plantation about half a mile west of Tomb Field Gully, in which the McBean formation rests directly upon the Tuscaloosa formation.

Section in gully half a mile west of Tomb Field Gully

McBean formation (Eocene):

Feet

4. Massive red argillaceous glauconitic sand containing pebbles near the top.

3. Greenish-yellow laminated semiplastic elay with partings of sand...................................

2. Incoherent yellow sand and thin beds of yellow clay with a conglomeratic layer at base..............

Marked unconformity.

Tuscaloosa formation (Upper Cretaceous):

1. White plastic clay.

The Upper Cretaceous-Eocene contact at this place is approximately 50 feet higher than the exposure of the fLang Syne beds in Tomb Field Gully.

Road 5 miles southeast of Fort Motte (130).-About 4 miles northwest of Lonestar a side road branches off to the north from the Fort Motte road, and 1 mile beyond the fork crosses a small stream. The following section was measured along the road south of the stream:

\section{Section $1 \frac{1}{2}$ miles northwest of Warley Hill}

McBean formation (Eocene):

4. Ferruginous shale, passing into fine reddish sand; poorly exposed; thickness about. .................... 15

3. Fine yellow sand, probably slightly calcareous $\ldots \ldots \ldots . . .6$

2. Yellow limonitic clay, color apparently derived from weathered glauconite.

Black Mingo formation (Eocene):

1. Light-gray micaceous fuller's earth, brown when wet; contains comminuted plant remains.............

"r Sloan, Earle, op. cit. (Catalogue), p. 355. 
Warley Hill (131).-The hillside south of Stouts (Stoudenmire) Creek on the road from Fort Motte to Lonestar, 7 miles southeast of Fort Motte, was chosen by Sloan ${ }^{98}$ as the type locality of his $\dagger$ Warley Hill phase. This locality was examined by Lyell on his first visit to the United States in 1841-42, and it was also known to Tuomey.

\section{Section of McBean formation at Warley Hill}

10. Yellow sandy clay at base, passing into reddish-yellow massive argillaceous sand containing many small grains of glauconite............. 16

9. Fine green to yellow glauconitic sand enclosing Venericardia sp. and other fossils................... 6

8. Greenish and yellow to gray brittle, nonplastic clay resembling fuller's earth; a few casts of mollusks......... 14

7. Sparingly glauconitic light-weight gray to yellow marl; a few casts of mollusks............................ $21 / 4$

6. Greenish-gray glauconitic sand with some clay at top.... 1

5. Flaky brown nonplastic clay _._.

4. Slightly coherent fine yellow or red sand $\ldots \ldots \ldots \ldots \ldots 2$

3. Compact brittle blue-gray shale or clay (fuller's earth); lower part with slaty cleavage, upper part more massive and with conchoidal or hackly fracture . . . . . . _. 8

2. Fine gray to yellow sand mingled with black carbonaceous sandy clay; a 6 -inch indurated ledge at top...... 21/2

1. Concealed to level of Stouts Creek............. 14

The topmost bed of this section was doubtfully referred by Sloan to the Barnwell sand; beds 8 and 9 are nearly equivalent to his †Upper Warley Hill marl and tLower Warley Hill shales; beds 2 to 7 were correlated with the fCongaree shale; and the concealed interval at the bottom includes the fUpper Black Mingo (?) of Sloan. The entire section is here tentatively placed in the McBean formation.

Sandy Run (132).-The following section is exposed on a long hill on the old State Road (probably now United States Highway 21 ), 1.1 miles southeast of Sandy Run:

\section{Section on State Road 1.1 miles southeast of Sandy Run}

MeBean formation (Eocene): Feet

5. Light-gray fuller's earth

4. Fine red sand, about........... 6

3. Laminated gray sandy clay, weathering red........ 1

2. Coarse red pebbly argillaceous sand, about.......... 3

Unconformity.

Tuscaloosa formation (Upper Cretaceous):

1. Coarse white arkosic sand.

is Slosn, Earle, op. cit. (Catalogue), pp. 300-301, 457. 
Beaver Creek (133).-Brittle clay forms waterfalls in the branches at the head of Beaver Creek. The following section on the land of B. D. Livingston may be regarded as typical:

\section{Section of Eocene (McBean? formation) at falls of Beaver Creek}

$\begin{array}{lr}\text { 2. Gray to black carbonaceous sand enclosing shark teeth.-_- } & 6 \\ \text { 1. Dark-gray somewhat sandy and micaceous clay, breaking } & 6 \\ \text { with conchoidal fracture._. } & 6\end{array}$

On the hillsides about 50 feet above the measured section lumps of fossiliferous sandstone and loose shells are found in considerable abundance. A large variety of Venericardia "planicosta" is the most conspicuous fossil, but other species that are diagnostic of the $\mathrm{McBean}$ formation are present.

\section{DEPOSITS OF JACKSON AGE GENERAL CHARACTER}

The Jackson formation, typically developed at Jackson, Miss., is the youngest part of the Eocene. Its representatives in South Carolina are the Santee limestone, the Cooper marl, and the Barnwell sand. They underlie a large part of the Coastal Plain west of the Congaree and Santee Rivers.

The Santee limestone consists chiefly of alternating hard and soft layers of more or less glauconitic impure limestone or marlstone; the Cooper is brownish marl, generally very massive and homogeneous; the Barnwell is for the most part sand but includes a limestone member at the bottom.

The Santee underlies the Cooper marl and appears to be equivalent to the basal part of the Barnwell. The Cooper marl may be of the same age as the upper part of the Barnwell, but no direct evidence as to their relations has been detected.

The faunas of the three formations also differ. The Santee contains a profusion of Bryozoa and several widely ranging species of shallowwater mollusks that indicate its correlation with the Castle Hayne marl of North Carolina, with the Moodys marl member of the Jackson formation of Mississippi, and with the Periarchus-bearing bed (socalled "Scutella bed") at the base of the Jackson formation of southwestern Alabama. The Cooper marl contains many Foraminifera that appear to indicate that the formation is of Jackson age and several peculiar species of mollusks whose closest affinities are also found in the Jackson. Fossils are not abundant in the Barnwell, but the calcareous lower part of the formation contains Lepidocyclina ocalana and other fossils by which it is correlated with the lower part (Tivola tongue) of the Ocala limestone in Georgia. The correlation of the formations of Jackson age in other States is shown in the table on page 40 . 
The mapping of the formations of Jackson age in South Carolina is especially difficult because the formations are at many places covered by a variable thickness of younger deposits. Exposures of the Barnwell sand are much more numerous than those of the calcareous formations of Jackson age, but the sand closely resembles Pliocene or Pleistocene terrace deposits. The boundaries shown on plate 2 are only approximate.

The softness and ready solubility of the Santee limestone and Cooper marl doubtless facilitated the degradation of their exposed surfaces during Oligocene time to a level, nearly featureless plain that offered no barrier to the rising tides of the Miocene and Pleistocene. The present surface features of the area underlain by the Cooper marl and the Santee limestone are those of a series of low terraced plains, modified, where the sandy cover is not too thick, by sinks or ponds and considerably dissected along the upper courses of the principal streams and their tributaries.

These formations of Jackson age occupy roughly a quadrant of a shallow basin whose center lies in the Atlantic Ocean somewhere off the mouth of the Savannah River. The rates of dip along the radii are difficult to ascertain, for recognizable horizon markers within the formations are very few, the altitude of the base is known in few places, and the present surface is an eroded plain that bevels the gently tilted beds. It is not likely that the dip anywhere exceeds 15 feet to the mile except possibly in the northern part of Berkeley County.

\section{HISTORY OF THE NAMES "SANTEE" AND "COOPER"}

The calcareous composition of the "white limestone" of South Carolina, which was unlike any known Eocene deposits of this country but resembled more the $\dagger$ Secondary strata (Mesozoic), led the early geologists, among whom may be mentioned Vanuxem, Morton, and Conrad, to class the marls and limestones of the low country with the Upper Cretaceous. Charles Lyell, during his first visit to the United States (January 1842), examined these rocks and pronounced them Eocene.99 He associated the name "Santee" with the formation, but it is evident from the context that he had no intention of proposing it as a permanent formation name. He says: ${ }^{1}$

On reviewing the fossil Invertebrata which I collected from various localities in the Santee white limestone of South Carolina, I find many which will at once be recognized as species known to belong to the Eocene formation of Claiborne and other places.

Among the localities visited by Lyell may be mentioned The Grove, on the Cooper River, Santee Canal, Cave Hall, and Eutaw Springs.

" Lyell, Charles, Observations on the White limestone and other Eocene or older Tertiary formations of Virginia, South Carolina, and Georgia: Geol. Soc. London Quart. Jour., vol. 1, pp. 429-442, 1845; Travels in North America in the years 1941-42, vol. 1, pp. 138-142, New York, Wiley \& Putnam, 1845.

1 Lyell, Charles, op. cit. (Quart. Jour.), p. 434. 
Lyell's belief that the Santee limestone is Eocene was communicated orally to Edmund Ruffin, but Ruffin appears not to have been thoroughly convinced of its correctness, for he says: ${ }^{2}$

The still remaining uncertainty as to the age of this great deposit will serve as my excuse for adopting for it a provisional name that is merely and truly descriptive and affirms nothing that may be hereafter necessary to retract. The "Great Carolinian bed" of marl will serve every present purpose of designation and distinction as well as if it were definitely settled and the bed named either "Upper Cretaceous" or "Eocene."

Ruffin gives an excellent description of the physical properties and areal distribution of the †Great Carolinian bed under the heading "General character, position, and extent of the Great Carolinian bed of marl", with the subheadings "Marl of Ashley and Cooper Rivers and their branches", "Marls of the Santee River and its branches", "Marls of the Edisto River and its branches", "Marl of Little Salkehatchie and its branches", and "Marl of Savannah River and its branches in Barnwell". Except that he included in his description certain marls that are now referred to the McBean formation, his tGreat Carolinian bed, with little modification, conforms to the present conception of the Santee limestone and the Cooper marl. The essential continuity of the formations is stated by him as follows: ${ }^{3}$

These lines of exposures offered by nature in the numerous and extensive swamps and also of marl easily accessible for use will serve to exhibit the actual connection of the marl of the Ashley and Cooper and the Santee. And also, if this mode of examination were pursued, it is likely that the calcareous bed would be in like manner found not only to be connected but also accessible from the Ashley to the Stono River and perhaps to the Edisto.

In 1848 Tuomey ${ }^{4}$ pointed out differences between the Santee beds and the marl beds of the Ashley and Cooper Rivers and their tributaries, which he considered stratigraphically higher. He repeatedly makes use of the terms "Santee beds" and " Ashley beds" as formation names, but uses the name "Cooper" only in association with †"Ashley."

Clark ${ }^{5}$ followed Tuomey in referring both the Santee "beds" and the tAshley and Cooper beds to the Eocene, and Dall ${ }^{6}$ definitely correlated the Santee beds with the $\dagger Z$ euglodon beds of his Jacksonian "stage" but referred the †Cooper River marls to his "lower Oligocene or Vicksburgian stage" and applied the name t"Ashley River marl" to the Miocene phosphate deposits.

\footnotetext{
I Ruffin, Edmund, Report of the commencement and progress of the agricultural survey of South Carolina for 1843, p. $7,1843$.

I Idem, p. 11.

- Tuomey, Micheel, Report on the geology of South Carolina, pp. 154-169, 1884.

- Clark, W. B., Correlation papers, Eocene: U. S. Geol. Survey Bull. 83, pp. 52-54, 1891.

- Dall, W. H., A table of North American Tertiary horizons: U. S. Geol. Survey 18th Ann. Rept., pt. 2, pp. 330, 341, 1898.
} 
The first use of "Cooper" as a formation name is credited by several writers to Tuomey, but the heading under which he described the deposits now called "Cooper marl" is "Eocene beds of the Ashley and Cooper River." 7 F. S. Holmes, ${ }^{8}$ in 1870 , briefly described the $\dagger$ Cooper River beds and referred the formation to the Eocene. Dall ${ }^{9}$ employed the term " "Cooper River marls" but did not define it; he referred the formation to the lower Oligocene. Chazal, ${ }^{10}$ in describing the phosphate deposits of South Carolina in 1904 made use of the name "Cooper River beds" but contributed little information concerning them. Sloan ${ }^{11}$ in 1907 and again in 1908 used the name "Santee marl" in a restricted sense; he introduced the name f"Mount Hope marl" for the most typical exposures of the original Santee marl of Ruffin, Lyell, and Tuomey; and he used the terms †"Ashley-Cooper phase", †"Ashley-Cooper marls", "Cooper marl", and f"Ashley marl" for the deposits here grouped under the name "Cooper marl." He says:"2

The Ashley marl rests conformably on the Cooper marl, but a plane of division is indicated by a line emphasized by occasional rounded black quartz and phosphate pebbles. *** The Cooper and Ashley marls were deposited in deep water; the Cooper probably represents the expiring expression of the Eocene. The Ashley is slightly suspected of Oligocene antecedents but appears destitute of fossils of specific value to refined discrimination; the underlying layer of pebbles suggests the product of the depression with which the Combahee phase is terminated. The preponderance of similarities, however, indicates that it is very closely allied to the Cooper marl, the chief difference consisting in the gradual increase of phosphoric acid toward the upper surface, and therefore that it is competent to group them as the Ashley-Cooper marl, excluding the thin capping of Miocene marl which was formerly included as a part of the Ashley marl.

Stephenson, ${ }^{13}$ in 1914, applied the name "Cooper marl" to foraminiferal marl "which outcrops in the vicinity of Charleston and which is referable to either the uppermost Eocene or the Oligocene." The name was used in the same sense by Rogers ${ }^{14}$ the same year.

\section{SANTRE LIMESTONE}

GENERAL CHARACTER

The name "Santee limestone" is particularly appropriate because the best and most highly fossiliferous natural exposures of the formation occur along or near the Santee River and because the most

1 Tuomey, Michael, op. cit., p. 162.

a Holmes, F. S., Phosphate rocks of South Carolina and the "great Carolina marl bed", p. 18, Charleston, S. C., 1870.

O Dall, W. H., op. cit., p. 342.

${ }^{10}$ Chazal, P. E., The century in phosphates and fertilizers, a sketch of the South Carolina phosphate industry, p. 24, 1904.

I1 Sloan, Earle, Handbook of South Carolina, pp. 86, 90-91, 1907; Catalogue of the mineral localities of South Carolina, pp. 462-463, 1908.

12 Sloan, Earle, op. cit. (Catalogue), pp. 463-464.

${ }^{13}$ Stephenson, L. W., A deep well at Charleston, S. C.: U S. Geol. Survey Prof. Paper 90, p. 85, 1914.

14 Rogers, G. S., The phosphate deposits of South Carolina: U. S. Geol. Survey Bull. 580, p. 186, 1914. 
common constituent of the formation in that area is limestone. The well-known exposures at Eutaw Springs are regarded as typical.

The color of the Santee limestone ranges from nearly pure white to creamy yellow. Pale-greenish tints, caused by the presence of grains of glauconite, are not uncommon, and deeper greens are occasionally seen. Throughout part of its area the Santee limestone is soft, very homogeneous in composition and texture, and with few bedding planes, but where the formation has been long exposed to the weather, as in the abundant natural exposures near the Santee River, thin ledges of hard limestone, probably casehardened by redeposition of dissolved calcium carbonate, stand out boldly from the softer beds.

In Calhoun and Orangeburg Counties the Santee limestone appears to lie unconformably upon the McBean formation, but exposures of the contact are few and obscure. An irregular line separating coarse glauconitic marl from overlying softer chalky marl at Cave Hall, near Elloree, Orangeburg County, has been interpreted ${ }^{15}$ as an unconformity between the $\mathrm{McBean}$ and the Santee. In Clarendon, Williamsburg, Georgetown, and Berkeley Counties the limestone lies unconformably upon the Black Mingo formation.

The Santee passes beneath the Cooper marl, which probably lies conformably upon it, but no exposure of the contact is known, and the boundary between the two formations shown on the map is conjectural.

Surface exposures afford no adequate measurements of the thickness of the Santee limestone. Lyell ${ }^{16}$ reports 60 feet of limestone visible at Cave Hall, near Elloree, but some of it may be of McBean age. A deep well at Walterboro penetrated 230 feet (depth $210-440$ feet) of soft cream-colored limestone that may be referable to the Santee. The deep well at Charleston ${ }^{17}$ passed through 184 feet (depth 260-444 feet) of alternating hard and soft limestone that apparently is the Santee. Provisionally, 230 feet may be taken as the maximum thickness of the Santee limestone.

The Bryozoa constitute the dominant element in the fauna of the Santee limestone. Canu and Bassler ${ }^{18}$ have described many species from Eutaw Springs and Leneuds Ferry that occur also in the Castle Hayne marl at Wilmington, N. C. Many of these have been found also in the Tivola tongue of the Ocala limestone at Rich Hill and other places in Georgia, and a few ranged as far west as Jackson, Miss. Of the determinable Mollusca, the oysters and pectens are the most numerous. Ostrea sellaeformis is associated in the same

\footnotetext{
2o Sloan, Earle, op. cit. (Catalogue), p. 302.

${ }^{16}$ Lyell, Charles, Geol. Soc. London Quart. Jour., vol. 1, p. 434, 1845.

17 Stephenson, L. W., A deep well at Charleston, S. C.: U. S. Geol. Survey Prof. Paper 90, pp. 69-90, 1914.

18 Canu, Ferdinand, and Bassler, R. S.. North American early Tertiary Bryozoa: U. S. Nat. Mus. Bull. 106,1920 .
} 
beds with $O$. trigonalis Conrad in the Santee area, but it occurs also in the McBean formation. Pecten (Pseudamusium) calvatus Morton, which is widely distributed in the Santee limestone and the Cooper marl, is closely related to and perhaps specifically identical with Pecten scintillatus Conrad, the common species in the Jackson formation of Mississippi. The echinoids are not numerous, and most of the species have been found also in either the Castle Hayne marl of North Carolina or the Ocala limestone of Georgia, Florida, and southeastern Alabama. Periarchus pileus-sinensis (=P. lyelli Conrad), the type of which was found by Ravenel in the Santee limestone, is characteristic of the Tivola tongue of the Ocala limestone in Georgia and is abundant also in Alabama and in Mississippi. Peronella? crustuloides (Morton), also described from South Carolina, is common in the Ocala limestone in Alabama. The type of the cetacean Dorudon serratus Gibbes, a relative of the zeuglodons, was found in the Santee limestone. The widespread Jackson zeuglodon Basilosaurus cetoides (Owen) bas not been found in South Carolina.

Along the Santee River indications of the Santee limestone are first seen in the vicinity of St. James Ferry and Lynches Ferry (formerly called Mazycks Ferry), on the road from Charleston to Georgetown, about 10 miles from the ocean. From this point exposures are numerous up the river to Creston, about 80 miles (air-line distance), except for an interval of about 30 miles between the Atlantic Coast Line Railroad and the Santee Canal in which the formation is absent. From Leneuds Ferry, near the crossing of the Seaboard Air Line Railway, the limestone can be traced by a series of sink boles and occasional exposures northward past Suttons, and well drillers report limestone not far below the surface as far north as Lane.

\section{WILLIAMSBURG COUNTY}

Leneuds Ferry (134).-The following section at Leneuds Ferry, Santee River, on the Williamsburg-Georgetown county line, is adapted from Sloan: ${ }^{19}$

Section of Santee limestone at Leneuds Ferry

4. Irregular layer of greensand.

3. Ledge of very hard crystalline marl projects over the west line of the Santee River; also exposed along the scarp of the swamp east of the Santee River. Contains calcium carbonate 89.64 percent . . . . . . . . . . . . . . . . . .

2. Soft yellow marl with some rounded fragments. Contains calcium carbonate 85.57 percent

1. Marl enclosing glauconite; undulation of the surface of this stratum causes its thickness above the zero water level (5 feet mean low tide) to vary

10 Sloan, Earle, op. cit. (Catalog), p. 307. 
Sloan says:

This series of marls irregularly extends down the westerly valley of the Santee River, with exposures at Echaw Creek and finally at Wambaw Creek [both in Berkeley County], where the glauconitic phase alone survives and passes below the valley line.

The rock at Leneuds Ferry is notable for the profusion of Bryozoa that it contains. Canu and Bassler ${ }^{20}$ list 67 species from it, of which 14 are peculiar to it, 28 occur also at Eutaw Springs, and 47 at Wilmington, N. C.

Doctor Lake (135).- On the bank of Doctor Lake, about 1 mile north of Leneuds Ferry, the Santee limestone rises 18 feet above the water. The lower 5 feet consists of hard bluish-gray crystalline limestone containing Bryozoa and grains of glauconite. This bed is probably bed 3 of Sloan's section at Leneuds Ferry, 1 mile below. Except for a few locally indurated layers, the upper part is soft white limestone that resembles the Tivola tongue of the Ocala limestone in Georgia and, like it, is loaded with Bryozoa. Other fossils seen include fragments of oysters, a Terebratulina (probably T. lachryma), and a Spondylus. The Santee limestone is overlain by 2 or 3 feet of river sand and gravel that extends to the surface of the flood plain.

Rock Spring (136).-A thickness of 5 feet of soft white limestone similar to that on Doctor Lake is exposed at Rock Spring, on land owned by S. R. Walters, at the edge of Santee Swamp about 4 miles above Leneuds Ferry. As at the localities lower down, the rock is a mass of Bryozoa. Similar limestone is said to crop out on the land of S. L. Parsons, 3 miles above Rock Spring. At Parsons Mill, near Suttons, limestone was struck in a well 8 feet below the surface.

Lane.-Well drillers report having passed through 20 feet of limestone in wells on the divide between the Black and Santee Rivers east of Lane. Surface indications of this limestone are afforded by numerous sink holes southeast of Lane. Sinks were noticed along the Santee Road 11/2 miles west of Suttons and also along the road from Suttons to Kingstree, soutb of the railroad from Georgetown to Lane.

\section{CLARENDON COUNTY}

Wyboo Swamp (137). - What seems to be the feather edge of the Santee limestone was found on the Santee Road at the crossing of Wyboo Swamp, 11 miles south of Manning. It lies unconformably on the Black Mingo formation and is overlain by sand and gravel. Althougb this bed is unlike any other known occurrence of the Santee limestone, it is referred to that formation because it contains Idmonea sp., Cheiloporina sp., Schizopodrella viminea Lonsdale?, and a few other Bryozoa that, with present knowledge, according to

20 Canu, Ferdinand, and Bassler, R. S., op. cit., pp. 20-33. 
R. S. Bassler, who examined the collection, cannot be other than Jacksonian. The section is as follows:

\section{Section on Wyboo Swamp, 11 miles south of Manning}

Sunderland (?) formation (Pleistocene):

5. Fine pebbly incoherent sand passing into yellow sandy

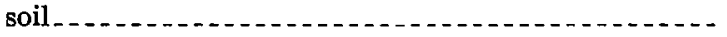

4. Fine transparent quartz sand in bluish-white plastic clay; becomes coarser above and contains coarse gravel 10 feet from top...........................

Feet

23

Santee limestone (Eocene):

3. Patches of glauconite and hard masses of sponges and Bryozoa embedded in bluish-white unctuous clay and quartz sand. The transition to bed 4 is rather abrupt, but there is some intermingling with it.....

Unconformity.

Black Mingo (?) formation (Eocene):

2. Chocolate-colored crumbly shale ............... 5

1. Concealed to water level in Wyboo Swamp ......... 10

Potato Creek and Scotts Lake.--Ruffin ${ }^{21}$ states that marl shows in many places in and along the borders of Potato Creek, and that at Scott Lake, an oxbow of the Santee River 31/2 miles southwest of St. Paul, the marl lies from 4 to 8 feet below low water.

\section{BERKELEY COUNTY}

Santee River.-According to Tuomey, ${ }^{22}$ the Santee limestone is found in the bed of Wambaw Creek, which separates Berkeley County from Charleston County; at Watahoun Creek (Chicken Creek?), a cut-off of the Santee River; at Moores, about 1 mile below the mouth of Echaw Creek; and in the bed of Echaw Creek. Below Gourdin's Ferry (probably near St. Stephen), Tuomey saw a section 15 feet thick composed of a 4-foot bed of compact white marlstone, passing downward into a conglomerate of calcareous pebbles and rounded fragments of indurated green sand with shark teeth, and at the bottom a 5-foot bed of green sand mixed with marl, which rested upon a "thick bed of dark-gray hard marl, altogether different from any seen on the river", containing casts of Venericardia "planicosta". This lowest bed may be the top of the Black Mingo formation.

Fair Spring (138).- The E. J. Dennis plantation, known as "Fair Spring", extends from Macbeth to the old Santee Canal and is crossed by the Biggin Church road. The spring from which it takes its name lies west of the road, about 1 mile from Macbeth. It boils up through a hole about 1 foot square in rock that appears to be limestone but is not readily accessible. There are said to be several old marl pits, now overgrown, on the plantation, some of which were

n Ruffin, Edmund, op. cit., p. 16.

2 Tuomey, Michael, op. cit., p. 155. 
dug during the 1840's, when it was the home of Robert W. Mazyck. The old Mazyck place is noteworthy for having furnished the type of the zeuglodont cetacean Dorudon serratus Gibbes and probably also that of the echinoid Peronella (?) crustuloides (Morton). Other fossils credited to this locality are Gryphaea mutabilis Morton, Terebratula harlani Morton var. b, Periarchus lyelli (Conrad), Pecten perplanus Morton, and casts of Venericardia "planicosta (Lamarck)" and Plagiostoma gregale Morton, but some of these may not have been correctly identified. According to Ruffin, ${ }^{23}$ Gibbes, ${ }^{24}$ and Tuomey, ${ }^{25}$ the materials penetrated in the pits consisted of partly indurated glauconitic marl, 4 to 8 feet thick, resting on white bryozoan limestone.

Pooshee (139). - The Santee limestone underlies part of the Pooshee plantation, which extends eastward for 4 miles from Santee Canal, 6 to 7 miles north of Pinopolis. Tuomey ${ }^{25}$ lists several species of fossils from it.

\section{ORANGEBURG COUNTY}

Eutaw Springs (140).-Eutaw Springs, famous as a battle ground of the Revolution, is also one of the classic localities of American geology. The deposits here may be considered typical of the Santee limestone. The main spring boils up as a bold stream into an oval basin, at the farther end of which it sinks and flows underground for 100 yards, to reappear as a good-sized creek tributary to the Santee.

On the banks of the springs and of the branch flowing from them calcareous marlstone is exposed to a maximum observed height of 20 feet above water level. The lower 16 feet consists of white to creamcolored limestone composed largely of Bryozoa and other organic remains. Most of this is loosely compacted, but parts of it are locally indurated into hard rock. The upper 4 feet, more or less, contrins large grains of glauconite that impart a pale-green color to the rock, which is a soft argillaceous marl or limestone. This upper bed contains small oysters and worm tubes. A list of species collected from the beds follows:

7867. Eutaw Springs, 3 miles northeast of Eutawville; C. Wythe Cooke, collector, 1917:

Ostrea trigonalis Conrad

Ostrea sellaeformis Conrad

Pecten (Pseudamusium) calvatus Morton

Pecten deshayesii Lea

Pecten sp.

Plicatula sp.

Cardium sp.

Bryozoa, many species

Sismondia plana Conrad?

The Bryozoa that have been listed ${ }^{20}$ from Eutaw Springs number 58 species; of these 43 occur also in the Castle Hayne marl at Wilmington, N. C., 28 occur in the Santee limestone at Leneuds Ferry,

12 Ruffin, Edmund, op. cit., p. 15.

" Gibbes, $R_{i} W$., Description of the teeth of a new fossil animal found in the greensand of South Caro lina: Acad. Nat. Sci. Philadelphia Proc., vol. 2, pp. 254-256, 1845.

2s Tuomey, Michael, op. clt., p. 156.

* Canu, Ferdinand, and Bassler, R. S., op. cit., pp. 20-33. 
and 9 have not been listed elsewhere. Although more species are credited to Wilmington than to Leneuds Ferry the rock at Eutaw Springs really contains a greater proportion of the Leneuds Ferry. fauna (about 42 percent) than of the Wilmington fauna (about 25 percent), for the latter includes 168 species, whereas only 67 have been listed from Leneuds Ferry.

Ferguson (141).- Exposures of the Santee limestone were found a short distance below the old trestle of the tram road at Ferguson. The rock consists of bryozoan limestone with one or more ledges of very hard limestone. As the face of the rock was coated with mud when visited, opportunities for examining it were much less favorable than at Eutaw Springs, about 2 miles distant.

The bryozoan limestone at Ferguson was referred to the †Mount Hope phase by Sloan, ${ }^{27}$ but this name is regarded as a synonym of "Santee limestone", which has many years' priority.

Santee River.-Limestone is exposed along the bank of the Santee River at intervals from Ferguson to Big Poplar Creek, which separates Orangeburg County from Calhoun County. Sloan ${ }^{28}$ describes the occurrence of limestone or marl at Whaley's mill on Poplar Creek (142), at Pinckney Landing (143), at Tates Landing (144), at Vances Ferry (145), and at a point 3 miles northwest of Eutawville (146). Of these localities I visited only Whaley's mill and Tates Landing. High water in the Santee River concealed the lower beds.

At Tates Landing, $11_{2}^{\prime}$ miles northeast of Mellicans, a few thin ledges of hard gray to cream-colored limestone were visible, but most of the bluff was covered. Some poorly preserved fossil oyster shells (probably Ostrea sellaeformis) were scattered about.

The site of Whaley's old mill is on Big Poplar Creek at the crossing of a road on the county line 4 miles east of Elloree. Soft white to yellowish limestone containing small grains of glauconite is exposed on the north side of the road at the west end of the bridge to a height of 16 feet above water level. Sloan refers the lower part of the section to his †Warley Hill marl because of its content of glauconite, but it does not appear to differ from the Santee limestone and contains even less glauconite than the upper part of the rock exposed at Eutaw Springs. A fragment of Pecten membranosus? and a small Terebratulina? were found here.

Jenkins Hill (147).-On a branch of Big Bull Swamp, 6 miles northeast of the Southern Railway station at Orangeburg and 21/4 miles southeast of Jamison, are several small pits from which white limestone or marl was formerly dug. The pits are on the west bank of the stream a few hundred yards below the crossing of the Belleville Road at the foot of Jenkins Hill. The pits are now completely overgrown, and most of them contain water, but small lumps scattered on the

$n$ Sloan, Earle, op. cit. (Catalogue), pp. 304, 462.

18 Idem, pp. 302-304. 
dump indicate that the rock dug was soft white yellowish limestone containing oyster shells. Frank Burns, of the United States Geological Survey, many years ago collected from this place oysters that appear to be Ostrea sellaeformis but are not well enough preserved for precise determination. The formation is probably the Santee limestone.

\section{CALHOUN COUNTY}

Creston (148).-Soft creamy-yellow marl containing a little glauconite and a few fragments of oyster shells is exposed below the railroad tracks about half a mile north of the station at Creston. The top of the marl is 35 feet lower than the station. The marl is overlain by sand that extends about 15 feet above the tracks at the station.

An old well on the Belle Broughton plantation, half a mile south of Creston, on a branch of Halfway Swamp 400 yards northeast of the Moncks Corner Road, passes through the following materials:

Log of well on Belle Broughton plantation (149)

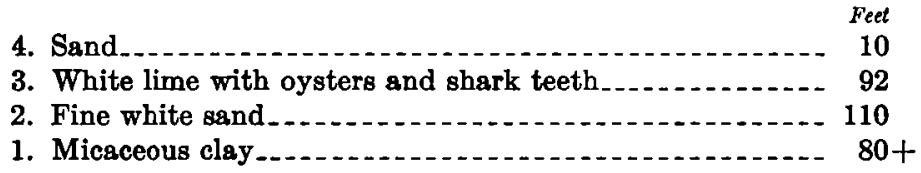

About 100 yards downstream from the well and 10 feet lower than its mouth 35 feet of fine granular cream-colored limestone or marl containing fossils characteristic of the Santee crops out. The following fossils were collected here:

7990. Belle Broughton plantation, half a mile southeast of Creston; C. Wythe Cooke, collector, 1917:

Kleidionella lobata Canu and Bassler
Bryozoa, several other species
Terebratulina lachryma (Morton)?, worn specimen
Ostrea trigonalis Conrad
Ostrea sellaeformis Conrad
Pecten deshayesii Lea
Crab claw

Lumps of coarse gray-green glauconitic sandy marl found on the dump from an old quarry and probably dug from a slightly lower bed than the marl from which the fossils in the preceding list were collected contain Ostrea sellaeformis divaricata Lea (station 7989). This glauconitic bed may be the McBean formation.

COOPER YARL

GENERAL CHARACTER

The Cooper marl is the youngest formation of Jackson age in South Carolina. As already stated, it overlies the Santee limestone, the lower formation of Jackson age, and is probably in part contempora- 
neous with the Barnwell sand, although the top of the Barnwell may not be as young as the upper part of the Cooper.

The Cooper marl is exposed on the Cooper River (from which the formation takes its name) and on Goose Creek, the Ashley River, the Edisto River, and some of their tributaries, but elsewhere it is generally covered by deposits of Miocene or Pleistocene age. Several notable artificial exposures have been made, such as the marl pits at Lambs, Ingleside, and Woodstock.

Rogers ${ }^{29}$ describes the Cooper marl as follows:

The formation consists of over 100 feet of grayish green marl; the lower part (the Cooper marl of Sloan) is greenish drab in color and somewhat plastic when wet but lighter-colored and fairly hard when dry. It commonly contains about 75 percent lime carbonate and about 2 percent lime phosphate. The upper part of the formation (the Ashley marl of Sloan) is dull olive-green and semiplastic when wet and drab when dry. The content of lime carbonate is somewhat lower than that of the lower division of the formation, but the phosphate is considerably higher, commonly exceeding 5 percent.

Small phosphatic lumps are locally abundant; in some analyses the amount of $\mathrm{P}_{2} \mathrm{O}_{5}$ is recorded as 15 percent. Phosphate in such large proportions is found only near the surface and is apparently the result of enrichment after the deposition of the marl. The extent of phosphatization that the rock has undergone was used by Sloan as the principal criterion in distinguishing between his †Ashley marl and Cooper marl, the greater amount of phosphate being characteristic of his $\dagger$ Ashley.

The greatest thickness of the Cooper marl exposed in any one section was visible in the marl pit at Woodstock, which was 76 feet deep in 1917. The city well at Walterboro penetrated 150 feet (depth 60-210 feet) of yellowish-gray or drab clayey Cooper marl that lies upon 230 feet of cream-colored Santee limestone. A deep well at Charleston passed through 175 feet of Cooper marl and 184 feet of Santee limestone.

\section{BERKELEY COUNTY}

Biggin Swamp.-The northernmost exposures of the Cooper marl are near the old Santee Canal. The road scraper has laid bare the Cooper marl on the side of United States Highway 52 at the southwest end of the fill leading to the bridge over the canal, 2 miles northeast of Moncks Corner (150). The marl contains many shells of Pecten calvatus Morton and is overlain by 10 to 15 feet of coarse pebbly sand.

About 1 foot of Cooper marl is visible near the top of the bluff 15 to 20 feet high east of Santee Canal half a mile north of Biggin Church

\footnotetext{
n Rogers, G. S., The phosphate deposits of South Carolina: U. S. Geol. Survey Bull. 580, pp. 186-187, 1914.
} 
(151). The surface of the rock is hard and light gray, but freshly dug pieces are softer and cream-colored.

At Steep Bluff (152), on the west side of Biggin Swamp near the end of the Santee Canal, three-quarters of a mile below the highway bridge, the Cooper marl is bare from the water's edge to a height of about 30 feet. The best exposures are at the upper end of the bluff.

Moncks Corner (153). - Cooper marl from a pit on United States Highway 52 about 1 mile south of Moncks Corner was used in 1928 to build the road from Moncks Corner to Pinopolis. The rock is soft enough to be excavated with a steam shovel. When freshly dug it is brownish, but it becomes light gray when dry. It contains many small brown particles of phosphate. In October 1928 the pit was 10 or 15 feet deep. The sandy overburden was as little as 2 feet at some places. The marl contains small Foraminifera and shark teeth.

West Branch of Cooper River.-The Cooper marl is said to extend along the West Branch of the Cooper River from the neighborhood of Bullhead Run (154) above Wadboo Bridge to Strawberry Ferry (155), below the crossing of the Seaboard Air Line Railway. Ruffin, Tuomey, and Sloan describe several exposures within this interval, none of which present any marked peculiarities. The top of the marl is irregular, but it descends gradually toward the south from a height of 36 feet above low water on Bullhead Run to $7 \frac{1}{2}$ feet above low water at Strawberry Ferry. At the Biggin Church parsonage (154) 32 feet of marl is exposed; at Gippy (156), 2 miles southeast of Moncks Corner, 17\%2 feet; at Lewisfield (157), a mile downstream from Gippy, the marl emerges 12 feet above low tide. The bluff at Mepkin (158) shows about 9 feet of marl. The marl on the Cooper River is described as yellowish and pulverulent. Analyses quoted by Sloan ${ }^{30}$ show that the marl runs as high as 79 percent calcium carbonate.

East Branch of Cooper River.-Exposures of the Cooper marl on the East Branch of the Cooper River are few. Sloan ${ }^{31}$ mentions only two localities along this stream--Hugers Bridge (159), 4 miles east of Cordesville station, and Richmond plantation (160), on the west bank of the river several miles below Hugers Bridge. At neither locality is more than a foot or two of the rock exposed.

Goose Creek (161).-At the old Charleston waterworks on Goose Creek near Saxon the Cooper marl is exposed to a thickness of about 12 feet above low tide. The marl contains Pecten (Pseudamusium) calvatus Morton and presents no unusual features.

Ingleside (162).-A marl pit at Ingleside, now abandoned and full of water, has yielded a number of fossils from the Cooper marl. The list of species collected here follows:

a Sloan, Earle, op. cit. (Catalogue), p. 293.

in Idem, p. 295. 
5252. Marl pit, Ingleside, S. C.; Earle Sloan and T. W. Vaughan, collectors:

Balanophyllia? sp.

Balanus peregrinus Morton.

Epitonium chamberlaini Johnson.

Lyria sp.

Cassidaria? sp.

Ficus sp.
Anomia jugosa Conrad.

Ostrea sp.

Ostrea carolinensis Conrad.

Pecten calvatus Morton.

Pecten sp.

Woodstock (163).-A pit said to be 76 feet deep has been excavated in the Cooper marl at Woodstock, three-quarters of a mile northwest of Ingleside. The rock is very homogeneous finely granular lightbrownish marl, weathering gray. It resembles the marl of bed 2 of the section at Lambs (p. 87). No line of division was noticed in this pit such as was seen at Lambs. The type specimen of Xenorophus sloanii Kellogg, an archaic toothed whale, was found 15 feet below the top of this pit.

\section{DORCHESTER COUNTY}

Edisto River.-For a distance of about 3 miles above the mouth of Cattle Creek the Edisto River hugs the left side of its flood plain and at several points touches the 40 -foot bluff that bounds it. Pleistocene terrace deposits form the upper part of the bluff, but the lower 10 feet is cut into the Cooper marl. At Beulah Church, 43/4 miles south of the point where the Southern Railway crosses the Orangeburg County line, only 2 feet of pale-brown, very sandy finegrained marl is exposed at the base of the bluff. The hardened parts of the marl contain indistinct impressions of mollusks. At a boat landing half a mile southeast of Beulah Church about 5 feet of marl is exposed. A quarter of a mile below the landing, where the river again eats into the bluff, a landslide in 1928 laid bare a clean cut in which the following section was measured:

Section on Edisto River 1 mile west of Cattle Creek and 0.7 mile southeast of Beulah Church (164)

2. Pleistocene: Coarse gray sand enclosing pellets of gray Feet clay; passes below into fine gray sticky sand......... 28

1. Eocene (Cooper marl): Finely granular olive-drab marl containing Foraminifera (station 11856); to water level, about. . . . 10

According to Sloan ${ }^{32}$ the Cooper marl is underlain by gritty graygreen glauconitic marl that is exposed along the foot of the bluff when the water in the river is unusually low. Sloan referred the marl to his †Warley Hill phase (the McBean formation of this report) because of its lithologic character. To account for its presence so far south, he postulated an anticlinal uplift along the Edisto River

\footnotetext{
o Sloan, Earle, op. cit. (Catalogue), pp. 278-280.
} 
(the "St. Georges anticline" ${ }^{33}$ ) that prevented the deposition of the Santee in this area. A simpler explanation and one that does no violence to any known geologic facts is that this glauconitic bed is part of the Cooper marl.

The Cooper marl is exposed in the bed of Cattle Creek at the bridge half a mile from the Edisto River (165) and in the bed of the river at Raysor Bridge (166), Stokes Bridge (167), and Scotchmans Bluff (168).

Four Hole Swamp (169).- On the west bank of Four Hole Swamp at the crossing of the road from Orangeburg to Summerville, 2.7 miles east of Dorchester, 23 feet of compact, finely granular brown marl is overlain unconformably by fine white to reddish micaceous sand. The marl contains shark teeth, casts of mollusks and corals, Pecten calvatus Morton, Terebratulina sp., and many phosphate nodules. The bluff at this point rises about 45 feet above the water in the creek. A section is given on page 148.

According to Sloan, ${ }^{34}$ the Cooper marl is exposed at intervals below the bridge to the Edisto River, 7 miles distant.

Givhans Bridge (170).-At Givhans Bridge, on the Edisto River 2 miles below the mouth of Four Hole Swamp, the Cooper marl is exposed in the gorge of a small stream along the old and new roads leading down to the bridge, also in a bluff on the river about 300 yards above the bridge. The section is as follows:

Section on east bank of Edisto River at Givhans Bridge

[Miocene fossils identifled by W. C. Mansfield]

Penholoway formation (Pleistocene):

Feet

5. Fine brown sand and clay; about $\ldots \ldots \ldots$

Unconformity.

Duplin marl (Miocene):

4. Soft and hard gray or white marl containing Pecten eboreus, $P$. raveneli, Amusium mortoni, Arca improcera?, and phosphate pebbles; the harder parts are very similar to the oyster bed of the Cooper marl, but the softer parts are more marly; exposed along old road............................. 0-2

Unconformity.

Cooper marl (Eocene):

3. Hard yellow marlstone containing large Ostrea podagrina and many Bryozoa; perforated by tubular borings, some of which contain phosphate pebbles (station 11858)

0-2

2. Soft, plastic, puttylike brownish to cream-colored marl containing small Foraminifera (station

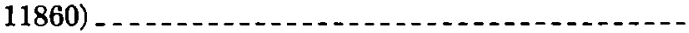

1. Soft, finely granular brownish to cream-colored marl. 
Beech Bank (171).-According to Sloan, ${ }^{35}$ yellow-white marl similar to that at Scotchmans Bluff and Givhans Bridge is exposed on the west side of the Edisto River at Beech Bank, 0.7 mile above Parkers Ferry, which is at the Dorchester-Charleston county line. The marl is said to rise 5 feet above water level.

Ashley River.-The first outcrop of the Cooper marl found on descending the Ashley River, according to Sloan, ${ }^{36}$ is at Schultzes Lake (172), a mile above Slans [Blands?] Bridge, 6 miles southwest of Summerville. There are several exposures between Schultzes Lake and Bees Ferry (177), in Charleston County. At Bacons Bridge (173) the marl extends about $10 \frac{12}{2}$ feet above the level of mean low tide. ${ }^{36}$

\section{CHARLESTON COUNTY}

Cooper River.-In the excavations for the dry dock and power plant at the navy yard at Charleston, T. W. Vaughan, ${ }^{37}$ in November 1907, observed the following section:

Recent:

Section at Charleston Navy Yard (174)

4. Tidal flat with recent shells and muck

Pleistocene:

3. Yellow sands mixed with fine-grained white sands.

Not exposed at front edge of dock, but back from

front attains a thickness of about

2. Phosphate pebbles (not in place) . . . . . .

Eocene (Cooper marl):

1. Light gray-green marl; plastic when wet; lighter in color and friable when dry. Contains Pseudamusium sp

One of the cotypes of Epitonium chamberlaini Johnson ${ }^{38}$ came from the Charleston Navy Yard, and E. charlestonensis occurs there also.

Lambs (175).-The Cooper marl has been excavated for fertilizer at several places along or near the Ashley River. It is overlain by phosphate-bearing marl that appears to be of Miocene age. A marl pit that may be taken as typical of those in this vicinity is the quarry of the Charleston Mining \& Manufacturing Co. at Lambs, shown in plate 14, $B$. The section, as recorded in June 1917, is as follows:

\section{Section in marl pit at Lambs}

Pleistocene or Recent:

Feet

4. Brown clay loam

Miocene (Hawthorn formation):

3. Fine gray sandy marl containing inclusions of harder white marl and many irregular phosphatic nodules and shark teeth........

ss Sloen, Earl, op. cit. (Catalogue), p. 284.

2 Idem, p. 286.

n Unpublished fleld notes.

28 Johnson, C. W., Now fossil species of the genus Epitonium from South Carolina: Nantilus, vol. 45, pp. $0-10,1931$. 
Section in marl pit at Lambs-Continued

Unconformity.

Eocene (Cooper marl):

Feet

2. Soft, finely granular brownish marl containing phosphatic nodules in the lower part. Contains an abundance of Foraminifera and Pseudamusium sp_ 25

1. Soft plastic argillaceous light-gray marl; massive, homogeneous and putty like. Contains many Foraminifera and Pseudamusium sp. To bottom of pit_ 161/2

Bed 1 is separated from bed 2 by a distinct line, and the beds are characterized by certain differences in lithology. Bed 2 was referred to the †Ashley marl by Sloan ${ }^{39}$ because of its high content of $\mathrm{P}_{2} \mathrm{O}_{5}$, but the differences appear scarcely sufficient to justify applying different formation names; the fossils, so far as they are known, are the same. The rock from these two beds was dried and ground for fertilizer. Bed 3 was mined for phosphate. It contains many shark teeth and casts of mollusks.

Magnolia Gardens (176).--A bluff on the west bank of the Ashley River near Magnolia Gardens and above the bridge of the railway between Bulls Chapel and Lambs shows about 10 feet of gray to yellow granular Cooper marl containing small brown phosphatic grains. At the top of the marl is a ledge of hard cavernous limestone that is probably Cooper, although it may represent the Hawthorn formation. On the surface and in cavities in the ledge are many rounded lumps of phosphate rock that range from small grains to lumps several inches in diameter.

Bees Ferry (177).-At Bees Ferry (Drayton), according to Sloan, ${ }^{40}$ a green-drab marl rises 4132 feet above mean low tide. The rock is the †Ashley marl of Sloan, which is here regarded as part of the Cooper marl. It is overlain by a thin bed of phosphate rock (Hawthorn formation) that has furnished the profusion of shark teeth for which Bees Ferry is noted. ${ }^{41}$

\section{ALLENDALE COUNTY}

Known outcrops of the Cooper marl in Allendale County are confined to the valleys of the Savannah River, Lower Three Runs, and a few of their smaller tributaries, but the marl underlies at no great depth a belt extending eastward from Baldock to the Salkehatchie River. The presence of soluble beds beneath the surface in part of this area is indicated by ponds and sinks.

Baldock (178).-A few feet of soft gray or cream-colored sandy marl is visible in the bed of Miller Creek about 300 feet southeast of the railway station at Baldock. The same rock is exposed to a thickness of about 3 feet at the water tank. An oyster bed 2 feet thick was

s9 Sloan, Earle, oral communicstion.

io Sloan, Earle, op. cit. (Catalogue), p. 291.

11 Tuomey, Míchael, op. cit., p. 165. 
passed through at a depth of 48 feet below the surface in an artesian well at Baldock. As the mouth of the well is about 22 feet above water level in the creek, the shell bed is about 30 feet below the top of the exposure of marl. The marl contains at least 38 species of Bryozoa, of which 29 occur also in the Ocala limestone in Georgia, 16 in the Castle Hayne marl at Wilmington, N. C., 10 at Eutaw Springs, and 8 at Leneuds Ferry; 13 species occur also in the Jackson formation in Mississippi. This fauna most closely resembles that of the Ocala limestone.

\section{BAMBERG COUNTY}

Lemon Creek.-Cedar Springs (179) and Glendale Spring (180), both on the left side of Lemon Swamp, 2 and 4 miles, respectively, southwest of Bamberg, issue from crevices in rock that does not rise above water level at the springs but which is described by Tuomey ${ }^{42}$ as "a rich white marl with green sand above it." The presence of this marl not far beneath the surface is indicated by numerous sinks and ponds that dot the plain in a belt extending across the county from Bamberg to Beaufort Bridge, on the Salkehatchie River.

\section{BARN WELL SAND}

GENERAL CHARACTER

Sloan recognized two divisions in the so-called $t^{\text {"Buhrstone" of }}$ western South Carolina, a lower, his †Warley Hill (the McBean formation of this report), and an upper, which he called $\dagger$ "Barnwell phase" and †"Barnwell buhr sands", from its characteristic development in Barnwell County. ${ }^{43}$ He stated that the Barnwell overlaps the upper [northern] margin of the Santee "marl" and that it appears to be the stratigraphic equivalent of the $†$ Mount Hope marl.44 Subsequent study of the fossils has shown that many of the localities definitely referred by Sloan to the Barnwell really belong to the $\mathrm{McBean}$ formation, and it is difficult to specify any particular locality in South Carolina that can be considered the original type. However, the name "Barnwell" has been adopted in this report in what is deemed to be its original significance-namely, as indicating an Eocene formation composed chiefly of sand that overlies unconformably the McBean formation. This usage is the same as that followed in the description of the deposits of Claiborne and Jackson age in Georgia. ${ }^{45}$

The Barnwell sand transgresses northward unconformably across the McBean formation, the Tuscaloosa formation, and the crystalline

\footnotetext{
12 Tuomey, Michael, op. cit., p. 159.

4 Sloan, Earle, Catalogue of the mineral localities of South Carolina, p. 454, 1908; Handbook of South Carolina, p. 90, 1907.

4 Bloan, Earle, op. cit. (Catalogue), pp. 460, 461.

1s Cooke, C. W., and Shearer, H. K., Deposits of Claiborne and Jackson age in Georgia: U. S. Geol. Survey Prof. Paper 120, pp. 62-56, 1919.
} 
rocks of the Piedmont region. Along its southern boundary the Barnwell probably merges into the Cooper marl, just as in Georgia it merges into the Ocala limestone, although the transition zone in South Carolina is covered by Pleistocene deposits.

The Barnwell formation consists chiefly of fine to coarse reddish pebbly sand, generally massive but in places cross-bedded, and commonly mottled or streaked with gray veins or spots. Thick beds of massive medium to fine-grained orange sand are common, particularly in the area adjacent to the Savannah River. At the base of the formation is a bed or zone of marl or limestone, the continuation of the Ostrea georgiana zone of Georgia, ${ }^{46}$ that appears to be equivalent to the Santee limestone and is probably continuous with it. Exposures of this bed are rare, but the presence of soluble material underground is indicated throughout much of the Barnwell area by many shallow undrained depressions.

In spite of its wide belt of outcrop, the Barnwell sand is not very thick. Its thickness in eastern Georgia is estimated at not over 200 feet, ${ }^{48}$ and in South Carolina it is probably even thinner, as nowhere has a thickness greater than 100 feet been observed.

Fossils are rare in the Barnwell sand. A few fossils, chiefly bryozoans and pectens, have been found in chert at Johnsons Landing (181), on the Savannah River; at Patterson's mill (182), on Lower Three Runs; and at Farrell's pond (184), near the head of Turkey Creek; and a larger fauna, chiefly mollusks, is known at several places in Aiken and Lexington Counties.

The firm, hard argillaceous sands of the Barnwell uphold a rolling plateau (Aiken Plateau) that is deeply trenched by streams and considerably dissected near the larger rivers. The steep slopes afford good drainage, and the swamps bordering streams confined to the Barnwell area are much narrower than those of streams that have cut into the softer sands and marls of the McBean formation.

The principal soil types derived from the Barnwell sand are the red sands and loams called by the Bureau of Chemistry and Soils, "Orangeburg series", which are especially characteristic of the red hills, and the gray or yellowish sands and sandy loams of the soil type called "Norfolk series", which are flatter.

The Barnwell sand dips very gently southward. Because of the lack of recognizable continuous beds it is impossible to make instrumental measurements of the dip of any particular stratum except the very bottom of the formation. The contact of the Barnwell and the McBean formation, which can in most places be recognized without difficulty, slopes southward at a rate estimated at 9 feet to the milelittle greater than the gradient of the streams. No irregularities have been detected in the structure of the Barnwell formation

* Cooke, C. W., and Shearer, H. K., op. cit., p. 64. 


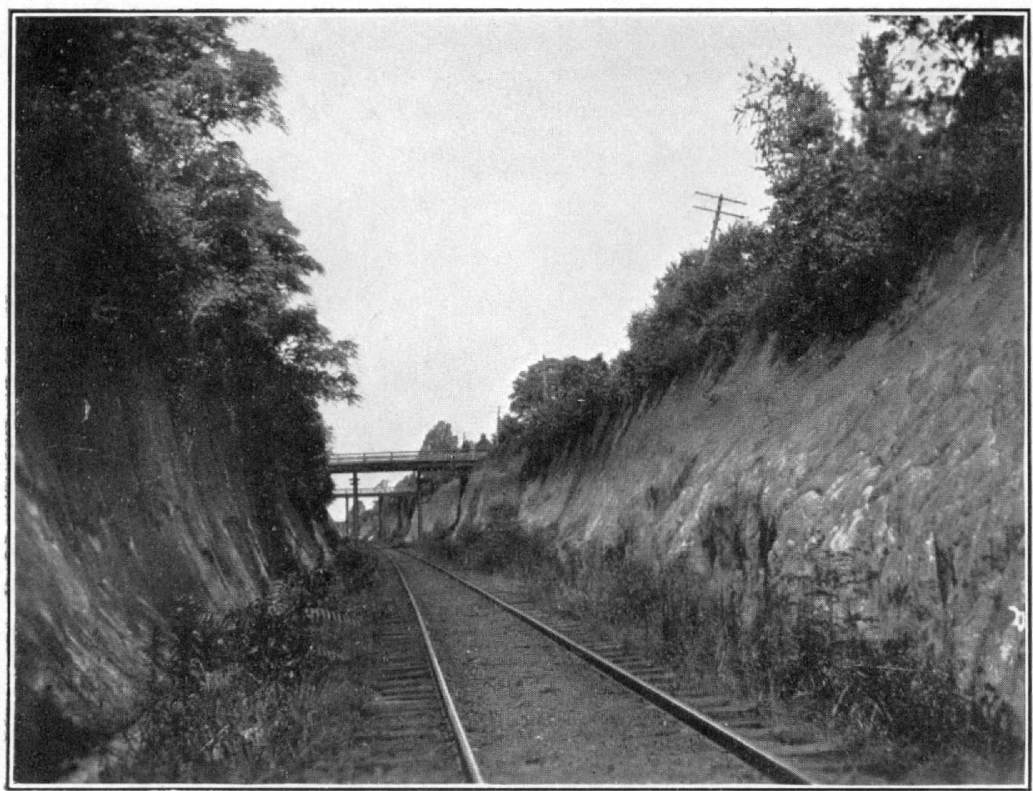

A. BARNWELL, SAND IN RAILROAD CUT AT AIKEN.

l'holorraph by L. W. Stephenson.

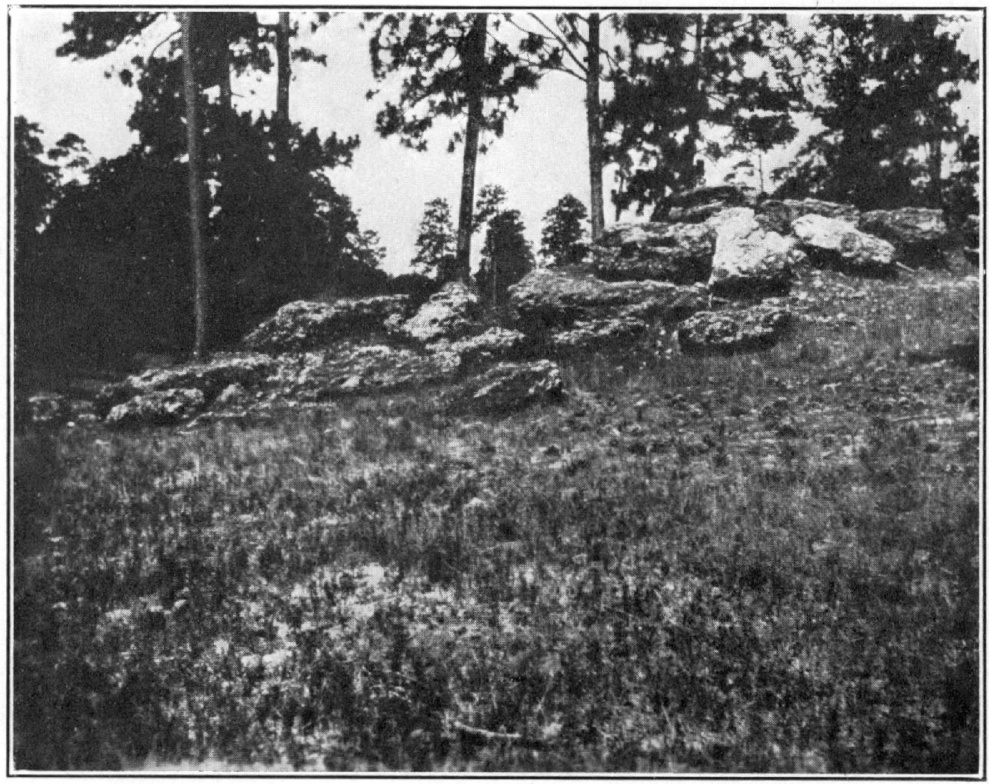

B. SANDSTONE OF BARNWELL AGE ON THE DIBHLE FAHM 5 位 MILES SOUTHEAST OF AIKEN.

Photograph by L. W. Stephenson. 


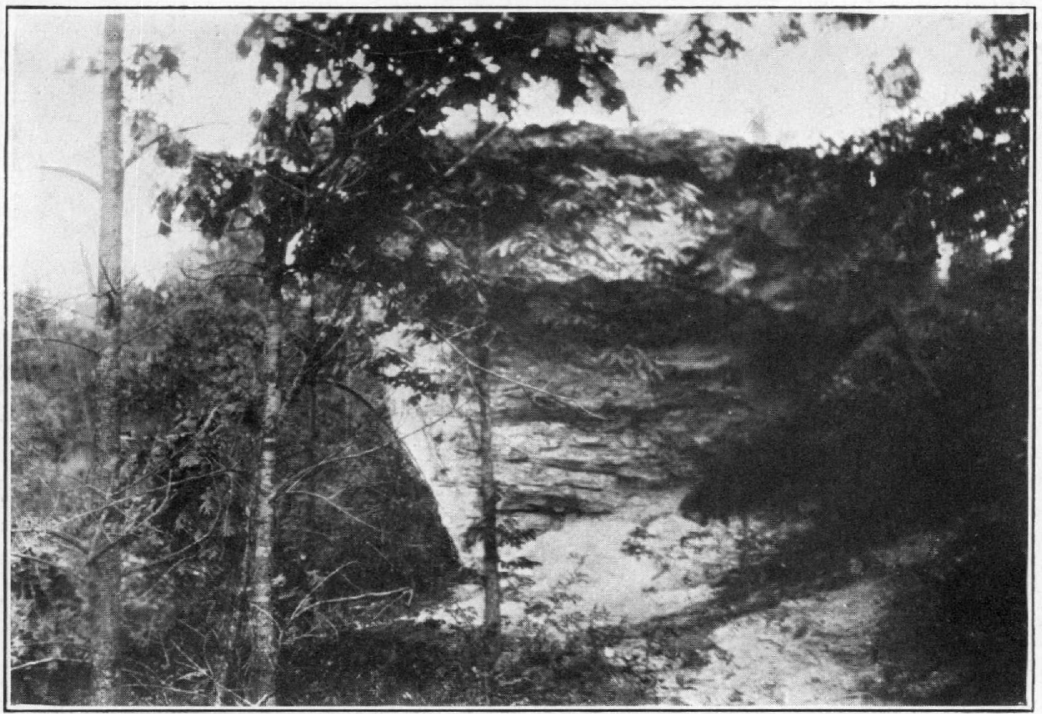

A. BARNWELL SAND NEAR BETHEL CHURCH, LEXINGTON COUNTY.

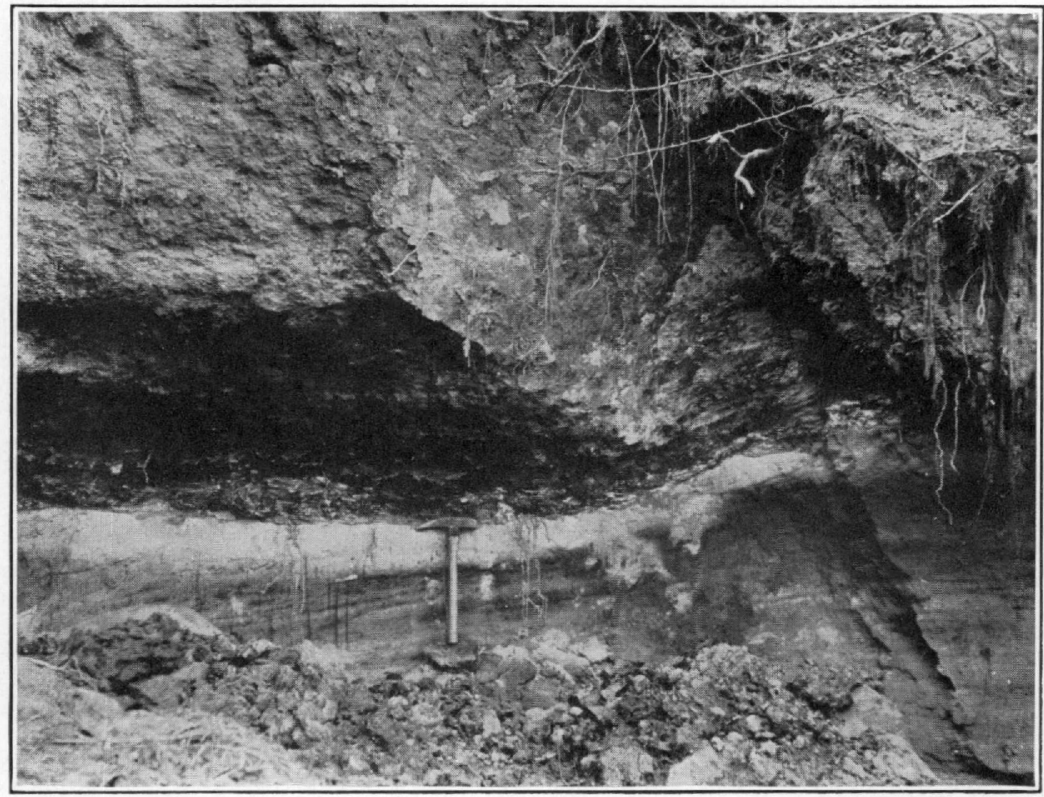

$B$, UNCONFORMITY BETWEEN THE HAWTHORN FORMATION (†MARKS HEAD MARL) AND THE DUPLIN MARL ABOVE ENOCHS WOOD LANDING, SAVANNAH RIVER, 673/4 MILES ABOVE SAVANNAH.

Photograph by L. W. Stephenson. 
ALLENDALE COUNTY

Johnsons Landing (181).--In the bluff on the Savannah River at Johnsons Landing, almost due west of Allendale, great masses of chert lie loose or are embedded in coarse reddish pebbly argillaceous sand. In the fields north of the landing many small chunks of chert contain Lepidocyclina ocalana (identified by T. W. Vaughan), Bryozoa, and other fossils that indicate the Ocala (Jackson) age of the rock. This cherty zone is probably of about the same age as the chert beds of Burke and Jefferson Counties, Ga. ${ }^{47}$

BARNWELL COUNTY

Patterson Mill School (182).--On the road leading down to Lower Three Runs from Patterson Mill School, 5 miles south of Snelling, and in neighboring gullies about 35 feet of massive brick-red dirty sand containing lumps of chert 20 feet above the base is exposed to the foot of the hill. Vaughan ${ }^{48}$ noted poorly preserved fossilsTurritella, Scutella, and Bryozoa-in this rock. The "Scutella" may have been Periarchus lyelli, which is abundant in the chert of the Barnwell formation in Georgia. The chert is evidently derived from sandy limestone.

The sand above the chert contains many large well-rounded pebbles and may be of Pleistocene age. No pebbles were seen in the chertbearing sand.

Barnwell (183).- - In the cut of the Atlantic Coast Line Railroad extending 1 mile east of the station at Barnwell are good exposures of argillaceous sand. At first sight, there appear to be two unconformable beds, but more critical examination indicates that the upper bed has been derived from the lower by weathering.

At the east end of the cut the lower bed consists mainly of tough brick-red argillaceous sand mottled with gray and enclosing a few quartz pebbles as much as half an inch in diameter. Farther west the red bed is replaced by white micaceous sandy clay, which merges laterally into pink argillaceous cross-bedded sand. Near the crossing of the Southern Railway this bed is replaced by massive red sand.

The upper bed is prevailingly yellow. This bed is composed of argillaceous sand, generally finer than the underlying material, and contains a few small quartz pebbles and many lumps and pellets of soft red to black ferruginous sandstone. This bed grades upward into yellow sandy soil.

The most characteristic difference between the two beds is the color, but this is by no means constant. In places the contact of the

47 Cooke, C. W., and Shearer, H. K., op. cit., p. 63.

48 Vaughan, T. W., unpublished field notes, Oct. 16, 1908.

$143491-36-7$ 
two beds is sharp and decidedly undulating, but elsewhere no distinct line of separation can be discerned.

A feature prominent at places in the cut is veining with gray argillaceous sand. The veins appear to follow fissures that cross both beds indiscriminately. The gray color seems to be caused by the leaching of iron by water percolating along the fissures. Patches of gray sand, similar in appearance to the veins but roughly circular in outline, are scattered abundantly throughout the cut. As these patches appear to have no connection with fissures, the gray color may be due to some cause other than leaching.

Farrell's mill (184).-Fossiliferous chert is found in the Barnwell sand on the hillsides above Turkey Creek near Farrell's old mill, 5.3 miles west by south of Blackville. Fragments of this chert have been used in constructing the dam and spillway. The fossils recognized in the chert are Periarchus sp., Turritella sp., and a small Venericardia. Near the dam are exposures of medium-fine massive dirty sand, bright red at the base but passing through shades of orange into light-colored incoherent sand at top. The sand contains a few small fragments of chert and a few pebbles. The total thickness seen here is 15 or 20 feet, but the chert extends somewhat higher on the hills.

A 103-foot flowing well at the mill pond is said to have penetrated chiefly sand.

Lower Three Runs.-A bed of gigantic oyster shells (Ostrea georgiana Conrad) has been seen at several places along Lower Three Runs, notably on the farm of J. W. Ussery, 4 miles northwest of Baldock. This bed is supposed to be the basal member of the Barnwell sand. The place is probably near the Allendale-Barnwell County line.

Savannah River.-As the Savannah River sweeps against the west side of its valley in Barnwell County, there are few exposures on the South Carolina side of the river, which is plastered with terrace deposits. The bluffs on the Georgia side have been fully described elsewhere ${ }^{50}$ and need only be mentioned here. A bed of marl containing many shells of Ostrea georgiana is conspicuous at Shell Bluff. The same bed is exposed farther downstream at intervals to Limekiln Bluff, 11/2 miles below Griffins Landing. This bed was classed by Veatch and Stephenson as part of the McBean formation, but it is now deemed to be the lower part of the Barnwell formation.

Sloan ${ }^{51}$ states that the Santee "marl" containing Ostrea georgiana was struck 15 feet below the surface in a well 1 mile northwest of Robbins.

4 Sloan, Earle, op. cit. (Catalogue), p. 288.

w Veatch, Otto, and Stephenson, L. W., Geology of the Cosstal Plain of Georgia: Georgia Geol. Survey Bull. 26, pp. 243-251, 1911. Dooke, C. W., and Bhearer, H. K., op. cit., pp. 41-81,

1 Sloan, Earle, op. cit. (Catalogue), p. 268. 


\section{AIKEN COUNTY}

Tinker Creek (100).-Rather obscure exposures of the Barnwell sand have been seen on Tinker Creek, a tributary of Upper Three Runs. A section near Cox's Bridge is given on page 58.

Aiken.-The Eocene deposits in the vicinity of Aiken consist chiefly of red sand, with less conspicuous hues of pink and orange, and scattered patches of purple plastic clay. The color and lithologic character suggest derivation from the Tuscaloosa formation or from decayed granitic rocks. At some places the sand is cross-bedded; at other places the bedding is massive. A thickness of about 40 feet of material of this kind is exposed in the Southern Railway cut beneath the bridge at Lawrence Street, overlying white sandy clay (pl. 15, $A$ ). The upper 8 or 10 feet at the bridge is a rather persistent zone of yellowish argillaceous sand containing a few clay inclusions.

At Calico Spring, on the southern edge of Aiken, the strata are more diversifed, as is shown by the following section:

Section at Calico Spring, Aiken (185)

Barnwell sand (Eocene):

6. Red sand (many exposures near town), thickness about. 60

5. Greenish-yellow argillaceous sandstone like bed 3 but a little coarser and harder

4. Greenish-yellow, very compact silicified clay, somewhat resembling fuller's earth, with flinty conchoidal fracture. Contains small irregular pockets of sand.

3. Fine sand in a matrix of greenish-yellow indurated clay - . . . . . .

2. Concealed below top of retaining wall at old pool at spring

Tuscaloosa formation (Upper Cretaceous):

1. White kaolin.

The hard ledges at Calico Spring appear to occupy approximately the same stratigraphic position as those at Dibble's fish pond.

Coker Spring, in Aiken, issues at the top of fine white clayey Cretaceous sand, upon which rests a 4 -foot pebble bed that is overlain by greenish-gray argillaceous sand, which weathers brick-red and contains round ferruginous concretions.

Silver Bluff road.-The Silver Bluff road crosses the Barnwell sand, but the principal valleys along it are cut down to the McBean formation. The contact of the McBean and Barnwell is exposed at several places along this road.

At the intersection of the Silver Bluff road and the Williston road (186), 10 miles south of Aiken, 6 feet of fine reddish-yellow laminated sand and laminae of white clay, supposed to be the McBean formation, is overlain unconformably by a basal conglomerate of very coarse red sand containing pebbles of soft red sandstone and lumps of 
white kaolin. This upper bed is probably the Barnwell sand. Similar exposures were noted near Treadway Bridge (187) over Upper Three Runs, 4.3 miles south of Talatha, and also on the Ellenton road 2.1 miles south of Hawthorne (188).

Dibble farm (189). - On the Dibble farm, 51/2 miles southeast of Aiken, known to Tuomey ${ }^{62}$ as the farm of M. Caradeaux and described also by Sloan, ${ }^{53}$ massive ledges of hard arkosic sandstone (pl. 15, B) at the base of the Eocene are referred to the Barnwell. The sandstone is very similar to the hard ledges in the Barnwell formation at Browns Mountain, Bibb County, Ga. ${ }^{64}$ The following section was measured at the fish pond on the Dibble farm, 6.4 miles by road southeast of the railway station at Aiken:

\section{Section at Dibble fish pond}

Barnwell sand (Eocene):

Feet

5. Massive gray sandstone containing inclusions of greenish silicified clay and a few casts of mollusks and corals; base of bed 10 feet above dam.

4. Coarse red pebbly sand with some clay laminae, about_ 9

3. Concealed, about ............... 10

2. Yellow ferruginous pebbly sand with thin sheets of brown ferruginous sandstone and round lumps of white clay near base......................... 6

Tuscaloosa formation (Upper Cretaceous):

1. Fine gray sand in white clay matrix. Seen

2

A small cut on the road to Aiken 0.8 mile from the Dibble fish pond exposes 5 feet of greenish to red sand underlain by patches of fuller's earth. At the east end of the cut are patches of shells in sand and loose masses of friable sandstone composed chiefly of shells. The whole seems to be a facies of the upper part of the sandstone and lies only a few feet higher than the typical variety. This is probably the place where Sloan and Vaughan collected the shells enumerated in the following list:

4593. Deearadeaux place, 5 miles southeast of Aiken, S. C.; Earle Sloan and T. W. Vaughan, collectors, 1907; identified by T. W. Vaughan:

Lunularia sp.

Platytrochus stokesi (Lea)

Endopachys maclurii (Lea)

Actaeon idoneus Conrad

Terebra sp.

Mangilia sp.

Pleurotoma lonsdalei Lea?

Pleurotoma, 2 sp.

Pleurotoma nupera Conrad

Marginella semen Lea

Caricella pyruloides Conrad? var.
Phos sagenus (Conrad)

Fusoficula texana (Harris)

Mesalia claibornensis Harris

Turritella dutexata Harris

Turritella nasuta Gabb var. (Also at

Pooser's Hill, etc.)

Turritella carinata Lea

Natica semilunata Lea

Dentalium sp. (smooth sp.)

Amalthea sp.

Calyptraea trochiformis Lamarck

6 Tuomey, Michael, op. cit., p. 142.

s3 Sloan, Earle, op. cit. (Catalogue), p. 341.

"Cooke, C. W., and Shearer, H. K., op. cit., p. 47. 
Nucula magnifica Conrad

Nucula ovula Lea

Arca rhomboidella Lea

Trigonarca declivis (Conrad)

Trigonarca sp.

Glycymeris sp.

\author{
Phacoides alveatus (Conrad) \\ Lucina sp. \\ Cytherea aequora Conrad \\ Mactra sp. \\ Corbula extenuata Dall \\ Panope sp.
}

LEXINGTON COONTY

A large outlier of the Barnwell sand caps the highlands south of Edmund, which rise in places to an altitude of 550 feet above sea level. Leesville and Batesburg are built on another outlier that extends into Saluda County; in this part the Barnwell is chiefly red argillaceous sand containing round pebbles.

Bethel Church (190).-An interesting section of the Barnwell sand is exposed at a waterfall in a ravine 200 or 300 yards south of Bethel Church, east of the old road from Lexington to Blackville, 2 miles south of Edmund. The headwaters of Hunt Branch (Second Creek) have cut back into the sandhills and carved fantastic monuments and balanced rocks (pl. 16, $A$ ) in the friable sandstone of the Barnwell formation. The thickness of unweathered rock exposed is about 20 feet. The lower part, at the base of the waterfall, is fine-grained friable saccharoidal sandstone consisting of nearly pure grains of quartz. Some of the overlying material is coarser and contains a few small pebbles. At the top is a ledge loaded with shells and containing a large admixture of greenish clay. Much of this upper ledge has been silicified with chalcedony or opal and is very brittle. Most of the fossils are too poorly preserved for identification, and others are probably undescribed. The only species identified is Volutocorbis petrosus (Conrad), a species very common in deposits of Claiborne and Jackson age. Other genera recognized (station 7732) are Endopachys, Turritella (two species, one of which occurs also at Early Branch), Fissuridea, Nucula, Glycymeris, Corbula, Venericardia, Crassatellites, and several species of the Veneridae.

South of the waterfall and about 30 feet higher is an excaration for road metal made in 6 or 8 feet of coarse mottled red and white pebbly argillaceous sand that becomes yellow toward the top. The waterfall is about 480 feet above sea level.

Leesville.-Sloan ${ }^{55}$ describes a 12-foot ledge of white arkosic quartzite overlying 12 feet of silicified yellowish clay in the valley of Hell Hole Branch, a tributary of Lightwood Creek, 3 miles southeast of Leesville. From the description, this rock would seem to be similar to that at Bethel Church, and it is accordingly referred tentatively to the Barnwell sand.

\footnotetext{
ss Sloan, Earle, op. cit. (Catalogue), pp. 342-343.
} 


\section{OLIGOCINE SERIES}

According to present usage, the only representative of the Oligocene series in the southeastern part of the United States is the Vicksburg group. For a number of years deposits of the age of the Tampa limestone and the Alum Bluff group of Florida were included in the Oligocene series, but these deposits are now placed in the lower and middle Miocene, because the arbitrary division between the Oligocene and the Miocene in America has been shifted downward in order to conform to the standard classification in Europe. This change in classification does not involve any shift in the relative positions of these deposits in the correlation tables.

The Vicksburg group is most completely developed in Mississippi and Alabama. The invading sea of Oligocene time appears to have encroached upon the land first near the present site of the AlabamaMississippi State line and to have spread gradually on both sides of that line. It extended farthest east in the later part of the Oligocene, when it reached at least as far as Allendale County, S. C. Its deposits west of the Mississippi River are, for the most part, concealed by overlapping younger formations, but they have been recognized as far away as Mexico. The current classification of the Vicksburg group is shown in the following table. 
Correlation of the Vicksburg group

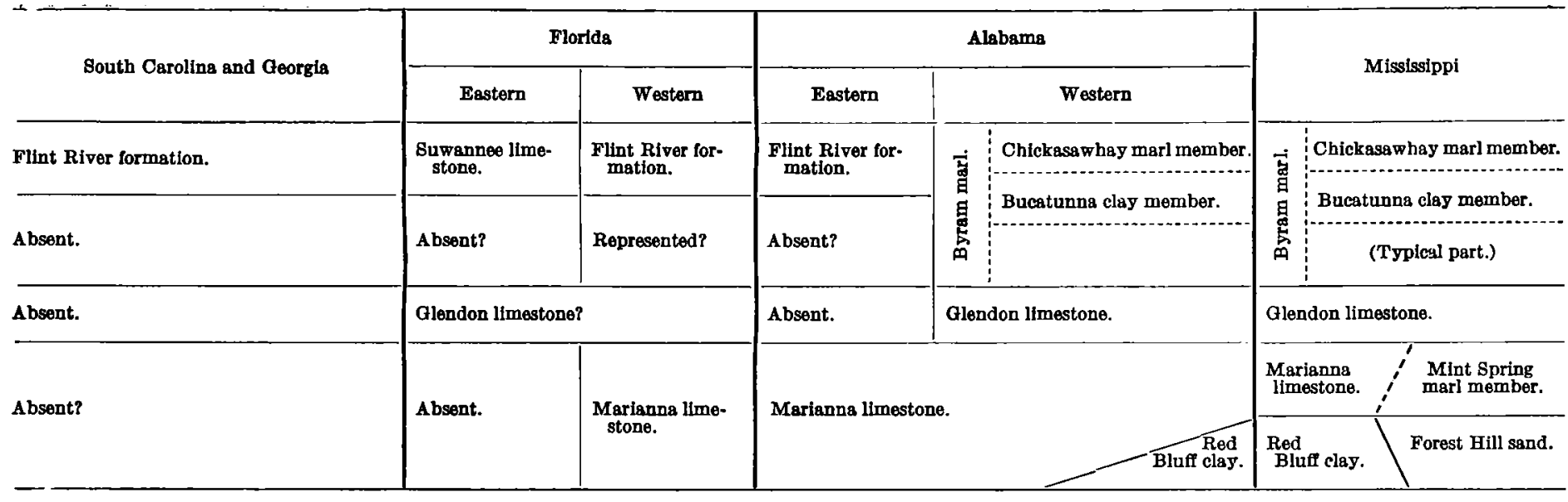


The only representative of the Oligocene series in South Carolina is the Flint River formation, ${ }^{56}$ which is tentatively regarded as equivalent to the upper part of the Byram marl, of upper Oligocene age. The formation is typically developed along the Flint River in the vicinity of Bainbridge, Ga., from which it extends northeastward across Georgia and into South Carolina and westward into southeastern Alabama and northern Florida. In South Carolina the formation occurs only in a narrow strip bordering the Savannah River in Allendale County from the vicinity of Johnsons Landing (181) to Cohens Bluff (191). Exposures are not numerous and consist chiefly of broken lumps of yellow vitreous chert in reddish-yellow sand. The chert is sparingly fossiliferous, but most of the fossils are unrecognizable. Casts of Lepidocyclina, Stylophora, and mollusks were seen in large lumps of chert piled up in a fence corner on the River Road between Watch Call Branch and King Creek, and Vaughan ${ }^{67}$ reports Stylophora tampaensis Vaughan from Cohens Bluff.

Sloan ${ }^{58}$ very briefly described the formation under the name "Kings Creek phase" but included in it cherts at Johnsons Landing and McBean, Ga., that are now referred to the Barnwell formation.

Although little is known from actual observation of the stratigraphic relations of the Flint River formation in South Carolina to formations above and below it or of its thickness, the formation must be separated by an unconformity from the Barnwell sand, which underlies it, because the Marianna limestone, which normally underlies the Byram marl, is absent from South Carolina. The Flint River formation in South Carolina is also separated from the overlying Hawthorn formation by an unconformity, because of the absence of the Tampa limestone in South Carolina. The thickness of the Flint River formation in South Carolina probably does not exceed 50 feet and may be considerably less.

The Flint River formation is placed opposite the Chickasawhay marl member of the Byram marl in the accompanying correlation table of the Vicksburg group, although the evidence that such is its correct position is not yet conclusive.

Fossils typical of the Flint River formation have been collected from lumps of chert or silicified limestone overlying the Ocala limestone on Flint River between Red Bluff, 7 miles above Bainbridge, Ga., and Hales Landing, 7 miles below Bainbridge. These beds were

so Cooke, C. W., Notes on the Vicksburg group: Am. Assoc. Petroleum Geologists Bull., vol. 19, no. 8, pp. 1162-1172, 1935.

67 Vaughan, T. W., unpublished notes.

49 Sloan, Earle, op. cit. (Catalogue), pp. 464-465. 
described by Vaughan ${ }^{59}$ as part of the †Chattahoochee formation. Dall ${ }^{60}$ described the fauna in 1916.

\section{MIOCENE SERIES}

\section{GENERAL FEATURES}

During early and middle Miocene time the part of the Coastal Plain that lies between the Santee River in South Carolina and the Cape Fear River in North Carolina seems to have been above water, although the present land for a considerable distance inland from the present coast both north and south of that area was submerged. This old land area, the Great Carolina Ridge of Dall ${ }^{61}$ may have projected for many miles into the Atlantic as a peninsula separating an enlarged Chesapeake embayment from an enlarged Gulf of Mexico, Florida being at that time submerged. In late Miocene time this peninsula, too, became submerged, and free water communication was established along the coast. The temporary existence of this land barrier would account for the facts that the earlier Miocene deposits of South Carolina are confined to the southern part of the State and are closely related, both in lithology and in fauna, to contemporaneous deposits of Georgia and Florida but are unlike the northern formations, and that the later Miocene deposits are less provincial.

Three formations of Miocene age are described in this report. The oldest is the Hawthorn, a formation of widespread occurrence in Florida and southern Georgia, which thins out and disappears on the south flank of the Great Carolina Ridge. The next younger is an upper Miocene formation, here named "Raysor marl", whose only known occurrence is in South Carolina south of the ridge. The youngest is the Duplin marl, a thin formation that persists as scattered patches in North Carolina, South Carolina, and Georgia. Some of the largest remnants of Duplin marl lie on the ridge. The Duplin is equivalent to the upper part of the Yorktown formation as developed around Suffolk, Va., ${ }^{62}$ and the Raysor marl is equivalent to a lower part of the Yorktown but not to the oldest Yorktown. The position of these formations in the geologic column is shown in the correlation chart below.

\footnotetext{
s9 Vaughan, T. W., in Veatch, Otto, and Stephenson, L. W., Preliminary report on the geology of the Coastal Plain of Georgia, Georgia Geol. Survey Bull. 26, pp. 329-332, 1911.

60 Dall, W. H., A contribution to the invertebrate fauna of the Oligocene beds of Flint River, Ga.; U. S. Nat. Mus. Proc., vol. 51, pp. 487-524, 1916.

1 Dall, W. H., and Harris, G. D., Correlation papers, Neocene: U. S. Geol. Survey Bull. 84, p. 182, 1882.

62 Mansfield, W. C., The Chesapeake Miocene basin of sedimentation as expressed in the new geologic map of Virginia; Washington Acad. Sci. Jour., vol. 19, p. 267, 1929.
} 
Correlation of the Miocene formations of the Atlantic States

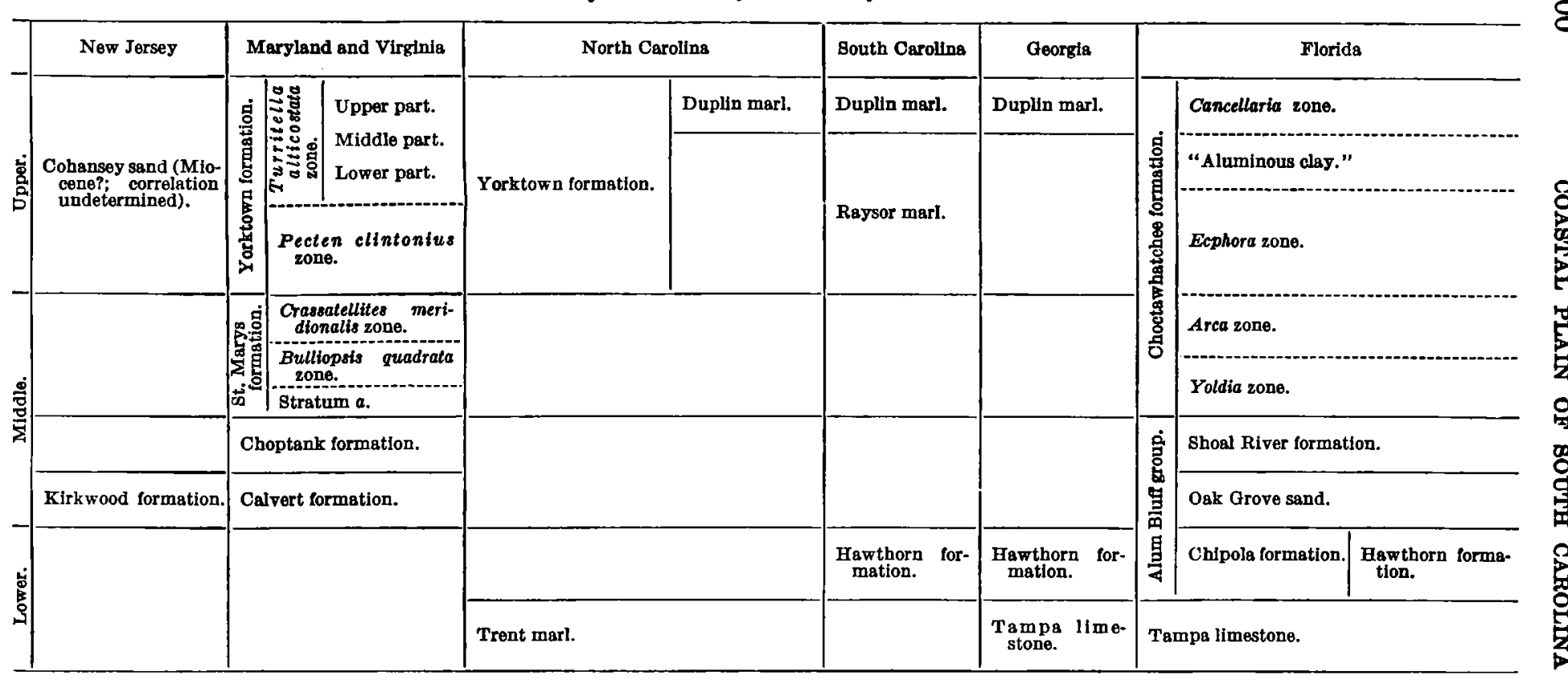




\section{HAW'THORN FORMATION}

GENERAL CHARACTBB

The Hawthorn formation was named in 1892 by Dall ${ }^{63}$ from the town of Hawthorn, in Alachua County, Fla. Its distribution and characteristics in Florida, where it is the most wide-spread formation of the Alum Bluff group, have been described by Cooke and Mossom. ${ }^{64}$ The Hawthorn in Georgia is represented by the † Marks Head marl and part of the Alum Bluff "formation" as described by Veatch and Stephenson, ${ }^{65}$ but it has not yet been formally described under the name "Hawthorn." The present paper is the first to use the name for beds in South Carolina.

Several names have been applied to the deposits in South Carolina and in the adjacent part of Georgia that are here called "Hawthorn formation." The †Combahee shale, the †Parachucla marl, the †Parachucla shale, the †Marks Head marl, part of the †Ashley marl, the $\dagger$ Edisto marl, and the $†$ Salkehatchie phase of Sloan ${ }^{86}$ are all included here in the Hawthorn formation. Although these deposits show considerable diversity and are not all contemporaneous, they can all be matched by parts of the Hawthorn formation in Florida, and their range in time is probably not greater than that of the typical Hawthorn. This grouping is not altogether new, for the †Parachucla marl and †Parachucla shale appear to have been unwittingly included in the overlying †Marks Head marl by Veatch and Stephenson, ${ }^{67}$ whose sections of the †Marks Head marl near Porters Landing, Savannah River, extend low enough to take in the †Parachucla phase.

In South Carolina the Hawthorn is separated by an erosional unconformity from every other formation upon which it has been found. It represents the deposits of an invading sea that crossed successively the Flint River formation, the Cooper marl, and the Santee limestone. It has not been discovered on formations older than the Santee, but its outlying areas may have been eroded away and left no traces.

The Hawthorn in South Carolina is nowhere deeply buried. Although recognizable natural exposures of it are rare, at most places it lies within a few feet of the surface. A few patches of younger Miocene deposits (Raysor marl and Duplin marl) have been found upon it, and elsewhere it is concealed by a thin veneer of Pleistoceno and Recent sand and clay.

The most distinctive kind of rock in the Hawthorn formation is hard, brittle shale that resembles silicified fuller's earth, but fine

${ }^{63}$ Dall, W. H., and Harris, G. D., op. cit., pp. 107-111.

G Cooke, C. W., and Mossom, Stuart, Geology of Florida: Florida Geol. Survey 20th Ann. Rept., pp. 115-137, 1929.

as Veatch, Otto, and Stephenson, L. W., Preliminary report on the geology of the Coastal Plain of Georgia: Georgia Geol. Survey Bull, 26, pp. 342-366, 1011.

- Sloan, Earle, op. cit. (Catalogue), p. 472.

of Veatch, Otto, and Stephenson, L. W., op. cit., pp. 372-373. 
sandy phosphatic marl or soft limestone is probably the most widely distributed. The phosphate rock of the coastal region, which Sloan called t"Edisto marl", is a residual product of the phosphatic limestone of the Hawthorn formation, for some of it still retains identifiable impressions of the original shells.

The Hawthorn formation is thickest in the western part of the State. The greatest thickness of which there is record is 160 feet, in a well 6 miles west of Hampton, but this may not be the maximum. The formation is very much thinner along the southern and eastern margins, and along the coast it has been eroded away entirely, with the result that marine Pleistocene clay rests directly upon the Cooper marl and abuts against the edge of the Hawthorn.

Few identifiable fossils have been found in the Hawthorn formation. The most common species that have been collected along the Savannah River are Ostrea normalis, Pecten acanikos, Carolia floridana, and Mytilus conradinus?. The first three named occur also at widely separated places in the Hawthorn formation in Florida, and the fourth is represented there by a species that is closely related if not identical. The list of fossils given below, identified by Julia Gardner, ${ }^{68}$ shows all the species that have been identified from the Hawthorn ( $\nmid$ Marks Head marl) on the Savannah River. Collections by Vaughan and Stephenson half a mile above Porters Landing contain all these species.

Turritella alcida bicarinata Gardner ms.

Natica (Cryptonatica) cf. N. (C.) platabasis Gardner ms.

Calliostoma sp. indet., ef. C. aphelium Dall

Calliostoma sp.

Scapharca staminata Dall?

Ostrea normalis Dall

Pecten acanikos Gardner.

Carolia floridana Dall

Mytilus conradinus D'Orbigny?

Astarte sp. indet.

Venericardia (Pteromeris) sp. indet., cf. V. (P.) perplana abbreviata Conrad?

Phacoides (Parvilucina) trisulcatus Conrad?

Phacoides (Parvilucina) cf. P. (P.) piluliformis Dall

Phacoides (Here) cf. P. (H.) parawhitfieldi Gardner.

Cardium sp. indet.

Dosinia ef. D. chipolana Dall.

Macrocallista sp. indet.

Strigilla n. sp.

Donax n. sp.

Mactra sp. indet.

Spisula n. sp.

Corbula n. sp.

Balanus sp.

\footnotetext{
os Gardner, Julia, The detection of the Chipola fauna in the Marks Head marl: Washington Acad. Soi. Jour., vol. 15, pp. 264-268, 1925.
} 
Recognition of the Miocene age of the †Marks Head marl was confirmed in 1910 by Vaughan, ${ }^{69}$ who placed the beds at a horizon approximately equivalent to that of the Calvert formation of Maryland, a position that seems to be a little too high. He referred the underlying shales to the Alum Bluff "formation", which at that time was regarded as Oligocene. Proof that the †Marks Head is of Chipola age (lower Alum Bluff Miocene) and that there is little difference in fauna between the †Marks Head marl and the beds that underlie it on the Savannah River was published by Julia Gardner ${ }^{70}$ in 1925.

That the marl from which the phosphate deposits near Charleston was derived (†Edisto marl) is Miocene was discovered by Dall ${ }^{71}$ in 1894, who found Miocene fossils in lumps of phosphate rock. The few fossil mollusks from the phosphate rock that are in the collections of the United States National Museum have been examined by W. C. Mansfield, who confirms Dall's reference to the Miocene and furnishes the following lists:

12017. Dump at Old Cherokee phosphate mine north of Stono River and 1 mile west of Dupont, Charleston County, S. C.; C. W. Cooke, collector, 1929:

Epitonium, n. sp.? May have come from underlying bed

Naticoid shell

Ostrea sp. May have come from underlying bed

Pecten sp.

Venericardia granulata Say

Phacoides? sp.

Antigona (Artena) undulata Conrad

Coral

12011. Old Bolton phosphate mine at Johns Island, Charleston County, S. C ; C. Wythe Cooke, collector, 1929:

Marginella sp.

Leda aff. L. flexuosa Heilprin

Pecten sp.

Venericardia granulata Say

Antigona (Artena) undulata (Conrad)

2604. Said to have come from east side of Ashley River 10 miles from Charleston, S. C.; from wreck of ship on Block Island, R. I.:

Marginella sp.

Ecphora quadricostata Say (upper spirals weaker than usual)

Ostrea sp.

Venericardia granulata Say

Phacoides cf. P. contractus Say

Cardium sp.

Anomalocardia? sp.

Antigona (Artena) undulata Conrad

3597. Ninemile Run near Tenmile Hill, 9 miles from Charleston, S. C.; from bed of gravel and bones in cut on railroad just south of stream; Frank Burns collector:

Same fauna as at station 2604.

60 Vaughan, T. W., The Miocene horizons at Porters Landing, Ga.: Science, vol. 31, pp. 833-834, 1910. ${ }^{70}$ Gardner, Julia, op. cit.

71 Dall, W. H., Notes on the Miocene and Pliocene of Gay Head, Marthas Vineyard, Mass., and on the "land phosphate" of the Ashley River district, S. C.: Am. Jour. Sci., 3d ser., vol. 48, pp. 300-301, 1894. 
3929. Upper edge of phosphate deposit, Ashley River, near Charleston, S. C.; Earle Sloan, collector, 1904:

Turritella ef. T. tampae Heilprin

Pecten sp.

Cardium aff. C. taphrium Dall

Glycymeris sp.

The presence of a Turritella close to $T$. tampae, a species known elsewhere only from the lower Miocene Tampa limestone of Florida, and a Cardium related to C. taphrium, also found at Tampa but ranging up into the Shoal River formation at the top of the Alum Bluff group (middle and lower Miocene) of Florida, indicates that the rock at station 3929 probably came from a horizon well down in the Miocene; but Ecphora quadricostata, Venericardia granulata, and a Phacoides resembling $P$. contractus at two or all of stations 12011,12017 , 2604 , and 3597, appear to indicate that the rock at those places does not belong to the lower Miocene. Station 3929 may represent a different horizon from that at the other localities.

Although the fossils that have been collected from the †Edisto marl show conclusively that the rock is Miocene (not Eocene, as some earlier workers supposed), they are insufficient to establish its exact stratigraphic position within the Miocene. They appear to indicate that the rock is older than the Duplin marl and probably older than the Raysor marl, a local formation, known only at Raysor Bridge, S. C. This seems to place the rock within the time limits of the Hawthorn formation of Florida. Moreover, the facts that the Hawthorn formation elsewhere includes much phosphatic marl or limestone similar to the $†$ Edisto and that it is the source from which the great phosphate deposits of Florida have been derived ${ }^{72}$ greatly strengthen the somewhat dubious evidence of the fossils that the parent rock of the South Carolina phosphates belongs to the Hawthorn formation.

The Hawthorn formation covers most of the southern part of South Carolina. The northern boundary passes from Allendale County in a general easterly direction to the neighborhood of the mouths of the Santee. The formation has so few exposures that its boundaries are in many places uncertain, and no high degree of accuracy is claimed for the limit shown on plate 2, although it is believed that most of the area so indicated is underlain by the Hawthorn.

\section{SAVANNAE RIVER}

In its course across the Hawthorn formation the Savannah River flows against a bluff from a point about a mile above Hudsons Ferry Landing (192), Screven County, Ga., 2 miles above the Effingham County line, most of the way to Ebenezer Landing, about 35 miles by water below. In this bluff on the Georgia side are many exposures of the Hawthorn formation (pl. 16, B); but on the South Carolina side

" Cooke, C. W., and Mossom, Stuart, op. cit., p. 175. 
the banks, for the most part, are low and swampy, and the only outcrop of the Hawthorn that has been reported is at Purysburg (200), 11 miles below Ebenezer Landing and 1 mile north of the latitude of Hardeeville. The description that follows is based chiefly on Veatch and Stephenson's report on the geology of the Coastal Plain of Georgia. ${ }^{73}$

Hudsons Ferry Landing (192).-About 300 yards upstream from the boat landing at Hudsons Ferry and 25 feet above water level, a bed of compact sand and fine-grained clay containing prints of fossils is probably referable to the Hawthorn formation. Lower beds, exposed at the base of the bluff near the landing, are as follows:

\section{Section of Hawthorn formation at base of bluff near Hudsons Ferry Landing}

3. Pale-green calcareous clay containing indistinct impressions Inches of leaves. . . .

2. Hard sandy claystone containing poor prints of fossils..... 3

1. Dark-green coarse sand, argillaceous and compact; poor prints of fossils; to water's edge............ 12

The bluff half a mile below Hudsons Ferry Landing shows the following section:

Section in west bluff of Savannah River half a mile below Hudsons Ferry Landing

Wicomico (?) formation (Pleistocene?): Feet

7. Gray surficial sand

6. Coarse sand containing a small amount of clay, mottled red and gray; thin line of quartz pebbles at base .... 30

Hawthorn (?) formation (Miocene):

5. Brown fine sand. .......... 7

4. Yellow and gray unconsolidated sand; thin line of flat, 20 discoidal pebbles at base....................... 20

Hawthorn formation (Lower Miocene):

3. Light-greenish sandy clay, faintly laminated........ 6

2. Greenish-gray or ash-colored compact sand.......... 11

1. Red and brown compact sand...... 4

Section at a landing three-quarters of a mile below Hudsons Ferry Landing

Wicomico formation (Pleistocene): Feet

8. Loose gray sand............... 2

7. Mottled gray and red coarse clayey sand . ......... 10

6. Interstratified harsh sand and fine-grained waxy clay - 10

5. Brown ocherous coarse sand; well-rounded pebbles at

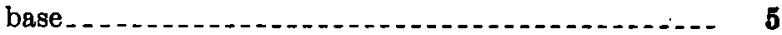

Hawthorn formation (Lower Miocene):

4. Compact ash-colored argillaceous sand............. 10

3. Drab, brown, or yellow sandy clay containing poorly preserved fossils; Pecten "madisonius" (perhaps $P$.

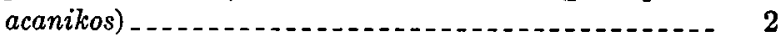

2. Massive gray and brown phosphatic sand.......... 25

1. Concealed by creep from upper part of bluff ....... 20

7 Veatch, Otto, and Stephenson, L. W., op. cit., pp. 361-362, 370-376. 
Bed 3 contains, besides Pecten, poorly preserved leaves, shark teeth, dental plates of fish, and, at the bottom, a few round quartz pebbles. Veatch and Stephenson doubtfully referred it to the Duplin marl.

Marks Head (193).- The following section, which was measured at the type locality of the TMarks Head marl, near the head of Marks Head Run, 1 mile northwest of Porters Landing, Effingham County, Ga., is adapted from the unpublished notes of $\mathrm{T}$. W. Vaughan, December 2, 1907, who visited the place with Earle Sloan:

Section on Marks Head Run

Duplin(?) marl (Miocene):

4. Fragments of hard gray marl.

Hawthorn formation (lower Miocene):

3. Yellowish-brown argillaceous fossiliferous marl over- Fee lying partly indurated calcareous sand containing a few casts of fossils. . . . . . . .

2. Blue-green soft marl with small rounded black particles and numerous rotten shells; fossils collected....... 4

1. Hard brown sandy marl containing many rotten shells, apparently similar to those in bed above.......... 1

Beds Jower than those on Marks Head Run were examined by Sloan and Vaughan at Marl Lake (probably a cut-off of the Savannah River), $1 \frac{112}{2}$ miles northwest of Porters Landing. The following section also is adapted from Vaughan's notes:

\section{Section of Hawthorn formation at Marl Lake}

4. Laminated drab, yellow, and gray shale ( $†$ Parachucla shale)

3. Layer of pebbles over brown and yellow sand which also contains pebbles.

2. Yellow fossiliferous marl (Carolia-bearing bed) containing quartz pebbles ranging from pea size to half an inch in diameter, a few as much as 1 inch (†Parachucla marl); fossils collected

1. Arenaceous gray shale with numerous red splotches (†Combahee shale); a few Lucina casts; exposed only at very low water.

Porters Landing (194).-Both the Duplin marl and the Hawthorn formation are exposed in the bluff at Porters Landing, 62 miles above Savannah. The Duplin here was referred by Sloan ${ }^{74}$ to his $\dagger$ Edisto phase, which in this report is put in the Hawthorn formation, but Vaughan ${ }^{76}$ showed that the fossils at this place are younger and are of Duplin age. The following section, by Sloan and Vaughan, is adapted from Vaughan's unpublished notes of December 2, 1907.

" Sloan, Earle, op. cit. (Catalogue), p. 273.

7 Vaughan, T, W., The Miocene horizons at Porters Landing, Ga.: Science, vol. 31, pp. 833-834, 1910. 


\section{Section at Porters Landing}

Sunderland(?) formation (Pleistocene?):

Feet

8. Clay and stratified sand of various colors and sizes of grain . . .

Duplin marl (upper Miocene):

7. Thin broken line of vertebrate fossils (shark teeth and dental plates of Myliobatis) and particles of phosphate rock.

6. Hard yellow to gray marl forming a ledge; many fossils, including Ecphora sp., Ostrea disparilis Pecten eboreus, and many Anomia sp...............

Hawthorn formation (lower Miocene):

5. Yellow arenaceous material in which occur nodular masses composed of sand indurated by calcareous cement; at the bottom is an undulating ledge of indurated material similar to the concretions and containing Ostrea normalis Dall. (Leached †Marks

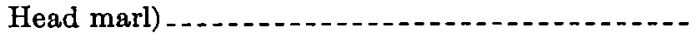

4. Loose yellow sand containing many Pecten acanikos Gardner, also Mytilus conradinus? and Balanus sp. . . . . . . . . . .

3. Drab shale with siliceous concretions (†Parachucla shale)

2. Carolia floridana bed, calcareous constituents largely leached (†Parachucla marl); exposed at low water _ 0-5

1. Arenaceous laminated gray shale with sandy partings (†Combahee shale)

The following section is adapted from Veatch and Stephenson: $:^{76}$

\section{Section 100 yards below Porters Landing}

Sunderland(?) formation (Pleistocene?):

6. Loose gray sand

5. White, yellow, and red sand

Duplin marl (upper Miocene):

4. Bed of shell marl, shells in a matrix of coarse phosphatic sand; small, well-rounded quartz pebbles at the baise, resting unconformably on bed 3; contains Pecten eboreus, $P$. jeffersonius, Anomia simplex,

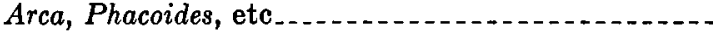

Hawthorn formation (lower Miocene):

3. Brown or gray phosphatic sand with large calcareous nodules as much as 2 feet in diameter or length....

2. Drab or dark-greenish, faintly laminated sandy clay --

1. Drab sandy clay, partly silicified; contains hard, round siliceous concretions; phosphate not so abundant as in bed 3; contains Pecten acanikos..............

At low water about 2 feet of fine compact gray sand is exposed at the base of the bluff at Porters Landing. A few pebbles near the top of the sand bed may have fallen down borings in the.surface. Above

is Veatch, Otto, and Stephenson, L. W., op. cit., p. 372.

$143491-36-8$ 
the sand is dark-gray sandy clay containing coarse sand and at its base many small discoidal pebbles.

The round concretions in the Hawthorn formation at Porters Landing are composed throughout of radiating calcareous crystals, apparently calcite, like great spherulites. ${ }^{77}$

Mount Pleasant Landing (195).--Both the Duplin marl and the $\dagger$ Marks Head marl are exposed at Mount Pleasant Landing, 11/2 miles below Porters Landing, according to Veatch and Stephenson, ${ }^{78}$ whose section, slightly modified, is as follows:

\section{Section at Mount Pleasant Landing}

Sunderland(?) formation (Pleistocene?):

Feet

5. Sand and white tough, waxy, laminated clay with sand partings; poorly exposed..................... 20

4. Coarse brown sand . .

Duplin marl (upper Miocene):

3. Friable marl and limestone; contains shells and casts

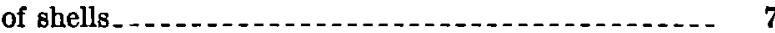

Hawthorn formation (lower Miocene):

2. Brownish phosphatic sand _........... 25

1. Greenish sandy clay, not well exposed.......... 20

Seaboard Air Line Railway bridge south of Garnett (196).- -Veatch and Stephenson ${ }^{78}$ report 30 feet of fine-grained white and yellow sugarlike sand containing brown phosphatic grains in the lower part at the railway bridge 3 miles north of Clyo, Ga. It probably forms part of the Hawthorn formation.

Sisters Ferry (197).-At Sisters Ferry, 2 miles southeast of the Seaboard Air Line Railway bridge, Veatch and Stephenson ${ }^{78}$ report the following sequence:

\section{Section at Sisters Ferry, Savannah River}

Wicomico(?) formation (Pleistocene):

11. Thin covering of gray sand at top of bluff. Feet

10. Mottled red and yellow sand with some thin clay layers. ............. 20

9. Coarse cross-bedded yellow, red, and white sand...- 20

8. Poorly exposed..... 10

Hawthorn formation (lower Miocene):

7. Drab laminated clay; contains hard sandy calcareous nodules covered with a crust of fibrous calcite_... 7

6. Hard silicified clay ...... $3 / 4$

5. Drab clay . .

4. Hard silicifed clay ............ $1 / 4$

3. Laminated gray very sandy clay ............. $2 \frac{1}{2}$

2. Hard silicified clay .......................... 2

1. Very sandy clay; contains some black phosphatic

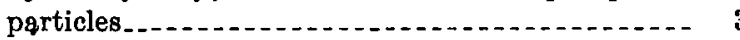

" Cooke, C. W., Radial calcite concretions in marine beds in Georgia: Washington Acad. Sci. Jour., vol. 21, p. 27, 1931.

73 Veatch, Otto, and Stephenson, L. W., op. cit., p. 374. 
Grayish sandy clay like that at Sisters Ferry is reported in the lower 8 feet of the bluff at Frying Pan Landing (198), 8 miles below Sisters Ferry. At Ebenezer Landing (199), 5 miles below Frying Pan Landing and 34 miles above Savannah, brownish or yellow compact sandy clay, containing poor prints and casts of fossils, and white and brownish fine quartz sand are regarded by Veatch and Stephenson ${ }^{79}$ as Miocene (Hawthorn formation).

Purysburg (200).-A low bluff on the Savannah River at Purysburg, 3 miles northwest of Hardeeville, is described by Veatch and Stephenson ${ }^{80}$ as follows:

\section{Section at Purysburg, 28 miles above Savannah}

Pleistocene:

Feet

6. Red sandy clay containing small pebbles; color due to

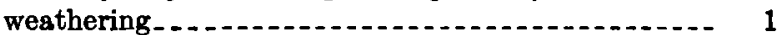

5. Drab or white laminated clay

4. Line of coarse quartz pebbles......... $1 / 4$

Miocene (?):

3. Gray or pale-green argillaceous sand........... 3y/2

2. Thin line of quartz pebbles........

Unconformity.

1. Gray or pale-green argillaceous sand ............

Dukes (201).-At Dukes siding, on the Seaboard Air Line Railway 41/4 miles south of Fairfax, an old dug well, now filled, penetrated the Hawthorn formation. Lumps of rock that evidently came out of the well consist of firm gray or brown sandy marl containing minute phosphatic grains and hard silicified shell marl. A lump of the shell marl yielded the fossils in the following list:

10409. Old well at Dukes siding, $23 / 4$ miles north of Gifford; C. W. Cooke, collector, April 12, 1922; identified by W. C. Mansfield:

Terebra aff. T. tantula Conrad

"Drillia" aff. D. lapenotieri Dall

Marginella sp.

Latirus? sp.

Ficus sp.

Turritella cf. T. alcida Dall

Turritella sp.

Architectonica sp.

Calyptraea? sp.

Sinum cf. S. chipolanum Dall

Liotia sp.

Fissuridea sp.

Dentalium sp.

Glycymeris cf. G. lamyi Dall
Glycymeris sp.

Arca sp.

Pecten sp., type of P. acanikos Gardner Venericardia? aff. V. granulata Say

Venericardia n. sp.? aff. V. perplana Say Phacoides sp.

Cardium sp.

Antigona? sp.

Corbula sp.

Corbula? sp.

Spisula sp.

Teredo sp.

Echinoid.

These fossils, though not well preserved, indicate a fauna of rather warm water, probably of Chipola age.

7 Veatch, Otto, and Stephenson, L. W., op. cit., p. 375.

so Idem, p. 376. 
Gifford.-Sloan ${ }^{81}$ observed the following section in a well at Gifford station:

\section{Section in well at Gifford}

[Adapted from Sloan]

3. Firm mottled red and white clay

2. Dark gray-green granular glauconitic phosphatic marl, containing shark teeth and Myliobatis? sp _. _............. 3-8

1. Hard, silicified marl underlain by water-bearing sand.... 11

Lightsey place, 6 miles west of Hampton.-A well drilled in 1905 by M. J. Jennings on the P. W. Lightsey place, 6 miles west of Hampton, passed through fine light-gray sand, apparently slightly phosphatic, between the depths of 75 and 145 feet. From 145 to 160 feet the drill was in hard gray calcareous sandstone, also phosphatic, and at 160 feet it passed out of the Hawthorn formation into soft brownish-gray Cooper marl.

Fechtig (202).-The following log of W. F. Cunningham's well at Fechtig, drilled by G. H. Jennings in 1906, indicates that the Hawthorn(?) formation is about 100 feet thick in that vicinity.

\section{Log of W. F. Cunningham's well at Fechtig}

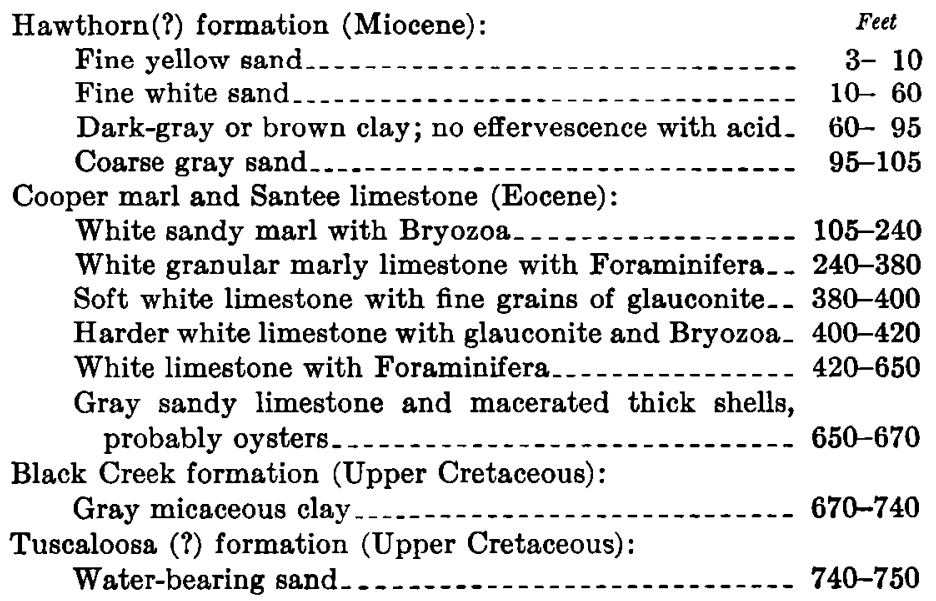

JASPER COUNTY

Dawsons Landing (203).--According to Sloan ${ }^{82}$ stratified †Parachucla shale is exposed in the bed and banks of the Coosawhatchie River to a height of 9 feet above low tide at Dawsons Landing, 23/2 miles south of Coosawhatchie station. It consists of alternate hard and soft layers, brown in the middle but grading through yellow to white on the surface. 
Huspa Creek (204).-Hard, brittle shale, apparently silicified diatomaceous earth, crops out at high-tide level on Huspa Creek 1.2 miles west of Gardens Corner and about the same distance east of Sheldon. The occurrence was first noted by Tuomey ${ }^{83}$ and has since been described by Sloan. ${ }^{84}$ The rock appears to have been originally pale greenish gray, but much of it is now stained various shades of brown. Some of it shows slickensided surfaces, as if it had been subjected to strains while still semiplastic. Sloan says that it extends to low-tide level and is composed of alternate hard and soft layers and includes pockets of glauconite. Similar rock occurs in the Hawthorn formation at several places in Georgia and on the Suwannee River near the Georgia-Florida line. Sloan refers the rock on Huspa Creek to the †Parachucla shale.

Pocotaligo (205).- - Hard shale like that on Huspa Creek is underlain by green hackly clay on State Highway 28,2 miles southeast of Pocotaligo and 21/2 miles northwest of Sheldon. There appears to be little difference between the beds except hardness. Not more than 5 feet is exposed.

Chisolms Island.-The phosphate deposits on Chisolms Island and elsewhere in the vicinity of Beaufort were probably derived from the Hawthorn formation, but the few remnants of the Hawthorn are very thin. A deep well of the Charleston Mining \& Manufacturing Co., 7 miles northeast of Beaufort (probably at Chisolm) passed through 6 feet of gray argillaceous sand weathering orange-red, underlain by $1 \frac{1}{2}$ feet of fine yellow micaceous sand containing a few black grains. These may be of Pleistocene age. Cuttings indicate that the drill entered the Cooper marl at a depth of $7 \frac{12}{1}$ feet, but the driller's log records green mud from $7 \frac{1}{2}$ to 47 feet, below which hard limestone was struck. At Frogmore, St. Helena Island, the Hawthorn appears to have been entirely eroded, marine Pleistocene beds being deposited directly on the Cooper marl.

\section{COLLETON COUNTY}

Salkehatchie River.-According to Sloan, ${ }^{85}$ the bed of the Salkehatchie River from a point above Broxton Ford, 3/2 miles northwest of Miley, to the mouth of the Little Salkehatchie River is composed of shale similar to that exposed at low water at Porters Landing, Savannah River. The more prominent exposures are at Broxton Ford (206) and at Tobys Bluff (207), which is just above the mouth

83 Tuomey, Michael, op. cit., p. 152.

${ }^{84}$ Sloan, Earle, op. cit. (Catalogue), p. 345.

iks Idem, pp. 327-328. 
of Whippy Swamp. The following is Sloan's section at Broxton Ford:

West side of river:

\section{Section at Broxton Ford}

5. Fine sand (at top), ash-gray casehardened clay and gritty white and red mottled clay (at base) .........

4. Yellow-red fine-grained, compact argillaceous sand; the mass is firm and weathers to rounded surfaces.-

East side of river:

3. Stratified yellow-red medium-coarse sand, partly induratted

Freat

2. Indurated clay sand, cemented hard by iron oxide resulting from decomposition of glauconite, which appears in irregularly distributed pockets and splotches -

1. Fine-grained clay shale of pale ash-blue color, enclosing fine sand, coarse sand, rounded pebbles, and a few pockets of glauconite (†Combahee phase); also contains numerous fossil casts

\section{Sloan says:}

Along the flats bordering the Salkehatchie River on the east a glauconite bed about 5 feet thick is exposed by wells, overlying the probable equivalent of the fossiliferous shale exhibited at Broxton Ford. The glauconitic material is of the same character as that exposed at Gifford ("Salkehatchie phase").

Sloan ${ }^{86}$ also reports a glauconitic bed between 4 and 5 feet thick in a well at Carter's mill, near the Atlantic Coast Line Railroad bridge over the Little Salkehatchie River west of Williams.

Edisto River.-Sloan catalogs the †Combahee shale (Hawthorn formation) from the Edisto River, 1 mile south of Raysor Bridge (208). He says: ${ }^{87}$

The west bank exhibits a bluff with mottled clays, overlying about 12 feet of laminated pale-drab clay, which rests on a thin undulating seam of oyster shells and fragments of bones. Unconformably underlying the above there is observed, varying from 1.7 feet to 3.1 feet above and extending 1.2 feet below the zero water level, a bed of dark laminated shale (Oligocene-Combahee) overlying the typical glauconitic marl of the Edisto River.

Sloan ${ }^{88}$ lists the †Parachucla shale (Hawthorn formation) from Beech Bank(171), on the west side of the Edisto River 0.7 mile above Parkers Ferry, which is 7 miles (direct) above Jacksonboro. It is said to overlie unconformably the yellow-white Eocene Cooper marl and to be covered by an irregular layer of mixed phosphate pebbles and quartz cobbles and 1 foot of laminated clay.

Tough marl, almost as hard as limestone at some places, is said by Sloan ${ }^{89}$ to extend to a depth of 2 feet below low-water mark in the Edisto River at a small island called "The Dividers" (209), 2 miles.

\footnotetext{
B6 Sloan, Earle, op. cit. (Catalogue), p. 328.

${ }^{87}$ Idem, p. 327.

88 Idem, p. 284

so Idem, p. 378.
} 
above the railway bridge at Ponpon. The marl was referred by Sloan to his †Edisto phase, which is here treated as part of the Hawthorn formation. Sloan ${ }^{80}$ also reports a very thin surficial deposit of shale on the west bank of the Edisto River at Ponpon.

DORCHESTER COUNTY

Griggs Landing (210).-According to Sloan, ${ }^{01}$ the upper limit of workable phosphate deposits lies at Griggs Landing, on the southwest side of the Ashley River 4.7 miles S. $27^{\circ} \mathrm{W}$. of Ladson. At this place the $†$ Edisto marl (Hawthorn formation) has not been so completely phosphatized as farther seaward.

Ashley marl works (211). - The old pit at the Ashley marl works, $5 \frac{1}{4}$ miles west of Tenmile and 9 miles south of Ladson, afforded an interesting section, which was described by Sloan ${ }^{22}$ as follows:

Miocene (Edisto phase) on Eocene(?) (Ashley phase). The surface of the ground at this point is about 8 feet above mean low tide. The quarry affords the following exposure:

(a) 3.0 feet of loam.

(b) 0.5 feet of phosphate rock embedded in a dark aluminous matrix.

(c) 2.5 feet of a mucky aluminous mass, containing: Lime, 6.10 percent; magnesia, 0.20 percent; alumina, 7.11 percent; ferric oxide, 2.36 percent; carbonic acid, 1.60 percent; phosphoric acid $\left(\mathrm{P}_{2} \mathrm{O}_{6}\right), 3.66$ percent; silica (and insoluble), 73.13 percent; ignition, 2.96 percent; total, 99.87 percent. Equivalents: Calcium carbonate, 3.14 percent; tricalcium phosphate, 8.00 percent; magnesium carbonate, 0.42 percent.

(d) 10.0 feet of dark-green drab marl, enclosing scattered fine rounded particles of phosphatic matter (but with no observable fossils); rubs grainy, with slight plasticity when wet. Analysis: Lime, 48.80 percent; alumina, 1.11 percent; ferric oxide, 0.95 percent; carbonic acid $\left(\mathrm{CO}_{2}\right), 34.50$ percent; phosphoric acid $\left(\mathrm{P}_{2} \mathrm{O}_{5}\right), 4.13$ percent; silica (and insoluble), 8.56 percent; ignition, 0.62 percent; moisture, 1.19 percent; total, 99.86 percent. Equivalents: Calcium carbonate, 78.41 percent; tricalcium phosphate, 9.02 percent.

(e) 18.0 feet of marl physically similar to overlying marl excepting in content of smaller quantity of microscopic particles of phosphate rock. Analysis: Lime, 43.41 percent; magnesia, 0.31 percent; alumina, 1.88 percent; ferric oxide, 0.95 percent; carbonic acid $\left(\mathrm{CO}_{2}\right), 32.79$ percent; phosphoric acid $\left(\mathrm{P}_{2} \mathrm{O}_{5}\right), 1.76$ percent; silica (and insoluble), 15.45 percent; ignition, 1.68 percent; moisture, 1.29 percent; total, 99.52 percent. Equivalents: Calcium carbonate, 73.77 percent; tricalcium phosphate, 3.85 percent; magnesium carbonate, 0.65 percent.

$(f)$ Broken layer of rounded quartz pebbles less than $2 \frac{1}{2}$ inches in diameter, perhaps separating the Ashley from the Cooper marl.

(g) 22.0 feet of light-gray smooth plastic marl. Analysis: Lime, 41.80 percent; magnesia, 1.20 percent; alumina, 2.74 percent; ferric oxide, 1.10 percent; carbonic acid $\left(\mathrm{CO}_{2}\right), 33.74$ percent; phosphoric acid $\left(\mathrm{P}_{2} \mathrm{O}_{5}\right), 0.45$ percent; silica (and insoluble), 15.61 percent; ignition, 1.31 percent; moisture, 2.46 percent; total, 100.41 percent. Equivalents: Calcium carbonate, 73.70 percent; tricalcium phosphate, 0.98 percent; magnesium carbonate, 2.51 percent.

(h) 15.5 feet of smooth gray marl. Analysis: Lime, 44.84 percent; magnesia, 1.29 percent; alumina, 2.20 percent; ferric oxide, 0.63 percent; carbonic acid

oo Sloan, Earle, op. cit. (Catalogue), p. 345.

11 Idem, p. 287.

92 Idem, pp. 287-289. 
$\left(\mathrm{CO}_{2}\right), 36.49$ percent; phosphoric acid $\left(\mathrm{P}_{2} \mathrm{O}_{5}\right), 0.16$ percent; silica (and insoluble), 11.69 percent; ignition, 0.95 percent; moisture, 1.58 percent; total, 99.83 percent. Equivalents: Calcium carbonate, 79.73 percent; tricalcium phosphate, 0.35 percent; magnesium carbonate, 2.70 percent. This stratum was quarried to a depth of 80 feet (mean low tide), where, it is reported, a layer of loose shells occurred.

This section may be restated as follows:

Section at Ashley marl works

Pleistocene or Recent:

Feet

7. Loam

Miocene (residual Hawthorn formation; †Edisto marl of Sloan):

6. Phosphate rock embedded in dark clay ......... . 5

5. Mucky clay, probably residual._............. 2. 5

Miocene (?) (Hawthorn (?) formation; †Ashley marl of Sloan):

4. Dark-green or drab marl containing scattered grains of phosphate; no fossils seen; rubs grainy; slightly plastic when wet

3. Like bed 4 but containing fewer phosphate grains; quartz pebbles as much as $2 \frac{1}{2}$ inches in diameter at base

Eocene (Cooper marl):

2. Light-gray smooth, plastic marl

1. Smooth gray marl

The presence of a pebble layer at the base of bed 3 (stratum $f$ of Sloan's section) seems a good reason for separating the $\dagger$ Ashley marl at this place from the Cooper marl. The †Ashley marl, beds 3 and 4, may be the parent rock from which the phosphate rock and clay (beds 5 and 6) were derived, and, if so, it is the unaltered Hawthorn formation. Its description tallies well with the phosphatic limestone of the Hawthorn formation in Florida.

Captains Creek (212).-According to Sloan,,$^{93}$ a seam of fossiliferous glauconitic and phosphatic clay marl lies 3 feet below the surface in the swamp of Captains Creek, 1.8 miles S. $25^{\circ} \mathrm{W}$. of Ridgeville. It contains 17 percent of calcium phosphate. It is underlain by the Cooper marl. Sloan referred it to his †Salkehatchie phase; it is probably part of the Hawthorn formation.

\section{CHARLESTON COUNTY}

Ponpon (213).-Ditches along United States Highway 17, 1 mile east of Ponpon, show white concretions containing much very fine sand. It doubtless forms part of the Hawthorn formation.

Lambs (175).-At Lambs, east of the Ashley River and less than half a mile south of the Berkeley County line, the †Edisto marl lies 4 feet below the surface. It consists of $2 \frac{1}{2}$ feet of fine gray sandy marl containing inclusions of harder white marl and many irregular phos-

o3 Sloan, Earle, op. cit. (Catalogue), p. 285. 
phatic nodules and shark teeth. It unconformably overlies the Eocene Cooper marl. A section at the marl pit of the Charleston Mining \& Manufacturing Co. at Lambs is given in the description of the Cooper marl on page 87.

Runnymede (214).-According to Sloan ${ }^{94}$ his $\dagger$ Edisto marl overlies the Cooper at Runnymede, west of Lambs.

Magnolia Gardens (176).-A ledge of hard cavernous limestone that overlies phosphatic Cooper (?) marl just above the tramway bridge over the Ashley River near Magnolia Gardens and 21/2 miles northwest of Drayton probably represents the Hawthorn formation, although it may be a harder part of the Cooper marl. On the surface of the ground and in cavities in the limestone are many rounded lumps of phosphate rock that range from small grains to lumps several inches in diameter. Phosphate rock has been mined at many places both north and south of the Ashley in this vicinity.

Drayton (Bees Ferry) (177).-There are poor exposures of the residual Hawthorn marl on the Ashley River beneath the Atlantic Coast Line Railroad bridge at Drayton. Sloan ${ }^{95}$ reports that at low tide 4 $\frac{1}{2}$ feet of $\dagger$ Ashley (Cooper) marl was exposed, 1.3 feet of phosphate rock in a mucky matrix, and 3 feet of soil. Bees Ferry has long been noted for the profusion of fish teeth found there.

Johns Island (215).- The old Bolton phosphate mine at Johns Island is now badly overgrown and the section obscured, but a few loose lumps of phosphatic limestone yielded casts of the shells listed from station 12011 (p. 103). A section at the mine is given on page 151. Sloan says: ${ }^{: 6}$

The phosphate rock is not of concretionary structure but consists of a bed of phosphatized marl, invaded by a stiff dark calcareous mud enclosing rounded pebbles of phosphate rock and quartz and the fossil remains of many vertebrates. The phosphatized mass is extremely irregular and even jagged in outline and in many instances is honeycombed with irregular spaces; the phosphate rock is distinctly characterized by the almost uniform inclusion of casts and molds of the original Miocene marl, vertebrate remains being very rarely included, although freely existing in the mud matrix.

\section{RAYSOR MARL}

DEFINITION

The name "Raysor marl" is here proposed for deposits of upper Miocene age older than the Duplin marl in South Carolina. The name is taken from Raysor Bridge on the Edisto River 8 miles southwest of St. George, near which the only known outcrops of the formation occur.

The Raysor marl is believed to be equivalent to a middle part of the Yorktown formation of Virginia and North Carolina and to the 
Ecphora zone of the Choctawhatchee formation of Florida. (See table on p. 100.)

\section{COLLETON COUNTY}

Raysor Bridge (216).-The only known outcrops of the Raysor marl are near Raysor Bridge on the Edisto River, 8 miles southwest of St. George. The following section, which is adapted from Sloan, ${ }^{97}$ was measured on the west bank about 1,200 feet below the bridge. Sloan ${ }^{98}$ referred the Miocene beds to his $\dagger$ Upper Pee Dee phase, and the Eocene marl to his $†$ Warley Hill phase.

\section{Section on Edisto River 1,200 feet below Raysor Bridge}

Wicomico formation (Pleistocene):

5. Mottled clay and sand.

4. Dun-colored clay in layers, horizontally interstratified with thin seams of sand . ....................... 11

3. Coarse sand on the much-eroded surface of the Raysor

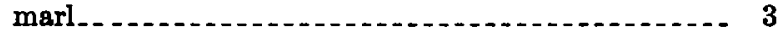

Raysor marl (upper Miocene):

2. Marl consisting of shells in a dark-blue soft matrix; contains 80.82 percent of calcium carbonate............. 314

Cooper marl (Eocene):

1. Harsh, hard glauconitic marl similar to marl at Stokes Bridge. . . . . . . .

The mollusks found in the Raysor marl near Raysor Bridge have been studied by W. C. Mansfield, and the recognition of their age is due to him. The species identified are shown in the following list:

5295. Raysor Bridge, Earle Sloan, collector, and 3991, 1 mile below Raysor Bridge, on road from St. George station to courthouse, Earle Sloan and Frank Burns, collectors:

Paracyathus vaughani Gave; identified by T. W. Vaughan

Epitonium sp.

Turritella variabilis Conrad

Fissuridea cattilliformis (Rogers)

Cadulus thallus (Conrad)

Nucula proxima Say

Leda trochilia Dall (like form in Ecphora zone of Choctawhatchee formation)

Yoldia tarphaeia Dall (like form in Ecphora zone of Choctawhatchee formation)

Glycymeris subovata (Say) var.

Arca (Scapharca) lienosa (Say)

Ostrea sp.

Ostrea disparilis Conrad

Pecten jeffersonius Say

Pecten jeffersonius var. aff. P. jeffersonius edgecombensis Conrad

Plicatula marginata Say

Crassatellites gibbesii Tuomey and Holmes

Crassatellites undulatus cyclopterus Dall

Astarte concentrica var. bella Conrad

Astarte floridana Dall (Ecphora zone)

n Sloan, Earle, op. cit. (Catalogue), pp. 280-281.

99 Idem, p. 474. 
Cardita (Carditamera) arata (Conrad)

Venericardia granulata Say

Chama corticosa Conrad

Echinochama arcinella (Linnaeus)

Phacoides cribrarius (Say)

Phacoides contractus (Say)

Phacoides crenulatus Conrad

Phacoides radians (Conrad)

Diplodonta nucleiformis (Wagner)

Diplodonta yorkensis Dall?

Divaricella quadrisulcata D'Obigny

Aligena aequata (Conrad)

Cardium sp.

Isocardia fraterna Say, grading toward I. carolina Dall

Chione latilirata athleta Conrad

Tellina (Merisca) aequistriata Say

Tellina (Angulus) declivis Conrad

Semele subovata (Say) var.

Corbula inaequalis Say

Corbula, group of C. chipolana Dall

Saxicava sp.

Teredo calamus H. C. Lea

DUPLIN MARL

GENERAL CharaCter

The deposits here called Duplin marl were casually mentioned by Tuomey ${ }^{80}$ in 1848, as the "TSumter beds" and the "bed in Sumter", but in his later work on the fossils ${ }^{1}$ they were called simply "Pleiocene." In the first (1863), second (1875), and third (1880) editions of Dana's "Manual of geology" they were referred to the †Sumter epoch, which included all the so-called "Pliocene" of the Carolinas, but in the fourth edition (1895) they were grouped with the Miocene of the Chesapeake region, and the name "Sumter" was omitted.

The first use of the name "Duplin" (from Duplin County, N. C.) appears to be that of Dall, ${ }^{2}$ who, in 1896, stated that a fossil shell came from the Duplin beds at Natural Well, N. C. The name later appeared in his correlation table, ${ }^{3}$ where the beds were classified as late Miocene, and the name has since been commonly accepted. The distribution and characteristics of the formation in North Carolina have been described in detail by Miller ${ }^{4}$; those in Georgia by

"T Tuomey, Michael, op. cit., p. 178.

1 Tuomey, Michsel, and Holmes, F. S., Pleiocene fossils of South Carolina, 152 pp., Charleston 8. C., 1857.

2 Dall, W. H., Diagnoses of new Tertiary fossils from the southern United States: U. B. Nat. Mus. Proc., vol. 18, p. $40,1896$.

- Dall, W. H., A table of North A merican Tertiary horizons: U. S. Geol. Survey 18th Ann. Rept., pt. 2, p. 338, 1898.

4Miller, B. L., North Carolina Geol. and Econ. Survey, vol. 3, pp. 236-249, 1912. 
Veatch and Stephenson. ${ }^{5}$ Most of the known occurrences of the Duplin marl in South Carolina were included by Sloan $^{6}$ in his $\nmid \mathrm{Peo}$ Dee phase, but that name is not acceptable because it is applied to the Peedee formation, of Upper Cretaceous age.

In South Carolina the Duplin consists chiefly of shell marl. It rests upon the eroded surface of formations that range in age from basal Upper Cretaceous to lower Miocene, and therefore it represents the deposits formed during a temporary invasion of the sea across a former land surface (pl. 16, $B$ ). When first laid down it probably made a continuous sheet of marl across the State from the North Carolina line to Georgia and from the seashore inland about 80 miles to the edge of the hills; but most of this vast sheet has been washed away, and the few remaining patches are almost completely covered by Pleistocene terrace deposits. Natural exposures of the formation are very rare and are confined to bluffs along the principal rivers.

The largest area of the formation in South Carolina lies between Darlington, Sumter, and Johnsonville, in Darlington, Sumter, Lee, Clarendon, Williamsburg, and Florence Counties. There is a smaller area in Marion County, and several patches in Berkeley and Dorchester Counties. The Duplin crops out in the bluff on the Georgia side of the Savannah River opposite Hampton County but appears to be absent from the adjacent lowlands in South Carolina.

The greatest thickness of Duplin marl that has been found in South Carolina is at Bostick Landing, on the Pee Dee River, where Sloan measured 41 feet of it. Generally it is less than 20 feet thick, and the prevailing thickness in Sumter and Lee Counties seems to be 12 feet. Miller reports a maximum thickness of about 100 feet in North Carolina.

The Duplin marl appears to have remained very nearly in the attitude in which it was deposited, although it now stands 100 feet or more above sea level at some places. No folds or flexures have been detected in it.

A large fauna, chiefly mollusks, is contained in the Duplin marl. The most prolific locality in South Carolina is in Sumter County, on the Muldrow place, near the Brick Church, 5 miles southeast of Mayesville. About 250 species of mollusks have been identified from this place, and most of them occur also in the typical Duplin marl of North Carolina. Among the species most commonly found in South Carolina may be mentioned Arca incile Say, Ostrea sculpturata Conrad, Ostrea disparilis Conrad, Amusium mortoni Ravenel, and Pecten eboreus Conrad, but as these are long-ranging species, the presence of any or all of them cannot be taken as a sure indication of the Duplin marl.

- Veatch, Otto, and Stephenson, L. W., op. cit., pp. 366-369.

- Sloan, Earle, op. cit. (Catalogue), pp. 473-475. 


\section{FLORENCE COUNTY}

Lynches River.-Sloan ${ }^{7}$ cites Pecten eboreus, Arca incile, and Venus rileyi from the low terrace east of the Lynches River 1 mile below the bridge of the Atlantic Coast Line Railroad near Cartersville (217).

About 6 inches of Duplin marl is visible at a spring at the edge of the swamp on the McCall property, 1.7 miles southeast of the railroad at Effingham (218). The marl contains Amusium mortoni, one or more species of Pecten, and oysters. Sloan ${ }^{8}$ reports Pecten eboreus, Arca incile, and Chama congregata from this place. At the mouth of Timmons Lake, on the east bank of the Lynches River 4 miles south of Effingham (219), he found a 7-foot bed of Duplin marl consisting chiefly of shells. The marl was covered by 33 feet of white sand; the bottom of the exposure lies 8 feet above low-water level. Duplin marl has been dug from the east bank of the Lynches River a short distance above Anderson Bridge (220), 4 miles east of Coward. ${ }^{9}$

Pee Dee River.-Exposures of the Duplin marl have been seen at several places along the west side of the Pee Dee River between Myers Landing (221), 11/2 miles northwest of the mouth of the Lynches River, and Savage Landing, 13/4 miles north of Poston.

In a cut on the road leading down to the river swamp at Myers Landing, 23 feet of marl is exposed. It is soft, gray or yellow, and sandy, and contains fragments of oyster shells, Pecten sp., and Amusium mortoni. The Duplin at Myers Landing is overlain by about 20 feet of yellow and red sand, chocolate-colored sandy clay, and yellow loam.

The following section at Bostick Landing, on the west side of the Pee Dee River 93/2 miles northwest of the mouth of the Lynches River, is adapted from Sloan. ${ }^{10}$

\section{Section at Bostick Landing (222)}

Pleistocene:

Feet

5. Sand and loam

Miocene (Duplin marl):

4. Dirty-buff sandy marl, granular and friable; mass of loose fragments of shells at base

3. Indurated dirty-yellow marl containing Pecten eboreus, Natica duplicata, etc. . . .

2. Granular buff porous marl; contains numerous casts in the upper part; Amusium mortoni is prominent in the lower part.

Upper Cretaceous (Peedee formation):

1. Not exposed along the river; blue-black sticky marl beneath shell rock struck in well at Bostick, half a mile west of the landing

\footnotetext{
i Sloan, Earle, op. cit. (Catalogue), pp. 308-309.

Idem, pp. 324-25.

I Idem, pp. 308-309.

10 Idem, p. 315.
} 
When this locality was visited during a period of moderately high water in September 1917 only 6 or 7 feet of soft yellow marl was exposed in the vertical bluff near the landing. The marl contained large barnacles, casts of mollusks, and shells of Ostrea sculpturata Conrad, Amusium mortoni Ravenel, and Pecten eboreus var. aff. $P$. eboreus darlingtonensis Dall (identified by W. C. Mansfield).

The section exposed at Davis Landing, $63 / 4$ miles northwest of the mouth of the Lynches River, is as follows:

Section at Davis Landing, Pee Dee River (223) ${ }^{11}$

Wicomico formation (Pleistocene):

Feet

5. Brown plastic clay with thin partings of fine sand, passing upward into fine yellowish sand with laminae of brown clay. To top of bluff

Duplin marl (Miocene):

4. Marlstone containing Ostrea sculpturata Conrad and Pecten eboreus Conrad (station 5303) ............

3. Projecting ledge of marl like bed 2 but somewhat harder; Cardium acutilaqueatum Conrad? and Venus rileyi Conrad? (station 5301); Arca incile Say and Chama congregata Conrad (station 5302); and Ostrea sculpturata Say (station 11846) .................

2. Cream-colored pulverulent calcareous marl with darkbrown phosphatic pebbles; Pecten eboreus Conrad, Arca aff. A. leonensis Mansfield, and Panope reflexa (Say) (station 11847)

Peedee formation (Upper Cretaceous):

1. Dark-brown fine sandy micaceous marl with discontinuous hard ledges near the top; Ostrea tecticosta Gabb, Gryphaea mutabilis Morton, Exogyra costata Say, Pecten simplicius Conrad, Lima acutilineata (Conrad), Anomia argentaria Morton, Crenella serica Conrad, Veniella conradi (Morton), and Sphenodiscus lobatus allisonensis Stephenson? (station 4159) .......... 23

According to Sloan, ${ }^{12}$ marl similar to that at Davis Landing rises about 18 feet above low-water level at Godfrey Landing and 26 feet above low water at Savage Landing, 13/2 miles and 1 mile, respectively, above the Seaboard Air Line Railway bridge near Poston.

\section{MARION COONTY}

Soft cream-colored to gray marl, probably Duplin, containing oyster shells, comes to the surface at the edge of the swamp of the Little Pee Dee River on the land of P. W. Stephenson (224). Broken shells are scattered on the ground, andlumps of marl can be dug up with a pick, but there is no measurable section. The exposure is in a field nearly three-quarters of a mile from the gate on the public road 2.1 miles south of Ariel Crossroads, which is on the highway from Conway to Marion, 3.6 miles from Galivants Ferry.

11 The Miocene fossils were Identifed by W. C. Mansfeld; the Cretaceous by L. W. Stephenson.

1s Sloan, Earle, op. cit. (Catalogue), pp. 316, 317. 
Tuomey ${ }^{13}$ lists Pecten eboreus, Ostrea virginiana, and 0 . disparilis from a 6-foot bed of marl exposed on a little stream not far from the Marion road on the $\mathrm{H}$. $\mathrm{H}$. Harrelson place, 2 or 3 miles from Galivants Ferry. Tuomey and Holmes ${ }^{14}$ list this locality under "Horry district", but Tuomey's original description seems to place it in Marion County.

\section{DARLINGTON COONTY}

Sparrow Swamp (225).--According to Sloan, ${ }^{15} 5$ or 6 feet of soft blue argillaceous marl containing Miocene shells (Arca incile, Pecten eboreus, Venus rileyi, etc.) is exposed at the foot of the bluff west of Sparrow Swamp, 4 miles southeast of Lamar.

Timmonsville Road(226).- In 1886 Frank Burns collected Duplin fossils from the Timmonsville Road 9 miles southwest of Darlington. If the mileage stated on the label is correct, this place must be on Middle Swamp, near the Darlington-Florence County line.

Darlington.-In the vicinity of Darlington the Duplin marl lies a few feet below the level of the swamps, and there are few if any natural exposures. Tuomey mentions several farms where the marl had been dug. Burns, in 1886, collected 54 species of shells near the courthouse (station 2024); on Shell Branch, 1 mile east of Darlington (station 2025); and on the old Chancellor Dargan place, on the north side of Swift Creek, 2 miles north of Darlington (station 207). Sloan and Vaughan collected about 62 species of mollusks and several other organisms from a small creek back of Miss Annie Williamson's residence at Darlington (station 5298).

SUMTER COUNTY

Brick Church (227).-A classic locality of the Duplin marl is on the Muldrow estate, 0.7 mile northeast of the Brick Church, which is on the Black River Road 5 miles southeast of Mayesville. The only exposures visible in 1917 were in a few shallow pits in a drain leading into Church Branch. The marl consists of shells in fine clear quartz sand. According to Sloan, ${ }^{18}$ it is 12 feet thick. A large collection (station 4000) made there for the United States Geological Survey in 1904 by Sloan and Burns yielded about 250 species of mollusks, many of which occur also in the Duplin marl of North Carolina. The mollusks from the Muldrow place have been listed by Gardner and Aldrich. ${ }^{17}$

Shiloh-Lynchburg road.-The Duplin marl is penetrated by wells in the eastern part of Sumter County. According to drillers, white shells are first encountered about 1 mile north of the Clarendon

13 Tuomey, Michael, op. cit., p. 175.

11 Tuomey, Michael, and Holmes, F. S., op. cit., p. xi.

16 Slogn, Earle, op. cit. (Catalogue), pp. 307-308.

16 Idem, p. 308.

17 Gardner, Julia, and Aldrich, T. H., Mollusca from the upper Miocene of South Carolina, with descriptlons of new species: Acad. Nat. Sci. Philadelphia Proc., vol. 71, pp. 17-53, pls. 1-4, 1019. 
County line; at Spring Branch they lie on blue clay 3 or 4 feet below the surface. In Mr. Cunningham's well near Pleasant Grove School (228), 3.7 miles north of Shiloh and 5.5 miles south of Lynchburg, the marl lies about 35 feet below the surface and is 12 feet thick. It is underlain by soft blue "rock" that is probably either the Black Mingo or the Black Creek formation.

Hicks Landing (229).- Sloan ${ }^{18}$ reports Miocene marl in the bed of the Lynches River at Hicks Landing, 1 mile below Hudson Bridge, which is 6 miles north of Olanta.

\section{BEREELEY COONTY}

Porcher plantation (230).-Tuomey ${ }^{19}$ describes an occurrence of the Duplin marl as follows

The next locality along the outer edge of the formation is found below Eutaw, in St. John's Berkley, on the plantation of Mr. T. Porcher. Like the bed in Sumter, just described, it is composed of white comminuted shells. The fossils that can be identified are barely sufficient to enable one to determine its age. They are Ostrea disparilis, Pecten septemnarius, Venus rileyi, and Fusus [Ecphora] quadricostatus. This must be the locality "below the conflence of the Congaree and Wateree Rivers", whence fossils were sent by the late Stephen Elliott, Esq., from which Conrad inferred the existence of the Middle Tertiary in South Carolina. Like the rest of the principal Pliocene [Miocene] beds, when they are not exposed on the banks of streams, this is found below the surface and is only seen in the pits where marl is raised for agricultural purposes.

The pit from which Tuomey obtained these fossils may be on the tract called Cedar Springs, which lies north of the Eutawville road 6 to 7 miles west of Bonneau.

Old Carson place.-According to Tuomey, ${ }^{20}$ shells of Pecten eboreus were found in digging a ditch on the old Carson place on the Cooper River. This is the highest place on the river at which he saw indications of the late Tertiary marl.

Dean Hall (231).-Dean Hall, west of the Cooper River just above the forks, is cited by Tuomey and Holmes ${ }^{21}$ as one of the localities at which fossils were obtained. Sloan ${ }^{22}$ records only Cooper marl there.

\section{DORCHESTER COONTY}

Givhans Bridge (170).- Remnants of the Duplin marl lie upon the Eocene Cooper marl on the east bank of the Edisto River at Givhans Bridge, 2 miles below the mouth of Four Hole Swamp. It is gray or white, hard at places, and contains phosphatic pebbles and Turritella cf. T. etiwanensis Tuomey and Holmes, Ostrea disparilis, Pecten eboreus, Amusium mortoni, and Arca improcera. The harder parts of the marl so greatly resemble a ledge at the top of the Cooper

19 Sloan, Earle, op. cit. (Catalogue), p. 323.

10 Tuomey, Michael, op. cit., pp. 178-179.

${ }^{20}$ Idem, p. 179.

21 Tuomey, Michael, and Hoimes, F. S., op. cit. p. xi.

${ }^{22}$ Sloan, Earle, op. cit. (Catalogue), p. 295. 
marl that they can be distinguished only by the fossils in them, but the texture of the softer parts is more mealy. The Eocene bed contains many Bryozoa and large oysters (Ostrea podagrina). No Miocene marl is exposed along the present road to the bridge, but along the road to the old ferry about 2 feet is visible.

\section{PLIOCENE SERIES}

\section{GENERAL FEATURES}

During the Pliocene epoch most of the northern half of the present continental shelf was probably land, and the adjoining mainland stood higher than now. This may account for the southward course of many of the rivers of New England, the Hudson River, and Delaware and Chesapeake Bays, both of which were then river valleys. It was probably at this time that Long Island Sound (also a drowned valley) and the submerged valley off the mouth of the Hudson were excavated.

South of Cape Hatteras the land stood lower. Not only was the present continental shelf submerged, but the margin of the present land was under water and marine shell beds accumulated upon it. These deposits include the Croatan sand of North Carolina, the Waccamaw formation of North and South Carolina, and the Caloosahatchee marl of Florida, all of which are contemporaneous, and possibly also the Charlton formation of Georgia and Florida, which is questionably referred to the Pliocene. Along the border of the Gulf of Mexico an extensive deposit of sand and gravel, the Citronelle formation, is supposed to have been laid down at the same time.

While these marine deposits were accumulating in the sea deposits of various kinds were accumulating on the land. Lake beds, sinkhole and cavern fillings, and residual sand and clay derived from the phosphatic Miocene Hawthorn formation gave rise in Florida to the Alachua formation; and sedimentary and residual deposits laid down near the mouth of a Pliocene river in Florida made up the Bone Valley gravel. These two formations contain commercial phosphate deposits. At this time many of the large rivers built alluvial fans of sand and gravel brought down from the hills. The deposit laid down by the Susquehanna River in Pennsylvania and Maryland in Pliocene(?) time is the Bryn Mawr gravel; others have not received special names. In South Carolina such deposits lie east of the Pee Dee River in the northern part of Marlboro County and probably also near the Wateree, Congaree, and Savannah Rivers. Part of Sloan's †Cheraw cobbles ${ }^{23}$ is a deposit of this kind.

The deposition of these marine and continental formations was stopped by the widespread movements of the land that ended the

${ }^{23}$ Sloan, Earle, op. cit. (Catalogue), p. 476.

$143491-36-9$ 
Pliocene epoch. The northeastern part of the United States sank until the Coastal Plain was almost completely submerged. South Carolina also went down, perhaps about 170 feet, but not so much as the land farther north. Florida was tilted to the west.

\section{WACCAMAW FORMATION \\ GENBRAL CHARACTER}

The name "Waccamaw beds" was adopted by Dall ${ }^{24}$ in 1892 "for the beds exhibited in South Carolina along the Waccamaw, above the Cretaceous marl, as sectionized by Tuomey and Johnson", and the name "Waccamaw formation" has since come into general use for the marine Pliocene of the Carolinas. For South Carolina, Dall's description is the most complete on record; for North Carolina, that by Miller ${ }^{25}$ is the most adequate.

The Waccamaw lies unconformably upon an old land surface that included formations of several ages. In Horry County and in the eastern part of Georgetown County it rests upon the Upper Cretaceous Peedee formation. If it is present in Georgetown County west of the Black River, it probably lies on the lower Eocene Black Mingo formation. In Berkeley County it either lies on the upper Eocene Cooper marl or is separated from the Cooper by a thin Miocene deposit. Where it does not form the surface of the ground, the Waccamaw formation is covered by Pleistocene or Recent deposits.

The distribution of the Waccamaw formation as shown on plate 2 is partly hypothetical, for natural exposures of it are confined to the banks of rivers and are very scarce. It probably occupies a broad belt that extends parallel to the coast from the North Carolina boundary through Horry County and part of Georgetown County. A smaller patch that crosses the Cooper River and Goose Creek in Berkeley County possibly extends a short distance into Charleston County. The Waccamaw appears to include several thin shell beds separated by sand, but it is doubtful whether more than one faunal zone can be recognized in it. The total thickness of the formation in South Carolina probably does not much exceed 25 feet, which is suspected to be the maximum thickness in North Carolina.

The deposits now called "Waccamaw formation" were classed as Pliocene by Tuomey because they contained a greater proportion of Recent species than the Miocene deposits of Virginia and Maryland. For a while this correlation was discredited, and the deposits were deemed to be Miocene because Tuomey included in his so-called "Pleiocene" the shell marls of Sumter and Darlington Counties (Duplin

at Dall, W. H., Contributions to the Tertiary fauna of Florida: Wagner Free Inst. Sci. Trans., vol. 3, pt. 2, p. 200, 1892.

2s Miller, B. L., North Carolina Geol. and Econ. Survey, vol. 3, pp. 250-258, 1912. 
marl), which are really Miocene ${ }^{26}$ as well as the Waccamaw formation, which is Pliocene. The discovery that Tuomey's so-called "Pleiocene" included two faunas of different ages is the work of Dall. ${ }^{27}$

\section{HORRY COUNTY}

Little River.-Exposures of marl believed to represent the Waccamaw formation on the Little River are described by Tuomey ${ }^{28}$ as follows:

At the Timber Landing, below Capt. Randal's dwelling and on the same side of the river, a bed is exposed the upper surface of which is about the level of high water. It is laid bare at low water, in the sloping beach extending into the bed of the stream. A little higher it seems to thin out in a bed of blue clay containing Mactra lateralis in great abundance and is the only deposit in the State that reminds me of the Virginia Miocene. Resting upon the marl is a bed of marsh mud 2 or 3 feet thick, which is but an extension of the marshes on the shore a few miles lower down. Superimposed upon this is a bed of incoherent sand, similar to the loose, moving sands along the coast but now rendered permanent by the growth of plants, including large liveoaks. Immediately under the mud the marl is quite ferruginous, but lower it assumes a bluish tinge. The calcareous portion is between 8 and 12 feet in thickness.

I saw this bed exposed higher up the river, at Mr. Bessant's, where it occupies the bed of the stream, and still higher, some distance inland, at Mr. Vaught's, where it occurs 6 or 8 feet below the surface.

At the mouth of the river I collected Pliocene and Cretaceous fossils, mingled together as they were thrown up by the waves on the shore, showing that these formations extend under the waters of the Atlantic.

Tuomey lists from these localities the following Pliocene mollusks:

Infundibulum depressum

Crepidula fornicata

Natica duplicata

Natica caroliniensis

Trochus philantropus

Turritella alticosta

Fusus cinereus

Pyrula carica

Oliva litterata

Conus adversarius

Columbella avara

Marginella limatula

Cypraea pediculus

Pholas turgidus

\begin{tabular}{|l} 
Solecurtus caribaeus \\
Myalina subovata \\
Mactra lateralis \\
Donax variabilis \\
Astarte concentrica \\
Astarte radians \\
Cytherea sayana \\
Artemis acetabulum \\
Venus cribraria \\
Carditamera arata \\
Pectunculus subovatus \\
Pectunculus quinquerugatus \\
Chama congregata \\
Ostrea virginiana
\end{tabular}

Intracoastal Waterway.-In 1934, when the canal about 3 to $51 / 2$ miles southwest of the village of Little River was being cut, the dredge cast up on the southeast bank great quantities of fossil shells. Many

${ }^{26}$ Heilprin, Angelo, On the relative ages and classiffation of the post-Eocene Tertiary deposits of the Atlantic slope: Contributions to the Tertiary geology and paleontology of the United States, pp. 41-68, Philadelphia, 1884.

${ }^{27}$ Dall, W. H., Contributions to the Tertiary fauna of Florida: Wagner Free Inst. Sci. Trans., vol. 3, pt. 2, p. 216, 1892.

28 Tuomey, Michael, op. cit., pp. 171-172. 
of the shells came from the Pleistocene Pamlico formation, but the underlying irregularly indurated gray sandy marl yielded such characteristic Pliocene mollusks (identified by W. C. Mansfield) as Pecten ernestsmithi Tucker, Pecten eboreus senescens Dall, and Scaphella floridana (Heilprin). This rock also contained several species of echinoids, including Rhyncholampas evergladensis (Mansfield), a Clypeaster, an Encope, and a Coelopleurus (station 13377).

Waccamaw River.-Exposures of Waccamaw marl on the Waccamaw River have been described by Tuomey, ${ }^{29}$ by Dall ${ }^{30}$ (who based his description on an unpublished report by C. W. Johnson), and by Sloan. ${ }^{31}$ The lowest locality on the river that has been reported is Grissetts Landing, which is probably on the south side about $21 / 2$ miles east of Conway, and the highest, according to Sloan, is near the North Carolina line. The marl everywhere rests unconformably upon the Upper Cretaceous Peedee formation, and it is generally overlain by Pleistocene sand. At Porters Landing and at Harpers (51), according to Tuomey, the Waccamaw is 8 to 12 feet thick, and the overlying sand is 30 to 40 feet thick.

The best-known locality, which has yielded the greatest number of fossil shells, is near the mouth of Tilly Lake (52), near Nixonville. At this place the marl is said to be $10 \%$ feet thick, gray except an oxidized yellowish-brown zone at the top, and full of shells.

Dall summarized Johnson's observations along the Waccamaw River as follows:

The banks of the Waccamaw River are for the most part low, and in the $\mathbf{3 6}$ miles examined there were only three places where specimens could be obtained. About 4 miles above Conway is Grissetts Landing, but the supply of fossils being represented as small, Mr. Johnson did not delay here. An approximate section at the landing gave-

Soil, 4 to 5 feet.

Shell marl, 2 to 3 feet.

Blue (Cretaceous) marl, 4 feet to the water.

The first locality of importance is at Mr. William Nixon's (called Harpers Landing by Tuomey), about 15 miles from Conway by the river and half that distance in a direct line. Here the following section was taken:

Soil and ferruginous sand, about 20 feet.

Shell marl (the lower 4 feet much decomposed), 11 feet.

Blue (Cretaceous) marl without fossils, 8 feet.

Three miles above this is Nixonville, or Grahamville, near which is Tillys Lake, a tributary of the Waccamaw. Near the mouth are some very important outcrops, giving the following section:

Soil and ferruginous sand, about 20 feet.

Shell marl (Pliocene), 9 to 10 feet.

Blue (Cretaceous) marl with Exogyra costata, $2 \frac{1}{2}$ feet.

Exogyra occurred in the Pliocene marl to the height of a foot above the level of the blue marl, being, of course, adventitious.

20 Tuomey, Michøel, op. cit., pp. 172-174.

I Lall, W. H., op. c.t. (1892), pp. 204-205.

s Sloan, Earle, op. cit. (Catalogue), pp. 321-323. 
At Bear Bluff [232], about 6 miles above the lake, is an outcrop of decomposed shell marl about 6 feet thick, but affording little in the way of fossils.

The next place of importance is Todds Ferry, which is probably the locality cited by Tuomey under the name of "Royal Ferry." It is about 12 miles from Conway by land but nearly three times as far by the tortuous course of the river. Here were found

Soil, 4 to 6 feet.

Shell marl, lower half much decomposed, 8 feet.

Sand with Pecten eboreus and Ostrea meridionalis, 3 feet.

The Cretaceous was not visible here. Two miles above is Red Bluff [233] where the marl is so indurated as to afford few specimens, but they were identical with those previously found. The following section was made:

Soil and ferruginous sand, about 10 feet.

Indurated shell marl, 5 feet.

The lower decomposed marl appears to be identical with the upper part of the bed, for at Tillys Lake, where they were best preserved, the same species were found in both parts of the bed.

The Waccamaw formation was exposed in 1917 on the east bank of the Waccamaw River at a house about three-quarters of a mile above Reeves Ferry (Vina?) and half a mile or less below Bear Bluff. Cream-colored to yellow marl containing oysters and other shells extends 8 or 10 feet above water level. The shells appear very fresh and retain much of their original color. The marl is said to be much better exposed at Bear Bluff (232), 2 miles north of Nixonville.

\section{GEORGETOWN COUNTY}

Yauhannah Ferry (234). - Waccamaw marl is exposed at low tide on the west bank of the Pee Dee River at Yauhannah Ferry, where the following section was measured in 1917:

Section on right bank of Pee Dee River at Yauhannah Ferry

Pleistocene(?):

4. Red clay to top of bluff

Pliocene(?) (Waccamaw(?) formation):

3. Reddish-yellow argillaceous sand with imprints of mollusks...... 3

2. Fine yellow to red sand $\ldots \ldots \ldots$

Pliocene (Waccamaw formation):

1. Coarse blue-gray to yellow shell marl; exposed between tides.

The fossils that were collected from bed 1 are listed below:

7972. Pee Dee River at Yauhannah Ferry, road from Georgetown to Conway; C. Wythe Cooke, collector, 1917; identified by W. C. Mansfield:

Planc:bis sp.

Physa aff. P. meigsii Dall

Acteocina caniculata (Say)

Terebra dislocata indentata Conrad

Marginella aureocincta Stearns

Marginella, $2 \mathrm{sp.}$

Oliva litterata Lamarck
Olivella mutica (Say)

Olivella nitidula Dillwyn

Mitra wandoensis Holmes

Ilyanassa irrorata Conrad

Triforis sp.

Seila adamsi (H. C. Lea)

Caecum cooperi S. Smith 
Caecum ibex Dall

Trivia sp.

Vermicularia spirata Phil.

Littorina irrorata carolinensis Conrad?

Fissuridea aff. F. alternata Say

Dentalium aff. D. disparile D'Orbigny

Nucula proxima Say

Yoldia sp.

Glycymeris pennacea Lamarck

Glycymeris aff. G. duplinensis Dall

Glycymeris americana Defrance

Arca lienosa (Say)

Arca aff. A. transversa Say

Arca adamsi Shuttleworth

Ostrea virginica Gmelin

Ostrea sculpturata Conrad

Pecten eboreus aff. var. solaroides Heilprin

Plicatula sp.
Astarte concentrica Conrad
Crassinella lunulata Conrad
Cardita (Carditamera) sp.
Venericardia tridentata Say Venericardia perplana abbreviata Con-
rad
Venericardia granulata Say
Phacoides waccamawensis Dall
Phacoides radians Conrad
Gouldia metastriata Conrad
Gemma magna Dall
Chione grus Holmes
Chione cribraria Conrad
Chione latilirata athleta Conrad
Venus rileyi Conrad
Donax ef. D. fossor Say
Mulinia lateralis Say
Corbula inaequalis Say
Rangia clathrodonta (Conrad)

Most of the species that have been identified from Yauhannah lived as early as Miocene time, and many of them still survive. The presence of Phacoides waccamawensis, Vermicularia spirata, and Ostrea virginica indicate that the fauna is probably of Pliocene age, although Rangia clathrodonta and Yoldia sp. point to the Miocene. The fauna is very similar to that of Neils Eddy Landing, N. C., which has been referred to the Waccamaw formation by Miss Gardner ${ }^{32}$ and is probably contemporaneous with it.

Black River (235).-Fossil shells like those at Yauhannah Ferry were found on the west bank of the Black River at a bluff known as "The Hill" or "Evans Bluff", on J. J. Evans' farm, 13/2 miles by water below Pea House Ferry (Georgetown waterworks). The section is as follows:

\section{Section of Waccamaw formation at Evans Bluff, Black River}

5. Small covered interval to top of bluff.

4. Coarse sandy shell marl; mollusks and a coral very abundant (station 7971); base is irregularly intermingled with top of

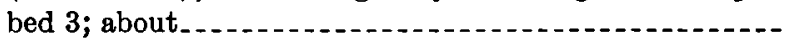

3. Very fine brown to yellow sand, passing into compact sandy marl at top........... 6

2. Very hard, gray compact sandy marl or limestone containing casts of many mollusks in the lower part....... $1 \frac{1}{1}$

1. Very fine gray to brown incoherent sand; to high-tide level_ 3

The better-preserved species from bed 4 have been identified as follows:

7971. Evans Bluff, Black River; C. Wythe Cooke, collector, 1917; identified by W. C. Mansfield:

32 Gardner, Julia, North Carolina Geol. and Econ. Survey, vol. 3, pp. 323-325, 1912. 
Turritella sp.

Leda acuta (Conrad)

Glycymeris americana Defrance

Glycymeris pennacea Lamarck

Arca adamsi Shuttleworth

Ostrea sculpturata Conrad

Pecten eboreus aff. var. solaroides Heilprin

Crassinella lunulata Conrad

Venericardia perplana abbreviata Conrad
Venericardia tridentata Say

Venericardia granulata Say

Phacoides waccamawensis Dall

Phacoides multilineatus Tuomey and Holmes

Gouldia metastriata Conrad

Gemma magna Dall

Venus sp.

Corbula inaequalis Say

\section{BEREELEY COUNTY}

The Grove (236).-The Grove, noted as the type locality of Amusium mortoni (Ravenel), Encope macrophora (Ravenel), Echinocardium gothicus (Ravenel), Brissus spatiosus (Ravenel), and Metalia raveneliana (McCrady), lies east of the Cooper River and 5 miles northwest of Wando. The plantation was visited by Lyell in 1841 or 1842 and described by him in $1845 .^{33}$ Lyell thought that the 5 feet of marl he saw in a ditch a quarter of a mile or more south of the house was Eocene, like the marl exposed farther north on the Cooper River, but Tuomey referred it to the Pliocene. Besides the fossils mentioned above, Tuomey lists from The Grove Pecten eboreus, Cardium sublineatum, Solen ensis, Voluta mutabilis, Venus cribraria, and Oliva litterata. ${ }^{34}$

Yeamans Hall (237).- -Soft yellowish marl rises about 8 feet above low tide in the bluff on the southeast side of Goose Creek near Yeamans Hall, east of the Seaboard Air Line Railway bridge and threequarters of a mile southeast of Melgrove. The marl contains many large Amusium mortoni, large barnacles, and a few other fossils, as noted in the following list:

10412. Bluff on southeast side of Goose Creek a third of a mile southeast of Seaboard Air Line Railway and three-fourths of a mile southeast of Melgrove; C. Wythe Cooke, collector, 1922; identified by W. C. Mansfield:

Liotia aff. L. major Gardner Mitra aff. M. dalli Gardner Pecten hemicyclicus Ravenel Amusium mortoni Ravenel Ostrea sculpturata Say

Ostrea sp.
Plicatula marginata Say

Mytilus sp.

Balanus sp.

Puellina radiata Moller; identified by

R. S. Bassler

Encope macrophora (Ravenel)

Fossiliferous marl at this place was first noted by Ruffin, ${ }^{35}$ who referred it to the Miocene. Tuomey ${ }^{36}$ called it Pliocene and listed 15

\footnotetext{
3s Lyell, Charles, Observations on the White limestone and other Eocene or older Tertiary formations of Virginia, South Carolina, and Georgia: Geol. Soc. London Quart. Jour,, vol. 1, pp. 432-433, 1845.

8. Tuomey, Michael, op. cit., p. 179.

ss Ruffin, Edmund, Report of the commencement and progress of the agricultural survey of South Carolina for 1843 , pp. 28-29, 1843 .

3s Tuomey, Michael, op. cit., p. 179.
} 
species from it. Tuomey and Holmes ${ }^{37}$ referred to the locality as "Smith's, Goose Creek."

The marl beds on the Cooper River near The Grove and on Goose Creek near Yeamans Hall appear to occupy the same stratigraphic horizon. The age is obviously either uppermost Miocene or Pliocene, but the evidence of the fauna is inconclusive. A few species have not been found elsewhere in beds younger than upper Miocene, but Encope macrophora and several mollusks seem to be restricted to Pliocene or younger deposits. The marl beds at these places, therefore, are here tentatively referred to the Waccamaw formation, but they may properly belong to the Duplin.

\section{PLEISTOCFNE SERIES \\ FLUCTUATIONS OF SEA LEVEL}

At the beginning of the Pleistocene epoch more than three-fourths of the Coastal Plain of South Carolina was covered by the sea. Little more than the innermost tier of counties then stood above the water, and these were cut through by several wide bays that penetrated inland to the edge of the Piedmont. The Savannah River widened into a bay at Augusta; the Saluda and the Broad entered Congaree Bay at Columbia; the Wateree became a bay at Camden; and the Pee Dee Bay extended past Cheraw to the North Carolina line. These bays were the drowned valleys of the rivers emptying into them. The sea at this time is thought to have stood about 270 feet above its present level. Later in Pleistocene time the sea stood successively at levels of about $215,170,100,70,42$, and 25 feet higher than its present stage, and possibly at other levels that have thus far escaped detection. However, the lowering of the sea from its early Pleistocene high level to its present stage did not take place by an uninterrupted series of downward steps but by a series of oscillations in most of which the water sank to a low-level stage considerably below its present position before it rose again to the next recorded high-level stage. These fluctuations are discussed further on page 157 .

MARDNE FORMATIONB

Along the Atlantic seaboard the Pleistocene series comprises seven formations corresponding to the seven high stages of the sea mentioned above. Beginning with the oldest, these formations and the approximate height above sea level of their shore lines are as follows:

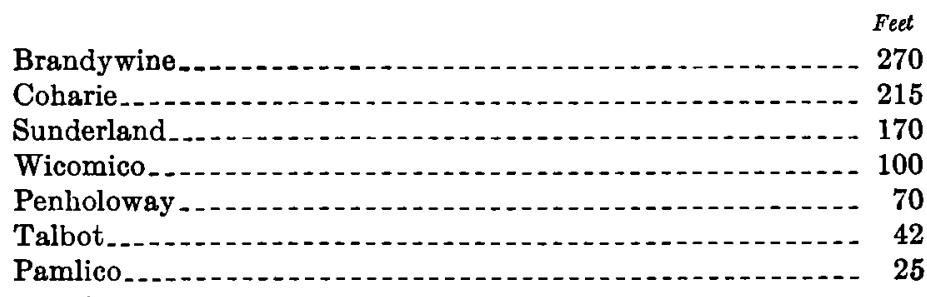

n Tuomey, Michael, and Holmes, F. S., op. cit., p. 4. 
The landward limit of each formation was originally the shore of the sea and its estuaries at the corresponding stage. Many remnants of these shore lines can still be detected, although erosion has broken their continuity at some places; their approximate locations are shown in plates 4 to 10. One Pleistocene formation is separated from another largely upon the basis of topography, for its surface is a terrace or plain that lies between the level of its own shore line and that of the next younger formation. The general profile is shown in figure 2.

None of the Pleistocene formations are very thick, and nowhere in South Carolina is there a complete series of one upon another. Most of the gravel, sand, and clay of which they are chiefly composed was dropped near shore, and little of it was carried as far out to sea as the present coast. Therefore, the pre-Pleistocene formations crop out above sea level not far from the coast, where one might expect them to be deeply buried, and the waves have cut into them at some places on the shore. It is unlikely that much Pleistocene material was eroded away when sea level was low during the glacial stages, for the duration of these low-water periods was probably comparatively short, and erosion of wide low-lying plains, such as a newly emerged sea bottom, is very slow.

The Pleistocene formations in South Carolina consist chiefly of sand and clay. The younger formations generally contain less coarse materials than the older; they are composed largely of fine sand and clay that was washed out of the older deposits, carried into the sea, and distributed by waves and currents that were too weak to transport coarse sand and gravel.

The problem of the correlation of the marine Pleistocene formations of the Coastal Plain with the continental Pleistocene deposits of the Northern States is difficult of direct solution because the most complete development of the continental deposits is far inland. Where the two kinds of deposits occur together the sequence is incomplete and little attempt has been made to determine their relative ages. Moreover, most of the continental deposits were formed during glacial stages, when the sea was lower than its present level and no marine deposits were being formed upon the present land surface of the Coastal Plain. Conversely, all the marine Pleistocene deposits of the Coastal Plain are thought to have been formed during interglacial stages, when deposition of continental deposits in the Northern States was at a minimum.

\section{BRANDYWINE FORMATION}

The Brandywine formation was named by Clark ${ }^{38}$ in 1915 from a village in Prince Georges County, Md., near which its gravel, sand, and loam are exposed. As Clark included in the formation some de-

\footnotetext{
a Clark, W. B., The Brandywine formation of the Middle Atlantic Coastal Plain: Am. Jour. Sci., 4th ser., vol. 40, pp. 499-506, 1915.
} 
posits that are now known to be older and others that are younger than those at Brandywine, the formation was restricted ${ }^{39}$ in 1931 so as to include only those that, as I interpret them, accumulated in the seas and estuaries in early Pleistocene time, while the sea stood about 270 feet higher than its present level.

The boundaries of the Brandywine formation shown on plate 1 are approximate only and will doubtless be considerably modified by detailed mapping. Detailed geologic mapping of the Brandywine is slow and tedious, because for much of the area covered by it no topographic maps are available. The formation has been considerably dissected and may be absent entirely from parts of the area indicated as Brandywine on plate 1. Moreover, in the brief reconnaissance of the Pleistocene formations no certain criteria were discovered for separating the Brandywine from older deposits, particularly from the Barnwell and Black Mingo formations.

The Brandywine formation consists chiefly of red sand and sandy loam. Large well-rounded pebbles are abundant at places, particularly near the larger rivers.

COHARIE FORMATION

GENERAL CHARACTER

The name "Coharie formation", from Great Coharie Creek, a tributary of the Black River in North Carolina, was proposed in 1912 by Stephenson ${ }^{40}$ to include the terrace deposits that underlie the Coharie terrace. The limits of altitude assigned to the Coharie terrace in North Carolina were 160 and 235 feet above sea level, but these limits are respectively a little too low and too high and include parts of the adjacent terraces. In South Carolina, where topographic maps covering a greater area are available, the old shore line of the terrace has been considerably eroded and modified by subterranean solution, but it appears to have stood 215 feet above sea level; its approximate location is shown in plate 9 . The outer or seaward margin of this terrace is very obscure in South Carolina.

In South Carolina the Coharie formation consists chiefly of gravel, sand, and sandy clay. The color is variable, depending partly on the source of the materials composing it and partly on the degree of oxidation or leaching that they have undergone. Light grays, yellows, and pinks are common, but various hues of red are not unusual. The formation is not thick; along the North Carolina border it is probably about 50 feet thick, but farther west it is generally thinner.

The Coharie formation extends entirely across the State from Marlboro County to Allendale County, but it is cut through by all

" Cooke, C. W., Seven coastal terraces in the southeastern States: Washington Acad. Sci. Jour., vol. 21, p. $506,1931$.

io Stephenson, L. W., North Carolina Geol. and Econ. Survey, vol. 3, p. 273, 1912. 
the larger rivers and streams. Its inner margin, where it abuts against older formations, runs approximately parallel to the present Atlantic coast at a distance of 80 or 90 miles inland.

\section{MARLBORO COUNTY}

Cottingham Creek (238).-Coarse gravel, apparently of the Coharie formation, is exposed on the descent to Cottingham Creek on the road from Tatum to Bennettsville, 1 mile above Covington Mill.

Naked Creek (239).--Red pebbly sand is exposed along the roadside west of Naked Creek near Bullards Mill, 63/4 miles northwest of Bennettsville. The altitude is probably about 175 feet above sea level.

Wire Road.-Near Ebenezer Church (240), on the Wire Road 41/2 miles northeast of the bridge at Cheraw, 15 feet of light-gray to pink coarse argillaceous sand, containing a few pebbles 2 or 3 inches in diameter and pellets of pink clay near the bottom, is underlain unconformably by white clay and fine sand of the Tuscaloosa formation. The altitude at the church, as inferred from barometric readings, is about 185 feet above sea level.

An exposure on the Wire Road 6 miles northeast of Cheraw and 0.6 mile beyond Smith's mill (241), shows about 10 feet of coarse red, pink, and gray argillaceous sand containing zones of coarse subangular to well-rounded pebbles, a few of which are as much as 3 inches in diameter. This sand lies with marked unconformity upon coarse white and pink cross-bedded sand of the Tuscaloosa formation. The top of the hill is about 220 feet (barometric reading) above sea level.

\section{CHESTERFIELD COUNTY}

Society Hill road (242).--Extensive deposits of loose yellow sand and coarse round pebbles have been excavated for railroad ballast along the Society Hill road, half a mile south of Cash. The road near the pits is about 195 feet above sea level. This gravel bed may be an old river terrace rather than a part of the Coharie formation.

DARLINGTON COUNTY

Society Hill-Hartsville road (243).--On the Hartsville road, 3.2 miles southwest of the railroad station at Society Hill, fine sand with a few large angular pebbles embedded in white clay grades downward into coarse pebbly sand and thence into large round pebbles. The top is about 180 feet above sea level. A rolling plain at the same altitude 5 miles southwest of Society Hill is underlain by fine clear quartz sand embedded in white clay that contains some mica and a few black particles. The deposit resembles the Tuscaloosa formation but is probably the Coharie.

Hartsville (9).-The materials underlying the Coharie terrace are well exposed in a gully known as the "cave" that crosses Home 
Avenue at the beginning of the 1700 block on the west edge of Hartsville. The lowest beds exposed, consisting of 5 feet of light-gray plastic clay passing upward into about 15 feet of gray and yellow plastic clay, then to loose sand, apparently represent the Upper Cretaceous Tuscaloosa formation. The very irregular upper surface of the Tuscaloosa is covered by 10 to 25 feet of coarse weathered red sand that extends to the top of the gully.

sparrow Swamp (244).-Light blue-gray angular sandy clay is underlain by coarse sand and angular gravel containing a few lumps of pink sandy clay on the Bishopville road at Sparrow Swamp, 2.7 miles southwest of Lydia. The material appears to be Coharie formation derived from the Tuscaloosa. It is about 200 feet above sea level.

\section{LEE COUNTY}

Bishopville.-The Coharie plain between Bishopville and Wisacky is covered with light-yellow sand. On the Mannville road 2 miles southwest of Bishopville coarse gray sand is exposed in a ditch; and 2.1 miles north of Mannville (245) there is coarse mottled reddish yellow argillaceous sand.

Meredith (246).-At Meredith (altitude 207 feet) coarse red argillaceous sand exposed in a railroad cut passes downward, toward the northeast, into white sandy clay.

Mechanicsville (247).-About 6 or 7 feet of blue-gray plastic sandy clay weathering yellow and passing upward into yellow sandy loam is exposed in the mill race at Mechanicsville, 2 miles south of Meredith. The material is probably part of the Coharie formation; if not, it may be Black Mingo (Eocene).

Elliott (248).-Medium-coarse yellow sand containing a few small pebbles is exposed on the descent to Stony Run 0.6 mile southwest of Elliott. The altitude of Elliott is 177 feet.

St. Charles.-The following section is exposed near the Black River 1.3 miles northeast of St. Charles:

Section on Black River near St. Charles (249)

Coharie (?) formation (Pleistocene):

2. Coarse reddish yellow sandy clay

Black Mingo (?) formation (Eocene?):

1. Fine gray sand containing scattered black grains, probably glauconite; weathers bright red; hard ledges of ferruginous sandstone at top

About 5 feet of loose white to yellow sand is exposed at an altitude of 168 feet in a cut of the Atlantic Coast Line Railroad (250) at a road crossing half a mile northeast of Scape Oer Swamp and 3 miles southwest of St. Charles. Large blocks of limonitic sandstone, presumably derived from the Black Mingo formation, are exposed on the road at a lower level 0.2 mile south of the railroad. 
BUMTER COUNTY

Southern Railway (251).-A cut on the Southern Railway at a road crossing $3 \frac{12}{2}$ miles southwest of Sumter shows the following sequence:

Section at Southern Railway crossing $3 \frac{1}{2}$ miles southwest of Sumter

Coharie formation (Pleistocene):

Feet

2. Hard yellow sandy clay; about.............. 8

Black Mingo (?) formation (Eocene):

1. Fine light blue-gray mealy sand and clay, weathering mottled red and yellow; contains lenses of coarse sand and gravel; top 6 feet below level of track; local ledge of ferruginous sandstone at top............ 3

Tuomey (252).-A drainage ditch about three-quarters of a mile south of Tuomey station on the Southern Railway and about 2 miles northwest of Privateer reveals about 12 feet of white to bluish fine sand containing small pebbles embedded in tough bluish clay.

Pinewood (253).-At a stream crossing $3 \frac{1}{2}$ miles west of Pinewood ledges of silicified sandstone containing many Black Mingo fossils are overlain by coarse mottled gray and red argillaceous sand and gravel that become very red at the top. The sand and gravel resemble those at Pocalla but may be Eocene.

Coarse gray micaceous sand and clay, probably Coharie, overlie brick-red argillaceous sand, probably Black Mingo, at Sammy Swamp, midway between Pinewood and Paxville (254).

Sumter.--Excavations made in 1917 at the waterworks at Sumter showed the following section:

\section{Section of Coharie(?) formation at Sumter}

2. Pale yellow sand; altitude at top 170 feet above sea level_._- 5

1. Fine canary-yellow sand containing a few small specks at bottom, becoming more argillaceous at top...........

ORANGEBURG COUNTY

Five Chop Road (255).-On the Five Chop Road about 9 miles east of Orangeburg a drainage ditch about 15 feet deep cuts into fine to coarse white sand containing small black specks. This sand weathers yellowish red. The altitude at the cross roads is 175 feet above sea level.

Orangeburg.-Coarse gray, yellow, and red argillaceous sand containing well-rounded pebbles, some of which are as much as $2 \frac{1 / 2}{\text { inches }}$ in diameter, is overlain by yellow sandy clay at the Atlantic Coast Line railroad station at Orangeburg.

At a drain on the south edge of Orangeburg (256) on the Charleston road midway between the crossings of the Atlantic Coast Line Railroad and the Southern Railway, coarse pebbly yellow sand lies unconformably on white, pink, and red clay and fine sand. The 
contact is about 180 feet above sea level. The upper bed is probably the Coharie formation; the lower bed, the McBean.

\section{ALIENDALE COUNTT}

Locality 2.3 miles west of Allendale.-Coarse gray pebbly sand showing incipient red mottling is exposed west of Coosawhatchee Creek (257), 2.3 miles west of Allendale on the road to Woods Crossroads. Gravel in mottled red and gray sand is exposed also 0.7 mile beyond the creek and 0.6 mile northeast of Woods Crossroads. Coarse sand and pebbles in gray clay and patches of gray sandy clay weathering purple crop out on the same road 0.2 mile east of the Augusta road (258) and 7.8 miles southwest of Allendale at an altitude of 200 feet.

Concord Church (259).-Coarse gravel composed of pebbles as much as 3 inches in diameter in mottled gray sandy clay were found at an altitude of 200 to 220 feet at Concord Church, which is on the Augusta road 4 miles east of Johnsons Landing, Savannah River, and 5 miles southwest of Appleton.

Beautiful Gate Church (260).-Gravel underlies the bench at an altitude of 215 feet at the crossroads three-fourths of a mile west of Beautiful Gate Church and 31/4 miles southwest of Appleton.

\section{SUNDERLAND FORMATION}

GENERAL CHARACTER

The name "Sunderland", from a village in Maryland, was first applied to deposits of Pleistocene age by Shattuck ${ }^{41}$ in 1901. As now used it is defined as designating the deposits of Pleistocene age formed while the sea stood about 170 feet higher than it does at the present time. (See pl. 8).

In South Carolina the Sunderland formation consists chiefly of sand and gravel. In general its texture is somewhat finer than that of the Coharie formation, but there is considerable range in size of grain. Unweathered parts are generally gray, but after long exposure to air and circulating water they assume various shades of red and yellow or become mottled.

The formation is nowhere very thick. The measurement of 28 feet at Utsey Bluff, in Dorchester County, is probably not far from the average thickness.

\section{ALLENDALE COUNTY}

Concord Church (261).--On the road to Johnsons Landing, Savannah River, 2.4 miles west of Concord Church, fine mottled red and gray sand and clay containing patches of gravel are probably of Sunderland age.

\footnotetext{
11 Shattuck, G. R., The Pleistocene problem of the North Atlantic Coastal Plain: Johns Hopkins Unir. Circ., vol. 20, p. 74, 1901; Am. Geologist, vol. 28, p. 102, 1901; Maryland Geol. Survey, Pliocene and Pleis tocene, p. 85, 1906.
} 
The deposit is about 8 miles above the entrance to the Savannah River estuary of the Sunderland sea and is 150 feet above sea level.

Duck Creek (262). - A cut at an altitude of 140 feet on the Charleston \& Western Carolina Railway west of Duck Creek and 3.7 miles southeast of Allendale shows about 10 feet of coarse sandy gray clay weathering mottled red and yellow. It passes upward through yellow loam into loose yellow sandy soil.

Barton (263).- Mottled gray and red clayey sand, fine at top, coarser and pebbly below, is exposed on the descent to the Coosawhatchee River 1 mile north of Barton. The upland in this vicinity is 130 to 140 feet above sea level.

Sycamore (264).-About 10 feet of coarse orange to red sand containing patches of gravel is exposed on the north side of Jackson Branch 1.6 miles south of Sycamore on the road to Fairfax. The creek is nearly 110 feet above sea level, and the plain 140 to 150 feet.

Bear Branch (265).--Mottled red and yellow argillaceous sand is exposed on the east side of Bear Branch 2.7 miles southeast of Ulmers on the road to Jennys. The plain south of Bear Branch is slightly less than 160 feet above sea level.

Beech Branch (266).--Fine brick-red sand containing a few small pebbles and lumps of white clay is exposed north of Beech Branch, 2.5 miles south of Barton, at about 120 feet above sea level.

Solomons Crossroads (267.)-About 8 feet of coarse gray pebbly, highly micaceous clayey sand is overlain by 3 feet of loose light-gray sand 2.1 miles northeast of Solomons Crossroads and 3 miles west of Luray.

Solomons Store.--The slope west of Solomons Store (268), 7 miles northwest of Estill, exposes coarse red sand containing angular pebbles. The sand may be older than Pleistocene. It weathers yellow at the top. The 124-foot terrace 1 mile west of Solomons Store is underlain by 6 feet of mottled gray and red sandy loam, beneath which is coarse gray to pink sand with round and subangular pebbles.

\section{BAMBERG COUNTY}

Kirkland Creek.-A low scarp near the 170-foot contour line in the vicinity of Bamberg marks the shore of the old Sunderland sea, but in the western part of Bamberg County the boundary between the Coharie and Sunderland terraces is not conspicuous. A section measured in 1917 on the west side of Kirkland Creek 1/3/4 miles east of Buford Bridge and 51/2 miles south-southeast of Olar, where the upland stands 170 feet above sea level, probably shows the Sunderland formation. 
Section of Sunderland (?) formation at Kirkland Creek (269)

9. Concealed to top of hill; fine gray loamy soil; about

8. Lenses of medium-coarse light-gray sand, fine white sand, and white clayey sand; the coarser parts cross-bedded and generally tinted with pale yellows and pinks_...... 15

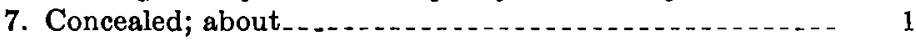

6. Coarse red massive argillaceous sand; about_......... $61 / 2$

5. Fine yellow to orange-colored micaceous argillaceous sand $1 \frac{1}{2}$

4. Coarse pebbly reddish-yellow sand; limonite crusts at

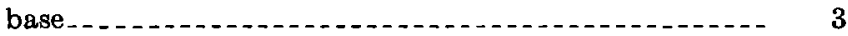

3. Very fine laminated micaceous cohesive orange sand ..... 3

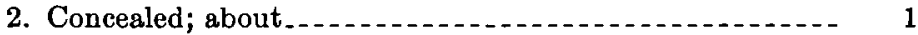

1. Very coarse reddish-yellow sand, perhaps wash; to water

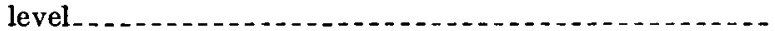

On the east side of the branch the section is more deeply weathered and not so well exposed and its upper part is reddish. A spring issues from the base of the scarp.

\section{COLLETON COUNTY}

Savannah Creek (270).-Coarse and fine gray to reddish sand containing pellets of clay is exposed to a thickness of about 10 feet at the crossing of Savannah Creek 0.3 mile west of Wesley Chapel, near the northwest corner of Colleton County.

\section{DORCHESTER COUNTY}

Utsey Bluff (164).-At Utsey Bluff, on the Edisto River 1 mile west of Cattle Creek and 5 miles southwest of Reevesville, recent landslides exposed, in 1928, 28 feet of coarse gray sand enclosing pellets of gray clay, which passes below into fine sticky sand that rests upon the Cooper marl. The plain at the top of the bluff stands. 115 feet above sea level.

\section{CALBOUN COUNTY}

Lonestar (271). - A railroad cut 1 mile east of Lonestar at about. 150 feet above sea level shows coarse gray sand in clay that is mottled. pink below and yellow in the upper part. It was probably deposited in an estuary of the Sunderland sea.

\section{ORANGEBURG COUNTY}

Parler (272).-Fine gray tough argillaceous sand is exposed at an altitude of 140 feet at the top of a hill on the River Road west of Chapel Branch, 1.2 miles east of Parler.

\section{CLARENDON COUNTY}

As the Sunderland formation closely resembles certain facies of the Black Mingo formation, which underlies nearly all of Clarendon County, some of the outcrops described below may be of Eocene age rather than Pleistocene. 
Santee River road.-On Taw Caw Creek (273) at the Santee River road, 6 miles south-southeast of Summerton, about 6 feet of tough gray sandy clay is underlain by about 15 feet of coarse cross-bedded orange sand with gravel at the base.

A section measured on the east side of Wyboo Swamp at Wyboo Church $(84,137), 11$ miles south of Manning, is shown on page 79.

About 15 feet of coarse gray and red sand and gravel containing thin beds and laminae of gray plastic clay underlies the flat-topped hill west of Church Branch and 1 mile east of Wyboo Church. The hill is between 120 and 130 feet above sea level.

The Santee River road between Church Branch and Mill Branch, in the southeastern part of Clarendon County, crosses deep sand that apparently was once the sandy coast of the Wicomico sea. The scarp separating the Sunderland terrace from the Wicomico terrace passes northward from a point about three-quarters of a mile east of Mill Branch at the river road.

Fellowship Branch (274).--About 20 feet of coarse gray and red sand and gravel extends from a few feet above water in Fellowship Branch, 21/2 miles southwest of Manning, to the level of the plain at an altitude of 120 feet.

Ox Swamp (275).-On the road to Davis station 2.7 miles south of the courthouse at Manning, on the east side of Ox Swamp, 15 feet of coarse gray to red gravel (altitude 120 feet at top) overlies 5 feet of greenish-red clay and red sand that presumably belong to the Black Mingo formation.

Manning (81).-Dark shale of the Black Mingo formation exposed in a drainage ditch southeast of Manning is overlain by 10 feet of tough gray coarse sand and gravel that are probably of Sunderland age.

Trinity Church (276).-Fine gray sandy clay is exposed in a ditch at an altitude of about 120 feet a quarter of a mile northeast of Trinity Church, 4 miles north of Manning.

Tearcoat Branch (277). - On Tearcoat Branch at Westminster Church, 9.2 miles north of Manning, coarse gray sand and gravel, becoming finer above, weather reddish yellow.

Gailliard Crossing (297).- On the east side of Black River Swamp at Gailliard Crossing about 15 feet of coarse white and variegated sand exposed on the slope above a flowing well at a slightly higher altitude than the Wicomico terrace may be of Sunderland age.

\section{SUMTER COUNTY}

Near Mayesville.-Fine gray sandy clay is exposed on the ascent from Scape Oer Swamp 1 mile southwest of Mayesville (278). Hard white, yellow, or red sand containing a few dark specks is exposed 
on the descent to Rocky Bluff Swamp 6 miles northeast of Sumter on the road to Mayesville (279). This swamp is 114 feet above sea level; the upland, 145 feet.

Oswego.-The plain near Oswego (altitude 157 feet) is underlain by coarse red argillaceous sand with a ledge of hard red ironstone near the top, as shown by exposures along Cow Pen Swamp.

Pocalla Springs (91).- About 20 feet of sand is exposed along the road at Pocalla Springs, 3 miles south of Sumter. The lower part is fine sand interbedded with coarse sand, laminated, gray and red; the upper part is coarse and cross-bedded and contains some gravel.

LEE COUNTY

Atkins (280).-Medium-coarse yellow sand is exposed about 155 feet above sea level in a drainage ditch 1.3 miles southwest of Atkins on the road to Mayesville.

Black River (281).--About 6 feet of coarse yellow sand and gravel is exposed at the crossing of the Black River 2 miles northeast of Mayesville on the road to Atkins. The swamp is between 110 and 120 feet above sea level; the upland, about 140 feet.

\section{DARLINGTON COUNTY}

McCowans Mill (282).-A cut on the road south of McCowans Mill, 3 miles northwest of Darlington, exposes about 25 feet of tough light-gray sandy clay, faintly mottled with pink, overlain by coarse gray argillaceous sand passing into yellow sandy clay at top. When examined in 1922, the road appeared to have been recently graded, and the sand was less weathered tban most exposures of the Pleistocene deposits. The plain is probably between 160 and 170 feet above sea level.

Darlington (283).-The following section is exposed on the Hartsville road at a branch of Swift Creek on the west edge of Darlington:

\section{Section at Darlington}

Sunderland formation (Pleistocene):

Feet

2. Coarse gravelly reddish-yellow sand; pebbles all angular or very slightly rounded; about........... 10

Unconformity.

Black Creek (?) formation (Upper Cretaceous?):

1. Fine laminated yellow sand; about

The plain nearby is about 160 feet above sea level.

Cashua Ferry (20).-At the Pee Dee River bluff on the road from Darlington to Cashua Ferry the Black Creek formation is overlain by 35 feet of coarse pebbly compact sand that passes upward into finer sand laminated with clay. The color ranges from reddish yellow to red and gray. The plain at the top is about 165 feet above sea level. A section at this place is given on page 27 . 
FLORENCE COUNTY

Effingham (284).-The following section is exposed on the descent to a small branch on the Florence road 1.2 miles northwest of Effingham:

\section{Section 1.2 miles northwest of Effingham}

Pleistocene (Sunderland or Wicomico formation): Feet

2. Coarse dirty brownish sand; to top of hill about 100 feet above sea level ............................

Unconformity.

Upper Cretaceous (?) (possibly Pleistocene):

1. Dark blue-gray sand and clay below, passing upward into light-gray, nearly white clay _._._. 5

Laurance Bridge (38).-At Laurance Bridge over the Lynches River at the mouth of Sparrow Swamp the following section is exposed:

\section{Section of Sunderland (?) formation at Laurance Bridge}

3. Coarse brown sand to plain about 105 feet above sea level_ 15

2. Light-gray and pink coarse sand and sandy clay, about...- 10

1. Concealed to water level in the Lynches River at stage of 8.3 feet at Effingham............................ 15

Sloan ${ }^{42}$ reports on the river bank 3 feet of smooth black laminated shale overlying 4 feet of gray-green granular to smooth-textured marl with indurated layers, which contain Exogyra costata, Anomia simplex, and other Cretaceous fossils. This outcrop of the Peedee formation was probably under water when the preceding section was measured.

Big Branch (285).-About 15 feet of light-gray clay, fine yellow sand, and coarse yellow sand are exposed on the descent to Big Branch 0.4 mile northeast of Elim. The materials change rapidly laterally and vertically and show several unconformable contacts, but all appear to belong to one formation.

Cartersville.-The 22-foot bluff east of Durants Bridge over the Lynches River near Cartersville, about 145 feet above sea level, consists of medium-fine gray compact sand weathering red and yellow.

Timmonsville.-On both sides of Sparrow Swamp (286) 11/2 miles west of Timmonsville are exposures of about 25 feet of sand. At the base it is tough, coarse, and gray and contains lenses of gray sandy clay; at the top it is coarse and white, buff, or yellow. The plain is about 150 feet above sea level.

On the Timmonsville-Lydia road 0.4 mile north of the Atlantic Coast Line Railroad (287), coarse pinkish angular cross-bedded sand is exposed on the descent to a small branch. The altitude is about 160 feet. 
Middle Swamp (288).-Coarse reddish sand is exposed on the slope to Middle Swamp on the Timmonsville-Darlington road near the county line. The upland is about 150 feet above sea level, and the creek about 130 feet.

Florence.-Palmetto Street in Florence, as shown by excavations for a sewer, is underlain by 10 feet of tough gray sandy clay. Reddish sand is exposed at an altitude of about 145 feet 3 miles northeast of Florence.

High Hill Creek (22).-At High Hill Creek on the road from Florence to Darlington about 15 feet of terrace deposits overlie the Black Creek formation. They consist of coarse yellow sand and gravel at the base but become finer above and pass into very fine white sand or silt at the top.

MARION COUNTY

Little Pee Dee River.-On the hillside leading down to the Little Pee Dee River on the road from Mullins to Nichols there is an exposure of sand and clay. Most of the sand is fine, but it includes a little weathered arkosic gravel near the bottom. The prevailing color of the sand is orange-yellow, but some of it is red. The clay is chiefly gray streaked with pink or purple. The upland plain is about 100 feet above sea level, and the lower terrace about 55 feet.

\section{DILLON COUNTY}

Little Pee Dee River (1).-A section showing 15 feet of Sunderland beds on the edge of the swamp of the Little Pee Dee River 1 1/2 miles east-southeast of Dillon is given on page 19.

\section{MARLBORO COUNTY}

Blenheim (289).--The following section was observed in 1917 on the descent to Three Creeks half a mile south of Blenheim:

Section at Blenheim

Sunderland formation (Pleistocene):

3. Covered to top of hill, about 120 feet above sea level -

Feet

2. Coarse reddish sand and gravel containing well-rounded quartzite pebbles as much as 2 inches in diameter and, in the upper part, masses of ferruginous sandstone.

Tuscaloosa (?) formation (Upper Cretaceous or possibly Pleistocene):

1. Tough blue-gray sandy clay containing a few small round transparent quartz pebbles; obscure crossbedding in places, elsewhere massive

Bristow (290). - At a branch 1 mile north of Bristow the plain about 115 feet above sea level is underlain by coarse gray to red pebbly sand. 
Hagins Prong and Cottingham Creek.-Gravel is exposed on Hagins Prong 2 miles southwest of Clio (291) and at Dunbar (292), also on Cottingbam Creek about 3 miles east of Bennettsville (293). The altitude of both of these streams at these places is about 130 feet.

\section{WICOMICO FORMATION}

GENERAL CHARACTER

The Wicomico formation, named from a river in southern Maryland, was first described by Shattuck. ${ }^{43}$ As there is some doubt as to its original type locality, I redefined the Wicomico in $1930^{44}$ as the terrace (and formation) corresponding to a shore line about 95 (now thought to be nearer 100) feet above sea level. (See pl. 7.) The Wicomico formation therefore includes the deposits formed while the sea stood about 100 feet higher than its present level.

The Wicomico consists chiefly of fine sand but includes some clay, coarse sand, and gravel. The deposits formed in estuaries tend to be coarser than those laid down in the open sea and contain more gravel. The formation is nowhere very thick. It probably exceeds 50 feet in thickness at few places and may average less than 25 feet.

JASPER COUNTY

Gillisonville (294).-About 20 feet of fine, well-rounded light-gray sand is exposed on the descent to Bay Swamp, a tributary of the Coosawhatchee River, three-quarters of a mile northeast of Gillisonville. The sand contains sufficient clay to make a plastic mixture, which weathers yellow, orange, or red. It is overlain by loose gray residual sand that underlies the Wicomico plain at an altitude of 70 to 80 feet. Springs issue from the base of the exposed beds.

\section{COLLETON COUNTY}

Walterboro (295).-About 10 feet of massive hard argillaceous micaceous sand is exposed on the Bell road just northwest of the city limits of Walterboro at the descent to the swamp of Ireland Creek. The sand appears to have been originally gray, but it is now mottled with brick red and grades upward through orange into pale yellow or gray at the surface. The prevailing color is red. As the creek lies 40 feet or more below the level of the surrounding upland (Wicomico terrace), it has probably cut through the terrace deposits into the underlying Miocene Hawthorn formation, and the sand exposed may be Hawthorn.

Raysor Bridge (166).-A section showing 29 feet of sand and clay referred to the Wicomico formation is included in the description of the Raysor marl (p. 116).

\footnotetext{
4a Shattuck, G. B., The Pleistocene problem of the North Atlantic Coastal Plain: Johns Hopkins Univ. Circ., vol. 20, p. 74, 1901; Am. Geologist, vol. 28, p. 103, 1901; Maryland Geol. Survey, Pliocene and Pleistocene, p. 92, 1806.

4 Cooke, C. W., Correlation of coastal terraces: Jour. Geology, vol. 38, p. 582, 1930.
} 
Target Swamp (296).-A drainage ditch near Target Swamp on the State Road 23/4 miles northwest of Holly Hill shows 8 feet of light-gray sandy clay that is somewhat mottled with red and passes into light sandy soil. The surface is about 100 feet above sea level.

\section{BERKELEY COUNTY}

Santee Canal.-The old Santee Canal, which connected the Cooper River with the Santee River by way of Biggin Swamp and a cut about 4 miles west of Pineville, crosses a flat divide about 80 feet above sea level. The divide is underlain by coarse mottled or red sand and gravel.

CLARENDON COUNTY

Gailliard Crossing (297).-About 15 feet of hard gray gravel exposed at an altitude of somewhat less than 100 feet on the descent to the Black River Swamp at Gailliard Crossing, 11/2 miles south of Gable, probably represents a deposit formed at the mouth of the river during Wicomico time.

Deep Creek (80).-Coarse gray and reddish to yellow sand containing reworked fragments of Black Mingo fossils and unconformably overlying the Black Mingo formation (here consisting of fine gray laminated sand containing patches of siliceous shell rock) is exposed on the west side of Deep Creek on the Kingstree road 5 miles east of Manning. The sand, which underlies a terrace between 90 and 100 feet above sea level, was probably deposited in a bay or estuary of the Wicomico sea.

\section{FLORENCE COUNTY}

Lynches River (220).--In the 25-foot bluff on the east side of the Lynches River at Anderson Bridge, 7 miles west of Pamplico, there are poor exposures of tough gray argillaceous sand, streaked and mottled with red. Low water in the river is about 70 feet above sea level.

Forestville (298).- - Road cuts about 80 feet above sea level 1 mile south of Forestville and 23/4 miles northeast of Pamplico expose yellow sand.

Pee Dee River.-At Davis Landing (36), on the Pee Dee River 3 miles northwest of Poston, 17 feet of laminated greenish-gray plastic clay containing laminae of sand and about 3 inches of fine yellow glauconitic sand at the base overlies the Miocene Duplin marl. The contact between the marl and the sand is sharp. The section is described more fully on page 120 . 
The following section is exposed at Myers Landing, $4 \frac{1}{2}$ miles southeast of Pamplico:

Section at Myers Landing, Pee Dee River (221)

Wicomico (?) formation (Pleistocene): Feet

4. Yellow loam, about ...... 3

3. Chocolate-colored sandy clay, about._._......... 10

2. Yellow and red sand, about

Duplin marl (Miocene):

1. Soft gray to yellow sandy calcareous marl containing fragments of Amusium mortoni, Ostrea sp., and Pecten sp...........

The following section was noted in 1917 at Dewitts Landing, on the Pee Dee River 3 miles east of Pamplico:

Section of Wicomico (?) formation at Dewitts Landing (34)

4. White and yellow fine sand and gravel containing laminae of purple or greenish clay; to top of bluff

3. Loose lemon-yellow cross-bedded sand containing a little

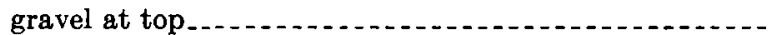

2. Jet-black sand composed of grains of colorless quartz coated with a black substance.....................

1. Concealed to high-water level; compact dark-gray clay of the Upper Cretaceous Peedee formation is exposed at lower stages.

Sloan ${ }^{45}$ records a somewhat different sequence at this place. His section, as adapted, is as follows:

\section{Section at Dewitts Landing}

Wicomico (?) formation (Pleistocene):

9. Sand and red-clay loam

8. Sand enclosing pebbles half an inch and less in diameter....... 2.3

7. Sand ............. 3

6. Laminated white, pink, and red clay in horizontal layers........... 6

5. White, yellow, black, and brown stratified sand..... 9

4. Ferruginous sandstone ...

3. Purple and white mottled clay

Peedee formation (Upper Cretaceous) :

2. Gray marl._. 47

1. Blue-black marl enclosing Exogyra costata. etc....... 9

According to Sloan, the altitude of the top of Dewitts Bluff is 66 feet above mean low tide. The Pleistocene deposits there may

4 Sloan, Earle, op. cit. (Catalogue), p. 314. 
accordingly represent the Penholoway formation rather than the Wicomico.

The Pleistocene deposits at Mars Bluff (26), on the Pee Dee River east of Florence, were described in 1906 by L. W. Stephenson, on whose field notes the following partial section of the bluff is based:

Section of Wicomico formation at Mars Bluff (26)

3. Hard yellowish sandy loam grading down through Ft. in. mottled red to red sandy clay, and this, in turn, into coarse red sand at base.................... 10

2. Light-drab clay stained with iron rust at top; about _- 8

1. At base of clay, a thin band of small pebbles less than 1 inch in diameter, whose surface undulates along the cliff. Lies unconformably upon the Upper Cretaceous Black Creek formation, about 35 feet above the river. . . 6-10

A little farther downstream there is a 3- to 4 -foot lens of stratified reddish sand near the base of bed 2, showing that the materials vary within short distances.

\section{MARION COUNTY}

Marion.-The Wicomico terrace in the vicinity of the cemetery $1 \frac{1}{2}$ miles northeast of Marion on the road to Mullins is underlain to a depth of 8 or 10 feet by gray argillaceous sand that weathers red.

Marion-Sellers road.-An excavation for road metal 4.6 miles from Sellers exposed in 1917 about 8 feet of coarse sand and gravel that became finer above, overlain by about 3 feet of sandy soil. The pebbles, which are chiefly of quartz, are subangular. Their longest diameter averages somewhat more than half an inch. This deposit is probably either of Penholoway or Wicomico age.

Ariels Crossroads (299).- The following section is exposed on the road to Galizants Ferry near Ariels Crossroads:

\section{Section at Ariels Crossroads}

Wicomico (?) formation (Pleistocene):

2. Coarse gray sand and angular gravel containing fragments of fine sandy clay apparently derived from the underlying bed; estimated........................

Black Creek (?) formation (Upper Cretaceous?):

1. Fine gray laminated sand and clay, weathered red at top; estimated. .......

Nichols.-A steep escarpment on the road to Mullins 0.4 mile from Nichols shows the following sequence of strata:

\section{Section of Wicomico formation at Nichols}

4. Yellow to orange sand containing flakes of gray clay.

3. Ferruginous gravel bed about 1 foot thick.

2. Light-gray sand and clay.

1. Sticky gray clayey sand and pebbles. 
The altitude of the top of the bluff is about 90 feet; that of the base, about 55 feet.

Mullins-Smithboro road (29).--The following section was observed on the road to Mullins at a branch of Buck Swamp 3 miles southeast of Smithboro. The water in the creek stands about 80 feet above sea level.

\section{Section 3 miles southeast of Smithboro}

Sunderland or Wicomico formation (Pleistocene):

3. Fine sandy soil

Feet

2. Gray sand and gravel weathering red; pebbles in lower part as much as three-quarters of an inch long.-..Unconformity.

Black Creek formation, Snow Hill marl member (Upper Cretaceous):

1. Very fine blue sand containing impressions of shells; exposed in the bed of the creek at an old mill......

\section{DILLON COUNTY}

Dunbarton Bridge (300).-During Wicomico time the valleys of the Lumber River, Little Pee Dee River, and Buck Swamp were occupied by estuaries. The following section was measured at Dunbarton Bridge on Buck Swamp, on the road to Marion 1 mile south of Floyd Dale:

\section{Section at Dunbarton Bridge}

Wicomico formation (Pleistocene):

Feet

5. Fine yellow sandy loam; to surface at about 85 feet above sea level....................................

4. Coarse pink to gray cross-bedded sand and gravel, becoming finer toward the top and merging into bed 5; the pebbles consist of rounded or subangular grains of quartz that average less than half an inch in diameter

Unconformity (?).

Black Creek (?) formation (Upper Cretaceous ?):

3. Fine laminated gray to red sand..................

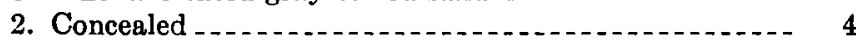

1. Covered by sand and mud of Recent swamp deposit; to water level

PENHOLOWAY FORMATION

DEFINITION

The Penholoway formation may be defined as the deposits laid down in the sea and its estuaries when the sea stood about 70 feet above its present level. The name is taken from Penholoway Creek and Penholoway Bay, in Brantley County, Ga., northeast of Hortense, and was first applied to the terrace that is well developed there. ${ }^{46}$

\footnotetext{
16 Cooke, C. W., Physical geography of Georgia: Georgia Geol. Survey Bull. 42, p. 24, 1825; Seven coasta] terraces in the Southeastern States: Washington Acad. Scl. Jour., vol. 21, p. 509, 1931.
} 
The location of the Penholoway shore line in South Carolina is shown in plate 6 .

\author{
DORCHESTER COUNTY
}

Givhans Bridge (170).-At Givhans Bridge, on the Edisto River 6 miles southwest of Ridgeville, the Miocene Duplin marl is overlain by about 15 feet of fine brown sand and clay.

Givhans (301).-About 10 feet of fine mottled gray and brick-red sand is exposed on a slope about half a mile east of Givhans, $3 \frac{1}{2}$ miles east of Givhans Bridge.

Four Hole Swamp (169).- - The following section of Eocene and Pleistocene strata was noted in 1925 on the Orangeburg road (State Highway 2) at the crossing of Four Hole Swamp, 2.7 miles east of Dorchester:

\title{
Section on Four Hole Swamp
}

Penholoway (?) formation (Pleistocene):

3. Fine white cross-bedded sand weathering yellow (beach or river deposit); to top of hill at altitude of 85 feet above sea level.................... 15

2. Dark-gray pebbly sand at base, passing upward into Unconformity. fine black carbonaceous sand ................. $41 \frac{1}{2}$

Cooper marl (Eocene):

1. Soft brown granular marl containing shark teeth, casts of corals and mollusks, Pecten calvatus Morton, Terebratulina sp., and many phosphatic nodules_._ 23

Bed 3 of this section appears to represent a beach or river deposit built upon the tidal marsh of an estuary of the Penholoway sea in which high tide stood very nearly 70 feet above the present mean sea level.

\section{WILLIAMSBURG COUNTY}

Suttons.-About 15 feet of coarse gravel passing upward into sandy loam overlies the Santee limestone at Parson's mill, at Suttons.

FLORENCE COUNTY

Johnsonville (302).-All the strata exposed near Johnsons Bridge appear to be marine Pleistocene deposits. The lower part consists of plastic brown laminated sandy clay; the upper part is mostly sand. Johnsonville is about 93 feet above sea level. Although the ridge on which the town stands is high enough to be of Wicomico age, it appears to be an island built in the Penholoway sea.

TALBOT FORMATION

The Talbot formation, named in 1901 by Shattuck ${ }^{47}$ from Talbot County, Md., consists of the deposits laid down in the Talbot sea, whose abandoned shore line stands about 42 feet above present sea

47 Shattuck, G. B., The Pleistocene problem of the North Atlantic Coastal Plain: Johns Hopkins Univ. Circ., vol. 20, p. 74, 1901; Am. Geologist, vol. 28, p. 104, 1901. 
level. As first described, the formation was supposed to include all the late Pleistocene deposits between the Talbot strand line and the present seashore, but the subsequent discovery of an intermediate strand line makes it necessary to restrict the Talbot formation to the older of the two divisions now recognized. As thus restricted the Talbot is equivalent to the TChowan formation of North Carolina, and its name has priority over +"Chowan."

In South Carolina the greater part of the Talbot seems to have been formed in bays and drowned river valleys, many of which were separated from the open ocean by narrow barrier ridges. (See pls. 1 and 5.)

Much of the Talbot formation consists of very fine gray to red or pink thin-bedded sand and clay. There are many exposures of material of this kind along United States Highway 52 in the southern part of Berkeley County.

\section{Pamuico formation}

general Character

The Pamlico formation includes the deposits that accumulated when the sea stood about 25 feet above its present level. The formation, therefore, nearly everywhere lies less than 25 feet above sea level, but it reaches nearly 50 feet in old beach ridges in Horry County. The distribution of the formation in South Carolina is shown on plate 1 , and its shore line in plate 4 . The name, derived from Pamlico sound, was first applied to it by Stephenson ${ }^{48}$ in 1912 . Althougb Stephenson did not specifically correlate the Pamlico sea with the abandoned shore line at 25 feet, it is evident that such was his intention.

The Pamlico formation consists chiefly of fine sand and blue or gray clay. Clay predominates in the lower part of the formation, especially in Beaufort County, where there is 20 or 30 feet of it. Very fine white, yellow, or gray sand composed chiefly of quartz but including a little mica and a few black grains generally makes up the upper part of the formation. These two parts are not everywhere distinct but generally intergrade. The clay is commonly somewhat sandy, and the sand at some places contains enough clay to make it sticky or coherent. The thickness of the formation, as indicated by well logs, is about 60 feet.

Many fossil shells have been found in the Pamlico formation. Pugh ${ }^{49}$ lists 179 species, most of which were collected at Simmons Bluff on Yonges Island or on the Stono River. Most of the fossils are marine mollusks that inhabit the littoral zone along the Carolinas today. They indicate that the temperature of the water in which

48 Stephenson, L. W., North Carolina Geol. and Econ. Survey, vol. 3, p. 286, 1912.

10 Pugh, G. T., Pleistocene deposits of South Carolina, pp. 44-51, Nashville, Tenn., 1905. 
they lived was either about the same as that which now prevails there or slightly warmer, ${ }^{50}$ and thus that the Pamlico formation was deposited during an interglacial stage.

\section{BEAUFORT COUNTY}

Port Royal (303).-A group of six wells, drilled in 1919 for the United States Navy Department along the railroad right-of-way $1 \frac{1 / 4}{4}$ miles above Port Royal, penetrated through the Pleistocene deposits and found water in the Cooper marl. The depths given in the following combined log of the six wells show the least depth of the top and the greatest depth of the bottom of each bed.

Log of six wells $1 \frac{1 / 4}{4}$ miles above Port Royal

\begin{tabular}{|c|c|c|}
\hline & $\begin{array}{c}\text { Thickness } \\
\text { (feet) }\end{array}$ & $\begin{array}{l}\text { Depth } \\
\text { (feet) }\end{array}$ \\
\hline $\begin{array}{l}\text { Pamlico formation (Pleistocene): } \\
\text { 4. Fine yellow, brown, or white sand } \\
\text { 3. Dark-gray sandy clay or clayey sand containing well-preserved shells } \\
\text { Miocene (?) (Hawthorn (?) formation): } \\
\text { 2. Gray sand, phosphate rock, pebbles; residual from Hawthorn, possibly } \\
\text { reworked into Pleistocene.. } \\
\text { Cooper marl (Eocene) : } \\
\text { 1. Gray to white limestone containing Otionella cava, Periarchus, Pecten } \\
\text { membranosws, and other fossils. to bottom of wells. }\end{array}$ & $\begin{array}{r}30-32 \\
10-26 \\
4-20 \\
45-60\end{array}$ & $\begin{array}{c}0-32 \\
30-58 \\
40-62 \\
52-120\end{array}$ \\
\hline
\end{tabular}

The evenness of the top and the irregularity of the bottom of bed 3 indicate that it is probably conformable with the overlying bed and unconformable with the underlying bed, and the lack of coarse material above it and the conspicuous difference in the material of the underlying bed confirm this supposition. The top of the Cooper marl, with a range in depth of about 10 feet, appears to be less irregular than the top of the overlying phosphatic bed, with a range of about 18 feet; but the unevenness of these surfaces may not be as great as is indicated by the depths at which the changes were detected in the cuttings. The ground at these wells is somewhat more than 20 feet above sea level.

Parris Island (304).-A group of five wells ranging in depth from 101 to 108 feet was drilled in 1917 on Parris Island 1/2 miles west of the United States naval station. Cuttings from these wells are not available for study, but the driller's logs indicate that the sequence penetrated is about as follows:

\section{Log of five wells on Parris Island}

Pamlico formation (Pleistocene): Feet

4. Yellow and gray sand ..................... $0-20$

3. Dark-bluish sandy clay and shells.............. 20-50

Hawthorn formation (Miocene):

2. Tough gray sandy marl _............ $50-80$

Cooper marl (Eocene):

1. Gray to white limestone with shells; to bottom _... 80-108

so Pugh, G. T., Pleistocene deposits of South Carolins, p. 66, Nashville, Tenn., 1905. 
The ground at these wells is more than 10 feet and less than 20 feet above sea level, and the top of the clayey shell bed of the Pamlico formation is at about the same level on Parris Island as on the mainland near Port Royal, 3 miles farther north. All the driller's logs report 10 feet of "soft grayish rock" at the base of what is here called "Hawthorn formation." This soft rock may represent the Cooper marl rather than the Hawthorn.

Frogmore (305).-A well drilled in 1905 to a depth of 960 feet at the Penn Normal, Industrial, and Agricultural School at Frogmore, St. Helena Island, passed through 40 feet of fine brownish and lightgray sand and 22 feet of dark-gray calcareous clay, somewhat sandy at the base (Pamlico formation), and entered the Eocene Cooper marl at a depth of 62 feet. The clay contains well-preserved Pleistocene shells. No trace of the Hawthorn formation was discovered in the cuttings from this well.

\section{CHARLESTON COUNTY}

Johns Island (215).-According to Sloan, ${ }^{51}$ from whose report the following section is adapted, a bed of Pleistocene shells overlies the phosphate rock at the old Bolton mines, 0.3 mile south of Johns Island station.

\section{Section at old Bolton mines, Johns Island}

Recent:

5. Vegetable muck.

Pleistocene (Pamlico formation):

4. Green glauconitic clay-sand ( + Bohicket phase of Sloan) - 5

3. Sand (†Bohicket phase of Sloan) _._.

2. Pleistocene shells (†Wadmalaw phase of Sloan) $\ldots \ldots \ldots 2$

Miocene (Hawthorn formation):

1. Phosphate rock (†Edisto phase of Sloan)

Sloan also reports the †Bohicket and †Wadmalaw "phases", without shells, at the St. Andrews mine 0.3 mile southwest of Johns Island.

Charleston.-The city of Charleston is underlain by Pleistocene deposits to a depth of about 50 feet below sea level. The log of the deep well of the Charleston Consolidated Railway \& Lighting Co., drilled in 1911 on made land at the gas works, at the foot of Charlotte Street, near the Cooper River, ${ }^{52}$ reports 2 feet of very coarse quartz sand and shells at the base of the Pleistocene at a depth of 56 feet below the surface, overlain by 44 feet of material consisting chiefly of dark-gray micaceous clay and shells. These two beds may represent the Pamlico formation or they may represent an older Pleistocene formation. The $\log$ of a well recorded by Tuomey ${ }^{53}$ shows sand

sl Sloan, Earle, op. cit. (Catalog), p. 298.

32 Stephenson, L. W., A deep well at Charleston, 8. C.: U. S. Geol. Survey Prol. Paper 90, pp. 69-94, 1914.

ss Tuomey, Michael, op. cit., p. 187. 
underlain at a depth of 17 or 18 feet by a 2-foot bed of gravel and oysters, which may mark the base of the Pamlico formation.

Simmons Bluff (306).--According to unpublished notes of Frank Burns, Simmons Bluff, on Wadmalaw Sound near Yonges Island, is about half a mile long and ranges in height from 5 feet above hightide mark at the west end to 23 feet at the east end. Tuomey ${ }^{64}$ gives the following section:

Section of Pamlico formation at Simmons Bluff, Yonges Island [Adspted from Tuomey]

Feet

4. Sand ... . .

3. Red loam containing casts of shells $\ldots$

2. Clay; base at high-tide level .

1. Fossiliferous bed, composed of sand and comminuted shells.

Fossils in fine state of preservation................ 4

Half a mile north of the railroad terminal at Yonges Island the bluff is only 13 feet above mean tide level. Fine blue to yellow, somewhat sticky sand containing many well-preserved shells is exposed on the beach between high and low tides. It is overlain in a vertical bluff by light-yellow fine sand containing enough clay to make it coherent. At the top of the bluff is about 5 feet of similar but loose sand. All the beds contain some mica and small black particles.

\section{GEORGETOWN CODNTY}

Laurel Hill (307).-Tuomey ${ }^{55}$ describes as follows the conditions at Laurel Hill Bluff, on the south side of the Waccamaw River about $13 \frac{3}{4}$ miles south of the Horry County line. The deposit presumably represents the Pamlico formation, but it may be of Talbot age.

In All Saints, Georgetown district, I saw on the mainland beds of oysters and other shells belonging to this [post-Pliocene] formation. But one of the most interesting localities is that at Laurel Hill Bluff, on the Waccamaw side of the peninsula, where the river, by encroachment, has produced a perpendicular bluff 30 feet in height, composed principally of yellow sand. At the base a bed about 8 feet thick is exposed, which is made up of sand and broken shells. At first sight it had the appearance of being thrown up by the waves into its present elevation; but a bed of blue mud, which I found overlying the shells, convinced me that its surface was once at the level of tide and that its present position 8 feet above it is the result of a regular uplift and not the effect of waves. This is the highest elevation at which I have seen the fossiliferous bed of the postPliocene of the State.

The fossils that I found here are Arca ponderosa, A. pexata, Mactra lateralis, $M$. similis, Oliva litterata, Donax variabilis, and Gnathodon cuneatum.

" Tuomey, Michael op. cit., p. 189.

s Idem, pp. 187-188. 
Fairfield, Santee River (308).--Tuomey continues as follows:

There are other localities around Georgetown, and fossil shells of the formation have been met with during the excavation of the Winyah Canal, showing that this region is underlaid by it. It is exposed on the Santee, below Mazyck's [Lynches'] Ferry at Fairfield. The bed at this place must correspond with the stiff blue clay that is penetrated in the wells at Charleston. It is a tenacious and compact clay, containing but few fossils and those always with the valves united. Mactra lateralis and Pinna seminuda were among the most conspicuous.

Georgetown.-The Pamlico plain west of Georgetown is underlain by 10 feet or more of fine gray to yellow sand. Exposures were noted on the west bank of Ports Creek 6 miles west of Georgetown (309) and on the Andrews road 12.6 miles from Andrews.

HORRY COUNTY

Red Hill (310).-At the forks of the roads to Myrtle Beach and Little River 2.1 miles southeast of Conway coarse sand and gravel alternating with fine laminated sand are exposed along the highway and in a cut on the Atlantic Coast Line Railroad. The color ranges from gray to red. Most of the pebbles are subangular.

Red Hill is at the inner edge of an upland that seems to have grown seaward by the accretion of beach ridge after beach ridge. (See pl. 17.) Where crossed by the railroad, the altitude of the upland ranges from 45 feet at the northwest to 35 feet near Pine Island, where the upland adjoins a lower plain 23 feet above sea level. Although the northwestern part of the upland stands about 3 feet higher than the shore of the Talbot sea and the southeastern part 10 feet higher than the Pamlico shore, it seems likely that the entire upland was built up by waves and winds during Pamlico time. That it was built by accretion becomes evident on studying a mosaic of aerial photographs of the region (pl. 17).

Myrtle Beach (311).-A kind of coquina composed of shell fragments and coarse sand and gravel cemented together crops out on the strand near Myrtle Beach. Brown sand containing well-rounded or flattened pebbles has been cut into by the waves at the main road leading to the beach. This deposit is probably the Pamlico formation. About 5 feet of it is exposed. Similar coquina is reported by Tuomey from the beach not far from Prices Creek.

Bucksport (312).- Shells of the common oyster (Ostrea virginica Gmelin) embedded in fine blue-gray sticky sand were found in 1917 at the bottom of a 6-foot ditch on the land of D. V. Richardson about 1 mile southwest of Bucksport. They retain much of the original organic color and luster and are probably not older than Pleistocene. The bed containing them is probably part of the Pamlico formation. 
White Point Creek (313).-White Point Creek, one branch of which has its source in Price Swamp, about midway between Myrtle Beach and the North Carolina line, is probably the stream referred to by Tuomey ${ }^{58}$ as follows:

On Price's Creek, not far from this locality, a bed of loose, disconnected valves of shells occurs, which is 6 feet thick. The shells are not waterworn but resemble the beds of shells thrown up by storms on the shore. It is about half a mile from the beach and is elevated above tide 5 feet. The shells are principally Venus mercenaria, Ostrea virginiana, and Arca incongrua. I saw also among them a West Indian Arca and a species of Pectunculus.

About 5 feet of coquina containing oysters and other bivalves is exposed on the north side of White Point Creek on United States Highway 17.

\section{GEOLOGIC HISTORY}

Little definite information is available concerning the condition of the area now included within the Coastal Plain of South Carolina during the long periods of time preceding the Upper Cretaceous. For many ages the region was probably land, forming part of the ancient continent of Appalachia, whose eastern shore may have lain along the outer edge of the present Continental Shelf. During the Triassic period this land area seems to have been shattered by faults and intruded by basic lava, for diabase and red shale like that of the Newark group of the Middle Atlantic States have been found beneath the deposits of the Coastal Plain in a deep well at Summerville. (See p. 177.) Recent movements along one of these Triassic (?) faults may have been the cause of the destructive Charleston earthquake of 1886 and of the frequent tremors to which the region around Summerville is subject.

The end of Lower Cretaceous time probably found this part of North America reduced to a nearly level plain covered by a thick mantle of decomposed rocks. Then came a continental warping that domed up the region now occupied by the Appalachian Mountains and tilted down the land lying east, south, and southwest of it, so that the sea crept up upon the margin of the continent, possibly as far as the present Fall Line. It is not known whether the earliest Upper Cretaceous sediments (Tuscaloosa formation) are marine or continental. If they are marine the seashore then extended across South Carolina and Georgia approximately parallel to the present coast, circled across the northeastern part of Alabama, and ran northward across western Tennessee and Kentucky to the head of the Mississippi Embayment.

The tilting that submerged the margin of the continent raised the western part of the Piedmont and increased its slope to the sea. The streams flowed faster and began to cut into the cover of residual

ss Tuomey, Michael, op. cit., p. 187. 


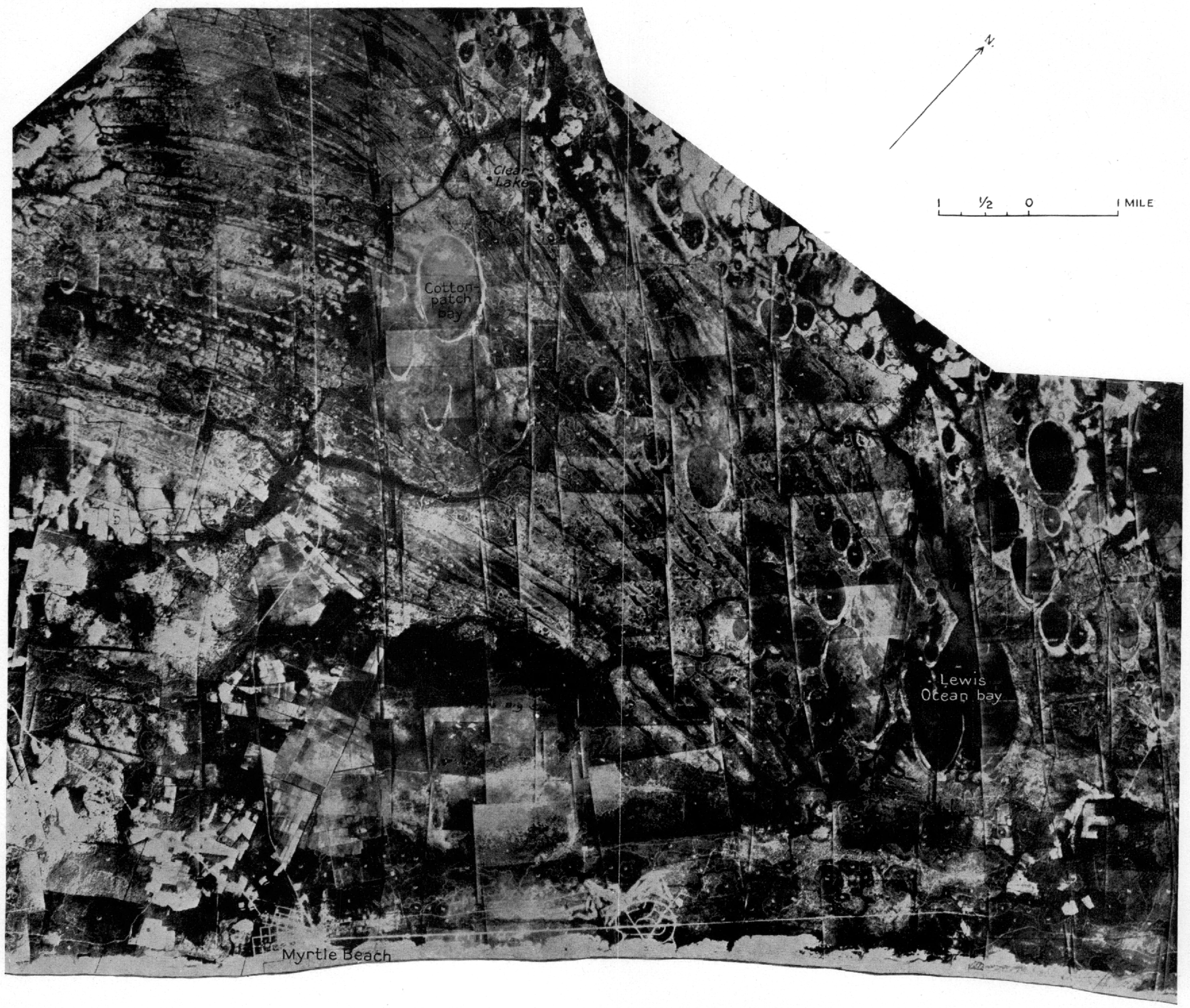

$A T L A N T / C$

$O C E A N$

MOSAIC OF AERIAL PHOTOGRAPHS OF PART OF HORRY COUNTY BETWEEN WACCAMAW RIVER AND THE OCEAN. 



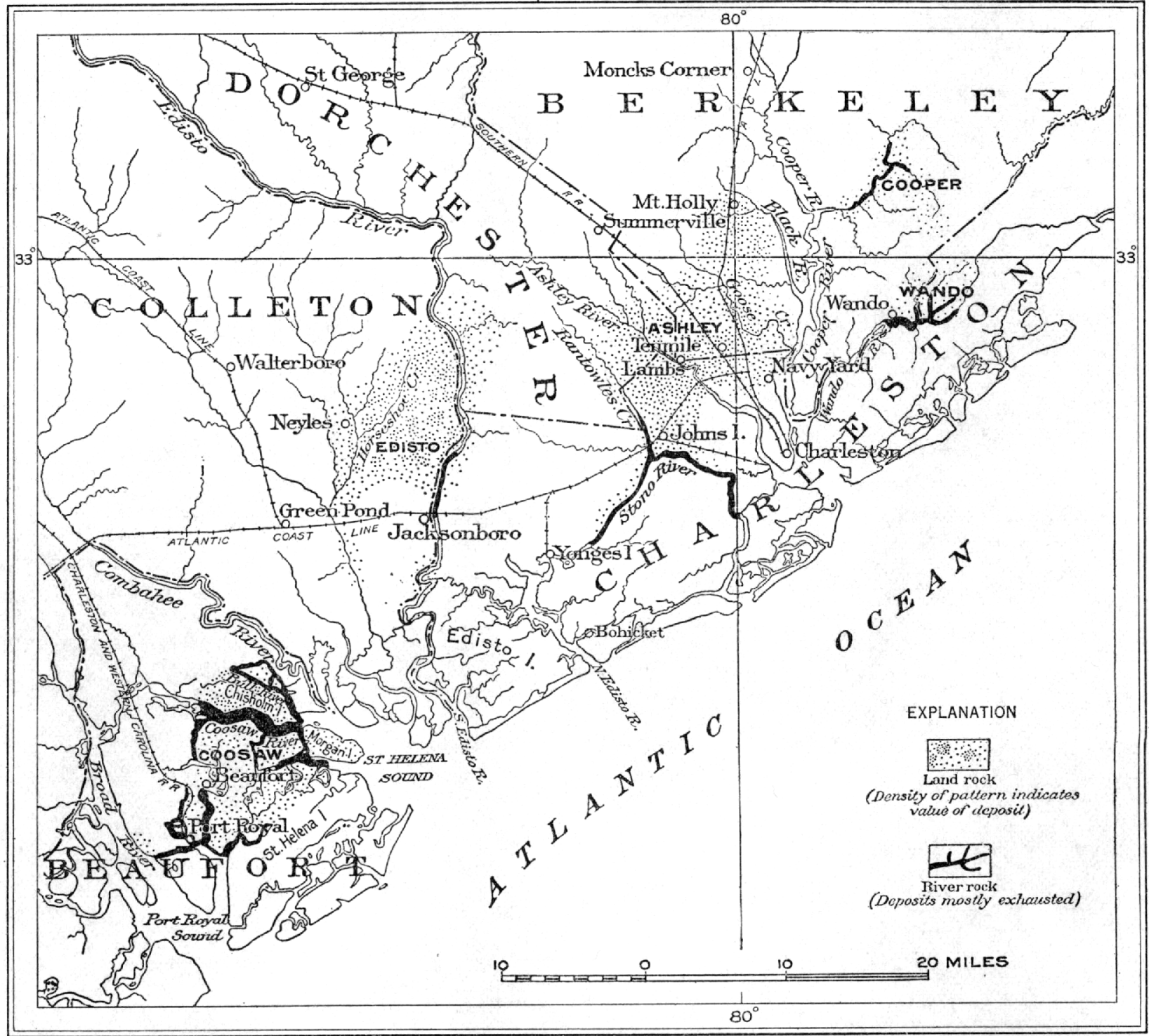

MAP SHOWING THE APPROXIMATE ORIGINAL DISTRIBUTION OF PHOSPHATE DEPOSITS IN SOUTH CAROLINA. After Rogers, G. S., U. S. Geol. Survey Bull. 580, pl. 2. 

rock. The decomposed feldspar, grains of quartz, and flakes of mica from the rotten granitic rocks yielded readily to erosion and were carried down to tidewater. The streams of that day may have been milky with suspended kaolin. This is the source of the sand beds and kaolin lenses of the Tuscaloosa formation.

After a time this kind of deposition ceased. The surface of the Tuscaloosa probably was near sea level-possibly a few feet above, perhaps covered by shallow water. Then came a transgression of the sea in which were deposited first a layer of pebbles, next fine darkcolored sand and laminated clay-the Black Creek formation-and finally alternating beds of light-colored sand, dark sand, and black clay with shells - the Snow Hill marl member.

So far as known there is no stratigraphic break between the Black Creek formation and the overlying Peedee formation in North Carolina, ${ }^{57}$ but in South Carolina the basal part of the Peedee is absent, indicating a temporary emergence at the end of Black Creek time. This emergence was followed by submergence that brought in the Exogyra costata fauna.

At the end of the Upper Cretaceous epoch crustal movements once more brought the continental margin above the sea, where it remained for a very long time. The interval of emergence was longer in South Carolina and in the States north of it than in the region farther south, for no deposits of Midway (lower Eocene) age have been found north of Georgia.

In Wilcox time the sea again invaded South Carolina, reaching as far inland as Richland County, but if it covered the southern part of the State most of its deposits have since been eroded away. The sediments of this time (Black Mingo formation) were chiefly sand and clay resembling fuller's earth. The same sea covered much of the Coastal Plain of North Carolina and extended northeastward to New Jersey, for there are patches of fossiliferous sandstone near Lillington, N. C., and glauconitic deposits (Aquia formation and Rancocas group) farther north that seem to be of the same age as the Black Mingo formation.

The sea withdrew toward the end of Wilcox time but advanced again during the Lisbon part of Claiborne time and deposited the fine sand and sandy marl of the McBean formation. The continental warping that admitted the sea as far north as Lexington County may have kept it out of the region east of the Santee River, for no deposits of Claiborne age have been discovered between the Santee River and Virginia. No deposits of late Claiborne (Yegua) time are known in South Carolina.

n Stephenson, L. W., The Cretaceous formations of North Carolina, pt. 1: North Carolins Geol. Burvey. vol. 5, pt. 1, p. 8, 1923. 
Jackson (late Eocene) time began with a crustal movement that raised the region between the Cape Fear River in North Carolina and the Santee River in South Carolina, thus producing the "Great Carolina Ridge" (see p. 158), and depressed the regions on both sides of it. The sea transgressed beyond its former limits and reached the Piedmont. Its deposits at the beginning of this time were prevailingly limy (Tivola tongue of the Ocala limestone in Georgia, Santee limestone in South Carolina, and Castle Hayne marl in North Carolina) but later became sandy near shore (Barnwell formation), although limy ooze (Ocala limestone in Georgia, Cooper marl in South Carolina). was deposited farther out to sea. At the end of the Eocene the continent again emerged.

The next invasion of marine waters in South Carolina came in late Oligocene time, when the Flint River formation was deposited in Allendale County.

South Carolina remained land during the early part of lower Miocene time, but in the later part of that time the sea covered the southern part of the State, two-thirds of the Coastal Plain of Georgia, and almost all of Florida. The Carolina Ridge and probably most of the region north of it remained land. The Hawthorn formation was laid down then. The deposits of the Hawthorn sea were prevailingly phosphatic sand and clay. No deposits of middle Miocene time or of the early part of upper Miocene time are known in South Carolina, but a small remnant of beds (Raysor marl) equivalent to a lower part of the Yorktown formation shows that the sea probably covered a wide coastal strip in the middle part of late Miocene time. Larger patches of the Duplin marl show that the Carolina Ridge had been eroded and submerged beneath the sea in late upper Miocene time. This submergence extended from Virginia to Florida.

During the Pliocene epoch the seashore lay perhaps 40 miles inland from its present position in South Carolina. It extended across North Carolina, intersected the present seashore somewhere in the neighborhood of Chesapeake Bay, and continued northeastward to the edge of the Continental Shelf. The northern region stood high, and most of the Coastal Plain and Continental Shelf there were dry land. While sand and shell marl were accumulating to make up the Waccamaw formation in the Carolinas the northern land was being actively eroded; Chesapeake Bay and Delaware Bay apparently were river valleys, and the Hudson River was probably cutting a gorge across the emerged Continental Shelf. The widespread movements of the crust of the earth that ended the Pliocene epoch depressed the northern land and submerged the Coastal Plain there. South Carolina, too, was involved in this downwarp but to a less extent; it went down 
only about 170 feet, whereas the former mouth of the Hudson River may have been drowned to a depth of several thousand feet.

The beginning of the Pleistocene or glacial epoch probably found the sea level about 270 feet higher than today. Since that time there have been no recognizable movements of the land in this region, but sea level appears to have fluctuated down and up repeatedly, the net result being a lowering of sea level. One cause of this lowering may have been an increase in the capacity of the ocean basins by crustal movements elsewhere. Another and probably the dominant cause of the fluctuations of sea level may have been glacial control. The amount of water in the sea and, consequently, its relative level vary inversely with the amount of ice upon the land; at times of extensive glaciation sea level is probably lower; when the ice melts and its water flows into the sea, sea level is probably higher. The present stage of sea level is intermediate between these highs and lows, for there is now partial glaciation in high latitudes and at high altitudes.

Seven stages of sea level higher than the present, during which were formed the seven coastal terraces (see p. 6), have been recognized, and there may be others that have escaped detection. Theoretically, there should have been five times of low sea level corresponding to the five glacial stages. There is evidence that the sea was low before it stood at the 100-foot (Wicomico) level and again before the 25-foot (Pamlico) level; but which of the glacial stages are represented by these two lows and where the three other lows come in the sequence has not been definitely established.

During each low stage of sea level gorges were cut in the exposed sea bottoms by the streams that flowed across them. The succeeding rise of sea level backed tidewater up the lower courses of all the streams and converted them into estuaries. Some of the present estuaries may have been cut during one of the early Pleistocene lowwater stages and may have been flooded during each of the subsequent high-water stages and reoccupied by streams whenever tidewater withdrew from them; others may be younger valleys, carved during the latest retreat of the sea. All the harbors of the State are in these. drowned valleys.

Although the continental ice sheets appear to have had a profound influence on the Pleistocene history of South Carolina by causing fluctuations of sea level, the ice sheets themselves stopped far to the north. The climate in South Carolina during the glacial stages may. not have been much colder than at present, and the interglacial stages, during which the formations now accessible were deposited, were probably somewhat warmer than the average temperature of today. 


\section{STRUCTURE}

The present structure or attitude of the rocks in the Coastal Plain of South Carolina is the resultant of all the movements to which the region has been subjected during the geologic past.

In early Cretaceous time there was a broad, fairly even plain, sloping gently southeastward, composed of schists, granites, and other crystalline rocks like the rocks of the Piedmont province, with patches of Triassic shale, sandstone, and diabase. Upon this bedrock were laid down one upon another the Tuscaloosa, Black Creek, and Peedee formations of Upper Cretaceous age. If the cover of younger deposits were removed the Upper Cretaceous formations would appear in three nearly parallel bands trending southwestward across the State. The surface of these Cretaceous beds as well as the surface of the bedrock on which they lie is warped; along the northwest border (the edge of the Piedmont) it is nearly level, but in the eastern part of the State it is tilted toward the south.

Upon the eroded surface of all three Upper Cretaceous formations in the area north of the Santee River lie large patches of the thin Black Mingo formation, of Wilcox Eocene age, which probably participates in the gentle southward tilt of the underlying beds superimposed upon its normal seaward slope. In the area southwest of the Congaree River the Tuscaloosa and probably the other two Cretaceous formations are overlain by the McBean formation, of Claiborne Eocene age, which also probably slopes gently southward at about the same rate as the warped surface of the Upper Cretaceous formations upon which it rests.

Upon the McBean and Black Mingo formations lie the three formations of upper Eocene (Jackson) age - the Santee limestone, Barnwell sand, and Cooper marl. These formations seem to dip gently southward but increase in thickness down the dip to such an extent that the surface of the Cooper is an almost level plain. This plain may sag a little in the middle along the Savannah River, where the late Oligocene Flint River formation rests upon it in Allendale County.

The Upper Cretaceous and Eocene formations are the only deposits in the Coastal Plain of South Carolina that are conspicuously deformed. They make up the southwest limb of the "Great Carolina Ridge", whose crest or axis lies not far from the North CarolinaSouth Carolina State line and nearly parallel to it and whose northeast limb is in North Carolina. This ridge is the dominant structural feature of the Coastal Plain of the Carolinas. It was formed during late Eocene time by a buckling of the earth's crust that arched up the rocks along the axis of the ridge and bent down the rocks on each side of it, thus admitting the Jackson sea to a former land surface and causing it to transgress beyond the limits of older Eocene and Upper Cretaceous formations and to flood the borders of the Piedmont. 
Upon the beveled surface of the Great Carolina Ridge lie thin patches of nearly horizontal marine Miocene formations (remnants separated by erosion) and more extensive sheets of marine Pleistocene terrace deposits.

\section{MINERAL RESOURCES}

METALS

No veins of gold, silver, platinum, copper, or other metallic ores are to be looked for in the Coastal Plain of South Carolina, because all the rocks of the Coastal Plain are of sedimentary origin and have undergone little alteration since their deposition, whereas metallic ores commonly occur in igneous or metamorphic rocks or in sedimentary rocks that have been partly metamorphosed. Iron-bearing minerals are widely disseminated throughout the region but are nowhere present in sufficient abundance to be of economic value now. They are probably not even of potential value.

\section{NONMETALS}

\section{PHOSPHATE ROCK}

At one time South Carolina was one of the largest producers of phosphate rock in the world. Production began in 1867 with 6 tons, reached a maximum of 541,645 tons in 1889 , and ceased in 1925 . The known accessible deposits are now nearly exhausted. The phosphatic deposits lie within a coastal strip about 30 miles wide that extends from the Broad River in Beaufort County to the headwaters of the East Branch of the Cooper River in Berkeley County. (See pl. 18.)

The phosphate rock is of two kinds- "land rock" and "river rock." The land rock is phosphatic marl or limestone of the Miocene Hawthorn formation ( $\dagger$ Edisto marl) that has been enriched by deposition within its pores of additional phosphate brought in by circulating water from the surrounding rock or from rock that has been weathered away from above it. The river rock consists of pebbles of land rock that have accumulated in watercourses.

The phosphate deposits of South Carolina were described in 1914 by Rogers, ${ }^{58}$ whose paper cites references to earlier literature.

\section{LTMESTONE AND CALCAREOUS MARL}

The principal deposits of limestone and calcareous marl in the Coastal Plain of South Carolina are in the Santee limestone and the Cooper marl, both of which are available in large quantity. All the Miocene formations-Hawthorn, Raysor, and Duplin-contain some impure limestone or shell marl, and the same is true of the Pliocene Waccamaw formation and the Pleistocene Pamlico formation. The Upper Cretaceous Peedee formation also contains ledges

\footnotetext{
s8 Rogers, S. C., The phosphate deposits of South Caroline: C. S. Geol. Survey Bull. 580, pp. 183-200, 1914.
} 
of marlstone that may be of some local use. Some parts of the Eocene McBean formation contain marl.

All the marl beds of South Carolina are nearly horizontal. Most of them lie within the area of the constal terraces and are covered by terrace deposits. For that reason most of the natural outcrops are near watercourses, where the surface of the ground is lower than the terrace level. As few of the streams have sunk their valleys very deep into the plain, only shallow pits can be drained without pumping.

Most of the limestone and marl is too soft for use as building stone, but much of it is suitable for making lime or for use, when ground, as a soil conditioner. For these purposes it might supply the local market.

The limestone and marl deposits of South Carolina have been briefly described by Calhoun, ${ }^{59}$ and many analyses of the rock are given by Sloan. ${ }^{60}$

\section{CLAX}

The clay deposits are a valuable resource of the Coastal Plain. They may be classified in three divisions-sedimentary kaolin, bleaching clay, and brick and tile clay.

The kaolin deposits of commercial value are found only in the Tuscaloosa formation, which lies at the surface in Aiken, Lexington, Calhoun, Richland, Kershaw, Sumter, Lee, Chesterfield, Darlington, and Marlboro Counties. They have been exploited chiefly in Aiken and Lexington Counties. The deposits consist of high-grade white or light-colored clays that occur as lenses of irregular thickness between beds of sand. Production in 1932 amounted to 71,994 short tons, valued at $\$ 461,025$.

A search for bleaching clay in the Coastal Plain of South Carolina was made in 1934 by Harry X. Bay for the United States Geological Survey, but no deposits of present commercial value were discovered. Tests of samples of so-called "fuller's earth" from the Black Mingo formation in Sumter, Clarendon, and Williamsburg Counties show that the bleaching properties of the clay and shale there are slight. The McBean formation in Calhoun County contains a little low-grade fuller's earth. The Barnwell sand in Aiken County contains some small deposits of fuller's earth comparable in quality with that of the same age in central Georgia.

Brick and tile clay is widely distributed through the Coastal Plain, particularly in the terrace deposits bordering the larger rivers (as near Kollock) or in former lagoons back of ancient barrier islands (as at Drainland, 2 miles northwest of Summerville).

s9 Calhoun, F. H. H., Limestone and marl deposits of South Carolina: South Carolina Agr. Exper. Sta. Bull. 183, 27 pp., 1915.

co Sloan, Earle, Catalogue of the mineral localities of South Carolina: South Carolina Geol. Survey, ser. 4, Bull. 2, pp. 265-326, 1908. 
The high-grade clays (kaolins) of South Carolina have been described by Bayley, ${ }^{61}$ and all classes of clays have been described by Sloan. ${ }^{62}$

\section{SAND AND GRAVEL}

There is some sand in nearly all parts of the Coastal Plain of South Carolina. Those formations in which it is most likely to be of commercial importance are the Upper Cretaceous Tuscaloosa formation, the Eocene McBean formation, and the Pleistocene terrace deposits. There are large sand pits at Sand Mountain, in eastern Lexington County north of Gaston.

Gravel is less widely distributed than sand. It is most abundant in the neighborhood of the large rivers, particularly in the region just below the Fall Line. There are extensive deposits in Marlboro County and near Columbia.

\section{MINERAL FUELS}

There are no deposits of anthracite or bituminous coal in the Coastal Plain. A few thin seams of lignite and carbonaceous clay have been noted in the Upper Cretaceous Black Creek formation and in the Eocene Black Mingo formation, but none of them appear to be of even potential economic value.

No indications of the presence of petroleum or natural gas have been discovered in South Carolina, although several wells have been drilled completely through the Tertiary and Cretaceous sediments into the crystalline rocks that underlie them. A test well was carefully drilled in 1920 or 1921 at Summerville (see p. 177) to a depth of at least 2,570 feet, at which it was in igneous rock. Conditions in the entire State appear to be very unfavorable for the existence of petroleum or natural gas in commercial quantities.

\section{GROUND WATER}

The most valuable mineral resource of South Carolina is water. Water supplies are of two kinds-underground and surface. Only the underground supplies will be discussed here.

The following account of the ground waters of the Coastal Plain of South Carolina is not intended to be complete or exhaustive. It is based chiefly upon well records and water samples collected in 1917; but some supplementary data were obtained in later years. As most of the information about wells was given from memory by well drillers or other persons and is not based upon data recorded when the wells were drilled, some of it may be defective.

a1 Ries, Heinrich, Bayley, W. S., and others, High-grade clays of the eastern United States: U. S. Geol. Survey Bull. 708, pp. 164-194, 1922.

62 Slosn, Earle, A preliminary report on the clays of South Carolina: South Carolina Geol. Survey, ser. 4, Bull. 1, 1904. 


\section{SOURCES OF GROUND WATER}

Tuscaloosa formation.-The Tuscaloosa is one of the most productive water-bearing formations in the Coastal Plain of South Carolina. It contains a great deal of sand through which water can circulate freely. The considerable width of its outcrop (see pl. 2) permits much rain to fall directly upon it, and even where it is buried its store of water is added to by seepage through the porous formations (Black Mingo, McBean, Barnwell, and Brandywine) that overlie it.

The Tuscaloosa formation lies at or near the surface in Marlboro, Chesterfield, Darlington, Kersbaw, Lee, western Sumter, Richland, northern Calhoun, Lexington, and Aiken Counties, and most of the wells in that region draw their water from it. Farther south it is more deeply buried, but it has been reached by many wells. It appears to be the formation that yields the plentiful supplies of water that come from a depth of about 1,000 feet in Hampton County.

Water derived from the Tuscaloosa formation is soft. Along the outcrop and where the formation is not deeply buried the water is. very pure. Even as far away from the outcrop as Hampton County the water is only moderately mineralized, but a slight increase in mineralization down the dip can be detected even within the limits of that county.

Black Creek formation.-The Black Creek formation consists chiefly of dark-gray laminated clay and sand. Outcrops are not very numerous because the formation is overlapped by Eocene, Miocene, and Pleistocene deposits. It lies nearest the surface in Dillon, Marion, Darlington, and Florence Counties and perhaps in western Sumter and Clarendon Counties. It is more deeply buried in the region south of the Santee River. As the intake area of the Black Creek formation lies considerably lower than the intake area of the Tuscaloosa formation, water in the Black Creek is under less pressure than that in the Tuscaloosa.

Water drawn from the Black Creek formation is soft. It is, however, more highly mineralized than that from the Tuscaloosa and contains more sodium bicarbonate. Many flowing wells in Horry and Georgetown Counties appear to draw their water from the Black Creek formation. A 2,000-foot well at Charleston is thought to obtain its water from this source. ${ }^{63}$

Peedee formation.-The Peedee formation consists of gray sandy marl interbedded with thin ledges of marlstone. It is overlapped by Eocene, Miocene, and Pleistocene deposits but is near the surface in Horry, southern Marion, southern Florence, Williamsburg, and Georgetown Counties. It lies deeper in the southern part of the State. At Charleston it is apparently between 440 and 1,550 feet

\footnotetext{
stephenson, L. W., A deep well at Charleston, S. C.: U. S. Geol. Survey Prof. Paper 90, pp. 69-90.
} 1914 . 
below the surface. At Summerville its top seems to be about 313 feet below the surface.

As the Peedee formation contains considerable lime, the water in it might be expected to be hard; however, most of the water from this formation contains more sodium than calcium or magnesium and is soft.

Black Mingo formation.-The Black Mingo formation occurs chiefly in Lee, Sumter, Clarendon, Williamsburg, and Georgetown Counties. It has not been recognized in deep wells outside of this area and probably does not extend far southwestward beneath the McBean formation and the Santee limestone. The Black Mingo consists of sand and clay. Little is known about the quantity or the quality of the water in it, but the less argillaceous parts of it probably contain enough water for the domestic use of farms and small communities, and the water probably contains no objectionable mineral ingredients except possibly iron.

McBean formation.-The McBean formation underlies an area in Calhoun, Lexington, Orangeburg, Barnwell, and Aiken Counties. In much of Barnwell and Aiken Counties it is overlain by the Barnwell sand, but it probably does not extend southward or eastward under cover far beyond the limits shown on plate 2. The McBean consists chiefly of fine sand, laminated clay, glauconitic marl, and impure limestone. It seems to contain a plentiful supply of water that is slightly hard.

Santee limestone and Cooper marl.-The Santee limestone and the Cooper marl together underlie most of the "low country" between the Savannah and Santee Rivers, where they are covered, for the most part, with deposits of Oligocene, Miocene, Pliocene, or Pleistocene age. The Santee limestone contains some sand and glauconite, but the Cooper marl contains fewer impurities. In the vicinity of Charleston the two formations aggregate about 440 feet in thickness.

The water in the Santee limestone and the Cooper marl is presumably hard, but there are few data at hand regarding the quantity or quality of this water, as the drillers of most of the wells of which there is record found it desirable to tap formations below the Santee.

Barnwell sand.-The principal area underlain by the Barnwell sand is in Barnwell, Aiken, and Lexington Counties. This formation consists of sand with local beds of marl or limestone at the bottom, probably aggregating less than 200 feet in thickness. The water in it is probably excellent.

Flint River formation.-The Flint River formation occupies a small area in Allendale County. It consists chiefly of sand and silicified limestone. No data concerning the water in it are available.

Hawthorn formation.-The Hawthorn formation underlies a broad strip extending eastward from Hampton County through the southern 
part of Berkeley County. It is almost everywhere covered by fine Pleistocene sand and loam. It consists of fine, generally phosphatic sand, fuller's earth, marl, and impure limestone. The maximum recorded thickness is 160 feet. Water in the Hawthorn is probably hard, because the formation contains so much lime.

Raysor marl, Duplin marl, and Waccamaw formation.-The Raysor marl, because of its small extent, is negligible as an aquifer. The Duplin marl and the Waccamaw formation are more extensive but thin; it is likely that a small amount of hard water can be obtained from them.

Pleistocene formations.-The Brandywine, Coharie, Sunderland, Wicomico, Penholoway, and Talbot formations consist chiefly of sand and gravel. They hold considerable water, which is tapped by many dug or drilled wells. Most of the water is of excellent chemical quality, but it is more liable to pollution than that from deeper beds. The Pamlico formation includes fine sand, clay, and shells. This formation is less likely to yield water than the more porous beds, and the water is more likely to be sulphurous. The distribution of the Pleistocene formations is shown on plate 1.

\section{DESCRIPTION BY COUNTIES}

AIREN COUNTY

Most of the wells in Aiken County probably tap the Tuscaloosa formation, which carries considerable water of good quality. Those on the upland range in depth from about 100 to 200 feet. Water in these upland wells does not rise far above the point of intake, but there may be deeper beds in the Tuscaloosa formation that carry water under greater pressure. However, it is not likely that flowing wells can be obtained anywhere in Aiken County except in the valley of the Savannah River and possibly along the Edisto. Records of some of the wells are given below.

Wells in Aiken County

\begin{tabular}{|c|c|c|c|c|c|}
\hline No. & Place & Owner & $\begin{array}{c}\text { Depth } \\
\text { (feet) }\end{array}$ & $\begin{array}{l}\text { Diameter } \\
\text { (inches) }\end{array}$ & $\begin{array}{l}\text { Level of } \\
\text { water below } \\
\text { surface } \\
\text { (feet) }\end{array}$ \\
\hline 1 & $\begin{array}{l}\text { Aiken, } 2 \text { miles south of, on Hawthorne } \\
\text { Road. }\end{array}$ & Fabian Summerall.. & 195 & 2 & 150 to 160 \\
\hline 2 & New Harlem. & S. B. Williams ...... & 135 & 21,2 & 110 \\
\hline 3 & Berlin_.... & Public school & 140 & 2 & 110 \\
\hline 4 & Wagener, 3 blocks northeast of station... & D. K. Gantt ......... & $\begin{array}{l}135 \\
132\end{array}$ & $\begin{array}{l}2 \\
2\end{array}$ & $\begin{array}{l}100 \\
112\end{array}$ \\
\hline 6 & $\begin{array}{l}\text { Wagener, } 2 \text { blocks northeast of station.- } \\
\text { Ellenton. }\end{array}$ & $\begin{array}{l}\text { George Johnson..... } \\
\text { Town }\end{array}$ & 350 & 436 & Flows \\
\hline$?$ & White Pond, 2 miles southwest of & Chester Smith...... & 95 & 2 & 70 \\
\hline 8 & Salley & Town & & & \\
\hline
\end{tabular}

The flowing well at Ellenton (no. 6), gets most of its water from a depth of 210 feet. The analysis shows that the water contains little mineral matter in solution. The slight hardness suggests that at 
least some of the water comes from the McBean formation, for water from the Tuscaloosa formation is generally soft.

\section{Analysis of ground water from Ellenton, Aiken County}

[Analyst, Alfred A. Chambers. No. 6 in preceding table]

Iron (Fe) $\ldots \ldots \ldots \ldots$

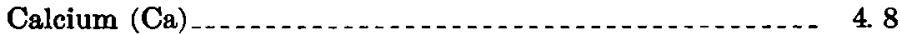

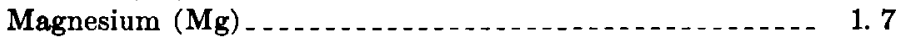

Sodium and potassium $(\mathrm{Na}+\mathrm{K})$ (calculated) $\ldots \ldots \ldots .1$

Bicarbonate $\left(\mathrm{HCO}_{3}\right)_{\ldots} \ldots \ldots$

Sulphate $\left(\mathrm{SO}_{4}\right)$

Chloride (Cl) $\ldots \ldots \ldots$

Nitrate $\left(\mathrm{NO}_{3}\right) \ldots \ldots$

Total dissolved solids _........... 63

Total hardness as $\mathrm{CaCO}_{3}$ (calculated) _................ 19

Date of collection . . . . . . . . . . . . . . . . . . . 6 , 1917

\section{ALLENDALE COONTY}

Strong flows can be obtained from deep wells anywhere in the southeastern half of Allendale County and in the lowlands near the Savannah River and its tributaries. In the remainder of the county, water will probably rise high in the wells but may not overflow. The depth to the principal water-bearing stratum in the Tuscaloosa formation increases toward the south from 575 feet at Ulmers to 880 feet at the Winthrop Club. Another water-bearing stratum, probably at the base of the Santee limestone, lies 400 feet or less below the surface but is little used because water from it does not generally overflow.

Wells in Allendale County

\begin{tabular}{|c|c|c|c|c|c|}
\hline No. & Placo & Owner & $\underset{\text { (feet) }}{\text { Depth }}$ & $\begin{array}{c}\text { Dismeter } \\
\text { (inches) }\end{array}$ & $\begin{array}{c}\text { Level of } \\
\text { water above } \\
\text { on below } \\
\text { surface } \\
\text { (feet) }\end{array}$ \\
\hline \begin{tabular}{r|}
1 \\
2 \\
3 \\
4 \\
5 \\
6 \\
7 \\
7 \\
8 \\
9 \\
10
\end{tabular} & $\begin{array}{l}\text { Allendale (old well) } \\
\text { Alendale. } \\
\text { Fairfax } \\
\text { Üimers.do } \\
\text { Appleton } \\
\text { Martin, } 1 \text { mile north of } \\
\text { Baldock } \\
\text { Jenny's } \\
\text { Luray, } 7 \text { miles west of }\end{array}$ & 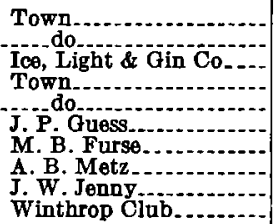 & $\begin{array}{c}800 \\
752 \\
674 \\
640 \\
575 \pm \\
220 \\
72 \\
97 \\
800 \\
880\end{array}$ & $\begin{array}{l}3 \\
8 \\
6 \\
21 / 2 \\
2 \\
2 \\
2 \\
2 \\
2 \\
45 / 52\end{array}$ & $\begin{array}{r}+6 \\
\text { Flows } \\
\text { Flows } \\
\text { Flows } \\
+40 \\
+120 \\
+40 \\
\text { Flows } \\
+40 \\
\text { Flows }\end{array}$ \\
\hline
\end{tabular}

Analyses of samples from three wells in Allendale County show that the water is fairly low in mineral content. 


\section{Analyses of ground waters from Allendale County}

Analysts: 2, A. A. Chambers; 3, Margaret D. Foster; 8, A. A. Chambers and C. H. Kidwell. Parts per million. Numbers at heads of columns refer to corresponding well numbers in preceding table]

\begin{tabular}{|c|c|c|c|}
\hline & 2 & 3 & 8 \\
\hline 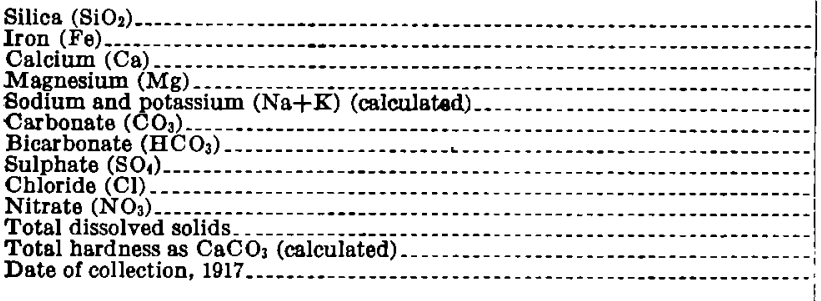 & $\begin{array}{c}0.20 \\
22 \\
4.4 \\
13 \\
15 \\
70 \\
12 \\
4.1 \\
0 \\
200 \\
73 \\
\text { Nov. } 14\end{array}$ & $\begin{array}{l}36 \\
\quad .92 \\
2.4 \\
32.3 \\
12 \\
63 \\
13 \\
4.9 \\
\text { Trace } \\
132 \\
23 \\
\text { Nov. } 14\end{array}$ & $\begin{array}{l}21 \\
42 \\
3.6 \\
4.6 \\
0 \\
136 \\
12 \\
4.0 \\
\text { Trace } \\
155 \\
120 \\
\text { JuIy } 2\end{array}$ \\
\hline
\end{tabular}

\section{BAMBERG COUNTY}

Flowing wells can be had anywhere within the southeastern twothirds of Bamberg County. Information about the northwestern part is scanty, but it is doubtful whether wells there will flow, because the land is too high. A 150 -foot well at Denmark does not flow. At Bamberg, strong flows are obtained, probably from the Tuscaloosa formation, at depths between 450 and 550 feet. The town well is about 500 feet deep. Other wells at Bamberg are from 50 to 85 feet deep. A flowing well at Schofield's mill, between Olar and Ulmers, is 745 feet deep. This, also, probably taps the Tuscaloosa formation. The 6-inch town well at Ehrhart is 575 feet deep. It will flow 12 feet above the ground.

\section{BARN WELL COUNTY}

Most of Barnwell County is too high for wells to overflow, but anywhere in the valley of the Savannah River flowing wells can probably be obtained from the Tuscaloosa formation at depths greater than 200 feet. A 103-foot well at the site of J. M. Farrell's old mill on Turkey Creek, 5 miles west-southwest of Blackville, flows about 10 gallons a minute. The depths of some representative wells in Barnwell County are shown below.

Wells in Barnwell County

\begin{tabular}{|c|c|c|c|c|c|}
\hline No. & Place & Owner & $\begin{array}{c}\text { Depth } \\
\text { (feet) }\end{array}$ & $\begin{array}{c}\text { Diamoter } \\
\text { (inches) }\end{array}$ & $\begin{array}{c}\text { Level of } \\
\text { water below } \\
\text { surface } \\
\text { (feet) }\end{array}$ \\
\hline 1 & Barnwell. & Town... & 155 & 41/2. & 27 \\
\hline .2 & Barnweli is mile north of & R. Ellis & 157 & 6 & $\begin{array}{l}27 \\
50+\end{array}$ \\
\hline .3 & $\begin{array}{l}\text { Barnwell, } \text {;/2 mile north of } \\
\text { Barnwell, poor farm }\end{array}$ & 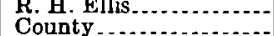 & $\begin{array}{r}110 \\
90\end{array}$ & $\begin{array}{l}2 \\
2\end{array}$ & $\begin{array}{l}50 \pm \\
60 \pm\end{array}$ \\
\hline .5 & Kline, 2 miles east of & T. F. Hogg & 409 & 4 & 43 \\
\hline .6 & Hattieville, 1 mile northeast of ... & G. D. Kirklin & 130 & 2 & 60 \\
\hline .7 & Barnwall, 12 miles west of ....... & Joyce Branch Chureh... & 135 & 2 & 13 \\
\hline 8 & Dunbarton & Town & 100 & 3 & 60 \\
\hline 9 & Williston_.. & .... do & 198 & 10 & 18 \\
\hline 10 & ..... do... & . do & 206 & 10 & 26 \\
\hline 11 & do do & Arthur Canada & 136 & 2 & 40 \\
\hline 12 & Blackville, Main Street and Railroad & J. M. Farrell..... & 380 & 6 & 60 \\
\hline 13 & $\begin{array}{l}\text { Turkey Creek, } 5.3 \text { miles west of } \\
\text { Black ville, at old mill. }\end{array}$ & ..... do.... & 103 & 6 & Flows \\
\hline
\end{tabular}


Analyses of water from two of these wells show that the water is somewhat hard but otherwise low in mineral content. The hardness. of the water suggests that it comes from the McBean formation rather than from the Tuscaloosa.

\section{Analyses of ground waters from Barnwell County}

[Analysts, A. A. Cbambers and C. H. Kidwell. Parts per million. Numbers at heads of columas refer to corresponding well numbers in preceding table]

\begin{tabular}{|c|c|c|c|c|c|}
\hline & 12 & 13 & & 12 & 13 \\
\hline $\begin{array}{l}\text { Silica }\left(\mathrm{SiO}_{2}\right) \\
\text { Iron }(\mathrm{Fe}) \\
\text { Calcium }(\mathrm{Ca}) \\
\text { Magnesium }(\mathrm{M} 2) \\
\text { Sodium and potassium }(\mathrm{Na}+\mathrm{K}) \\
\text { (calculated) } \\
\text { Carbonate }\left(\mathrm{C} \mathrm{O}_{3}\right) \\
\text { Bicarbonate }\left(\mathrm{HCO}_{3}\right)\end{array}$ & $\begin{array}{l}39 \\
45^{.24} \\
1.5 \\
11 \\
\text { Trace } \\
135\end{array}$ & $\begin{array}{r}14 \\
40 \\
1.5 \\
7.5 \\
2.5 \\
125\end{array}$ & $\begin{array}{l}\text { Sulphate (SOH) } \\
\text { Chloride (Cl) } \\
\text { Nitrate (NO } \mathrm{NO}_{3} \text { ) } \\
\text { Total dissolved solids } \\
\text { Total hardness as } \mathrm{Ca} \mathrm{CO}_{3} \text { (cal- } \\
\text { culated) } \\
\text { Date of collection, } 1917\end{array}$ & $\begin{array}{c}24 \\
4.7 \\
\text { Trace } \\
197 \\
119 \\
\text { June } 29\end{array}$ & $\begin{array}{r}9.7 \\
3.4 \\
\text { Trace } \\
141 \\
106 \\
\text { June } 29\end{array}$ \\
\hline
\end{tabular}

BEAUFORT COUNTY

Water can be obtained almost anywhere in Beaufort County from wells 200 feet deep or less. On very low land the wells overflow; some of them fluctuate with the tides and may cease flowing at low tide. In most wells on higher land the water stands a few feet below the top. As shown by the unalyses, the water is not very highly mineralized and is good for most uses.

A 710-foot well drilled in 1907 for the Charleston Mining \& Manufacturing Co. on Chisholms Island, 7 miles northeast of Beaufort (no. 8 in table), entered the Cooper marl at a depth of 57 feet and reached a water-bearing sand at a depth of 681 feet. The natural flow from this well yielded about 10 gallons a minute, and the yield could te greatly increased by pumping. The water-bearing stratum seems to lie just beneath or within the Santee limestone. It probably increases in depth toward the southwest.

It is possible that wells drilled to a depth of 1,200 feet or more in the southwestern part of the county might get strong flows from the Tuscaloosa formation, which supplies Hampton County, but if water is obtained from the Tuscaloosa it is likely to be more highly mineralized here than in Hampton County.

Wells in Beaufort County

\begin{tabular}{|c|c|c|c|c|c|}
\hline No. & Place & Owner & $\begin{array}{l}\text { Depth } \\
\text { (feet) }\end{array}$ & $\begin{array}{l}\text { Diameter } \\
\text { (inches) }\end{array}$ & $\begin{array}{l}\text { Level of } \\
\text { water be- } \\
\text { low surface } \\
\text { (feet) }\end{array}$ \\
\hline 1 & Beaufort & \multirow{2}{*}{ Town } & \multirow{2}{*}{$\begin{array}{r}125 \\
90\end{array}$} & \multirow{2}{*}{$\begin{array}{l}10 \\
21 / 2\end{array}$} & \multirow{2}{*}{$\begin{array}{r}211 / 2 \\
\text { Flows }\end{array}$} \\
\hline 2 & $\begin{array}{l}\text { Bluffton, bank of May River be- } \\
\text { low level of high tide. }\end{array}$ & & & & \\
\hline 3 & Okatie. & \multirow{4}{*}{$\begin{array}{l}\text { P. M. Cooler } \\
\text { Town. } \\
\text { P. A. Cooler } \\
\text { J. W. Guerard. } \\
\text { U. S. Navy }\end{array}$} & \multirow{4}{*}{$\begin{array}{r}165 \\
85 \\
196 \\
125 \\
100\end{array}$} & \multirow[t]{2}{*}{2} & \multirow{2}{*}{$\begin{array}{l}0 \\
0\end{array}$} \\
\hline $\begin{array}{l}4 \\
5\end{array}$ & $\begin{array}{l}\text { Yemassee, } \\
\text { old House, } 2.2 \text { miles couth of }\end{array}$ & & & & \\
\hline 6 & Bull Isiand & & & 2 & $0^{2}$ \\
\hline 7 & $\begin{array}{l}\text { U. S. Marine Barrarks. Parris } \\
\text { Island. }\end{array}$ & & & 8 & 18 \\
\hline 8 & Chisholms Island & Charleston Mining \& Man- & 710 & 6 & Flows \\
\hline 9 & Frogmore, St. Helena Island. & $\begin{array}{l}\text { Penn Normal. Industrial, } \\
\text { and Agricultural School. }\end{array}$ & 960 & 6 & -............... \\
\hline
\end{tabular}




\section{Analyses of ground waters from Beaufort County}

[Anslysts: 1, Margaret D. Foster: 2 and 3, C. S. Howard; 4, C. H. Kidwell. Parts per million. Numbers at heads of columns refer to corresponding well numbers in preceding table]

\begin{tabular}{|c|c|c|c|c|}
\hline & 1 & 2 & 3 & 4 \\
\hline 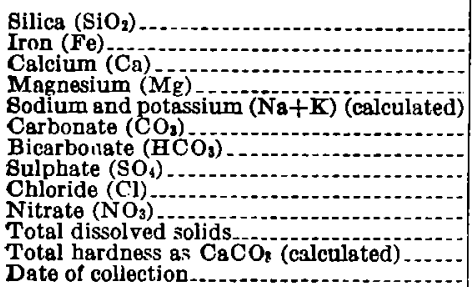 & $\begin{array}{c}29 \\
.54 \\
3.4 \\
3.7 \\
63 \\
18 \\
104 \\
3.5 \\
29 \\
\text { Trace } \\
233 \\
24 \\
\text { Nov. } 24,1917\end{array}$ & $\begin{array}{c}34 \\
20 \\
10 \\
17 \\
3.6 \\
116 \\
12 \\
4.0 \\
1.0 \\
161 \\
91 \\
\text { June } 27,1922\end{array}$ & $\begin{array}{c} \\
\\
\\
\\
27.09 \\
8.5 \\
19 \\
0 \\
145 \\
8.2 \\
5.0 \\
\text { Trace } \\
171 \\
102 \\
\text { June } 27,1922\end{array}$ & $\begin{array}{c}2.28 \\
11 \\
23 \\
8.9 \\
160 \\
4.0 \\
4.9 \\
227^{.25} \\
108 \\
\text { Nov. } 24,1917\end{array}$ \\
\hline
\end{tabular}

\section{BERRELEY COUNTY}

Few data are at hand on the underground water resources of Berkeley County. As the county lies on the south flank of the Great Carolina Ridge, the strata dip gently southward. Therefore any particular water-bearing stratum lies closer to the surface in the northern part of the county than in the southern part. It is likely that water can be found at most places at depths less than 400 feet. The table below includes all the wells of which records are on file.

Wells in Berkeley County

\begin{tabular}{|c|c|c|c|c|c|}
\hline No. & Place & Owner & 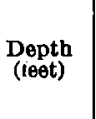 & $\begin{array}{l}\text { Diameter } \\
\text { (inches) }\end{array}$ & $\begin{array}{l}\text { Level of } \\
\text { water above } \\
\text { or below } \\
\text { surface } \\
\text { (feet) }\end{array}$ \\
\hline$\frac{1}{2}$ & Moncks Corner & Town & $\begin{array}{l}191 \\
240\end{array}$ & $\begin{array}{r}3 \\
6,4\end{array}$ & $\begin{array}{l}-16 \pm \\
-20\end{array}$ \\
\hline $\begin{array}{l}3 \\
4 \\
5\end{array}$ & $\begin{array}{l}\text { Cordesvilie } \\
\text { Cordesville, } 1 \text { mile southeast of station. }\end{array}$ & $\begin{array}{l}\text { W.K. Fishman } \\
\text { Puhlic school } \\
\text { Atlantic Lumber } \mathrm{Co}^{-}\end{array}$ & $\begin{array}{l}380 \\
300 \\
300\end{array}$ & $\begin{array}{r}41 / 2,2 \\
2 \\
3\end{array}$ & $\begin{array}{l}-15 \\
-16 \pm \\
-4\end{array}$ \\
\hline 6 & St. Stophen & John Sanders............... & $\begin{array}{l}150 \pm \\
230\end{array}$ & 2 & $-5 \pm$ \\
\hline 8 & Cross & J. C. Braddell & 407 & & -12 \\
\hline 10 & $\begin{array}{l}\text { Otranto, } 1 \text { mile northeast of } \\
\text { Near Rock Creok. } 8 \text { miles eust of } \\
\text { Eutaw ville. }\end{array}$ & $\begin{array}{l}\text { Edwin Parsons } \\
\text { F. K. Simons........... }\end{array}$ & $\begin{array}{l}918 \\
266\end{array}$ & $\begin{array}{l}41 / 2 \\
11 / 2\end{array}$ & +12 \\
\hline
\end{tabular}

The Parsons well, 1 mile northeast of Otranto (no. 9 in table), drilled in 1905, entered the Cooper marl at a depth of 20 feet and reached the bottom of the Santee limestone at 290 feet. From 290 to 870 feet it was in the Peedee formation, and from 870 to 918 feet it was in fine white glauconitic sand of either Peedee or Black Creek age. A well being drilled in January 1934 at the Berkeley County Hospital, at Moncks Corner, appeared to be in the Santee limestone at a depth of 150 feet. 
The analysis of water from the town well at Moncks Corner (no. 1) shows that it contains a moderate amount of sodium, calcium, and magnesium carbonates. The water probably comes from the Peedee formation. No water-bearing beds were noted by the driller between the bottom of the 40 -foot casing and a depth of 188 feet.

Analysis of water from town well at Moncks Corner, Berkeley County

[Analyst, O. H. Kidwell. No. 1 in preceding table] $\begin{gathered}\text { Parts per } \\ \text { million }\end{gathered}$

Iron (Fe) _... 32

Calcium (Ca)

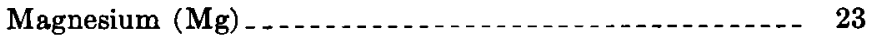

Sodium and potassium $(\mathrm{Na}+\mathrm{K})$ (calculated) $\ldots \ldots \ldots \ldots$

Bicarbonate $\left(\mathrm{HCO}_{3}\right) \ldots$

Sulphate $\left(\mathrm{SO}_{4}\right)$

Chloride (Cl)

Nitrate $\left(\mathrm{NO}_{3}\right) \ldots \ldots \ldots$

Total dissolved solids . .

Total hardness as $\mathrm{CaCO}_{3}$ (calculated) ............... 182

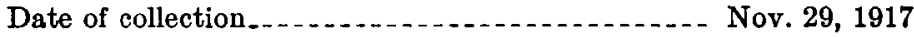

\section{CALHOUN COUNTY}

Most of the surface of Calhoun County is too high for wells to overflow, but flows can be obtained at some places in the lowlands. Water derived from the McBean formation or from the Santee limestone is likely to be hard, but that from the Tuscaloosa formation is soft. Therefore, in the southern part of the county, where the Tuscaloosa is deeply buried, water from deeper beds is likely to be better than that above it.

Wells in Calhoun County

\begin{tabular}{|c|c|c|c|c|c|}
\hline No. & Place & Owner & $\begin{array}{l}\text { Depth } \\
\text { (feet) }\end{array}$ & $\underset{\text { (inches) }}{\text { Diameter }}$ & $\begin{array}{c}\text { Level of } \\
\text { water below } \\
\text { surface } \\
\text { (feet) }\end{array}$ \\
\hline $\begin{array}{l}1 \\
2 \\
3 \\
4 \\
5 \\
6 \\
7 \\
8\end{array}$ & $\begin{array}{l}\text { St. Matthews. } \\
\text { St. Matthews, } 21 / 2 \text { miles south of } \\
\text { Cameron }\end{array}$ & $\begin{array}{l}\text { Town. } \\
\text { Arthur Baxter } \\
\text { Mrs. Charles Danzler- } \\
\text { A. P. Traywick } \\
\text { A. O. Rickenbaker... } \\
\text { S. J. Summers } \\
\text { J. R. Crouch } \\
\text { O. H. Winghes....... }\end{array}$ & $\begin{array}{r}310 \\
132 \\
285 \\
93 \\
125 \\
110 \\
135 \\
117\end{array}$ & $\begin{array}{c}8 \\
3 \\
3 \\
3 \\
21,2 \\
316\end{array}$ & $\begin{array}{r}9 \\
60 \\
90 \\
12 \\
10 \\
\text { Flows } \\
90 \\
48\end{array}$ \\
\hline
\end{tabular}

The driller of the town well at St. Matthews (no. 1, drilled in 1906), reports water at a depth between 60 and 80 feet that rose within 6 feet of the surface and a fine supply of water between 258 and 290 feet. It was necessary to use a strainer because of the loose sand. 
Analyses of ground waters from Calhoun County

[Analysts, A. A. Chambers and C. H. Kidwell. Parts per million. Numbers at heads of columns refer to corresponding well numbers in preceding table]

\begin{tabular}{|c|c|c|c|c|c|}
\hline & 1 & 6 & & 1 & 6 \\
\hline $\begin{array}{l}\text { Silica }\left(\mathrm{SiO}_{2}\right) \\
\text { Iron }(\mathrm{Fe}) \\
\text { Calcium }(\mathrm{Ca}) \\
\text { Magnesium }(\mathrm{Mg}) \\
\text { Sodium and potassium }(\mathrm{Na}+\overline{\mathrm{K}}) \\
\quad \text { (calculated) } \\
\text { Bicarbonate }\left(\mathrm{H}^{2} \mathrm{CO}_{3}\right)\end{array}$ & $\begin{array}{l}15 \\
28.07 \\
2.5 \\
86^{8.6}\end{array}$ & $\begin{array}{l}27 \\
1.0 \\
8.9 \\
2.3 \\
14 \\
19\end{array}$ & $\begin{array}{l}\left.\text { Sulphate ( } \mathrm{SO}_{4}\right) \\
\text { Chloride (Cl) } \\
\text { Nitrate (NO} \mathrm{NO}_{3} \text { ) } \\
\text { Total dissolved solids. } \\
\text { Total hardness as } \mathrm{CaCO}_{3} \text { (cal- } \\
\text { culated) } \\
\text { Date of collection, } 1917\end{array}$ & $\begin{array}{c}22 \\
3.8 \\
\text { Trace } \\
124 \\
80 \\
\text { June } 25\end{array}$ & $\begin{array}{c}40 \\
3.8 \\
\text { Trace } \\
115 \\
32 \\
32 \\
\text { June } 2\end{array}$ \\
\hline
\end{tabular}

CHARLESTON COUNTY

Flowing wells can apparently be obtained almost anywhere in Charleston County, but the water from some of them is likely to be rather highly mineralized. Wells drilled near the coast are likely to yield salty water. At Charleston there are at least three beds that yield artesian water-one in the Santee limestone at a depth of about 425 feet, another in the Peedee formation at a depth of about 1,260 feet, and a third in the Black Creek formation at 2,000 feet. The water from the Santee limestone contains much more mineral matter in solution than that from the deeper water-bearing formations.

Wells in Charleston County

\begin{tabular}{|c|c|c|c|c|c|}
\hline No. & Place & Owner & $\begin{array}{l}\text { Depth } \\
\text { (feot) }\end{array}$ & $\begin{array}{l}\text { Diameter } \\
\text { (inches) }\end{array}$ & $\begin{array}{c}\text { Level of } \\
\text { waterbelow } \\
\text { surface } \\
\text { (feet) }\end{array}$ \\
\hline 1 & Charleston, at Chisholm's mill & & 425 & & Flows \\
\hline & $\begin{array}{l}\text { Charleston, corner Meeting and Went- } \\
\text { worth Streets. }\end{array}$ & & & & \\
\hline 3 & Charleston, foot of Charlotte Street.-.- & $\begin{array}{l}\text { Charleston Consoli- } \\
\text { dated Railway \& } \\
\text { Lighting Co. }\end{array}$ & 2,001 & & Flows \\
\hline 4 & Folly Island..... & Folly Beach Amuse- & 498 & & \\
\hline 5 & 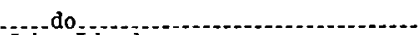 & W. F. Gholson........ & \pm 15 & & Below \\
\hline 6 & Johns Island. & A tlantic Coast Line & 417 & $\mathbf{3}$ & \\
\hline $\begin{array}{l}7 \\
8\end{array}$ & Rockville...... & $\begin{array}{l}\text { Town } \\
\text { E. B. Wilson. }\end{array}$ & $\begin{array}{r}600 \\
35\end{array}$ & 3 & $\begin{array}{l}\text { Flows } \\
\text { Below }\end{array}$ \\
\hline 9 & Dupont & H. F. Barkerding & 414 & 6 & -22 \\
\hline 10 & $\begin{array}{l}\text { Osborn } \\
\text { Drayton, } 213 \text { miles northwest of }\end{array}$ & $\begin{array}{l}\text { C. A. Gatch } \\
\text { Norwood Hasty... }\end{array}$ & $\begin{array}{l}520 \\
375\end{array}$ & 3 & $\overline{0}$ \\
\hline 12 & Meggett, 3 miles south of . ..................... & George W. Williams.. & 576 & 4162 & \\
\hline 13 & Mount Pleasant............ & C harleston-Isle of & 406 & 6 & -22 \\
\hline 14 & Isie of Palms.... & (2) & 404 & 6 & -8 \\
\hline
\end{tabular}

Artesian wells at Charleston have been described elsewhere. ${ }^{64}$

\footnotetext{
or Municipal report of the city of Charleston, S. C., 1881, artesian wells, Charleston, S. C., 1882. Ste phenson, L. W., A deep well at Charleston, S. C., with a report on the mineralogy of the water by Chase Palmer: U. S. Gool. Survey Prof. Paper 90, pp. 69-94, 1914.
} 
Analyses of ground waters from Charleston County

[Analysts: 1, William Robertson; 2, 3, Chase Palmer (U. S. Geol. Survey Prof. Paper 90, p. 93, 1915); 4 to 11 , C. S. Howard. Parts per million. Numbers at heads of columns refer to corresponding well numbers in preceding table]

\begin{tabular}{|c|c|c|c|c|c|c|}
\hline & 1 & 2 & 3 & 4 & 5 & 6 \\
\hline 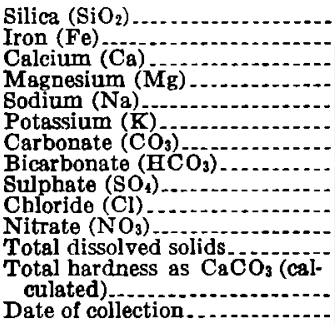 & \begin{tabular}{r}
40 \\
21 \\
31 \\
1,154 \\
146 \\
\hdashline 615 \\
271 \\
1,483 \\
3,449 \\
180 \\
1879
\end{tabular} & $\begin{array}{c}36 \\
\text { Trace } \\
14 \\
8.3 \\
1,014 \\
41 \\
41 \\
1,115 \\
\text { Trace } \\
944 \\
2,655 \\
69 \\
1912\end{array}$ & \begin{tabular}{c}
32 \\
1.0 \\
3 \\
$421^{.4}$ \\
4.4 \\
54 \\
872 \\
7.2 \\
$92^{2}$ \\
\hdashline $051^{-.2}$ \\
9 \\
1912
\end{tabular} & $\begin{array}{c}37.29 \\
18 \\
20 \\
1,250 \\
0 \\
741 \\
159 \\
1,449 \\
10 \\
3,304 \\
127 \\
\text { June } 26,1922\end{array}$ & $\begin{array}{cc} & 21 \\
& \text { Trace } \\
& 58 \\
14 \\
73 \\
0 \\
228 \\
22 \\
103 \\
2.0 \\
464 \\
\\
202 \\
\text { June } 26,1922\end{array}$ & $\begin{array}{c}32 \\
\\
4.08 \\
2.3 \\
330 \\
32 \\
526 \\
19 \\
176 \\
\text { Trace } \\
883 \\
21 \\
\text { June } 24.1922\end{array}$ \\
\hline
\end{tabular}

\begin{tabular}{|c|c|c|c|c|c|}
\hline & 7 & 8 & 9 & 10 & 11 \\
\hline 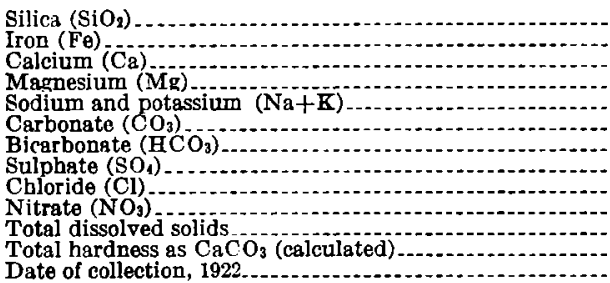 & $\begin{array}{l}42 \\
19 \\
19 \\
1,171 \\
16 \\
549 \\
86 \\
1,511 \\
\text { Trace } \\
3,185 \\
125 \\
\text { June } 24\end{array}$ & $\begin{array}{l}32 \\
44 \\
5.5 \\
46 \\
0 \\
131 \\
6.2 \\
79 \\
1.3 \\
309 \\
133 \\
\text { June } 24\end{array}$ & $\begin{array}{c}39 \\
20 \\
1.90 \\
1,281 \\
0 \\
811 \\
187 \\
1,388 \\
\text { Trace } \\
3,334 \\
58 \\
\text { June } 22\end{array}$ & $\begin{array}{c}36 \\
.09 \\
5.2 \\
1.6 \\
292 \\
28 \\
468 \\
14 \\
133 \\
\text { Trace } \\
748 \\
20 \\
\text { June } 26\end{array}$ & $\begin{array}{c}29 \\
.73 \\
8.8 \\
8.0 \\
663 \\
20 \\
733 \\
72 \\
544 \\
5.4 \\
1,719 \\
55 \\
\text { June 22 }\end{array}$ \\
\hline
\end{tabular}

- Reported as carbonate $\left(\mathrm{CO}_{3}\right)$.

\section{CHESTERFIELD COUNTY}

All but the northern part of Chesterfield County is underlain by the Tuscaloosa formation, in which plentiful supplies of soft water are to be expected. It is not likely that wells will overfow anywhere except in the lowest places. On the uplands water probably stands a considerable distance below the surface. There are said to be several flowing wells on the terraces of the Lynches River. A flowing well on a low terrace farther down the Pee Dee River at Society Hill, Darlington County, is 268 feet deep. Wells on the upland at McBee are 200 feet deep. A 779 -foot well of the Cheraw Box Co. at Cheraw appears to have entered bedrock at 135 feet; water in it stands 70 feet below the surface.

\section{CLARENDON COUNTY}

Flowing wells can probably be obtained anywhere in Clarendon County except, perhaps, in the uplands west of Summerton, which may be too high. Most of the wells are less than 500 feet deep, but in the southeastern part of the county it may be necessary to drill deeper. The water apparently comes from the Tuscaloosa formation. The mineral analyses of water from six flowing wells indicate 
that the water contains only a moderate amount of dissolved solids and that it is soft.

The well at Gable (no. 3, drilled in 1917) probably yields water from both the Black Creek and the Tuscaloosa formations. Strainers are set at depths of $326-346,366-386$, and $406-426$ feet. The

Wells in Clarendon County

\begin{tabular}{|c|c|c|c|c|c|}
\hline No. & Place & Owner & $\begin{array}{l}\text { Depth } \\
\text { (feot) }\end{array}$ & $\begin{array}{l}\text { Diameter } \\
\text { (inches) }\end{array}$ & $\begin{array}{l}\text { Level of } \\
\text { water above } \\
\text { surface } \\
\text { (feet) }\end{array}$ \\
\hline 1 & Manning & Town & 485 & 6 & 30 \\
\hline 2 & $\begin{array}{l}\text { Alcoln, th mile east of, at crossroads } 3.4 \\
\text { miles north of }\end{array}$ & $\cdots$ & 312 & & \\
\hline 3 & Gable & Black River Cypress & 457 & 6 & 10 \\
\hline 4 & $\begin{array}{l}\text { East side Black River Swamp, 1/2 mile } \\
\text { southeast of Gable. }\end{array}$ & Clarendon County & 235 & 2 & Flows \\
\hline 5 & Sardinis, $3 / 4$ mile northwest of & Malina Church....... & & & Flows \\
\hline 6 & Manning, courthouse square... & Clarendon County & 515 & 2 & $32-$ \\
\hline $\begin{array}{l}7 \\
8\end{array}$ & Manning, 6 miles east of & I. V. Plowden.......... & 446 & 2 & Flows \\
\hline$\hat{9}$ & $\begin{array}{l}\text { Alcolu, about } 5 \text { miles east of } \\
\text { Manning, } 6 \text { miles northeast of }\end{array}$ & $\begin{array}{l}\text { Ohn C. Durant } \\
\text { C. B. Geiger }\end{array}$ & $\begin{array}{l}260 \\
460\end{array}$ & 2 & $1+$ \\
\hline 10 & Summerton & C. M. Davis............ & 565 & 2 & 0 \\
\hline 11 & St. Paul & David Levi...... & 510 & 2 & Flows \\
\hline 12 & - ndo & $\begin{array}{l}\text { Clarendon Cotton Oil } \\
\text { Co. }\end{array}$ & 516 & 2 & Flows \\
\hline 13 & St Paul, 6 miles south of & Joe Sprott..... & 460 & 2 & 22 \\
\hline
\end{tabular}

contact of the Black Creek formation and the Tuscaloosa formation may come at 390 or $\mathbf{4 4 0}$ feet below the surface. A flow estimated by the driller as 250 gallons a minute was obtained from coarse sand between 430 and 440 feet. Little water was found between 440 and 457 feet, the bottom of the well.

\section{Analyses of ground waters from Clarendon County}

[Analyst, Margaret D. Foster. Parts per million. Numbers at heads of colums refer to corresponding well numbers in preceding table]

\begin{tabular}{|c|c|c|c|c|c|c|}
\hline & 1 & 2 & 3 & 4 & 5 & 11 \\
\hline 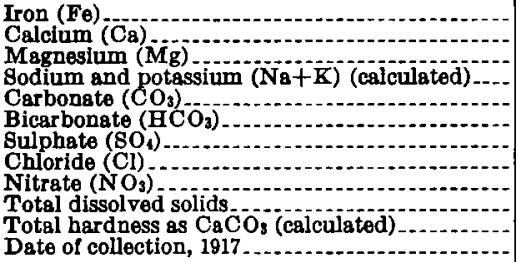 & $\begin{array}{c}0.10 \\
6.5 \\
2.1 \\
58 \\
19 \\
123 \\
9.3 \\
5.3 \\
\text { Trace } \\
224 \\
25 \\
\text { Aug. } 15\end{array}$ & $\begin{array}{l}\text { 0. } 12 \\
7.6 \\
3.3 \\
40 \\
32 \\
61 \\
10 \\
4.2 \\
208 \\
32 \\
\text { Aug. } 15\end{array}$ & $\begin{array}{l}0.21 \\
6.4 \\
2.5 \\
29 \\
13 \\
66 \\
8.6 \\
3.6 \\
143 \\
26 \\
\text { Aug. } 14\end{array}$ & $\begin{array}{c}0.08 \\
7.8 \\
2.3 \\
31 \\
19 \\
68 \\
7.0 \\
1.1 \\
\text { Trace } \\
158 \\
29 \\
\text { Aug. } 15\end{array}$ & $\begin{array}{c}0.06 \\
7.0 \\
2.6 \\
38 \\
23 \\
70 \\
8.3 \\
3.8 \\
\text { Trsce } \\
154 \\
28 \\
\text { Aug. } 14\end{array}$ & $\begin{array}{c}0.13 \\
5.7 \\
2.0 \\
53 \\
42 \\
57 \\
14 \\
4.0 \\
.24 \\
191 \\
22 \\
\text { Aug. } 11\end{array}$ \\
\hline
\end{tabular}

\section{COLIETON COUNTY}

Good water can probably be obtained anywhere in Colleton County at depths of 600 feet or less. The public water supply of Walterboro is taken from a well 560 feet deep in which the water in 1917 stood 10 or 12 feet below the surface. The water probably comes from the bottom of the Santee limestone. 
A water-bearing bed in the Tuscaloosa formation, at greater depth, underlies the northwestern part of the county and possibly extends farther south, although a well drilled to a depth of 1,515 feet at Walterboro failed to find it. This deep bed slopes from 607 feet at Smoaks to 700 feet at Miley, in Hampton County. The water is under strong pressure and in 1917 was said to flow more than 50 feet above ground at Smoaks and 40 feet at Miley. No analyses of water from this bed in Colleton County are available, but it is doubtless similar in quality to that from the same bed in Hampton-that is, soft and containing a moderate amount of sodium bicarbonate.

\section{Wells in Colleton County}

\begin{tabular}{|c|c|c|c|c|c|}
\hline No. & Place & Owner & $\begin{array}{l}\text { Depth } \\
\text { (feet) }\end{array}$ & $\begin{array}{l}\text { Diameter } \\
\text { (inches) }\end{array}$ & $\begin{array}{l}\text { Level of } \\
\text { water } \\
\text { above or } \\
\text { below sur- } \\
\text { face (feet) }\end{array}$ \\
\hline $\begin{array}{l}1 \\
2 \\
3 \\
4 \\
4 \\
5 \\
6 \\
7 \\
8 \\
9\end{array}$ & 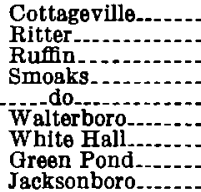 & $\begin{array}{l}\text { Town } \\
\text { Colleton Mercantile \& Manufacturing Co. } \\
\text { P. K. Crosby } \\
\text { Town } \\
\text { I. A. Bauls. } \\
\text { Town } \\
\text { Good Hope Church }\end{array}$ & $\begin{array}{r}394 \\
480 \\
94 \\
607 \\
156 \\
560 \\
230 \\
503 \\
420\end{array}$ & \begin{tabular}{c}
112 \\
412 \\
114 \\
4 \\
2 \\
6 \\
\hdashline
\end{tabular} & $\begin{array}{r}-5 \\
\text { Flows } \\
+3 \\
+50 \\
-3 \\
-12 \\
\text { Flows } \\
\text { Flows }\end{array}$ \\
\hline
\end{tabular}

Analyses of ground waters from Colleton County

Analysts: 1, C. H. Kidwell; 2, Margaret D. Foster. Parts per million. Numbers at heads of columns refer to corresponding well numbers in preceding table]

\begin{tabular}{|c|c|c|c|c|c|}
\hline & 1 & 2 & & 1 & 2 \\
\hline 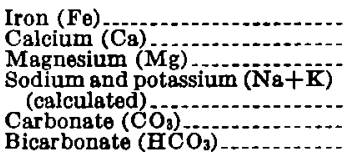 & $\begin{array}{r}0.24 \\
5.6 \\
2.6 \\
118 \\
23 \\
277\end{array}$ & $\begin{array}{l}0.15 \\
5.5 \\
3.2 \\
110 \\
51 \\
194\end{array}$ & $\begin{array}{l}\text { Sulphate (SOH) } \\
\text { Chloride (Cl) } \\
\text { Nitrate (NO3) } \\
\text { Total dissolved solids } \\
\text { Total hardness as } \mathrm{CaCO}_{3} \text { (cal- } \\
\text { culated) } \\
\text { Date of collection, } 1917\end{array}$ & $\begin{array}{c}7.2 \\
4.7 \\
346^{.56} \\
25 \\
\text { Nov. } 28\end{array}$ & $\begin{array}{c}10 \\
7.3 \\
399^{-26} \\
27 \\
\text { Nov. } 26\end{array}$ \\
\hline
\end{tabular}

\section{DARLINGTON COUNTY}

Soft water can probably be obtained from the Tuscaloosa formation anywhere in Darlington County at depths less than 500 feet below the surface. Some wells drilled in low places overflow, but wells on the uplands commonly do not overflow.

Wells in Darlington County

\begin{tabular}{|c|c|c|c|c|c|}
\hline No. & Place & Owner & $\begin{array}{c}\text { Depth } \\
\text { (feet) }\end{array}$ & $\begin{array}{l}\text { Dismeter } \\
\text { (inches) }\end{array}$ & $\begin{array}{l}\text { Level of } \\
\text { water } \\
\text { below sur- } \\
\text { face (feet) }\end{array}$ \\
\hline $\begin{array}{l}1 \\
2 \\
3 \\
4 \\
4 \\
5 \\
6 \\
7\end{array}$ & $\begin{array}{l}\text { Darlington } \\
\text { Hartsville-1il, near depot. } \\
\text { Society Hill } \\
\text { Hartsville } \\
\text { Lamar } \\
\text { Darlington }\end{array}$ & $\begin{array}{l}\text { Carolina Gas \& Elactric Co } \\
\text { Town } \\
\text { J. E. Blackman } \\
\text { Town } \\
\text { Palmetto Power \& Light Co... }\end{array}$ & $\begin{array}{l}387 \\
195 \\
287 \\
268 \\
180 \\
213 \\
318\end{array}$ & $\begin{array}{c}10 \\
6 \\
31 / 2 \\
2 \\
10 \\
8 \\
9\end{array}$ & $\begin{array}{r}30 \\
\text { Flows } \\
22\end{array}$ \\
\hline
\end{tabular}


The 10-inch town well at Hartsville, drilled in the valley of Black Creek in 1924, flows about 400 gallons a minute. The driller's log of an 896-foot well at Hartsville is given below; bedrock appears.to have been reached at a depth of 448 feet.

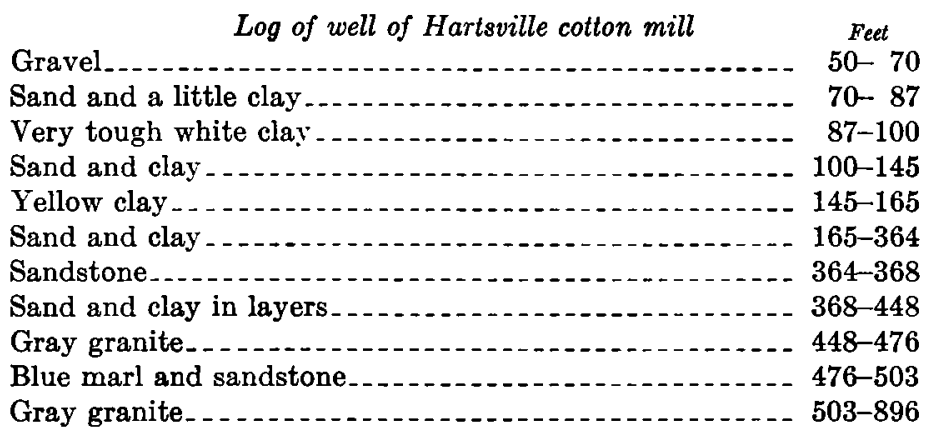

The $\log$ of a deep well drilled in 1915 for the town of Walterboro, as reconstructed from a set of badly mixed cuttings, appears to be about as follows:

Log of well of town of Walterboro

Hawthorn formation (Miocene); (probably includes some Pleistocene):

Fine yellow sand........... 0

Fine brownish-gray sand with dark phosphatic grains......... 50

Brown clay........ $50-60$

Cooper marl (Eocene):

Brownish or cream-colored marl..........- $\quad 60-\quad 530$

Santee limestone (?) (Eocene):

Gray sandy limestone, somewhat glauconitic ... $\quad 530-560$

Peedee (?) formation (Upper Cretaceous?):

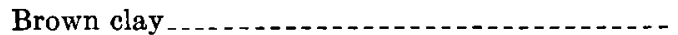

Gray sandy limestone.................... 600- 630

Gray sandy glauconitic marl _........ $630-750$

Black Creek (?) formation (Upper Cretaceous):

Chocolate-colored clay ......... $750-780$

Dirty gray sand....... $780-800$

Samples unrecognizable. . . . .

Dirty gray-brown micaceous sand; occasional plant remains ...................... 870-1,200

Dark-gray laminated carbonaceous clay ....... 1, 200-1, 500

It is not unlikely that deeper drilling at Walterboro would reach the Tuscaloosa formation, with its abundant soft water; but conditions there may be like those at Summerville, where the Black Creek formation appears to rest on Triassic rocks, the Tuscaloosa apparently being absent. 
Analyses of ground waters from Darlington County

[Analyst, A. A. Chambers. Parts per million. Numbers at heads of columns refer to corresponding well numbers in table on p. 173]

\begin{tabular}{|c|c|c|c|c|}
\hline & 1 & 2 & 3 & 4 \\
\hline 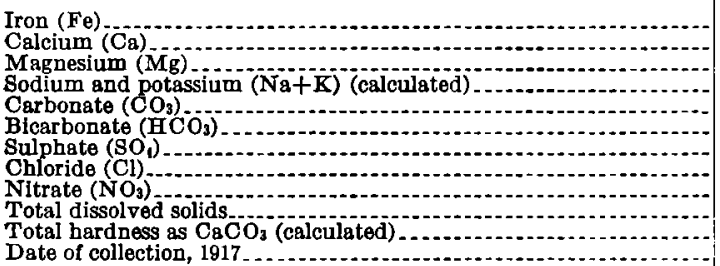 & 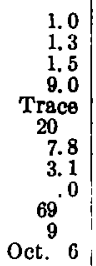 & $\begin{array}{r}6.4 \\
6.8 \\
2.2 \\
5.5 \\
1.7 \\
42 \\
7.2 \\
3.3 \\
89^{-0} \\
26 \\
\text { Oct. } 6\end{array}$ & $\begin{array}{r}\text { Trace } \\
.7 \\
.9 \\
8.4 \\
6.5 \\
8.0 \\
1.8 \\
3.1 \\
57 \\
5 \\
5 \\
\text { Oct. } 12\end{array}$ & 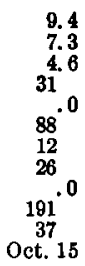 \\
\hline
\end{tabular}

\section{DILLON COONTY}

Water of excellent quality can be obtained anywhere in Dillon County within a few hundred feet of the surface. Many of the wells flow. The source of the best water is the Tuscaloosa formation.

Wells in Dillon County

\begin{tabular}{|c|c|c|c|c|c|}
\hline No. & Place & Owner & $\begin{array}{l}\text { Depth } \\
\text { (feet) }\end{array}$ & $\begin{array}{c}\text { Diameter } \\
\text { (inches) }\end{array}$ & $\begin{array}{c}\text { Level of } \\
\text { water below } \\
\text { surface } \\
\text { (feet) }\end{array}$ \\
\hline$\frac{1}{2}$ & $\begin{array}{l}\text { Dillon, 1st A venue and Main Street. } \\
\text { Hamer. }\end{array}$ & $\begin{array}{l}\text { Town } \\
\text { Atlantic Coast Lino }\end{array}$ & $\begin{array}{r}315 \\
41\end{array}$ & $\begin{array}{l}2 \\
116\end{array}$ & $\begin{array}{l}\mathbf{0} \\
3_{\text {去 }}\end{array}$ \\
\hline $\begin{array}{l}3 \\
4\end{array}$ & $\begin{array}{l}\text { Latta } \\
\text { Little Rock, } 51 \% \text { miles northwest of, } \\
\text { near Sweat Swamp. }\end{array}$ & $\begin{array}{l}\text { Railroad Co. } \\
\text { Herbert Bethea. } \\
\text { J. McQueen........... }\end{array}$ & $\begin{array}{l}204 \\
132\end{array}$ & 2 & $\begin{array}{l}\text { Flows } \\
\text { Flows }\end{array}$ \\
\hline $\begin{array}{l}5 \\
6\end{array}$ & $\begin{array}{l}\text { May, at sawmill } \\
\text { Latta, } 6 \text { miles southwest of }\end{array}$ & $\overline{\text { Jasper George.............. }}$ & $\begin{array}{l}250 \\
150 \pm\end{array}$ & 2 & $\begin{array}{l}\text { Flows } \\
\text { Flows }\end{array}$ \\
\hline $\begin{array}{l}7 \\
8\end{array}$ & Latta do & Town & $\begin{array}{l}200 \\
360\end{array}$ & & 20 \\
\hline 9 & Dillon & ....do do.............. & 265 & 13,7 & 11 \\
\hline
\end{tabular}

\section{Analyses of ground waters from Dillon County}

[Analysts: 1 and 3, Margaret D. Foster; 2 and 4, A. A. Chambers and C. H. Kidwell. Parts per million. Numbers at heads of columns refer to corresponding well numbers in preceding table]

\begin{tabular}{|c|c|c|c|c|}
\hline & 1 & 2 & 3 & 4 \\
\hline 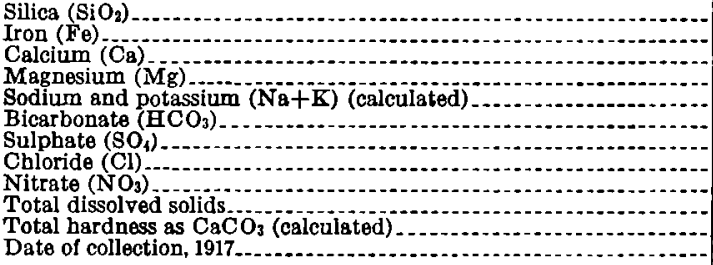 & \begin{tabular}{|l}
0.62 \\
3.4 \\
4.1 \\
32 \\
96 \\
9.0 \\
5.1 \\
Trace \\
134 \\
25 \\
Sept. 26
\end{tabular} & $\begin{array}{l}29 \\
2.1 \\
7.9 \\
1.6 \\
9.3 \\
47 \\
2.1 \\
3.9 \\
74 \\
26 \\
\text { Sept. } 26\end{array}$ & $\begin{array}{c}17 \\
0.08 \\
.6 \\
1.3 \\
11 \\
25 \\
3.1 \\
5.1 \\
45 \\
7 \\
\text { Sept. } 25\end{array}$ & $\begin{array}{c}26 \\
1.2 \\
4.8 \\
1.2 \\
15 \\
50 \\
2.8 \\
3.9 \\
.0 \\
75 \\
17 \\
\text { Oct. } 17\end{array}$ \\
\hline
\end{tabular}




\section{DORCHESTER COUNTY}

Water satisfactory for most purposes can probably be found anywhere in Dorchester County within 600 feet of the surface. Some of the wells flow. At Badham, 2 miles west of St. George, a well 540 feet deep is said to throw a jet of water 26 feet above the ground. The water, which is soft, probably comes from the Tuscaloosa formation. At Summerville the 800 -foot well of the Carolina Gas \& Electric Co. takes water from a depth of 400 feet. The water from this well contains considerably more sodium bicarbonate than that at Badham and probably comes from the Peedee formation.

Wells in Dorchester County

\begin{tabular}{|c|c|c|c|c|c|}
\hline No. & Place & Owner & $\begin{array}{l}\text { Depth } \\
\text { (feet) }\end{array}$ & $\begin{array}{l}\text { Diameter } \\
\text { (inches) }\end{array}$ & $\begin{array}{l}\text { Level of } \\
\text { water } \\
\text { above or } \\
\text { below sur- } \\
\text { face (feet) }\end{array}$ \\
\hline 1 & Ridgeville & W. B. Browning & 300 ? & $11 / 2$ & Flows \\
\hline $\begin{array}{l}2 \\
3\end{array}$ & St. George, power plent & Town & $\begin{array}{r}1,355 \\
600\end{array}$ & $\begin{array}{l}6 \\
4\end{array}$ & -12 \\
\hline 4 & Badham & Dorchester Lumber Co-. & 540 & 6 & +26 \\
\hline 5 & Reevesville, $11 / 2$ miles southeast of ... & W. F. Berry & 80 & $\cdots$ & Flows \\
\hline & Summerville.............. & $\begin{array}{l}\text { Carolina Gas \& Electric } \\
\text { Co. }\end{array}$ & 800 & & \\
\hline $\begin{array}{l}7 \\
8 \\
9\end{array}$ & $\begin{array}{l}\text { Summerville, } 11 / 2 \text { miles west of } \\
\text { do }\end{array}$ & $\begin{array}{l}\text { Mrs. H. O. Canfield } \\
\text { Town. } \\
\text { T. F. Prettyman \& Sons }\end{array}$ & $\begin{array}{l}387 \\
322 \\
360\end{array}$ & $\begin{array}{l}41 / 2 \\
8 \\
8\end{array}$ & -20 \\
\hline
\end{tabular}

Analyses of ground waters from Dorchester Cownty

[Analysts: 1, C. H. Kidwell; 4 and 6, A. A. Chambers. Parts per million. Numbers at heads of columns refer to corresponding well numbers in preceding table]

\begin{tabular}{|c|c|c|c|}
\hline & 1 & 4 & 6 \\
\hline 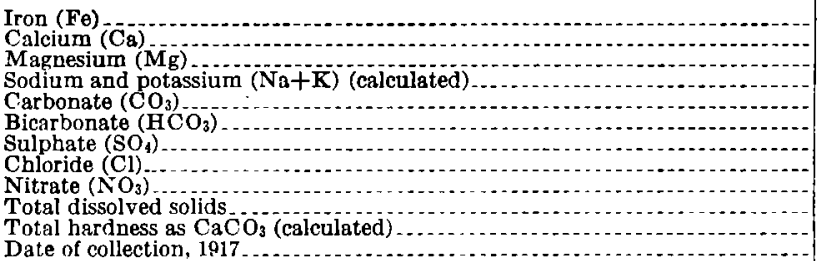 & $\begin{array}{c}0.17 \\
13 \\
9.0 \\
44 \\
16 \\
155 \\
2.7 \\
5.9 \\
\text { Trace } \\
277 \\
69 \\
\text { Dec. } 1\end{array}$ & $\begin{array}{c}0.05 \\
5.6 \\
1.4 \\
43 \\
25 \\
64 \\
12 \\
3.9 \\
\text { Trace } \\
160 \\
20 \\
\text { Dec. } 3\end{array}$ & $\begin{array}{c}0.05 \\
5.6 \\
44 \\
277 \\
34 \\
535 \\
21 \\
82 \\
1.2 \\
797 \\
32 \\
\text { Nov. } 29\end{array}$ \\
\hline
\end{tabular}

The sequence of rocks underlying the southeastern part of Dorchester County is shown by the log of an oil-prospecting well that was drilled in 1920 or 1921 at or near Summerville to a depth of at least 2,570 feet. No record was kept of the water-bearing strata penetrated. The log was constructed from cuttings submitted to the Geological Survey by M. C. Burton. The strata penetrated by the well appear to be about as follows: 
Log of oil-prospecting well at Summerville

Duplin marl (Miocene): White sandy marl ........

Hawthorn(?) formation (Miocene):

Gray clay -

Medium-fine to coarse gray gand

No sample; driller's log gives "hard shell rock"

Eocene (Cooper marl and Santee limestone):

Alternating hard and soft layers of brown granular marl containing Foraminifera, underlain by soft cream-colored limestone...........

Upper Cretaceous (Peedee formation, Black Creek(?) formation, and possibly Tuscaloosa formation):

Chiefly dark-gray gritty clay and marl; fragments of Inoceramus and Belemnitella found below $\mathbf{7 0 0}$ feet probably came from this inter-

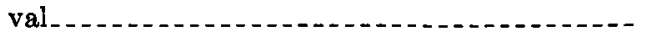

No record............

Coarse quartz sand.............

Chiefly gray or rusty sand; lignite at base 5- $^{\text {Feet }} 8$

$8-30$

$30-\quad 36$

$36-\quad 37 \frac{1}{2}$

$371 / 2-\quad 313$

313- 700

$700-\quad 727$

$727-\quad 744$

$744-1,580$

Upper Triassic(?) (Newark group?):

Coarse reddish sand; greenish clay and pyrite from core at 1,613 feet................. 1, 580-1,630

Diabase ............................... 1, 630-1, 645

Reddish shale and sandstone; rudely rounded pebbles at base . . . . . 1, 645-2, 002

Chiefly pinkish sand and gravel; gray clay from bit at 2,193 feet and red clay at 2,208 feet... 2, 002-2, 450

Diabase............................. 2, 450-2, 570

It will be noted that the Tuscaloosa formation has not been definitely recognized in this log. The interval between 313 and 700 feet seems to be the Peedee formation. The Cretaceous beds below it are probably Black Creek. If this is true, the region around Summerville may have been a hill or mountain of hard Triassic rocks that never was covered by Tuscaloosa sediments. This would have an important bearing on the ground-water possibilities of the region between Summerville and the sea,for a Triassic hill protruding through the Tuscaloosa formation would effectually dam the water in the Tuscaloosa behind it and prevent its access to the coastal region.

\section{FLORENCE COUNTY}

Flowing wells can be obtained in the southern part of Florence County and in the lowlands along streams elsewhere, but there are no records on file of flowing wells on the uplands. A 603-foot test 
well drilled in 1912 and 1913 about 2 miles east of Florence passed through the following strata:

Log of city's test well 2 miles east of Florence

Sunderland formation (Pleistocene): Chiefly red sandy clay, gravel at base; good boiler water at 20 to 22 feet; a little water between 58 and 61 feet.. Feet

Black Creek formation (Upper Cretaceous): Black shaly clay and sand.

Tuscaloosa formation (Upper Cretaceous): Light-colored micaceous sand and clay 205-603

No abundant supply of water was found in either the Black Creek or the Tuscaloosa formation in this test well, but a deeper well at Florence (city well 1) reached a water-bearing stratum in the Tuscaloosa at 650 feet. This water, as shown by the analysis, is soft and contains a moderate amount of sodium bicarbonate but not enough to be objectionable for most purposes.

Another well drilled to a depth of 1,750 feet for the city of Florence derives most of its water from a depth of 625 feet.

Wells in Florence County

\begin{tabular}{|c|c|c|c|c|c|}
\hline No. & Place & Owner & $\begin{array}{l}\text { Depth } \\
\text { (feet) }\end{array}$ & $\begin{array}{l}\text { Diameter } \\
\text { (inches) }\end{array}$ & $\begin{array}{l}\text { Level of } \\
\text { water above } \\
\text { or below } \\
\text { surface } \\
\text { (feet) }\end{array}$ \\
\hline 1 & Florence & City well 1 & $650+$ & 6 & \\
\hline $\mathbf{2}$ & $\begin{array}{l}\text { Mars Bluff, } 1.3 \text { miles south of railway } \\
\text { station. }\end{array}$ & Mars Bluff Sehool & 85 & 3 & \\
\hline 3 & Timmonsville & City well 1..- & 526 & 8 & -14 \\
\hline $\begin{array}{l}4 \\
5\end{array}$ & Elim. 3 miles west of Efingham & $\begin{array}{l}\text { City well 2. } \\
\text { C. H. Revell.-... }\end{array}$ & $\begin{array}{l}160 \\
144\end{array}$ & $\begin{array}{l}6 \\
2\end{array}$ & $\begin{array}{l}-14 \\
-13\end{array}$ \\
\hline 6 & Olanta & Town & 148 & 2 & Flows \\
\hline & $\begin{array}{l}\text { Lake City, Main Street, half a block } \\
\text { southeast of depot. }\end{array}$ & -...-_do...........- & 330 & & Flows \\
\hline $\begin{array}{l}8 \\
\theta\end{array}$ & Lake City & Imperial Tobacco $\mathrm{Co}_{-}$ & 38736 & 3 & Flows \\
\hline $\begin{array}{r}\theta \\
10\end{array}$ & Lake City, 4 miles southeast of . ........ & Garrison School........ & & & Flows \\
\hline 11 & Half Moon Bluff, Lynches River & $\begin{array}{l}\text { Mrs. A. Poston } \\
\text { S. Poston estate.......... }\end{array}$ & $\begin{array}{l}265 \\
235\end{array}$ & 2 & Flows \\
\hline 12 & Half Moon Bluff, $23 / 4$ miles south of & J. M. Eaddy & 270 & 2 & \\
\hline 13 & Mars Bluff Bridge & Bridge Board. & 90 & 2 & +14 \\
\hline 14 & Godfrey's Bridge & $\ldots . . . \mathrm{do}$ & 88 & 2 & +14 \\
\hline
\end{tabular}

Analyses of ground waters from Florence County

[Analysts: 1, 2, and 5, A. A. Chambers and C. H. Kjdwell; 3, 4, 6, 7, 9, and 10, A. A. Chambers. Parts per million. Numbers at heads of columns refer to corresponding well numbers in preceding table]

\begin{tabular}{|c|c|c|c|c|c|}
\hline & 1 & 2 & 3 & 4 & 5 \\
\hline 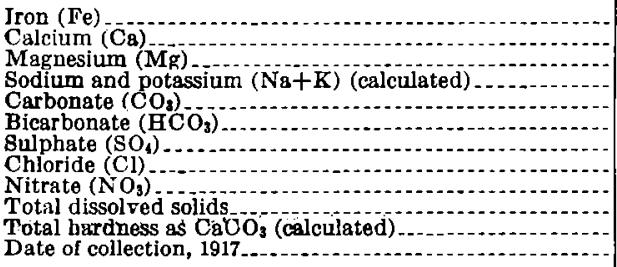 & $\begin{array}{l}0.35 \\
6.3 \\
4.4 \\
90 \\
18 \\
125 \\
17 \\
56 \\
\text { Trace } \\
295 \\
34 \\
\text { Oct. } 7\end{array}$ & $\begin{array}{l}12.27 \\
4.3 \\
.7 \\
22.0 \\
1.2 \\
12 \\
16 \\
90 \\
48 \\
\text { Oct. } 10\end{array}$ & $\begin{array}{r}4.7 \\
6.1 \\
3.0 \\
7.1 \\
47^{.0} \\
6.7 \\
4.1 \\
100 \\
28 \\
\text { Oct. } 5\end{array}$ & 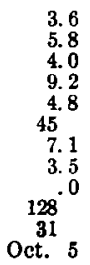 & $\begin{array}{c}2.4 \\
42 \\
9.5 \\
17 \\
\text { Trace } \\
200 \\
12 \\
3.3 \\
\text { Trace } \\
241 \\
144 \\
\text { Oct. } 4\end{array}$ \\
\hline
\end{tabular}


Analyses of ground waters from Florence County-Continued

\begin{tabular}{|c|c|c|c|c|}
\hline & 6 & 7 & $\theta$ & 10 \\
\hline 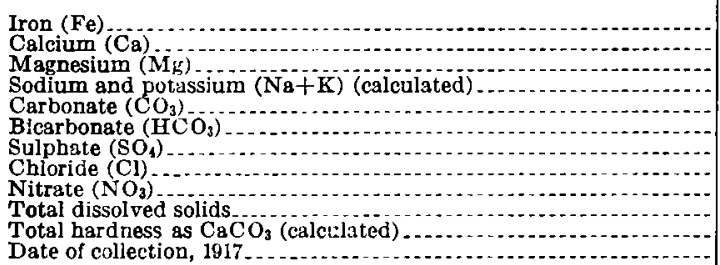 & $\begin{array}{l}0.07 \\
16 \\
5.9 \\
20 \\
25 \\
63 \\
8.5 \\
3.2 \\
187 \\
64 \\
\text { Aug. } 24\end{array}$ & $\begin{array}{l}0.06 \\
2.0 \\
1.3 \\
47 \\
34 \\
52 \\
8.7 \\
2.9 \\
\text { Trace } \\
186 \\
10 \\
\text { Aug. } 24\end{array}$ & $\begin{array}{c}0.06 \\
3.2 \\
1.4 \\
68 \\
44 \\
92 \\
8.1 \\
3.7 \\
\text { Trgco } \\
271 \\
14 \\
\text { Aug. } 24\end{array}$ & $\begin{array}{c}0.00 \\
2.8 \\
2.0 \\
121 \\
48 \\
224 \\
11 \\
1.5 \\
355 \\
15 \\
\text { Sept.12 }\end{array}$ \\
\hline
\end{tabular}

GEORGETOWN COONTY

Flowing wells can probably be obtained anywhere in Georgetown County. Most of those of which there is record are less than 600 feet deep. Water from these moderately deep wells comes from either the Peedee or the Black Creek formation and contains considerable sodium bicarbonate. It is possible that less highly mineralized water could be obtained from the Tuscaloosa formation, which presumably underlies the Black Creek in this region.

Wells in Georgetown County

\begin{tabular}{|c|c|c|c|c|c|}
\hline No. & Place & Owner & $\begin{array}{l}\text { Depth } \\
\text { (feet) }\end{array}$ & $\begin{array}{l}\text { Diamoter } \\
\text { (inches) }\end{array}$ & $\begin{array}{l}\text { Level of } \\
\text { water }\end{array}$ \\
\hline 1 & Goergetown & Crowleys & $10-15$ & Dug & \\
\hline 2 & 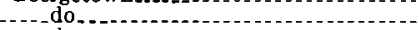 & 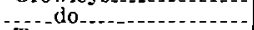 & 512 & & Flows. \\
\hline 3 & $\ldots$ do do & Town & 725 & & Do. \\
\hline 4 & Sampit & B. D. Bourne estate..- & 58916 & & Do. \\
\hline 5 & Andrews.... & 'Town & 565 & & Do. \\
\hline $\mathbf{6}$ & Rhems & F. Rhems \& Sons & 465 & & Do. \\
\hline 7 & Rhems Landing. & 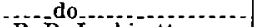 & 576 & 2 & Do. \\
\hline 8 & Waverly Mills & P. R. Lachicott $\ldots \ldots$ & $440 \pm$ & 2 & Do. \\
\hline 9 & Campfteld & O. B. Skinner & 487 & 2 & Do. \\
\hline 10 & $\begin{array}{l}\text { Ports Creek, Georgetown-Sampit } \\
\text { road. }\end{array}$ & B. W. Cannon & 536 & & Do. \\
\hline 11 & Magnolia Beach $\ldots \ldots$ & & $700 \pm$ & & Do. \\
\hline 12 & Brookgreen $\ldots$ & A. M. Huntington...- & 500 & $\ldots$ & Do. \\
\hline
\end{tabular}

Analyses of ground waters from Georgetown County

[Analyst, Margaret D. Foster. Parts per million. Numbers at heads of columns refer to corresponding woll numbers in preceding table]

\begin{tabular}{|c|c|c|c|c|c|c|c|}
\hline & 1 & 2 & $\mathbf{3}$ & 4 & 5 & 6 & 7 \\
\hline 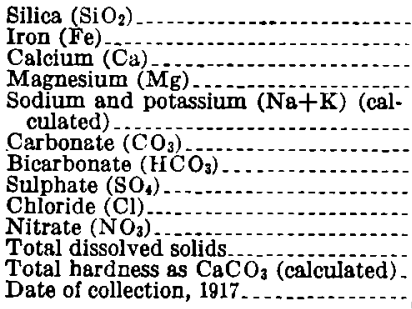 & $\begin{array}{l}62 \\
11 \\
.25 \\
\\
182^{\circ} \\
41 \\
104 \\
27 \\
462 \\
200 \\
\text { Sept. } 8\end{array}$ & $\begin{array}{l}37.18 \\
10 \\
79 \\
198 \\
39 \\
85 \\
46 \\
451 \\
188 \\
\text { Sept. } 8\end{array}$ & $\begin{array}{c}0.07 \\
3.8 \\
2.8 \\
228 \\
47 \\
486 \\
2.8 \\
26 \\
.43 \\
604 \\
22 \\
\text { Sept. } 1\end{array}$ & $\begin{array}{c}288 \\
36 \\
540 \\
18 \\
91 \\
7^{743} .35 \\
26 \\
\text { Aug. } 27\end{array}$ & $\begin{array}{c}241 \\
25 \\
463 \\
14 \\
75 \\
{ }_{627}^{.38} \\
18 \\
\text { Aug. } 31\end{array}$ & $\begin{array}{c}184 \\
47 \\
344 \\
10 \\
39 \\
.34 \\
529 \\
26 \\
\text { Aug. } 30\end{array}$ & $\begin{array}{c}197 \\
52 \\
369 \\
11 \\
42 \\
\text { Trace } \\
558 \\
33 \\
\text { Aug. } \mathbf{3 0}\end{array}$ \\
\hline
\end{tabular}




\section{HAMPTON COUNTY}

Strong flows of good water can be obtained anywhere in Hampton County at depths ranging from about 675 feet in the northern part to 1,022 feet at Garnett. Several less productive water-bearing strata are passed through before the principal stratum is reached. At Brunson two flows are piped from different depths in the same well. These waters are said to differ very slightly in chemical character, although the upper (depth 627 feet) is somewhat more highly mineralized than the lower (depth 748 feet).

The strong flows of Hampton County probably come from the Tuscaloosa formation. The formations passed through above the Tuscaloosa are, first, a few feet of Pleistocene sand; then 100 feet, more or less, of sandy or clayey Hawthorn formation; next, about 400 feet of blue or gray marl (Cooper marl and Santee limestone); and, finally, variable sand and clay, probably of Black Creek age.

The water from the deep wells in Hampton County is soft, of moderate mineral content, and satisfactory for most uses. The chief mineral constituent is sodium bicarbonate.

Wells in Hampton County

\begin{tabular}{|c|c|c|c|c|c|c|}
\hline No. & Place & Owner & $\begin{array}{l}\text { Depth } \\
\text { (feet) }\end{array}$ & $\begin{array}{l}\text { Diumeter } \\
\text { (inches) }\end{array}$ & $\begin{array}{l}\text { Level of } \\
\text { water } \\
\text { above or } \\
\text { below } \\
\text { surface } \\
\text { (feet) }\end{array}$ & $\begin{array}{l}\text { Yield } \\
\text { (gallons a } \\
\text { minute) }\end{array}$ \\
\hline \begin{tabular}{r|}
1 \\
2 \\
3 \\
4 \\
5 \\
6 \\
7 \\
8 \\
9 \\
9 \\
11 \\
11 \\
12 \\
13
\end{tabular} & $\begin{array}{l}\text { Hampton. } \\
\text { Estill } \\
\text { Scotia } \\
\text { Garnett, } \\
\text { Furman } \\
\text { Shirley } \\
\text { Fechtig } \\
\text { Crockettville- } \\
\text { Miley } \\
\text { Garnett, } 3 \text { miles west of } \\
\text { Varnville } \\
\text { Yemassee. }\end{array}$ & 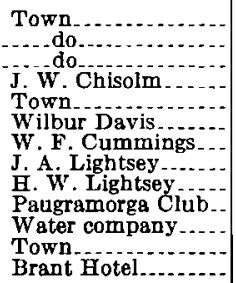 & $\begin{array}{r}832 \\
883 \\
964 \\
1,022 \\
960 \\
964 \\
400 \\
775 \pm \\
700 \\
1,000 \\
836 \\
859 \\
114\end{array}$ & $\begin{array}{l}\mathbf{4} \\
41 / 2 \\
41 / 2 \\
3 \\
416 \\
3 \\
2 \\
3 \\
3 \\
3 \\
3 \\
3\end{array}$ & $\begin{array}{r}+45 \\
+40 \\
\text { Flows } \\
\text { Flows } \\
\text { Flows } \\
\text { Flows } \\
-30 \\
\text { Flows } \\
+40 \\
\text { Flows } \\
0\end{array}$ & $\begin{array}{l}250 \\
100 \\
400 \\
150 \\
210 \\
450 \\
775 \pm \\
150 \\
200 \\
-9\end{array}$ \\
\hline
\end{tabular}

Analyses of ground waters from Hampton County

[Analyst, A. A. Chambers. Parts per million. Numbers at heads of columns refer to corresponding well numbers in preceding table]

\begin{tabular}{|c|c|c|c|c|}
\hline & 1 & 2 & 3 & 4 \\
\hline 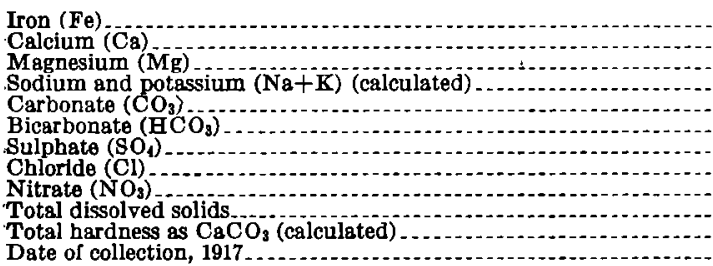 & $\begin{array}{l}0.42 \\
6.3 \\
1.3 \\
64 \\
23 \\
124 \\
13 \\
4.5 \\
216 \\
21.0 \\
\text { Nov. } 22\end{array}$ & 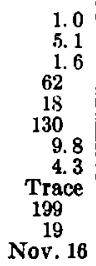 & $\begin{array}{c}0.05 \\
3.4 \\
1 \\
78 \\
33 \\
136 \\
8.4 \\
4.3 \\
.0 \\
232 \\
13 \\
\text { Nov. } 20\end{array}$ & $\begin{array}{c}0.05 \\
3.2 \\
.8 \\
82 \\
34 \\
140 \\
9.3 \\
5.5 \\
.0 \\
245 \\
11 \\
\text { Nov. } 20\end{array}$ \\
\hline
\end{tabular}




\section{HORRY COONTY}

Flowing wells can probably be obtained in Horry County anywhere within 10 or 15 miles of the coast and in the low terraces bordering the Little Pee Dee River. Elsewhere the land may be too high for wells to overflow, although water from deep wells may be expected to rise above the point of intake. The water from nearly all the wells for which analyses have been made is highly mineralized. Sodium bicarbonate is the dominant constituent in all but the 365-foot well at Loris, which contains considerable lime. It is possible that there may be less highly mineralized water in the Tuscaloosa formation, which presumably underlies the Black Creek and Peedee formations, from which the wells recorded below probably obtain their water.

Wells in Horry County

\begin{tabular}{|c|c|c|c|c|c|}
\hline No. & Place & Owner & $\begin{array}{l}\text { Depth } \\
\text { (feet) }\end{array}$ & $\begin{array}{l}\text { Diameter } \\
\text { (inches) }\end{array}$ & $\begin{array}{c}\text { Level of } \\
\text { water above } \\
\text { or below } \\
\text { surface } \\
\text { (feet) }\end{array}$ \\
\hline & Conway, at old courthouse & Town $\ldots . . . . . . .$. & \multirow{13}{*}{$\begin{array}{l}270 \\
313 \\
365 \\
350 \\
260 \\
44836 \\
300 \pm \\
365 \\
6232 \\
400 \\
270 \\
300+ \\
385 \pm \\
365 \\
235 \\
400 \\
550\end{array}$} & \multirow{12}{*}{$\begin{array}{l}11 / 6 \\
3 / 2 \\
2 \\
2 \\
2 \\
2 \\
2 \\
2 \\
113 / 2 \\
2 \\
2 \\
2 \\
2 \\
2 \\
2\end{array}$} & \multirow{9}{*}{$\begin{array}{l}\text { Flows } \\
\text { Flows } \\
+14+ \\
+25 \pm \\
+30+ \\
\text { Flows } \\
\text { Flows } \\
\text { Below } \\
\text { Below } \\
\text { Flows } \\
\text { Flows }\end{array}$} \\
\hline 3 & $\begin{array}{l}\text { Conway, at } \\
\text { Stalvey }\end{array}$ & Ed. Stalvey.. & & & \\
\hline 4 & Bucksport. & D. v. Richardso & & & \\
\hline & Toddville. & Dusenbury \& $\mathrm{Co}_{2} \ldots \ldots$ & & & \\
\hline$\frac{6}{7}$ & $\begin{array}{l}\text { Mammond } \\
\text { Hand }\end{array}$ & 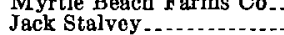 & & & \\
\hline 8 & Loris-- & Dan W. Hardwick - & & & \\
\hline 10 & Burcol. & $\begin{array}{l}\text { N. Mougly \& Collins } \\
\text { Burroughs }\end{array}$ & & & \\
\hline 11 & & ....do & & & \\
\hline 12 & Hammond... & $\mathrm{J} . \mathrm{B} . \mathrm{Cox} \ldots \ldots$ & & & \\
\hline 13 & Little River - & Sloan $\ldots . . . . .$. & & & \multirow{2}{*}{$\begin{array}{l}\text { Flows } \\
\text { Flows }\end{array}$} \\
\hline 15 & $\begin{array}{l}\text { Wrampee } \\
\text { Grea, at gin and sawmili. }\end{array}$ & J. P. Durham & & & \\
\hline 16 & & Town & & & \multirow{2}{*}{$\begin{array}{l}\text { Flows } \\
\text { Flows }\end{array}$} \\
\hline & Myrtle Beach ......... & $\begin{array}{l}\text { South Carolina Utilities } \\
\text { Co. }\end{array}$ & & & \\
\hline
\end{tabular}

Analyses of ground waters from Horry County

[Analysts: 1, 3-5, 7, 8, C. H. Kidwell; 6, Margaret D. Foster; 9, N. R. Brackett, Clemson College, South Carolina. Parts per million. Numbers at heads of columns refer to corresponding well numbers in preceding table]

\begin{tabular}{|c|c|c|c|c|c|c|c|c|}
\hline & 1 & 3 & 4 & 5 & 6 & 7 & 8 & 9 \\
\hline $\begin{array}{l}\text { Iron }(\mathrm{Fe}) \\
\text { Calcium }(\overline{\mathrm{C}} \mathrm{a}) \\
\text { Magnesium }(\mathrm{M} \mathrm{g})\end{array}$ & $\begin{array}{l}0.08 \\
3.8 \\
4.6\end{array}$ & $\begin{array}{l}0.11 \\
4.0 \\
4.1\end{array}$ & $\begin{array}{l}0.15 \\
4.6 \\
5.1\end{array}$ & $\begin{array}{l}0.20 \\
3.9 \\
5.6\end{array}$ & $\begin{array}{l}0.17 \\
4.7 \\
3.8\end{array}$ & $\begin{array}{l}0.05 \\
4.1 \\
5.2\end{array}$ & $\begin{array}{c}0.82 \\
49^{4.4}\end{array}$ & $\begin{array}{r}15.3 \\
46 \\
1.1\end{array}$ \\
\hline $\begin{array}{l}\text { Sodium and potessium } \\
(\mathrm{Na}+\mathbf{K}) \text { (calculated) }\end{array}$ & 256 & 281 & 264 & 233 & 336 & 318 & 20 & $\left\{\begin{array}{l}2 \mathrm{Na}-12 \\
3 \mathrm{~K} \\
3\end{array}\right.$ \\
\hline $\begin{array}{l}\text { Carbonate }\left(\mathrm{CO}_{3}\right) \\
\text { Bicarbonate }\left(\mathrm{H}^{2} \mathrm{CO}_{3}\right) \\
\text { Sulphate }\left(\mathrm{SO}_{4}\right) \\
\text { Chloride }\left(\mathrm{Ol}^{2}\right) \\
\text { Nitrate }\left(\mathrm{NO}_{3}\right) \\
\text { Total dissolved solids }\end{array}$ & $\begin{array}{c}41 \\
550 \\
1.8 \\
45 \\
\text { Trace } \\
676\end{array}$ & $\begin{array}{c}26 \\
647 \\
2.0 \\
43 \\
727 \\
725\end{array}$ & $\begin{array}{c}44 \\
586 \\
2.1 \\
35 \\
\text { Trace } \\
715\end{array}$ & $\begin{array}{c}45 \\
518 \\
1.2 \\
26 \\
632^{.24}\end{array}$ & $\begin{array}{l}21 \\
695 \\
2.9 \\
106 \\
\text { Trace } \\
861\end{array}$ & $\begin{array}{r}30 \\
522 \\
13 \\
163 \\
809^{.30}\end{array}$ & $\begin{array}{c}8.4 \\
195 \\
.9 \\
6.4 \\
\text { Trace } \\
245\end{array}$ & $\begin{array}{r}175.2 \\
8.0\end{array}$ \\
\hline $\begin{array}{l}\text { Total hardness as } \mathrm{CaCO}_{3} \\
\text { (calculated) }\end{array}$ & 28 & 27 & 32 & 33 & $\begin{array}{r}801 \\
27\end{array}$ & 32 & 140 & 120 \\
\hline Date of collection........ & $\left\{\begin{array}{c}\text { Sept.21, } \\
1017\end{array}\right\}$ & $\begin{array}{c}\text { Sept. 17, } \\
1917\end{array}$ & $\begin{array}{l}\text { Sept. 18, } \\
1917\end{array}$ & $\begin{array}{c}\text { Sept.17 } \\
1917\end{array}$ & Sept. 18, & $\begin{array}{l}\text { Sept. 20, } \\
1917\end{array}$ & $\underset{1917}{\text { Sept. 20, }}$ & ${ }_{1912}^{\text {July }}$ \\
\hline
\end{tabular}

1 Iron and aluminum oxides.

2 Determined. 


\section{JASPER COUNTY}

The water-bearing stratum that produces strong flows in Hampton County, the Tuscaloosa formation, is to be looked for at depths below 1,000 feet in Jasper County, but no records of wells having been drilled to it are at band. As the stratum slopes southward or soutbwestward, wells in the southern part of the county will need to be drilled deeper than those along the Hampton County line. The water may be expected to be soft and to contain somewhat more sodium bicarbonate than in Hampton County.

Moderately hard water is obtained from wells in the eastern part of Jasper County at depths ranging from less than 100 feet north of Coosawhatchie to more than 200 feet south of Old House. It probably comes from the Hawthorn formation or from the underlying Cooper marl and Santee limestone. Flows may be expected from wells drilled within 10 feet of tide level, but wells on higher land generally do not overflow.

Wells in Jasper County

\begin{tabular}{|c|c|c|c|c|c|}
\hline No. & Place & Owner & $\begin{array}{l}\text { Depth } \\
\text { (feet) }\end{array}$ & $\begin{array}{c}\text { Diameter } \\
\text { (inches) }\end{array}$ & $\begin{array}{l}\text { Level } \\
\text { of water } \\
\text { above or } \\
\text { below } \\
\text { surface } \\
\text { (feet) }\end{array}$ \\
\hline $\begin{array}{l}1 \\
2 \\
3\end{array}$ & $\begin{array}{l}\text { Coosawbatchie } \\
\text { Old House, } 2.2 \text { miles south of } \\
\text { old House, } 6 \text { miles east of Ridge- }\end{array}$ & $\begin{array}{l}\text { R. T. W. Roberts } \\
\text { P. A. Cooler } \\
\text { T. L. Smith. }\end{array}$ & $\begin{array}{l}106 \\
196 \\
230\end{array}$ & $\begin{array}{l}21 / 2 \\
2 \\
3\end{array}$ & $\begin{array}{l}\text { Flows } \\
-21 / 2 \\
+2\end{array}$ \\
\hline $\begin{array}{l}4 \\
5\end{array}$ & $\begin{array}{l}\text { Ridgeland } \\
\text { Hardeeville, } 3 \text { miles north of }\end{array}$ & $\begin{array}{l}\text { Town } \\
\text { Camp P64, Civilian Con- } \\
\text { servation Corps. }\end{array}$ & $\begin{array}{l}385 \\
275\end{array}$ & $\begin{array}{l}(?) \\
(?)\end{array}$ & $\begin{array}{l}-40 \\
+11 / 4\end{array}$ \\
\hline
\end{tabular}

Analyses of ground waters from Jasper County

[Analysts: 1, C. H. Kidwell; 2, C. S. Howard. Parts per million. Numbers at heads of columns refer to corresponding well numbers in preceding table]

\begin{tabular}{|c|c|c|c|c|c|}
\hline & 1 & 2 & & 1 & 2 \\
\hline $\begin{array}{l}\text { Silica }\left(\mathrm{SiO}_{2}\right) \\
\text { Iron }(\mathrm{Fe}) \\
\text { Calcium }(\mathrm{Ca}) \\
\text { Magnesium }(\mathrm{Mg}) \\
\text { Sodium and potassium }(\mathrm{Na}+\overline{\mathrm{K}}) \\
\text { (calculated) } \\
\text { Carbonate }\left(\mathrm{CO}_{3}\right) \\
\left.\text { Bicarbonate } \mathrm{HCO}_{3}\right)\end{array}$ & $\begin{array}{l}0.06 \\
26 \\
7.5 \\
22 \\
4.3 \\
148\end{array}$ & $\begin{array}{l}35 \\
44 \\
7.8 \\
8.6 \\
0 \\
185\end{array}$ & $\begin{array}{l}\text { Sulphate }\left(\mathrm{SO}_{1}\right) \\
\text { Chloride }(\mathrm{Cl}) \\
\left.\text { Nitrate (NO})_{3}\right) \\
\text { Total dissolved solids } \\
\text { Total hardness as } \mathrm{CaCO} \text { (cal- } \\
\text { culated) } \\
\text { Date of collection }\end{array}$ & $\begin{array}{c}4.9 \\
6.3 \\
\text { Trace } \\
209 \\
96 \\
\left\{\begin{array}{c}\text { Nov.23 } \\
1917\end{array}\right.\end{array}$ & $\begin{array}{c}3.5 \\
5.0 \\
\text { Trace } \\
203 \\
\\
142 \\
\text { June } 27 \\
1922\end{array}$ \\
\hline
\end{tabular}

\section{KERSHAW COUNTT}

The sands of the Tuscaloosa formation, which underlies the southern and southeastern parts of Kershaw County, may be expected to yield a plentiful supply of pure, soft water. Wells are not likely to overflow except in the lowlands along the larger streams. There are several flowing wells across the Lynches River in Chesterfield County. 
Big Spring, on the west bank of the Lynches River near Bethune, is said to flow 350 gallons a minute. Its water doubtless comes from the Tuscaloosa formation. The spring was granted by George III to James Briggs in 1756.

\section{LEE COUNTY}

Water of good quality can probably be obtained from the Tuscaloosa formation anywhere in Lee County within 400 feet of the surface. Wells in the higher parts of the county need to be pumped, but flows have been obtained in the low southern part. A flowing well near the Sumter County line south of St. Charles is said to be 170 feet deep. Mrs. Moneyham's flowing well, 0.7 mile south of the station at Lynchburg, is said to be 380 feet deep. The town well at Bishopville is 8 and 6 inches in diameter and 286 feet deep. The following analysis of water from this well shows that its content of mineral matter is exceptionally low.

Analysis of water from town well used for public water supply of Bishopville

[Well 286 foet deep. Sample collected Aug. 6, 1917; analyzed by Margaret D. Fọster]

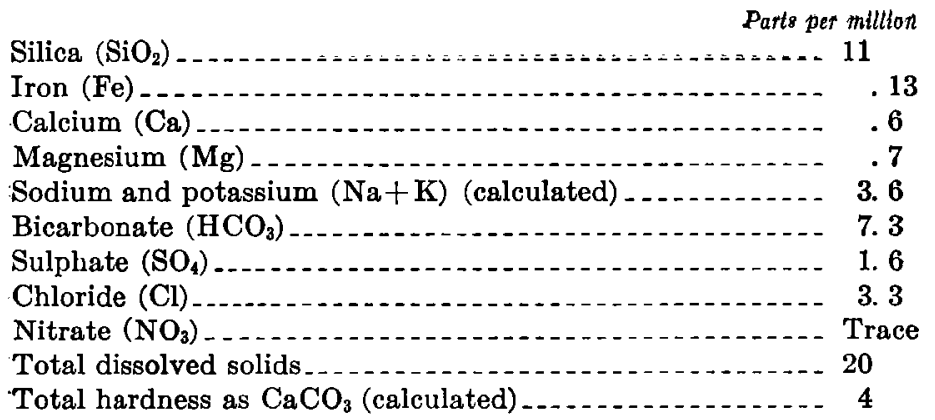

LEXINGTON COUNTY

Lexington County lies partly within the Coastal Plain and partly within the Piedmont province. The sandy soils of the Coastal Plain serve as excellent storage reservoirs for the rain that falls on them and may be expected to yield plentiful supplies of good water. Flows are not to be expected, except possibly in the lowlands along the rivers and larger streams. Water in wells on the uplands probably will not rise much above the level of the bed in which it occurs. The best water will probably be found in the Tuscaloosa formation.

At Pelion dug wells range from 20 to 60 feet in depth, and some bored wells are as deep as 125 feet. The depth of the water table varies with the rainfall. Wells south of Pelion range in depth from 40 to 60 feet. The 2-inch well at the Swansea public scbool is 42 feet deep. A well on the property of W. T. Smith, 3 miles north of Swansea, is 247 feet deep. 


\section{MARION COUNTY}

All the wells noted in Marion County probably derive their water from the Black Creek formation. The water from most of them contains a moderate amount of sodium bicarbonate. The three wells at Marion are interesting in that the chemical quality of the water in each differs from that of the others. The water from the 300 -foot well contains calcium bicarbonate and is slightly hard; that from the 200 -foot well is soft and contains sodium bicarbonate; and that from the 150-foot well is much more highly mineralized that the others and contains calcium sulphate, or gypsum. It is possible that better water could be obtained from deeper wells drilled into the Tuscaloosa formation. A 1,200-foot well at Marion yields water that makes a rusty stain.

Wells in Marion County

\begin{tabular}{|c|c|c|c|c|c|}
\hline No. & Place & Owner & $\underset{\text { (feet) }}{\text { Depth }}$ & $\begin{array}{l}\text { Diameter } \\
\text { (inches) }\end{array}$ & $\begin{array}{l}\text { Level of } \\
\text { water }\end{array}$ \\
\hline $\begin{array}{l}1 \\
2 \\
3 \\
4 \\
5 \\
6 \\
7 \\
8\end{array}$ & $\begin{array}{l}\text { Marion, well 1... } \\
\text { Marion, well 2 } \\
\text { Marion, well 3 } \\
\text { Marion, } 13 \text { miles south of } \\
\text { Nicholas, } 200 \text { feet north of station. } \\
\text { Peedee, st store... } \\
\text { Mullins.... } \\
\text { Marion... }\end{array}$ & $\begin{array}{l}\text { Carolina Light \& Power Co... } \\
\text { Friendship Baptist Church. } \\
\text { Public } \\
\text { A. P. Chambliss } \\
\text { Town }\end{array}$ & \begin{tabular}{c}
300 \\
200 \\
$150+ \pm$ \\
150 \\
\hdashline 240 \\
375 \\
1,200
\end{tabular} & $\begin{array}{c}6 \\
6 \\
8 \\
2 \\
-2 \\
8\end{array}$ & $\begin{array}{c}\text { Flows. } \\
\text { Do. } \\
\text { Do. } \\
\text { Do. }\end{array}$ \\
\hline
\end{tabular}

Analyses of ground waters from Marion County

[Analysts: 1, 2, 5, 6, A. A. Chambers and C. H. Kidwell; 3, 4, Margaret D. Foster. Parts per million. Numbers at heads of columns refer to corresponding well numbers in preceding table]

\begin{tabular}{|c|c|c|c|c|c|c|}
\hline & 1 & 2 & 3 & 4 & 5 & 6 \\
\hline 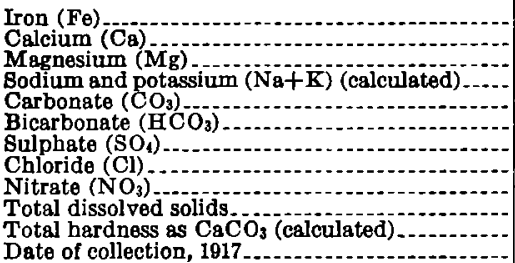 & $\begin{array}{l}0.22 \\
22 \\
3.7 \\
12 \\
8.2 \\
89 \\
2.4 \\
4.9 \\
163 \\
70 \\
\text { Sept. } 27\end{array}$ & $\begin{array}{c}0.13 \\
4.4 \\
3.0 \\
50 \\
18 \\
114 \\
1.6 \\
5.3 \\
\text { Trace } \\
220 \\
23 \\
\text { Sept. } 27\end{array}$ & $\begin{array}{l}0.35 \\
91 \\
8.6 \\
18 \\
5.3 \\
59 \\
228 \\
5.1 \\
\text { Trace } \\
481 \\
263 \\
\text { Sept. } 27\end{array}$ & $\begin{array}{c}0.12 \\
7.8 \\
3.9 \\
83 \\
24 \\
164 \\
13 \\
19 \\
\text { Trace } \\
289 \\
35 \\
\text { Sept. } 25\end{array}$ & $\begin{array}{c}0.09 \\
1.8 \\
1.9 \\
40 \\
\text { Trace } \\
102 \\
4.3 \\
7.3 \\
\text { Trace } \\
161 \\
12 \\
\text { Sept. } 24\end{array}$ & $\begin{array}{c}0.08 \\
2.4 \\
1.0 \\
51 \\
13 \\
105 \\
4.6 \\
6.1 \\
\text { Traco } \\
189 \\
10 \\
\text { Oct. I }\end{array}$ \\
\hline
\end{tabular}

\section{MARLBORO COUNTY}

An abundance of water of low mineral content can be obtained almost anywhere in Marlboro County at shallow depths. Water from the Pleistocene gravel, which lies near the surface, is more liable to pollution than deeper water from the Tuscaloosa formation.

Wells in Marlboro County

\begin{tabular}{|c|c|c|c|c|c|}
\hline No. & Place & Owner & $\begin{array}{l}\text { Depth } \\
\text { (feet) }\end{array}$ & $\begin{array}{c}\text { Diameter } \\
\text { (inches) }\end{array}$ & $\begin{array}{l}\text { Level of } \\
\text { water }\end{array}$ \\
\hline $\begin{array}{l}1 \\
2 \\
3 \\
4 \\
\mathbf{5}\end{array}$ & $\begin{array}{l}\text { Bennettsville (6 wells) } \\
\text { Bennettsville (2 wells) } \\
\text { Bennettsville } \\
\text { Blenheim, at swamp level. } \\
\text { MeColl }\end{array}$ & $\begin{array}{l}\text { Town } \\
\text { Blenbeim Bottling Works. } \\
\text { Town }\end{array}$ & $\begin{array}{r}60 \\
40 \\
31 \\
35 \\
100\end{array}$ & $\begin{array}{l}41 / 2 \\
412 \\
412 \\
2 \\
3\end{array}$ & Flows. \\
\hline
\end{tabular}




\section{Analyses of ground waters from Marlboro County}

[Analysts: 1, 2, Margaret D. Foster; 3, 4, C. H. Kidwell; 5, A. A. Chambers. Parts per million. Numbers at beads of columns refer to corresponding well numbers in preceding table]

\begin{tabular}{|c|c|c|c|c|c|}
\hline & 1 & 2 & 3 & 4 & 5 \\
\hline 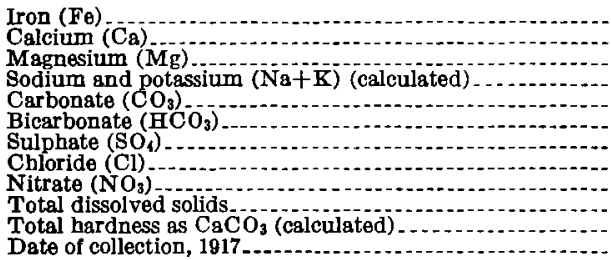 & $\begin{array}{l}0.09 \\
1.8 \\
13 \\
18.0 \\
1.6 \\
12 \\
4.3 \\
66^{.3} \\
\text { Oct. }^{.} 20\end{array}$ & $\begin{array}{l}0.08 \\
1.1 \\
1.7 \\
12.0 \\
22.0 \\
1.7 \\
8.4 \\
6.5 \\
70 \\
10 \\
\text { Oct. } 20\end{array}$ & $\begin{array}{c}0.04 \\
1.6 \\
12.1 \\
23.0 \\
.9 \\
5.1 \\
7.4 \\
80^{6} \\
\text { Oct. } 20\end{array}$ & $\begin{array}{l}0.50 \\
1.0 \\
12.9 \\
23.0 \\
5.8 \\
4.5 \\
\text { Trace } \\
72 \\
6 \\
\text { Oct. } 16\end{array}$ & $\begin{array}{r}\text { Trace } \\
0.8 \\
1.0 \\
11 \\
7.7 \\
10 \\
1.4 \\
3.9 \\
1.2 \\
53 \\
6 \\
\text { Oct. } 17\end{array}$ \\
\hline
\end{tabular}

ORANGEBURG COONTY

Water can be obtained at moderate depth anywhere in Orangeburg County. Deep wells generally pass though several water-bearing beds, some of which will yield flows almost anywhere in the southeast half of the county and in the lower parts of the northwest half. Water taken from the Cooper marl, the Santee limestone, or the McBean formation is more or less hard because it has dissolved some of the lime from them; but that taken from the Tuscaloosa formation, which is reached by many of the deeper wells, contains some sodium bicarbonate and is soft.

Wells in Orangeburg County

\begin{tabular}{|c|c|c|c|c|c|}
\hline No. & Place & Owner & $\begin{array}{l}\text { Depth } \\
\text { (feet) }\end{array}$ & $\begin{array}{l}\text { Diam- } \\
\text { eter } \\
\text { (inches) }\end{array}$ & $\begin{array}{l}\text { Level of } \\
\text { water } \\
\text { above or } \\
\text { below sur- } \\
\text { face (feet) }\end{array}$ \\
\hline 1 & Orangeburg, bank of Edisto Rive & Town & 186 & 8 & +20 \\
\hline 2 & Orangeburg, power plant....... & do & 220 & 2 & Flows \\
\hline 3 & Felder, $1 / 2$ mile east of....... & Mary C. Dibble & 9316 & $11 / 4$ & \\
\hline 4 & Holly Hill & J. H. Wiggins & 255 & 2 & -35 \\
\hline $\mathbf{5}$ & do & Town & 105 & $\overline{2}$ & -3 \\
\hline 6 & Eutaw ville & do & 772 & 6 & Flows \\
\hline $\begin{array}{l}7 \\
8\end{array}$ & Belvedere plantation, below Eutaw & $\begin{array}{l}\text { Mrs. W. H. Koopman } \\
\text { Charles Sinkler. }\end{array}$ & $\begin{array}{l}279 \\
312\end{array}$ & 3 & $\begin{aligned}-23 \\
\text { Flows }\end{aligned}$ \\
\hline $\mathbf{9}$ & $\begin{array}{l}\text { Springs. } \\
\text { Eutaw ville, } 1 \text { mile east of }\end{array}$ & W. L. Dolason. & 265 & 3 & -32 \\
\hline 10 & Orangeburg, 1 mile east of & C. A. Stroman. & 200 & 3 & -1 \\
\hline 11 & Elloree, $1 / 2$ mile nor theast of. & J. K. Ulmer & $90 \pm$ & 3 & Flows \\
\hline 12 & Jamison & R. E. Wannamaker- & 190 & & -60 \\
\hline 13 & $\begin{array}{l}\text { Etheridge Mill, } 3.3 \text { miles north-north- } \\
\text { east of. }\end{array}$ & L. $\bar{K}$. Etheridg $\theta . . .$. & 300 & 3 & Flows \\
\hline 14 & Branchville & Jennings \& Harvely... & 500 & 3 & +50 \\
\hline 15 & Neeses, 7 miles northwest of. & Rocky Grove School.... & 110 & 2 & -50 \\
\hline 16 & Norway, 4 miles west of & F. F. Bell & 122 & 2 & Below \\
\hline 17 & Livingston & Arthur Fogel. & 170 & 2 & -70 \\
\hline 18 & 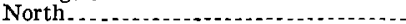 & Town & 110 & 2 & -40 \\
\hline 19 & $\begin{array}{l}\text { Ninety-six Road, } 3 \text { miles west of Edisto } \\
\text { River. }\end{array}$ & L. G. Way & 365 & 3 & -100 \\
\hline
\end{tabular}


Analyses of ground waters from Orangeburg County

[Analysts: 5, C. H.Kidwell; the rest by A. A. Chambers and C. H. Kidwell. Parts per million. Numbers at heads of colums refer to corresponding well numbers in preceding table]

\begin{tabular}{|c|c|c|c|c|c|c|c|c|}
\hline & 1 & 5 & 6 & 7 & 11 & 15 & 16 & Spring 1 \\
\hline Silica $\left(\mathrm{SiO}_{2}\right)_{\ldots} \ldots$ & & 29 & 28 & 35 & 30 & 8. 0 & 26 & \\
\hline $\begin{array}{l}\text { Iron }(\mathrm{Fe}) \\
\text { Calcium }(\mathrm{Ca}) \\
\text { Magnesium (Mg) }\end{array}$ & $\begin{array}{l}0.06 \\
48 \\
3.4\end{array}$ & $\begin{array}{l}46^{.07} \\
2.4\end{array}$ & $\begin{array}{l}.09 \\
4.4 \\
1.8\end{array}$ & $15^{.23}$ & $\begin{array}{l}38^{.20} \\
2.6\end{array}$ & $\begin{array}{l}.33 \\
1.4 \\
1.7\end{array}$ & $28^{.08}$ & $\begin{array}{c}0.07 \\
44 \\
2.9\end{array}$ \\
\hline $\begin{array}{l}\text { Sodium and potassium(Na+ } \\
\text { K) (calculated) } \\
\text { Carbonate (CO }\end{array}$ & 11.0 & $\stackrel{13}{2.6}$ & $\begin{array}{r}102 \\
14\end{array}$ & $\begin{array}{r}17 \\
5.3\end{array}$ & ${ }_{6.5}^{11}$ & 14.0 & $\begin{array}{l}5.1 \\
.0\end{array}$ & $\begin{array}{c}8.7 \\
\text { Trace }\end{array}$ \\
\hline Bicarbonate $\left(\mathrm{HCO}_{3}\right)$ & 171 & 164 & 237 & 87 & 123 & 43 & 103 & 154 \\
\hline $\begin{array}{l}\text { Sulphate }\left(\mathrm{SO}_{4}\right) \\
\text { Chloride (Cl) }\end{array}$ & 11 & $\begin{array}{l}5.3 \\
5.7\end{array}$ & $\begin{array}{r}15 \\
4.0\end{array}$ & $\begin{array}{l}9.6 \\
4.6\end{array}$ & ${ }_{4.5}^{11}$ & $\begin{array}{l}1.8 \\
2.8\end{array}$ & $\begin{array}{l}2.0 \\
3.0\end{array}$ & $\begin{array}{l}\text { 4. } 0 \\
6.1\end{array}$ \\
\hline Nitrate $\left(\mathrm{NO}_{3}\right)$ & Trace & Trace & .20 & Trace & Trace & Trace & Trace & 1.9 \\
\hline $\begin{array}{l}\text { Total dissolved solids } \\
\text { Total hardness as } \mathrm{CaCl}_{3}\end{array}$ & 209 & 180 & 284 & 132 & 165 & 49 & & 197 \\
\hline $\begin{array}{l}\text { (calculated) } \\
\text { Date of collection, } 1917 .\end{array}$ & $\begin{array}{l}134 \\
\text { June } 28\end{array}$ & $\begin{array}{l}125 \\
\text { Dec. } 2\end{array}$ & $\stackrel{18}{\text { June } 27}$ & $\begin{array}{c}60 \\
\text { June } 27\end{array}$ & $\begin{array}{l}106 \\
\text { June } 25\end{array}$ & $\begin{array}{l}10 \\
\text { July } 14\end{array}$ & $\begin{array}{l}80 \\
\text { July } 14\end{array}$ & $\begin{array}{l}122 \\
\text { Dec. } 2\end{array}$ \\
\hline & & & & & & & & \\
\hline
\end{tabular}

1 At Eutaw Springs.

RICHLAND COUNTY

The porous sand of the Tuscaloosa formation, which underlies all of Richland County except the northern and northwestern parts, may be expected to yield an abundance of water of excellent quality. It is not likely that wells will flow except in the lowlands along the Wateree and Congaree Rivers. Wells at Eastover and Congaree are said to be 480 and 100 feet deep, respectively.

\section{SUMTER COUNTY}

Records indicate that flows can be obtained almost anywhere in the east half of Sumter County at depths less than 200 feet below the surface. Most of the wells probably tap the Tuscaloosa formation. Wells drilled in the higher parts of the county will not overflow. In 1917 the city of Sumter owned 13 wells ranging in depth from 55 to 60 feet, two wells 427 feet deep, and one 430 feet deep. Water stood 15 feet below the surface in the deep wells and 4 to 21 feet below the surface in the shallow wells, varying with the rainfall.

At Mayesville four flowing wells range in depth from 200 to 250 feet. Surface water there is found at a depth of about 18 feet. There are other water-bearing beds at 30,65 , and 160 feet.

At Pocalla Springs there are six 2-inch flowing wells ranging in depth from 192 to 324 feet. In 1917 the strongest was reported to yield 78 gallons a minute, the others about 52 gallons. One of them had a head of $21 \frac{1 / 2}{2}$ feet with reference to the surface. The temperature of the water is reported to be $663_{2}^{\circ} \mathrm{F}$. 
Wells in Sumter County

\begin{tabular}{|c|c|c|c|c|c|}
\hline No. & Place & Owner & $\begin{array}{c}\text { Depth } \\
\text { (feet) }\end{array}$ & $\begin{array}{l}\text { Dismeter } \\
\text { (inches) }\end{array}$ & $\begin{array}{l}\text { Level of } \\
\text { water } \\
\text { above or } \\
\text { below } \\
\text { surface } \\
\text { (feet) }\end{array}$ \\
\hline $\begin{array}{l}\mathbf{1} \\
\mathbf{2} \\
\mathbf{3} \\
\mathbf{4} \\
\mathbf{5} \\
\mathbf{6} \\
\mathbf{7} \\
\mathbf{8} \\
\mathbf{9}\end{array}$ & $\begin{array}{l}\text { Mayesville. } \\
\text { Mayesville, } 216 \text { miles southeast of.- } \\
\text { Mayesville, } 2 \text { miles west of, near } \\
\text { Les County line. } \\
\text { Mayesville. } \\
\text { Mayesville, } 1 \text { mile north of } \\
\text { Lynchburg, } 5.4 \text { miles south of } \\
\text { Sumter } \\
\text { Cane Savannah, } 2 \text { miles south of.- }\end{array}$ & $\begin{array}{l}\text { Town } \\
\text { Sadie MuIdrow } \\
\text { G. G. Cooper estate.... } \\
\text { R. A. Chandler } \\
\text { E. L. Cooper, } \\
\text { W. W. Cunningham... } \\
\text { Sumter Ice \& Fuel Co.-- } \\
\text { Camp Miller, Civilian } \\
\text { Conservation Corps. }\end{array}$ & $\begin{array}{r}160 \\
+184 \\
96 \\
160 \\
170 \\
480 \\
60 \\
205 \\
125\end{array}$ & $\begin{array}{r}2 \\
3 \\
2 \\
2 \\
3 \\
2 \\
10 \\
2\end{array}$ & $\begin{array}{r}\text { Flows } \\
\text { Flows } \\
\text { Flows } \\
\text { Flows } \\
\text { Flows } \\
0 \\
\text { Below }\end{array}$ \\
\hline
\end{tabular}

Analyses of ground waters from Sumter County

[Analysis: 1, Margaret D. Foster; 2, A. A. Chambers and C. H. Kidwell. Parts per million. Numbers at heads of columns refer to corresponding well numbers in preceding table]

\begin{tabular}{|c|c|c|c|c|c|}
\hline & 1 & 2 & & 1 & 2 \\
\hline $\begin{array}{l}\text { Iron (Fe) } \\
\text { Calcium (Ca) } \\
\text { Magnesium ( } \mathrm{Mg} \text { ) } \\
\text { Bodium and potassium }(\mathrm{Na}+\mathrm{K}) \\
\text { (calculated) } \\
\text { Carbonate }(\mathrm{CO})_{3} \\
\text { Bicarbonate }\left(\mathrm{HOO}_{3}\right)\end{array}$ & $\begin{array}{r}3.3 \\
6.8 \\
2.8 \\
7.2 \\
3^{.0}\end{array}$ & $\begin{array}{l}0.36 \\
10.8 \\
65^{11}\end{array}$ & 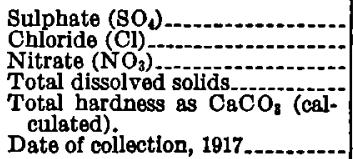 & $\begin{array}{c}12 \\
3.2 \\
\text { Trace } \\
88 \\
28 \\
\text { Aug. } 7\end{array}$ & $\begin{array}{r}9.7 \\
3.0 \\
\text { Trace } \\
116 \\
45 \\
\text { Aug. } 3\end{array}$ \\
\hline
\end{tabular}

\section{WIIIAMSBURG COUNTY}

Most of the deep wells of Williamsburg County derive their water from either the Black Creek formation or the Peedee formation, both of which are of Upper Cretaceous age. The water from these formations contains some sodium bicarbonate in solution and is soft. An exception to this is the 65-foot well at Lane (no. 3 in the tables below), which contains considerable lime and may represent a mixture of waters from the Eocene Santee limestone and the Peedee formation. It is possible that water containing less mineral matter can be obtained from the Tuscaloosa formation in wells deeper than those reported.

Wells in Williamsburg County

\begin{tabular}{|c|c|c|c|c|c|}
\hline No. & Place & Owner & $\begin{array}{l}\text { Depth } \\
\text { (feet) }\end{array}$ & $\begin{array}{l}\text { Diameter } \\
\text { (inches) }\end{array}$ & $\begin{array}{l}\text { Level of } \\
\text { water } \\
\text { above } \\
\text { surface } \\
\text { (feet) }\end{array}$ \\
\hline 1 & Kingstree...... & Town... & 450 & 3 & \\
\hline $\mathbf{2}$ & 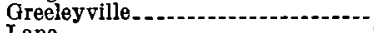 & do do & 428 & $\cdots$ & Flows \\
\hline $\begin{array}{l}3 \\
4\end{array}$ & $\begin{array}{l}\text { Lane } \\
\text { Morrisville, } 144 \text { miles northwest of }\end{array}$ & $\begin{array}{l}\text { S. S. Aaronson } \\
\text { F. Rhems \& Sons }\end{array}$ & $\begin{array}{r}65 \\
432\end{array}$ & $\cdots \cdot$ & Below \\
\hline & railroad station. & & & & Flows \\
\hline $\mathbf{5}$ & Nesmith, 4.6 miles west of .... & R. D. Gamble_................... & 408 & & Flows \\
\hline 6 & Nesmith & W. L. Marlowe_.............. & 448 & 2 & Flows \\
\hline 8 & Hemingway, $23 / 4$ miles north-north- & W. L. MeDaniel & 285 & 1 & $\begin{array}{l}\text { Flows } \\
\text { Flows }\end{array}$ \\
\hline 9 & Rome, 714 miles south of.......... & W. C. Hemingway \& Co... & 377 & & Flows \\
\hline 10 & Kingstree, 6 miles northwest of...... & St. Marys Church & 440 & 2 & $18+$ \\
\hline 11 & Kingstree & Town & 564 & 6 & 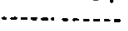 \\
\hline & Kingstree, 4 miles south of & $\begin{array}{l}\text { Camp P62, Civilian Con- } \\
\text { servation Corps. }\end{array}$ & 552 & 134 & $\cdots \cdot \cdots$ \\
\hline 13 & Johnsonville. & & 60 & & Below \\
\hline
\end{tabular}




\section{Analyses of ground waters from Williamsburg County}

[Analysts: 1-6, A. A. Chambers; 7-9, C. H. Kidwell. Parts per million. Numbers at beads of columns refer to corresponding well numbers in table preceding]

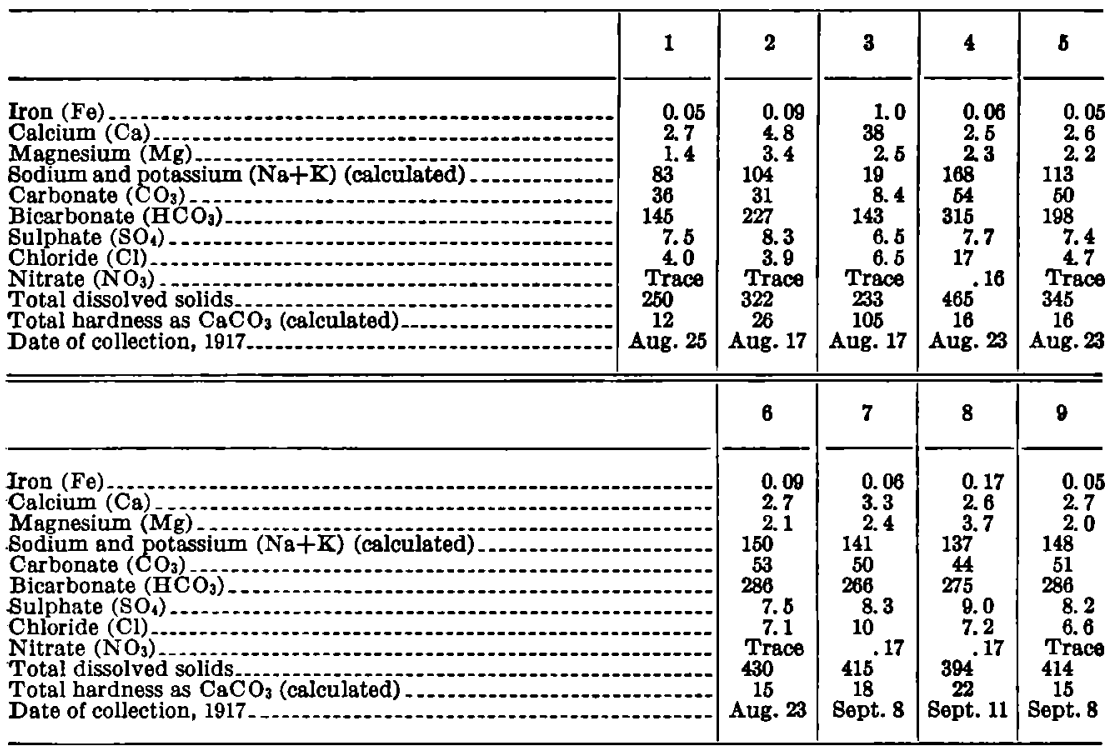




\section{INDEX}

\section{$\boldsymbol{A}$}

Abstract

Ackerman formation, correlation of ......... 40

Aiken, section at................... 24, 93, pl. 15, $A$

Aiken County, formations in .... 24-25, 57-59,93-95 ground water in...................... 164-165 well records.

Aiken Plateau, features of . .........- $9-10$, pl. 11, $A$ A lachua formation, correlation of............ 123

Allendale County, formations in.- 88-89, 91, 136-137 ground water in ....................... 165-166 well records.

Alum Bluff group, correlation of.

Analyses, of ground water. See particular counties.

of marl 113-114

Anderson Bridge. 119,144 Appalachia, position of

Aquia formation, correlation of

Arca zone, correlation of.

Ariels Crossroads, section at

Ashby place.

Ashley marl, use of name..... 74-75, 83, 101, 113-115

Ashley marl works, section at_........... 113-114

Ashley River, features of.................... 13 sections along .......... 87-88, 113-114, pl, 14, $B$

Atkins................... 140

Atlantic Plain, extent of................. 3

\section{B}

Bacons Bridge

Baldock $88-89$

Bamberg County, formations in.. 60-61, 89, 137-138 ground water in

Barnwell buhr sands, use of name.......... 89

Barnwell County, Barnwell sand in........ 91-92 ground water in........................ 166-167 well records ............................ 166

Barnwell sand, character and relations of.... 72 , 89-91, pls. 15, 16, $A$ description of, by counties............. 91-95 fossils in, list of ............................ 94-95 water in

Barrier besches, occurrence of......... 7-8, pl. 17

Barton...................................... 137

Bashi formation, correlation of............... 40

Bates Mill, sections at.............. 53-54, pl. 14, $A$

"Bays" in Horry County ................... 7, pl. 17

Beaches, features of

Bear Bluff.......................................... 127

Bear Branch................................. 137

Beaufort County, formations in

ground water in....................... 167-168 well records

Besutiful Gate Church...................- 136

Beaver Creek, section on.
Beech Bank.

Page

Bees Ferry ............................ 87,88, 115

Belle Broughton plantation, $\log$ of well and fossils on

Belleville Road, section on

Bellewood School.................................. 59

Benneckers Bridge, section at .............. 60-61

Bennett Swamp, fossils found near.......... 47

Bennettsville_............................... 143

Berkeley County, formations in .......... 48,

$79-80,83-85,122,129-130,144$

ground water in....................... 168-169

well records . . . .

Bethel Church, exposures and fossils near.... 95 ,

pl. 16, $A$

Beulah Church, section near.................. 85-86

Big Beaver Creek, section on .......... 62

Big Branch................................... 141

Big Bull Swamp........................... 81-82

Big Poplar Creek......... 81

Big Spring-................................ 21, 183

Biggin Swamp. . . . ......................... 13, 83-84

Bighorse Creek, exposure on.............. pl.12, $A$

Bishopville, analysis of water from.......... 189 exposures near............................. 134

Black Creek, outcrops and fosslls on......... 25, 28

Black Creek formation, character and relations of.......-25-27, pls. 12, $B, 13, A$ description of, by counties............. 27-32 fossils in, lists of................. 28-27, 29-30, 31

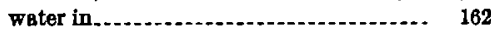

Black Mingo Creek, exposures and sections along ........................ 37, 43-44

general relations of ..................... 12

Black Mingo formation, character and relations of ............. 41-42, pl. 14, $A$

description of, by counties............... 43-55

fossils in, lists of $\ldots . . . . \ldots \ldots . . . \ldots . . . . . .42,49,51$

water in............................... 163

Black River, fossils found along..... 44-45, 128-129 general relations of ...................... 11, 12 sections along-......... 38, 43-46, 128-129, 134, 140

Blenheim, section at......................... 142

Bohicket phese, use of name................ 151

Bolton phosphate mine, Johns Island, section

at. ......................... 115, 151

Bone Valley gravel, correlation of............ 123

Bonneau ....................................... 48

Bostick Landing, section at ...........-.. 119-120

Brackett, N. R., analyses by ................ 181

Brandywine formation, character and rela. tions of

water in ................................... 164

Brandywine terrace, features of ............. 9

Brandywine time, land and sea in............ pl. 10 
Brewington Lake, section near. .... Page

Brick Church . . . .

Bristow.......................................... 142

Broad River, general relations of ............ 11, 130

Browns Ferry, sections at.................... 38

Broxton Ford, section at................... 112

Brunson's mill................................ 48

Bryn Mawr gravel, correlation of

Bucatunna clay member, correlation of...... 97

Buck Swamp, sections on ............ 31,147

Bucksport_..................................... 153

Bucksville

Buhrstone formation, use of name.......... 55,89

Bull Swamp road, sections on ............... 61-62

Bullhesd Run............................. 84

Bulliopsis quadrata zone, correlation of ....... 100

Burches Ferry, section and fossils at.....- 30, 33-34

Burches Ferry phase, use of name............ $\quad 32$

Byram marl, correlation of................. 97

Cains Landing, section at

Calcareous marl, deposits of $159-160$

Calhoun County, formations in............. 23-24, $53-54,66-72,82,138$

ground water in ...........- 169-170 well records.......................... 169

Calico Spring, section at...................... $\quad 93$

Caloosahatchie marl, correlation of........... 123

Calvert formation, correlation of

Cancellaria zone, correlation of................ 100

Cape Fear formation, beds formerly referred

to........... 19,20

Captains Creek

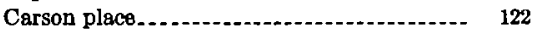

Cartersville_............................ 119, 141

Cashua Ferry road, exposures on $21,25,27,28,140$

Castle Hayne marl, correlation of............. 40

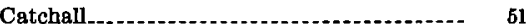

Caw Caw Swamp, sections near........... 62-63,66

Cedar Springs (Bamberg County)

Cedar Springs (Berkeley County) -...-.-..... 122

Chambers, A. A., analyses by ........ 165, 166, 167, $170,175,176,178,180,184,185,180,187,188$

Charleston, formations underlying -.-.-.-. 151-152

Charleston County, formations in........ 87-88,

$114-115,151-152$

ground water in .................... 170-171

well records . . ......................... 170

Charleston Navy Yard, section at..........-. 87

Charleston waterworks, exposures at........ 84

Charlton formation, correlation of ............ 123

Chat tahoochee formation, use of name....... 99

Cheraw cobbles, correlation of .............. 123

Chesapeake Bay in Pliocene time............ 123

Chesterfleld County, formations in ground water in ......................... 171

Chickasawhay marl member, correlation of -- $\quad 97$

Chipola formation, correlation of .......... 100

Chisolms Island........... 111

Choctawhatchee formation, correlation of -.- 100

Choppee Creek............................. 44

Choptank formation, correlation of......... $\quad 100$

Chowan formation, use of name . . .......... $\quad 149$

Citronelle formation, correlation of .......- 123
Claiborne group, correlation of.........-..... 40

Clarendon County, formations in......... 48-49,

78-79, 138-139, 144

ground water in .......................- 171-172

well records............................ 172

Clay, deposits of

Clayton formation, correlation of............. 40

Clio .......................... 143

Coal, absence of.............................. 161

Coal Bluff beds, correlation of ........... 40

Coastal Plain, general features of............- 2-3

of South Carolina, "bays" on divisions of.................. 3-11 geologic map of......... pl. 2 (in pocket) streams of . . . .

Coastal terraces, description of........ 4-9, 130-154

ideal profle across..................... 6

origin and extent of................... 4-6,

130,157, pl. 1 (in pocket)

Cocoa sand member, correlation of........- 40

Coffee sand member, correlation of .......... 16

Cohansey sand, possible correlation of .....-. 100

Coharie formation, character and relations of - 132

description of by countias

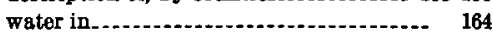

Coharie terrace, features of...................

Coharie time, land and sea in.............. p

Cohens Bluff.................................... 98

Coker Spring-................... 93

Colleton County, formations in..........- 111-113,

$116-117,138,143$

ground water in......................... 172-173

well records_........................... 173

Columbia-Camden highway, exposures along- 23

Combahee River, course of................ 13

Combabee shale, use of name......... 101, 107, 112

Concord Church

Congaree River, fossils found along

general relations of....................... 11, 130

Congaree sand hills, features of ........... 11

Congaree shale, type locslity of............... 59-60 use of name ......................... 41-42,71

Continental Shelf, boundaries of.............- 3

Continental warping..................... 154-157

Cook Mountain formation, correletion of.... 56

Cooper marl, character and relations of ..... $\quad 72$,

$82-83$, pl. $14, B$

description of, by counties..._._. $83-89$

fossils in, list of...................... 85

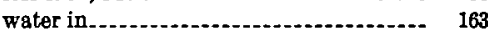

Cooper River, fossils found along ...... 122, 129, 130 general relations of ...................... 13

section on

Cooper River marls, use of name........... 74-75

Coosawhatchie River, course of

Copper, absence of

Coquina, occurrence of ................... 153, 154

Correlation, of Eocene formations............ 39-40 of Miocene formations................... 99-100 of Oligocene formations......... 96-97 of Pleistocene formations. ................ 131 of Pliocene formations................ 123 of Upper Cretaceous formations . . ....... 15-16 of Vicksburg group...................... 96-97 
Page

Cottingham Creek

County line road between williamsburg and Georgetown Counties, exposures on.

37,44

Coxs Bridge, sections near.................... 57-58 Crassatellites meridionalis zone, correlation of 100 Creston, sections and fossils near.......... 68-69,82 Croatan sand, correlation of................ 123

Cypress Swamp, general relations of......... 13

\section{D}

Dall, W. H., quoted $126-127$

Darlington, fossils collected near. section at................................. 140

Darlington County, formations in $27-28,121,133-134,140$

ground water in ......................... 173-175 well records . . . .

Davis Landing, soctions and fossils at ..... . 35-36,

120,144

Dawsons Landing

110

Dean Hall

Deep Creek

Delaware Bay in Pliocene time.............. 123

Dewitts Landing, sections at....... $35,145, \mathrm{pl}, 13, B$

Dibble farm, section and fossils on.- 94-95, pl. 15, $B$

Dillon County, formations in..........- 19,142,147 ground water in...................... 175

well records. .................... 175

Dividers, The

Doctor Lake................................... 78

Dorchester County, formations in.......... 85-87, $113-114,122-123,138,148$ ground water in. ..................... 176-177 well records. ............. 176

Draingge of the area, courses of principal streams...- 11-13

development of...... 13-14, 130, 154-155, 156-157

Drayton-................ 88, 115

Drowned valleys...................... 123, 130, 157

Duck Creek

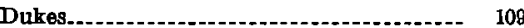

Dunbar.

Dunbarton Bridge............................ 147

Dunes, occurrence of

Duplin marl, character and relations of ...... 117-

118 , pl. $16, B$ ....... 119-123 fossils in water in............. 164

\section{$\mathbf{E}$}

Early Branch, fossils found on, list of 63-65

Earthquake of 1886

East Branch of Cooper River, exposures slong.

Ebenezer Church

Ebenezer Landing

109

Ecphora zone, correlation of

Edisto marl, fossils in.................. 103-104, 106 phosphate deposits of ...... 103-104, 113-114, 159 use of name............ 101, 102, 106, 113, 114, 115

Edisto River, features of...................... 12-13 fossils found along . ................. 116-117 sections along. $60-61,85-87,112-113,116-117,138$

Effingham, sectlons and fossils near.. 36-37, 119, 141
Ellenton, analysis of water from exposures near...... 57

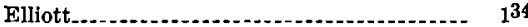

Englishtown sand, correlation of

Enochs Wood Landing ..................... pl. 16, $B$

Eocene epoch, conditions during......... 155-156

Eocene series, correlation of................... 39-40 description of

Etheridge Mill, section near................... $61-6^{2}$

Eureks mill pond........................... 20

Eutaw formation, correlation of ........... $1^{6}$

Eutaw Springs, fossils found at............... 80-81

Eutawville............ 81

Evans Bluff, section at...................... 128-129

Exogyra costata zone, correlation of........... 16

Ezooyra ponderosa zone, correlation of....... 16

F

Fair Spring................................... 79-80

Fairfield, Santee River...................... 153

Fall Line, position of

Farrell's mill .................. $\quad 92$

Fechtig, $\log$ of well at.................. 110

Fellowship Branch......................... $\quad 139$

Ferguson

Flint River formation, correlation of........- 97, 98

description of............................ $88-98$

water in ................................ 163

Five Chop Road, exposure on............ 135

Florence, formations near................... 28, 142

$\log$ of city's test well near................ 178

Florence County, formations in .........-.- 28-30, $33-37,112-120,141-142,144-146,148$

ground water in

well records.............................. 178

Floyd's mill, section at

Folly Island, shifting of shore line on....... 6, pl. 3

Forest Hill sand, correlation of ............ 87

Forestville_................................ 144

Fort Motte_............... 23, 69

Fossils. See particular formations.

Foster, M. D., analyses by ............. 166, $168,172,173,175,179,181,183,184,185,187$

Four Hole Swamp, section at...._........... 86, 148

Frogmore . . ................................ 151

Frying Pan Landing

Fuller's earth, deposits of.................... 160

Fuller's Earth Creek. .................

\section{a}

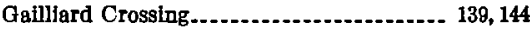

Garners Ferry road, exposures on ........... 52-53

Gas, conditions unfavorable for............... 161

Gaston, section and fossils near................ 59-60

Geographic provinces of the area.............. 2-3

Geography of the area.................... 2-14

Geologic formations of the area, correlation of. 16 ,

$40,97,100$

descriptions of

list of

maps showing............ pls. 1, 2 (in pocket)

Geologic history of the srea................. 154-157

Georgetown, formations underlying......... 153

Georgetown County, formations in.......... 37-38,

43-44, 127-130, 152-153

ground water in........................... 179

well records........................... 179 


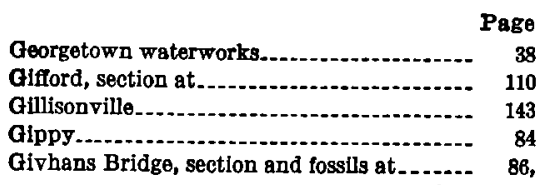

$122-123,148$

Glacial epoch. See Pleistocene epoch.

Glendale Spring

Glendon limeston

Gold, absence of cortation of............. 9

Good Hope Church $\ldots . . . . . . .52$

Goose Creek, fossils found on............ 84, 129-130

Gosport s8nd, correlation of ............... 40

Gourdin......................................... 47

Great Carolina Ridge, general relations of _ 99,158

Great Carolinian bed of marl, use of name... 74

Grenada formation, correlation of ........... 40

Griggs Landing . . ........................... 113

Ground water in the area, analyses of. see particular countles.

description of, by counties

164-188

quality of

161-164

sources of

162-164

Grove, The

129,130

\section{H}

Hagins Prong

143

Helfway Swamp, sections and fossils on $24,68-69,82$

Hamburg, section at 24-25

Hamburg formation, use of name

Hampton County, ground water in

Haw thorn formation in

17

well records 180

Hanging Rock-..................... 46

Hardee Ferry

Harpers Landing ....................... 39, 126

Hartsville, exposures near............ 21-22, 133-134

Hartsville cotton mill, log of well of.......... 174

Hatchetigbee formation, correlation of.....-. 40

Hawthorn formation, character and relations of description of, by counties........ 104-115 fossils in, lists of marl in, analyses of water in

$163-164$

Haw thorne, exposures near.................- 94

Heinemann ................................. 47

Hicks Landing -............................... 122

High Hill Creek (Calhoun County), sections on

High Hill Creek (Darlington and Florence Counties) . ........................ 28, 142

High Hills of Santee, features of .............. 10

Hixons Bridge, sections neer...... 57

Hodge's mill _............................... 30-31

Holly Springs sand, correlation of .......... 40

Hornerstown marl, correlation of .......... 40

Horrell Hill. ................................. 23, 53

Horry County, aerial photographs of part of.. pl. 17 formations in ................. 39, 125-127, 153-154 ground water in well records................. 181

Howard, C. S., analyses by............. 168, 171, 182 Hudson River, changes of sea level affecting.. 123,
Hudsons Ferry Landing, Ga., sections near.. 104106, pl. 16, $B$

Huspa Creek 111

Ingleside $84-85$

Intracoastal Waterway, fossils from

Iron-bearing minerals, lack of economic value

Isgat's mill, section at

21

\section{$\mathbf{J}$}

Jackson formation, correlation of. ........ 40,72-73

Jasper County, formations in.............. 110, 143

ground water in ........................ 182

well records. . . .

Jenkins Hill ............................. 81-82

Johns Island, section at.................... 115, 181

Johnsons Landing.......................... $\quad 91$

Johnsonville............................. 148

\section{$\mathbf{K}$}

Kaolin, deposits of .................... 160-161

Kennedy's Scarp..... 58

Kershaw County, ground water in........ 182-183

Tuscalooss formation in . ............... 22

Kidwell, C. H., analyses by.. 166, 167, 168, 169, 170, $173,175,176,178,181,182,184,185,186$, $187,188$.

Killian ................... 23

Kings Creek phase, use of name............. 98

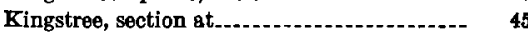

Kirkland Creek, section on

Kirkwood formation, correlation of .......... 100

Kosciusko sandstone member, correlation of. $\quad \mathbf{4 0}$

$\mathbf{L}$

Lambs, section at................ 87-88, pl. 14, $B$

Lane. .......................................... 78

Lang Syne beds, type locality of

use of name.................... 41

Lang Syne plantation, sections on ........ 53, 69-70

Langley, Tuscaloosa formation near.- 24, pl. 12, $A$

Laurance Bridge, section at.................- 141

Laurel Hill, beds and fossils at. ............ 151-152

Lee County, formations in .... 22, 51-52, 134-135, 140 ground water in

Leesville...................................... 95

Lemon Creek . . . . .

Leneuds Ferry, section at..................... 77-78

Lowisfield.............................. 84

Lexington County, formations in ...... 24,59-60,05 ground water in. ........................ 183

Lightsey place-.-.......-... 110

Lignite, occurrence of

Limestone, deposits of .................... 159-160

Limestone Creek, section on...................

Lisbon formation, correlation of........... 40

Little Limestone Creek, section near........ $\quad 65$

Little Pee Dee River, features of............ 12 formations exposed along....... 19, 120-121, 142

Little River, exposures and fossils on........ 125

Little River Inlet, fossils near................

Lonestar . . . . . . . . .

Long Island Sound in Pliocene time........... 123 
Page

Louthers Lake.

Lower Black Mingo, type locality of use of name.

Lower Three Runs.

Lower Warley Hill shales, use of name......

Lumber River, course of.

Lyell, Charles, quoted.

Lynches Lake

Lynches River, features of

Lyons Creek, exposures on.............. 67-68

\section{M}

Magnolia Gardens.......................... 88, 115 Magothy formation, correlation of .......... 16, 18

Manasquan marl, correlation of............. 40

Manning .............................. 48-49, 139

Manning-Kingstree road, exposures on...... $\quad 47$

Marianna limestone, correlation of

Marine formations, description of ........ 130-154

Marion, formation underlying.-............. 146

Marion County, formations in .............. 30-31, $120-121,142,146-147$ ground water in .................... 184 well records................................ 184

Marion-Sellers road, exposure on........... 146

Marks Head marl, fossils in ............... 102-103 type locality of, and sections nearby -- 106-108, pl. 16, $B$ use of name............................ 101

Marks Head Run, section on............ 106

Marl, analyses of............................ 113-114 occurrence of . ................... 159-160 See also Cooper marl; Duplin marl; Raysor marl.

Marl Lake, section at..................... 108

Marlboro County, formations in.- 20, 133, 142-143 ground water in. ........................ 184-185 well records.................. 184

Mars Bluff, sections and fossils at........... 28-30, 146 , pl. 12, $B$

Marshalltown formation, correlation of...... 16

Matawan group, correlation of........... 16

Mayesville............................... 139-140

Mazyck place.......................... 79-80

McBean formation, character and relations of $55-56$,

description of, by counties.

pl. 14, $A$

fossils in, lists of water in................................. 163

$\mathrm{McBee}$

McCowans Mill._...... 140

Mechanicsville, sections near............. 27-28, 134

Merchantville clay, correlation of............- 16

Meredith..................................... 134

Metallic ores, sbsence of

Meteorite scars, so-called.................. 7, pl. 17

Middendorf, exposures near.............. 20, pl. 11, $B$

Middendorf formation, fossils in.......... 18, 22, 24 type locality of........... 20, pls. 11, $B, 12, A$ use of name_..................... 17

Middle Swamp............................ 121, 142

Midway group, correlation of

Milepost 19, section near.

Mill Swamp.
Mint Spring marl member, correlation of...- 97

Miocene epoch, conditions during-..-.-.-... 99,156

Miocene series, correlation of ............... 99-100 description of ........... 101-123

Moncks Corner, analysis of water from.....- 169 marl near.

Moncks Corner-St. Matthews road, exposures on

Monmouth group, correlation of............. 10

Moodys marl member, correlation of........ $\quad 40$

Moore's Spring

Mount Hope marl, use of name........... 75, 81

Mount Laurel sand, correlation of.......... 16

Mount Pleasant Landing, section at_-...-...- 108

Mouzon Bridge, section near.................. 46

Mullins-Smithboro road..................-...-. 147

Murrays Ferry road, exposures on........ $37,47,48$

Myers Hill, section at. ..................... 34-35

Myers Landing, section at................. 119, 145

Myrtle Beach, formation exposed at.......... 153

fossils found on....... 39

wave action on .............................

$\mathbf{N}$

Naheola formation, correlation of ............ 40

Naked Creek

Nanafalia formation, correlation of ........... 40

Nanjemoy formation, correlation of .........- 40

Navesink marl, correlation of ............... 16

New Bridge........... 62

Nichols, section at............................. 146-147

Nixons Landing -......................... 39

Norfolk series of soils.

\section{0}

Oak Grove sand, correlation of................ 100

Ocala limestone, correlation of

Oil, conditions unfavorable for................ 161

Oligocene epoch, conditions during.-...... 96

Oligocene series, correlation of............... 96-97

description of........... $98-89$

Orangeburg, sections and list of fossils at ... 65-66,

135-136

Orangeburg County, formations in $80-82,135-136,138,144$

ground water in ......................... 185-186

well records

Orangeburg formation, type locality of ....... 69

use of name-.... 65

Orangeburg series of soils..................... $\quad 90$

Ore deposits, absence of .................. 159

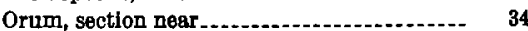

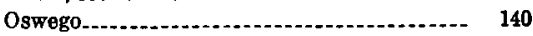

Ox Swamp $\ldots$

\section{$\mathbf{P}$}

Palmer, Chase, analyses by

171

Pamlico formation, character and relations of -................................. 149-150

description of, by counties............ 150-154

water in................................. 164 Pamlico terrace, features of.............. 6-7, pl. 17

Pamlico time, land and sea in............... pl. 4

Pamunkey group, correlation of.............. $\quad \mathbf{4 0}$

Parachucla marl, use of name_........ 101, 106, 107

Parachucla shale, use of name............ 101,

$106,107,110,111,112$ 


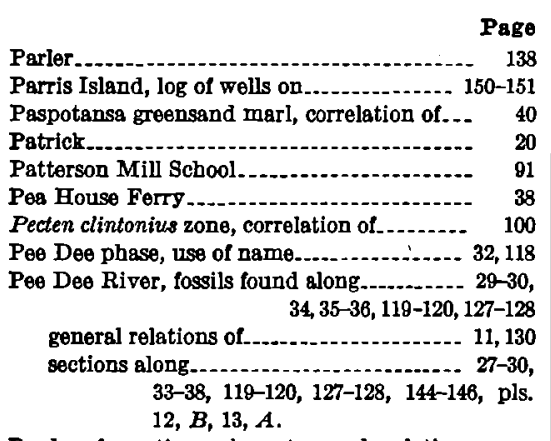

Peedee formation, character and relations of

description of, by counties.............. 32-39

fossils in, lists of ........................ 34,36

water in............ 162-163

Pelion-Woodford road, section on............. 59

Penholoway formation, character and relations of

description of, by counties............... 148

water in................ 164

Penholoway terrace, features of

Penholoway time, land and sea in........... pl. 6

Perkins Bluff, section at.................... 43

Perkins Landing

Petersfield

Petroleum, conditions unfavorable for

Phillip's mill............................... 61

Phosphate deposits, nature and distribution of

Physical geography of the area................ 2-14

Pinckney Landing ..................... 81

Pinewood......... 135

Piscataway indurated marl member, correlation of.

Platinum, absence of

Pleasant Grove School.

Pleistocene epoch, climate o South Carolina during.

relations of sea and land during 157

13-14, 130. 157, pls. 4-10, 17

Pleistocene series, character and relations of $130-131$ description of .............................. 130-154 map showing -................. pl. 1 (in pocket) water in

164

Pllocene epoch, conditions during........... 13, $123-124,156-157$

Pliocene series, character and relations of.- 123-124 description of .......................... 123-130

Pocalls Springs_............................... 51, 140

Pocotaligo

Pocotaligo River........................... 12, 51

Ponpon................................. 114

Pooser's Hill............................ 63, 64, 65

Pooshee.............. 80

Poplar Creek............................... 81

Poplar Spring

Porcher plantation............................ 122

Port Royal, log of wells near.................. 150

Porters Creek clay, correlation of............. $\quad 40$

Porters Landing, sections at and near....... 100-108

Ports Creek................................... 153

Potapaco clay member, correlation of........ $\quad 40$
Page

Potato Creek

Price's Creek.................................... 154

Pudding Swamp............................ 12

Purysburg, section at........................ 109

$\mathbf{R}$

Rancocas group, correlation of.............. 40

Raritan formation, correlation of ............. 16, 18

Raysor Bridge, section and fossils near..... 116-117

Raysor marl, definition of . .................. 115-116

fossils in, list of .

section of ..................... 110

water in .............................. 164

Red Bluff................................. 127

Red Bluff clay, correlation of .............. $\quad 97$

Red Hill

Red Landing, Louthers Lake_.............. 28

Redbank sand, correlation of................. 16

Rhems Landing, section at . ................. 43-44

Rhems shale, use of name.................... 41

Richland County, formations in ......... 23, 62-53 ground water in...................... 186

Richland red hills, features of

Ripley formation, correlation of............... 10

Robertson, William, analyses by............ $\quad 171$

Rock Spring. ............................ 78

Rocky Point ................................. 22, 31

Rocky Swamp........................... 61

Rogers, G. S., quoted....................... 83

Rowe's Mill Branch, section on............. 45

Royal Ferry.................................. 127

Ruffin, Edmund, quoted................. 74

Runnymede................................... 115

S

St. Andrews mine

St. Charles.................................. 134

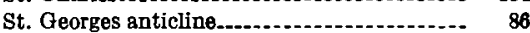

St. Helena Island .........-................. 151

St. Marys formation, correlation of .....- $\quad 100$

St. Matthews, sections near............... 54,66-67

St. Maurice formation, correlation of ....... 56

St. Stephen

Salkehatchie phase, use of name........... 101, 114

Salkebatchie River, general relations of...... 13

section on.......................... 111-112

Salley

Salters_............................................ 45

Saluda River, general relations of.......... 11, 130

Sammy Swamp............................... 49, 135

Sampit River

Sand dunes, occurrence of

Sandy Run, section near.................. 71

Santee Canal, fossils found near........ 79, 80, 144

Santee limestone, character and relations of.- 72-77 description of, by counties.............. 77-82 fossils in, lists of.................. 76-77, 80,82 water in................... 163

Santee River, features of formations exposed along.-. $49,77-78,79,81,153$

Santee River road, exposures along.......... $\quad 139$

Savannah Creek............................. 138

Savannah River, fossils collected along..... 01,102 general relations of................... 11-12, 130 sections along...-.-.-. 24-25, 104-109, pl. 16, B

Scape Oer Swamp..................... 12, 134, 139

Schultzes Lake............................ 87 
Scotchmans Bluff.

Scott Lake.

Sea, fuctuations in level of

$5-6,13-14,130,154$

Sea islands, occurrence of ............ 5-8, pls. 4-7 Beashore, shifting of, causes and effects of ... 3-9, 13-14, 154-157, pls. 3-10, 17

Seivern 13-14, 154-157, pls. $3-10,17$

Selma chalk, correlation of -. 16

Senn farm.

Shark River m

Shiloh-I ynchburg road 121-122

Shoal River formation, correlation of....-...- $\quad 100$

Shore line, shifting of, causes and effects of.- 3-9, 13-14, 154-157, pls. 3-10, 17

Silver, absence of ............................. 159 Silver Bluff road at intersection of Williston road. 93-94

Simmons Bluff, section at

152

Sisters Ferry, section at . . . . .

Sloan, Earle, quoted.... 4, 41,75,78, 112, 113-114, 115

Smith, L. L., quoted... 10

Smithboro, section near....................... $\quad 147$

Smiths Mills

Snow Hill member, character and relations of

fossils in

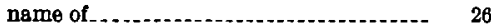

Society Hill, exposures near.................. 22, 133

Solomons Crossroads......................... 137

Solomons Store-_..... 137

Sperrow Swamp, exposures on....... 36, 121, 134, 141

Spring Grove Creok

Stateburg-.................................. $\quad 51$

Stokes Bridge................ 86

Stones Landing......................... 35

Stratigraphy of the area..................... 14-154

Strawberry Ferry.......................... 84

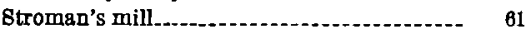

Structure of the area...................... 158-159

Sucarnoochee clay, correlation of

Bugar Loaf Mountain.................... 20-21

Summerville, log of oil-prospecting well at.. 177

Sumter, sections near........................ 135

Sumter beds, use of name

Sumter County, formations in ............ 22, $31-32,50-51,121-122,135,139-140$

ground water in 186-187

well records.

187

Sunderland formation, character and relations of

description of, by counties............. 136-143

water in

Sunderland terrace, features of............... \& $8-9$

Sunderland time, land and sea in.......... pl. 8

Suttons.................................... 44-45, 148

Suwanee limestone, correlation of ........... 97

Sycamore........................................... 137

$\mathbf{T}$

Talbot formation, character and relations of -

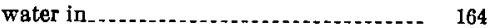

Talbot terrace, features of.................. 7

Talbot time, Iand and sea in

Tallahatta formation, correlation of......... 40
Page

Tampa limestone, correlation of............- 100

Target Swamp .

Tates Landing .............................. 81

Taw Caw Creek.............................. 139

Tearcoat Branch.......................... 139

Terrace plain, use of term .................... 6

Terraces. See Coastal terraces.

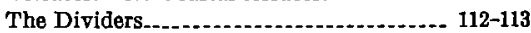

The Grove............................. 129, 130

Tilly Lake.......................... 39, 126

Timmonsville........................... 141

Timmonsville Road....................... 121

Tindall's mill $\ldots . . . . . . . . . . . . . . . . . . . . . . . . . . \quad 49$

Tinker Creek, sections and fossils on ........ 57-58

Tinton sand member, correlation of ....... 16

Tippah sandstone member, correlation of...- $\quad 40$

Tivola tongue of Ocala limestone, correlation of

Tobys Bluffi................................ 111-112

Todds Ferry . . . ........................... 127

Tomb Field Gully, sections in and near..... 69-70

Tombigbee sand member, correlation of..... 16

Toms Creek

Topsaw Landing ...... 38

Treadway Bridge_........... 94

Trent marl, correlation of ................ 100

Triassic period, conditions during

Trinity Church.............................. $\quad 139$

Tuomey, Michael, quoted...... 36, 122, 125, 152-153

Tuomey, exposure near...................... $\quad 135$

Turritella alticostata zone, correlation of.....- 100

Tuscahoma sand, correlation of............. 40

Tuscaloosa formation, character and relations of ....... 15, 16-19, pls. 11, 12, $A, 13, A$

description of, by counties.............. 19-25

fossils in, list of

water in

U

Upper Black Mingo, use of name

Upper Browns Ferry, section at.............. 38

Upper Cretaceous series, correlation of ...... 15-16

description of

general features of ........ 15

Upper Cretaceous time, conditions during 154-155

Upper Pee Dee phase, use of name......... 116

Upper Warley Hill marl, use of name...... 71

Utsey Bluff.................................... 138

\section{V}

Vances Ferry -......... 81

Vicksburg group, correlation of ............. 96-97

Vincentown sand, correlation of ............. 40

\section{W}

Waccamaw formation, character and relations

$$
\text { of - }
$$

description of, by counties............. 125-130

fossils in, lists of ................... 125, 127-129

water in

Waccamaw River, general features of ......- 12 sections along -.................. 39, 126-127, 152

Wadboo Swamp......................... 13,84

Wadmalaw phase, use of name............. 151

Walterboro, exposures near................. 143

$\log$ of well at........................ 174 


\begin{tabular}{|c|c|}
\hline Pame & Page \\
\hline 39 & Wilson. 48 \\
\hline Varley Hill, sections near & Wind, influence of, on topography........ $3,5,7,11$ \\
\hline Varley Hill phase, type locality of & Windy Hill........ 39 \\
\hline use of name........ $55,81,85,89,116$ & Winona sandstone member, correlation of ..- \\
\hline Vater. See Ground water. & Wire Road, exposures on \\
\hline ations of._....... 11, 130 & Iy clay, correlation of \\
\hline$-32,50-51$, pl. $13, A$ & odford, section near. \\
\hline & Crossrodos......... \\
\hline 16 & Woodstock \\
\hline $\begin{array}{l}\text { of Cooper River, exposures } \\
\text { ong }\end{array}$ & $\begin{array}{r}\text { Woodstock greensa } \\
\text { tion of. }\end{array}$ \\
\hline - & 49 \\
\hline (n) & 139 \\
\hline on, character and relations & Wyboo Swamp, section on $\ldots \ldots \ldots \ldots$ 49, 78-79 \\
\hline nties........ 143 & - \\
\hline 164 & $38,127-128$ \\
\hline f.............. 8 & 40 \\
\hline in & $129-130$ \\
\hline (n) 130 & 40 \\
\hline lations in & 100 \\
\hline $44-47,77-78,148$ & 152 \\
\hline 187-188 & rktown formation, correlation of ...... \\
\hline 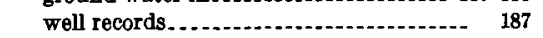 & \\
\hline & \\
\hline 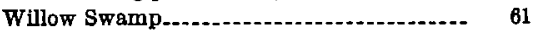 & uglodon beds, use of name \\
\hline
\end{tabular}





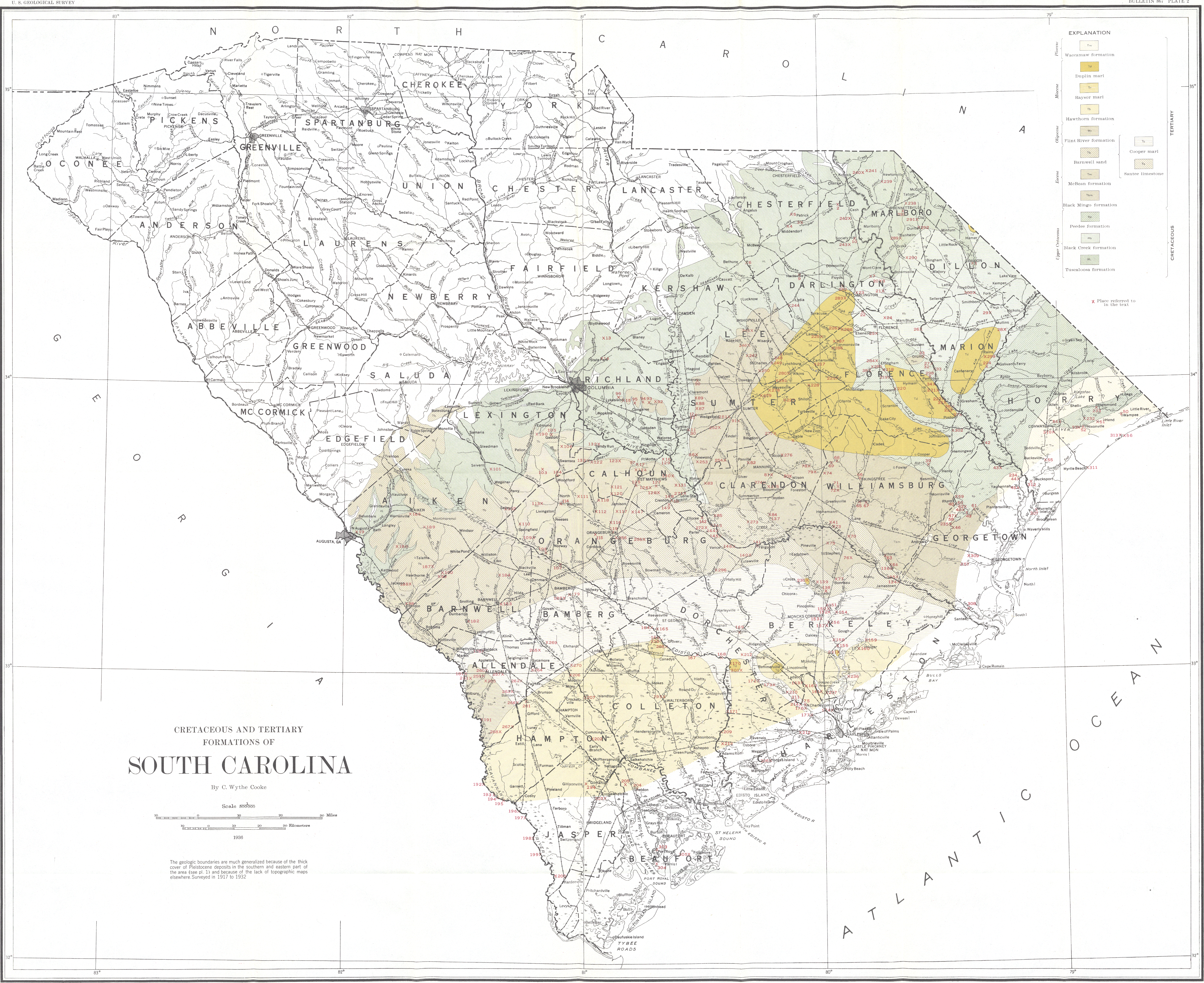


